\title{
Cretaceous Actaeonellid Gastropods from the Western Hemisphere
}

GEOLOGICAL SURVEY PROFESSIONAL PAPER 1304

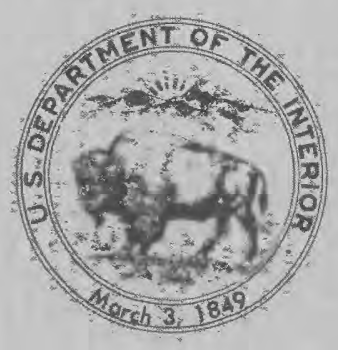




\section{Cretaceous Actaeonellid Gastropods from the Western Hemisphere}

By NORMAN F. SOHL and HEINZ A. KOLLMANN

G E O L O G I A L S UR VEY PROFES IONALA P PER 1304

$A$ description of 28 species of

actaeonellid gastropods, with a discussion

of the evolution, life habits, ecology,

and Cretaceous world distribution of

the family

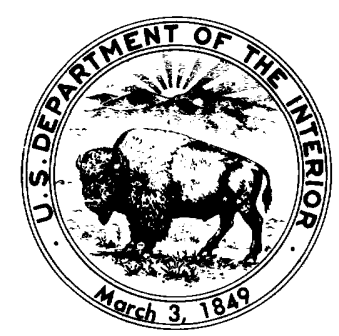

UNITED STATES GOVERNMENT PRINTING OFFICE, WASHINGTON: 1985 


\section{DEPARTMENT OF THE INTERIOR}

WILLIAM P. CLARK, Secretary

\section{U.S. GEOLOGICAL SURVEY}

Dallas L. Peck, Director

Library of Congress Cataloging in Publication Data

Sohl, Norman Frederick, 1924-

Cretaceous actaeonellid gastropods from the Western Hemisphere.

(Geological Survey professional paper ; 1304)

Bibliography: $p$.

Includes index.

Supt. of Docs. no.: I 19.6:1304 $\begin{array}{llllll}\text { 1. Actaeonellidae. } & \text { 2. Paleontology-Cretaceous. } & \text { 3. Paleontology-America. } & \text { I. Kollmann, Heinz A. II. Title. III. Series. } \\ \text { QE809.A18S63 } & 1984 & 564^{\prime} .37 & 83-600250 & & \end{array}$

For sale by the Distribution Branch, U.S. Geological Survey, 604 South Pickett Street, Alexandria, VA 22304 


\section{CONTENTS}

\begin{tabular}{|c|c|c|c|}
\hline & Page & & Page \\
\hline bstract & 1 & Distribution and diversity & \\
\hline troduction & 1 & Evolution of the Actaeonellidae- & 20 \\
\hline Acknowledgments - & 2 & Stratigraphic summary of Western Hemisphere actaeonellid & \\
\hline eflections of soft parts on the actaeonellid shell -_- & 2 & occurrence -_____________________________ & 22 \\
\hline Columellar retractor muscles - & 2 & Early Cretaceous record-- & 24 \\
\hline Character of the mantle edge- & 2 & Late Cretaceous record--- & 24 \\
\hline Musculature of the head-foot mass & 4 & Locality register & 35 \\
\hline Exhalant area-_-_. & 4 & Systematic paleontology & 46 \\
\hline Ecology - - & 4 & Catalogue of actaeonellid species- & 74 \\
\hline Life mode- & 4 & Genera and species excluded from the Actaeonellidae - & 87 \\
\hline Substrate preference - & 6 & References cited --_- & 90 \\
\hline Salinity tolerance - & 7 & Index-_-_-_-_- & 97 \\
\hline Early ontogeny and dispersal potential of ac & 9 & & \\
\hline
\end{tabular}

\section{ILLUSTRATIONS}

[Plates follow index]

Plate 1. Polished section of oriented rock surface from roadcut, Erath County, Tex.

2. Trochactaeon, Actaeonella

3-16. Trochactaeon

17. Actaeonella, Trochactaeon

18-23. Actaeonella

Figure 1. Morphologic features of the actaeonellids

2. Postulated salinity ranges for various Cretaceous faunal assemblages in which actaeonellid gastropods occur _-_____-_ 8

3-4. Histograms of-

3. Species diversity of the subgenera of Trochactaeon during the Cretaceous -

4. Actaeonella species diversity during the Cretaceous-

5-9. Occurrence of Trochactaeon-

5. During the Barremian

6. During the Aptian and Albian

7. During the Cenomanian and early Turonia

8. During the late Turonian to Santonian

9. During the Campanian and Maastrichtian

10-13. Occurrence of Actaeonella-

10. During the Aptian and Albian

11. During the Cenomanian and early Turonian

12. During the late Turonian to Santonian -

13. During the Campanian and Maastrichtian -__

14. Phylogeny of the Actaeonellidae as presented by three previous authors-_- 21

15. Proposed phylogeny of the Actaeonellidae -

16. Correlation of middle Cretaceous formations of Puerto Rico and Texas -

17-18. Correlation of the Upper Cretaceous rocks of-

17. Puerto Rico

18. Central and western Jamaica-_-

19. Stratigraphic ranges of the Western Hemisphere actaeonellid gastropod species - 
Figures 20-25. Index maps showing-

20. Collection localities in Puerto Rico-_-

21. Collection localities and occurrence of Cretaceous rocks in Jamaica -__

22. Collection localities and areas of Cretaceous outcrop in Cuba -

23. Collection localities in Texas and New Mexico -

24. Collection localities in Mexico and Guatemala _-_

25. Collection localities in California -

26-45. Scatter diagrams comparing height with width among selected specimens of-

26. Trochactaeon (Trochactaeon) woodsi (Rennie)

27. Trochactaeon (Trochactaeon) packardi(Anderson)

28. Trochactaeon (Neocylindrites) cumminsi Stanton

29. Trochactaeon (Neocylindrites) nelsoni Sohl and Kollmann, n. sp.

30. Trochactaeon (Mexicotrochactaeon) conformis (Böse)

31. Trochactaeon (Mexicotrochactaeon) burckhardti (Böse)

32. Trochactaeon (Mexicotrochactaeon) wrighti Sohl and Kollmann, n. sp.

33. Trochactaeon (Mexicotrochactaeon) palmeri Sohl and Kollmann, n. sp.

34. Trochactaeon (Mexicotrochactaeon) granthamensis Sohl and Kollmann, n. sp.

35. Trochactaeon (Mexicotrochactaeon) rossi Sohl and Kollmann, n. sp.

36. Actaeonella pecosensis Stanton

37. Actaeonella delgadoi Choffat

38. Actaeonella browni Sohl and Kollmann, n. sp.

39. Actaeonella borneensis Nuttall and Leong

40. Actaeonella duckettsensis Sohl and Kollmann, n. sp.

41. Actaeonella jicarensis Sohl and Kollmann, n. sp.

42. Actaeonella coquiensis Sohl and Kollmann, n. sp.

43. Actaeonella marchmontensis Sohl and Kollmann, n. sp.

44. Actaeonella briggsi Sohl and Kollmann, n. sp.

45. Actaeonella cubensis Sohl and Kollmann, n. sp.

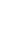
1

34 49 52 53 55 57 58 59 


\title{
CRETACEOUS ACTAEONELLID GASTROPODS FROM THE WESTERN HEMISPHERE
}

\author{
By Norman F. SoHl and Heinz A. KollmanN ${ }^{1}$
}

\begin{abstract}
Actaeonellid gastropods constitute one family of the cephalaspidean opisthobranch superfamily Acteonacea. During the Cretaceous they were one of the most common biotic elements in the shallow warmwater faunas of the Tethyan Realm. They were common associates of the rudist framework ("reef") tracts that in the Western Hemisphere ranged throughout the Mexico-Central America-Antillean-Gulf Coast region. Maps are presented showing the worldwide distribution of these gastropods during five time intervals of the Cretaceous Period. Their greatest latitudinal extent was during Albian to Cenomanian times; subsequently, they were restricted to narrowed Tethyan and marginal Tethyan areas. One paleolatitudinal anomalous occurrence in Alaska may be related to current concepts of suspect allocthonous terranes.
\end{abstract}

Actaeonellids show a progressive increase in numbers of species from their first appearance in the Barremian Stage to a high in the late Turonian to Santonian interval. Subsequently, their diversity declined during the Campanian and Maastrichtian, and, like their common associates the nerineid gastropods and rudist bivalves, they became extinct at the end of the Cretaceous. Their record in the Western Hemisphere is at some variance with that of actaeonellids in the rest of the world. During the latest Cretaceous, they maintained a high level of diversity in the Caribbean to Mexico region and showed a tendency toward taxonomic provincialism. This latter feature is demonstrated by the appearance in the Maastrichtian of species of Actaeonella having only two instead of three columellar plications and by the presence of an endemic subgenus Trochactaeon (Mexicotrochactaeon) in rocks of Coniacian to Maastrichtian Age.

Evidence is presented to indicate that actaeonellids possessed two distinct adult life habits. At postlarval metamorphosis, both Actaeonella and Trochactaeon were initially epifaunal. Subsequently, Actaeonella assumed an infaunal habit, whereas Trochactaeon remained epifaunal to adulthood. In addition, studies of associated biotic elements suggest that the two genera possessed different salinity tolerance; Trochactaeon (Trochactaeon) had the broader range of tolerance, ranging well into environments of low salinity.

Only two genera, Actaeonella and Trochactaeon, are recognized as present in the Western Hemisphere. Trochactaeon is subdivided as follows: the nominate subgenus, $T$. (Neocylindrites), T. (Sevanella), and $T$. (Mexicotrochactaeon). Of these, only $T$. (Sevanella) lacks representation in this hemisphere. The earliest occurrences in the Western Hemisphere of species of Actaeonella and Trochactaeon (Neocylindrites) are in rocks of Albian Age. The reason for their absence in rocks of suitable pre-Albian facies is unknown. In total, 14

'Naturhistorisches Museum in Wien, Geologisch-Paläontologische Abteilung, Vienna, Austria. species of Trochactaeon are described, seven of them new. In addition, three more species are distinguished but not formally proposed because of insufficient material. Actaeonella is represented by 14 described species (nine new), and one species is distinguished but unnamed because of inadequate information.

A final section of this report consists of a catalogue of the described Cretaceous species of actaeonellids. This listing is the data base used for the construction of the maps of distribution and the histograms of diversity with time.

\section{INTRODUCTION}

Knowledge of the Cretaceous molluscan faunas of the Western Hemisphere is very unequal with respect to geographic areas, biologic group, and stratigraphic interval. For example, mollusks of the late Late Cretaceous of the Coastal Plains of eastern North America are quite well documented, whereas those of the Caribbean region to the immediate south are, overall, poorly known. In the Caribbean region, only one molluscan group, the rudist bivalves, is at all reasonably known. In general, knowledge of the Western Hemisphere faunas of the Cretaceous temperate marine seas is much greater than that of faunas of the Tethyan (warm-water tropical) biogeographic province. The present work is intended to give detailed information about the Actaeonellidae, one of the major molluscan groups distributed throughout the warm-water Tethyan Realm.

The Actaeonellidae constitute but one family of the cephalaspidean opisthobranch superfamily Acteonacea. As here conceived, they were restricted to the Cretaceous Period. Their extinction at the end of the Cretaceous coincided with that of the rudist bivalves, nerineid gastropods, and other major faunal associates of the Tethyan warm-water biota. Although the actaeonellids were of low generic diversity, the almost 200 species recorded in the catalogue section of this report show that though their geologic history was relatively short, they were a very viable group.

The actaeonellid gastropod fossils described herein lived in the tropical Tethyan and marginal Tethyan 
seas. They were common faunal elements associated with the Cretaceous carbonate platform communities most noted for their abundance of rudist bivalve framework-building organisms (Kauffman and Sohl, 1974). In many parts of the Tethyan Realm they were sufficiently abundant to constitute principal constituents of rock bodies (Kollmann, 1965, fig. 23, Sohl, 1971, fig. 1). In the Eastern Hemisphere, their taxonomy and distribution has received considerable attention by paleontologists (Kollmann, 1967; Hacobjan, 1972, 1976, Djalilov, 1972; Pchelintsev, 1953); in the Western Hemisphere, however, no such synthesis has previously been attempted for the group. One major reason for this lack of knowledge has been the reconnaissance level of geologic work in much of the region that contains outcrops of Tethyan-belt Cretaceous rocks. In recent years, knowledge has increased because of increased interest in the geology of the outcropping Cretaceous rocks of Mexico, Central America, and the Caribbean area. This interest has been engendered in part by the common occurrence of hydrocarbon resources in rudist bivalve framework structures and associated rocks and in part by the role the Caribbean region plays in global plate-tectonic theory.

Much of the material that forms the basis for this paper was collected by Sohl (1956-1974) during a U.S. Geological Survey cooperative program with the Commonwealth of Puerto Rico. The aim of this program was to provide total geologic mapping of that island. Concurrent studies were carried on by Sohl and others on the Cretaceous rocks of Jamaica because of the presence there of less structurally disturbed sequences that afforded better opportunity to establish stratigraphic ranges of taxa. The remainder of the material described has been assembled from collections housed at various institutions throughout the United States.

\section{ACKNOWLEDGMENTS}

Many individuals and institutions facilitated our work by loan of specimens contained in their collections or by providing other tangible aid. The Smithsonian Institution is due special thanks for support of Kollmann during his tenure as a Postdoctoral Fellow. Christopher Durden of the Texas Memorial Museum in Austin; Peter A. Rodda of the California Academy of Sciences, San Francisco; the late Katherine Van Winkle Palmer of the Paleontological Research Institute at Ithaca, N.Y.; and Keith Young of the University of Texas at Austin arranged for loans of specimens housed at their respective institutions. Ted Robinson of the University of the West Indies in Kingston, Jamaica, provided Sohl with maps, hospitality, and aid in shipping collections from that island. Anthony G. Coates,
George Washington University, Washington, D.C.; J. E. Hazel, U.S. Geological Survey, Reston, Va.; and E. G. Kauffman, University of Colorado, Boulder, aided in collection of fossils and in pertinent discussion of stratigraphic problems in the field and office.

\section{REFLECTIONS OF SOFT PARTS ON THE ACTAEONELLID SHELL}

Certain anatomical features of the Actaeonellidae and their relative placement can be deduced from shell characters.

\section{COLUMELLAR RETRACTOR MUSCLES}

Longitudinal grooves on the upper quarter of the parietal area of the body whorl of Trochactaeon have been described by Kollmann (1967). They occur about one-half of a whorl behind the aperture and in some species may be divided by a series of small ridges. We note herein similar structures in Mexicotrochactaeon. These longitudinal grooves are depressions of the hypostracum, marking the position where soft parts adhered closely to the shell. Positioning of this longitudinal band of grooves on the body whorl well behind the aperture suggests that this feature marks the position of the columellar retractor muscles. The work of Fretter and Graham (1954) supports this interpretation. They figured a specimen of the cephalaspidean Actaeon tornatilis with the shell removed, which shows the columellar muscle occurring as a band on the upper part of the whorls. Lemche (1956) recorded muscles in the same location on Cylichna. His anatomic investigations, however, suggest that these muscles function as retractors of the mantle.

\section{CHARACTER OF THE MANTLE EDGE}

The form of the aperture provides some information on the nature of the mantle margin. For example, in $T$. (Trochactaeon), T. (Neocylindrites), and T. (Mexicotrochactaeon), a parietal inductura extends over the body-whorl surface outside the aperture and over the columella, with a margin bending anteriorly toward the concave basal lip. The boundaries of this inductura indicate the limits of the extension of the mantle outside the aperture (fig. $1 \mathrm{C}$ ). In contrast, no inductura has been observed on shells of Actaeonella. The basal lip of Actaeonella is somewhat reflected (pl. 19, fig. 8), suggesting a thickening of the mantle, which may have served as a device against intrusion of sediment into the mantle cavity. 

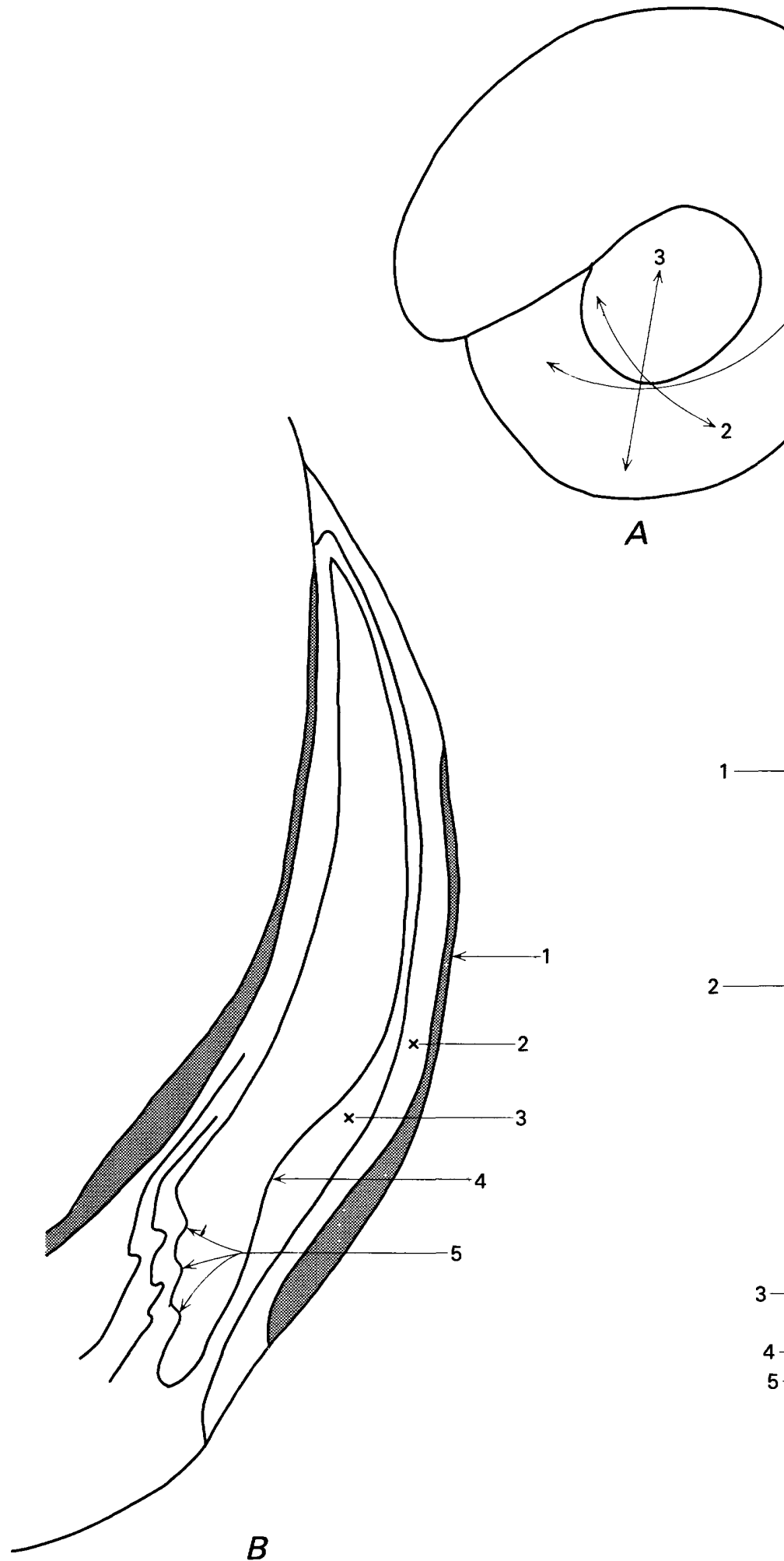


\section{MUSCULATURE OF THE HEAD-FOOT MASS}

All actaeonellids possess columellar plaits (figs. $1 B$ and $1 C$ ), but strength and extent of both the plaits and the excavated areas between plaits may vary. The upper, or posteriormost, columellar plait invariably extends out of the aperture onto the body-whorl surface. The second or next anterior plait normally terminates at the aperture. That is, it ends on the columellar surface precisely at the intersection of the outer lip and apertural margin plane. When present, a third and anteriormost plait never reaches the aperture margin plane. The plaits themselves represent the position of hypostracum crests that separate parallel muscle bands. The differing lengths of the plaits, plus the slight difference in their angle of inclination relative to the shell axis, suggest that the muscle bands served different functions relative to the head-foot mass. The interplait areas trend in an anterior direction overall. The incision above the first, or posterior, columellar plait, is the most strongly depressed. In Actaeonella, $T$. (Neocylindrites), and T. (Trochactaeon), it is a rather narrow incision, but in $T$. (Mexicotrochactaeon) the incision is broad and terminated posteriorly by a parietal plait. According to the trend of the incision, the muscle must have had a basic horizontal action function (fig. $1 A$ ). The incision between the posterior and second plait trends more toward the left side of the shell as viewed from the anterior. The incision between the second and third, or anteriormost, plait trends downward and to the right (fig. $1 A$ ). The fact that the upper (posteriormost) muscle-insertion area extends outside the aperture suggests that the soft parts could not be completely retracted. When these fossils are compared with some living neogastropods having columellar plaits (Ponder, 1973), one may postulate that the actaeonellid interplait muscle bands were used to control head and foot movements during burrowing or ploughing through the substrate.

\section{EXHALANT AREA}

Many authors (Cossmann, 1895; Delpey, 1939; Termier and Termier, 1952; Pokorny, 1959; and Kollmann, 1967) have pointed out the importance of the structure of the posterior aperture margin of the actaeonillid shell for interpreting life habits of the group. On shells of Trochactaeon, the posterior edge of the outer lip bends back in a sinus curve for approximately one-sixth of a whorl before it becomes attached to the penultimate whorl. This posterior slit is closed at the attachment point by a subsutural ramp that is formed by hypostracum layers. This suggests that shell material was deposited by the mantle surface and not at the mantle edge in the vicinity of the sutural ramp.
The posterior sinus is in a position analogous to the right posterior end of the mantle chamber, an area that probably also bore the anal aperture. Obviously, the posterior sinus (fig. 1c) marks the position where currents carrying fecal wastes were extruded. This interpretation is consistent with similar structures and functions in such living Cephalaspidae as Actaeon, Philine, Scaphander (Fretter and Graham, 1954), and Cylichna (Lemche, 1956), as well as in certain neogastropod groups that possess columellar plaits and have a burrowing habit (Ponder, 1973).

\section{ECOLOGY}

Actaeonellids were common members of Cretaceous faunal assemblages that are widely distributed in a belt paralleling the Equator, a belt commonly called the Tethyan province or realm (Sohl, 1971, and figs. 5-13). The actaeonellid pattern of distribution is similar not only to that of such other gastropods as the nerineids Trajanella, Pileolus, and Discotectus but also to that of the corals that Beauvais and Beauvais (1974) have termed "building corals" and to that of the rudist bivalve framework builders (Kauffmann and Sohl, 1974). These faunal associations have long been considered to delimit a tropical biotic realm. The distribution shown by some actaeonellids suggests that they may have had a wider temperature tolerance than others. For example, node-bearing forms of Trochactaeon are found not only in normal warm-water assemblages in the Caribbean and in Transcaucasian Armenia but also from both northern and southern extremes of actaeonellid distribution. The noded species $T$. (Trochactaeon) woodsi (Rennie) occurs in the Cretaceous of Pondoland, South Africa, associated with a fauna otherwise similar in composition to that of the North American Ripley Formation that Sohl (1964) judged as a temperate fauna. North of the Tethyan belt, noded species such as T. (Trochactaeon) beyrichi (Drescher, 1863) occur in Coniacian-Age rocks in Poland and Czechoslovakia (Frič, 1911; Andert, 1934), where the associated fauna contains only one other species, Nerinea bicincta Bronn of Andert (1934), of presumably warm-water affinities.

\section{LIFE MODE}

Direct evidence of life mode of Actaeonella is found in an occurrence near Morgan Mill in Erath County, Tex., mentioned in the section on substrate preference and illustrated on plate 1 . In the lower part of the sectioned slab is a bioturbated zone about $6 \mathrm{~cm}$ thick. Parts of both vertical and diagonal burrows having a circular 
cross section can be recognized in this zone. Cut sections occasionally intercept specimens of Actaeonella within the burrows (see arrow "A" on pl. 1). The specimens sectioned are oriented with the anterior part of the shell inclined downward. Both the form of the burrows and orientation of the shells therein agrees well with Fretter and Graham's (1954) observations of the burrowing behavior of Actaeon tornatilis (Linne). These opisthobranch gastropods begin burrowing into the substrate in a vertical or diagonal direction. After a few centimeters of penetration they turn to a lateral or horizontal mode of travel and then eventually move back toward the sediment surface. During burrowing, the head lobes and pedal gland are pressed against the sand; secretions then agglutinate the sand particles and cement the burrows, preventing collapse as the animal moves on.

The close similarity of the burrows of Actaeonella and Actaeon and the similar orientation of the shells of both genera within the burrows is strong evidence for postulating an infaunal habit for Actaeonella. In addition, the general shell form of Actaeonella and T. (Neocylindrites) suggests an infaunal life habit. Not only does the spindle-shaped outline suggest such a habit, but the funnel-shaped posterior siphon in Actaeonella and the sutural slit of $T$. (Neocylindrites) are analogous to similar sanitary devices in other infaunal gastropods (Kollmann and Yochelson, 1976). Ponder (1973) has pointed out that infaunal neogastropods have both a similar siphonal canal system and columellar plaits.

Although Trochactaeon possesses a posterior siphonal slit, other characters suggest that it had a life mode differing from that of Actaeonella. In contrast to the smooth streamlined spindle-shaped shells of Actaeonella, Trochactaeon has a relatively high spire and a proportionally broad shell; some species even bear coarse nodes on the whorl shoulder. Overall, these characters do not appear to be conducive to an infaunal habit, but infaunal habit is found in other living snails of similar form. The infaunal tonnacean Cassis madagascarensis spinella Clench, is large, possesses noded whorls, and superficially resembles Trochactaeon. As Moore (1956) noted, this species plows through the substrate in search of its prey, the echinoid Plagiobrissus. Though grossly similar to Trochactaeon, Cassis differs significantly in its widely expanded aperture that reflects a great broad muscular foot, a feature not present in Trochactaeon.

The great variability in shell character within individual species of Trochactaeon may also suggest a primarily epifaunal existence. This variability is especially well expressed in proportional height of the spire and in maximum diameter of the body whorl compared with total height. Such variability far exceeds any comparable variation in Actaeonella. The work of Levinton (1973) and others provides an explanation. In studying extant bivalves, Levinton has demonstrated that below the sediment-water interface, temperature and salinity variations are at a minimum. Similarly, as water depths increase, there is a correlative increase in environmental stability. Levinton concluded that species living in variable environmental settings tended toward polymorphism, whereas those living in the more stable situations tended toward isomorphism. Struhsaker (1968) has demonstrated a similar relationship in the Gastropoda. She found that polymorphic species of Littorina were better adapted to withstand environmental extremes than were isomorphic species. Thus, Actaeonella fits the model of an isomorphic form living in a stable situation such as that provided by an infaunal habit, in contrast to the polymorphic Trochactaeon.

We can see no direct correlation between a gastropod having a proportionally higher spire or greater maximum diameter and the ability to withstand greater environmental variation. Thus, we assume that these characters were genetically linked with other characters that together provided some advantage.

Other lines of evidence suggest that Trochactaeon was dominantly an epifaunal dweller. For example, many shells show the effects of mechanical wear and either repair of shell or internal secondary shell deposition (pl. 15, fig. 8). In many shells, numerous additional shell layers are deposited in the spire and internally separate the body or later whorls from those formed earliest. Kollmann (1967) has noted that the hypostracum shell layers are exposed near the suture. These layers are not as resistant as those of the ostracum and are the first affected by mechanical wear such as wave action. Thus, probably in response to irritation of the mantle, secondary lamellae were deposited in the posterior part of the whorl (pl. 15, fig. 9). The fact that apical whorls could be sealed off indicates the ability to withdraw the visceral mass from the earlier parts of the shell, that is, those parts most endangered. Such withdrawal logically could cause a shell-space problem that was not totally alleviated by continued growth. This problem may have been countered by resorbtion of some shell wall and columellar structures (pl. 15, fig. 9 ). Both secondary deposition of lamellae and resorbtion phenomena have been observed in T. (Trochactaeon) but have not been noted in Actaeonella and $T$. (Neocylindrites).

The foregoing lines of evidence suggest that Trochactaeon lived in shallow, well-agitated water and that if it ever was a dominantly infaunal organism, it became increasingly epifaunal in habit during the Late Cretaceous. Such a view would be consistent with the fact 
that species such as T. (Mexicotrachactaeon) coniformis (Böse), which is one of the stratigraphically youngest species, shows the highest degree of shell polymorphism.

Not all workers accept such a view of the life habits of Trochactaeon. For example, Herm and Schenk (1971) concluded that, on the basis of the proportionally narrow aperture and comparatively large and thick shells, Trochactaeon was not very mobile and possessed a rather stable life position. This interpretation has several weak points. For example, such a sedentary mode would be compatible only with a filter feeding or mucous-string feeding habit. Both these feeding modes are unknown among other opisthobranchs (Purchon, 1968). The closest analogues, the Cephalaspidea, are all collectors of organic detritus. In addition, one may also cite both the Cypraeidae and Conidae as groups that have shells of at least moderate size, possessing a proportionally narrow aperture and yet not being sedentary. Herm and Schenk (1971) have also applied Vogel's (1968) suggestion that the curvature or growth direction of a radiolitid on a gastropod shell in a direction opposite that of the growth direction of the outer lip indicates that it grew upon the shell of a live snail. Among the specimens investigated by Herm and Schenk, 72 percent show radiolitids attached in a fashion consistent with the growth of both rudist and Trochactaeon; 28 percent do not. Fretter and Graham (1954) mentioned that in all cephalapidean gastropods, the shell aperture is to the right of the midline of the shell. Even if the aperture is rather narrow, which, in actaeonellids, it appears to be only when the edge of the outer lip is broken, an empty shell has greater stability relative to overturning on the aperture side. During the growth of a radiolitid that settled upon a dead shell, the probability of rotation or overturning toward the less stable side-that is, opposite the aperture-is highest. Thus, most radiolitids would show a growth direction that Herm and Schenk believe is characteristic for growth on a shell of a living gastropod. Finally, the high concentration of shells at the locality they studied suggests accumulation after death. If this is true, such a shell pavement would provide a prime hard substrate for settlement of rudist spat and the subsequent growth of radiolitids. In summary, we do not see that the evidence of narrow aperture, size, and, rarely, radiolitid attachment provides a compelling case for interpreting Trochactaeon as a sedentary epifaunal gastropod.

On the basis of the evidence and interpretations presented above, we maintain that Actonaeonella and $T$. (Neocylindrites) were infaunal burrowers much in the fashion of Actaeon tornatilis and that $T$. (Trochactaeon) and $T$. (Mexicotrochactaeon) were primarily epifaunal vagrant benthos elements.

\section{SUBSTRATE PREFERENGE}

Direct evidence for substrate preference of actaeonellids is rare. Most such evidence points to a preference for finer grained bottom sediments. For example, in Cretaceous exposures in roadcuts immediately northwest of Morgan Mill in Erath County, Tex., Actaeonella sp. was found in living position (pl. 1, fig. 1, and preceding discussion on life habits). The rock is a calcareous, silty fine sand. Turritella is the only associated larger fossil. We interpret the Actaeonella as an infaunal burrower and believe that the Turritella probably paralleled its living counterpart $T$. communis by living apex down in the muddy sand substrate in its filter-feeding mode (Merriam, 1941; Yonge, 1946; Thorsen, 1965; and others). Low-diversity associations of this type are not uncommon today in relation to cephalaspidean opisthobranch gastropods. For example, Parker (1975) has noted that in the Woods Hole, Mass., vicinity, Cylichna oryza (Totten) and Retusa canaliculata (Say) occur together in clayey silt substrates where other gastropods are rare. Similarly, Herm (1977), in his studies on the faunal assemblages of the northern calcareous Alps, has emphasized the low diversity in his "Trochactaeon association." These "associations" are divided first into a RadiolitesTrochactaeon group occurring in a well-sorted, mediumgrained sand that is interpreted as a high-energy beach deposit. Laterally, these deposits grade into "Trochactaeon sands," in which shells are concentrated by wave action. Herm also described obviously autochthonous Trochactaeon from poorly sorted silty sands that contain beds of pebbles, a deposit that he interprets as tidal flat.

Actaeonellid-dominated Cretaceous deposits are sporadic throughout the Caribbean Antilles and in Central America. In general, these occurrences parallel those from Europe described above. Actaeonella occurs in some deposits to the virtual exclusion of other molluscan taxa. Chubb (1959, p. 743), in describing the uppermost sandy limestone of the Nuevo beds of Chiapas, Mexico, stated that " $A$. cf. laevis occurs in incredible profusion in all exposures; other fossils are generally comparatively rare." These Actaeonella are referred to A. borneensis herein (pl. 19, figs. 16-21) and occur in a matrix of fine calcareous quartz sand containing large Foraminifera, rounded concentric-growth algal spheres (5 $\mathrm{mm}$ diameter), and echinoid debris. The large $(8 \mathrm{~cm})$ slender actaeonellids are well preserved, showing little evidence of transport. The combination of biotic elements suggests a shallow nearshore deposit of moderate energy level. Another Actaeonelladominated assemblage from the Melones Limestone of southwestern Puerto Rico has been figured by Sohl 
(1971, fig. 1). The actaeonellas are in a calcareous tuffaceous limestone containing abundant angular coarse clasts of volcanic rocks and generally finer rounded bioclastic fragments of echinoids and rudists.

Not all Actaeonella occur in sand. For example, Actaeonella jicarensis Sohl and Kollmann, is found in a muddy limestone in Puerto Rico (Smith and others, 1968, p. G2), in which tall slender nerineids and Turritella are the other dominant species. Nerineids are usually the most abundant, but locally Actaeonella sp. may dominate.

$T$. (Trochactaeon) woodsi (Rennie), a noded form, in its occurrences in Puerto Rico is found both in a mechanically concentrated bed at locality 39 and as the dominant constituent in limestone at localities 41 and 47 (fig. 20). The latter limestones indicate that the substrate was basically a lime mud, but allocthonous rounded coarser shell debris is not uncommon.

$T$. (Mexicotrochactaeon) is most common in shaly intervals interbedded with rudist-dominated limestones in such sections as that along the Rio Minho in the Central Inlier of Jamaica (localities 64 and 65, fig. 21). The matrix is generally a silty clay containing fine shell and plant fragments. The associated fauna is moderately diverse, including a few species of infaunal bivalves, the thin-walled small rudist Distefenella, and trochiform and strombid gastropods. Kauffman and Sohl (1974) have viewed these as lagoonal associations.

The above observations can only vaguely suggest that Trochactaeon and its allies preferred calcareous muds, whereas Actaeonella was more commonly associated with somewhat coarser clastic sediments.

\section{SALINITY TOLERANCE}

The well-studied Upper Cretaceous sequences in the Alps provide us with the best information relative to salinity tolerance of the actaeonellids. Earlier authors (Zittel, 1881-1885; Zapfe, 1937; Pokorny, 1959) usually considered the fossils to have lived in brackish water. This was suggested to explain the concentrated occurrence of Trochactaeon in the northern calcareous Alps. In addition, these authors considered both Actaeonella and Trochactaeon to belong to the same genus. On the basis of a comparison of the accompanying fauna, Kollmann (1965), in contrast, demonstrated that Actaeonella and Trochactaeon possessed differing salinity tolerance. Although Kollmann found no suggestion that salinities higher than Polyhalinikum (classification of Remane, 1963, see also fig. 2) could be tolerated, Schenk (1972) demonstrated that both genera could tolerate the higher concentrations of the Euhalinikum. In figure 2, occurrences of Actaeonella, T. (Neocylindrites), and T. (Trochactaeon) have been plotted against
Remane's salinity zones. As indicated on this figure, $T$. (Neocylindrites) and Actaeonella do not pass into salinity zones below $18 \mathrm{ppm}$. In the Alpine Cretaceous, these two genera occur in association with rudist and coral faunas, which are commonly quite taxonomically diverse. Similar occurrences may be documented from numerous Western Hemisphere localities. Such limitations of distribution support the view that the habitats of $T$. (Neocylindrites) and Actaeonella have a closer affinity than do the habitats of either of them to that of $T$. (Trochactaeon).

T. (Trochactaeon) presumably had a broader salinity tolerance, ranging from Meiomesohalinikum (5-10 ppm) to Euhalinikum (30-40 ppm). The association in shales of Trochactaeon with Glauconia, Neritopsis, Pirenella, and Pseudomelania led Kollmann (1965) to postulate a low-salinity occurrence. Similar associations are documented elsewhere in the Alps, such as Herm's (1977) Polymesoda-Glauconia association. In addition, similar faunas are found near Dreistaetten in lower Austria and Vorderstoder in upper Austria. The constancy of the composition of these assemblages is strong support for the view that Trochactaeon was a component of many brackish-water faunas.

In many sections, sandstones contain densely packed Trochactaeon shells. In discussion of such occurrences, Nuttall and Leong (1972, p. 6) stated: "It seems likely that many concentrations of shells of one species occur as a result of differential sorting after death. The most acceptable explanation is that actual actaeonellid limestones were formed of current-sorted shells probably in very shallow water." We agree that many such paucispecific occurrences are the result of transport and size sorting. However, some occurrences of Trochactaeondominated, low-diversity assemblages appear to us to represent a biocoenosis. For example, Herm (1977) reported sands containing abundant Trochactaeon of various size grades (growth stages) and associated with a few specimens of the coral Astrocoenia, the gastropod Patella, and the bivalves Pedalion and Tellina. The sands are highly bioturbated by Callianassa, but the assemblage is deemed autochthonous. This sand assemblage grades laterally into other sands that contain size-sorted Trochactaeon. Herm (1977) also recorded Trochactaeon in an assemblage dominated by the bivalve Cucullaea and the gastropod Ampullina. Because rare specimens of Glauconia and Polymesoda are also associated in this assemblage, it is assigned to the Pleiomesohalinikum (10-18 ppm) salinity zone.

Present knowledge of the occurrences of $T$. (Neocylindrites), Actaeonella, T. (Mexicotrochactaeon) and $T$. (Trochactaeon), in the Caribbean region is insufficient to indicate salinity tolerance to the degree indicated for the assemblages discussed above. This insufficient 


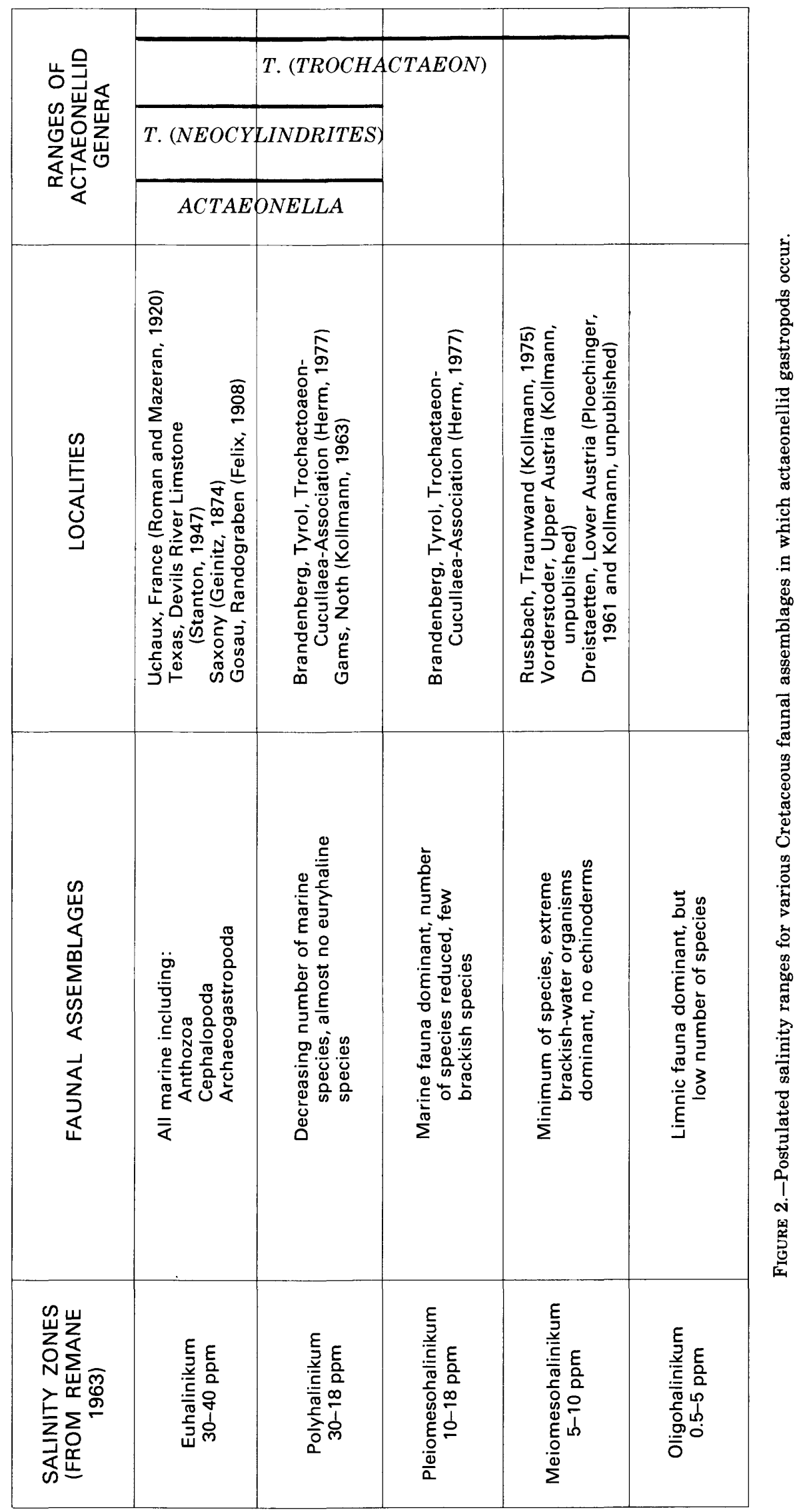


knowledge is primarily due to the lack of study of the molluscan faunas in general in the area and especially to the dearth of quantitative analyses.

\section{EARLY ONTOGENY AND DISPERSAL POTENTIAL OF ACTAEONELLIDS}

Maestrichtian-age shales at several localities in Jamaica have yielded immature actaeonellid specimens that show the character of the protoconch and its relationship to the early teloconch development. These specimens indicate a significant difference in early life history between Actaeonella and Trochactaeon.

In Actaeonella, the early sequence of growth may be seen in the specimen figured on plate 2 , figure 4 . This specimen (USNM 305999) from the "Titanosarcolites limestone" of the Marchmont inlier (locality 97) of Jamaica, although poorly preserved, shows a complete heterostrophic protoconch at the apex together with the initial phase of the teloconch. The protoconch or larval stage has a diameter of $0.24 \mathrm{~mm}$ and is delimited from the teloconch by a narrow incision. On this and a second specimen (pl. 2, fig. 3, USNM 305998) from this locality, one may note that the first three teloconch whorls form a turriculate shell. These whorls are convex sided and show no subsutural ramp. After these three initial whorls, shell geometry changes; whorl overlap increases so rapidly that after one more whorl, most of the teloconch is enveloped. The change from an initial turriculate teloconch stage to later total envelopment is also shown in the illustration (pl. 23, fig. 5) of a section cut through the center of a specimen of Actaeonella cubensis.

The clear distinction between Actaeonella and Trochactaeon is well seen by contrasting figures 3 and 4 with figures 1 and 2 on plate 2 . The two specimens of Trochactaeon (Mexicotrochactaeon) sp. from the Guinea Corn Formation of Jamaica illustrated here show that the protoconch is similarly heterostrophic (see pl. 3, figs. 1-4), and it is clearly separated from the teloconch by an incision. The maximum diameter of the protoconch, however, is $0.18 \mathrm{~mm}$, and the whorls are circular in cross section. The early whorls of the teloconch have the same elongate narrow shape with subsutural ramp as those of the later shell.

The major differences thus indicated between Actaeonella and Trochactaeon early growth stages are:

1. The diameter of the protoconch is larger in specimens of Actaeonella than in Trochactaeon (Mexicotrochactaeon). Kollmann (1967) also found a similar relationship in actaeonellids from Gosau, Austria; the protoconch of $T$. (T.) lamarcki consisted of two volutions having a maximum diam- eter of $0.1 \mathrm{~mm}$, whereas that of A. laevis exceeded $0.2 \mathrm{~mm}$.

2. The early teloconch whorls of Trochactaeon (Mexicotrochactaeon) have a subsutural ramp and are almost exactly like those of the later teloconch. Kollmann (1967) noted the same character for $T$. (Trochactaeon). In contrast, Actaeonella undergoes a two-stage change in shell geometry, first, a change in coiling direction between larval and neanic stages (postprotoconch) and second, a change in overlap of the whorls after the third convex-sided teloconch whorl culminating in an involute shell.

Although the protoconch size differs in Actaeonella and Trochactaeon, it may have little significance. In both genera the ratio between the number of protoconch volutions and the maximum diameter places them in the same category as those prosobranchs having a long to moderately long pelagic larval stage (Shuto, 1974). More information is needed to determine whether protoconch size is consistent in the group, but the distribution of the family during the Cretaceous supports a high larval dispersal capability.

The second noted contrast between Actaeonella and Trachactaeon is more significant. The incision separating protoconch from the teloconch certainly marks the metamorphosis or change from a pelagic life stage to a benthonic life mode for both. We suggest elsewhere that Trochactaeon was epifaunal as an adult, and the outogeny would suggest that this mode was assumed at metamorphosis. By contrast, we have presented evidence that the adult Actaeonella was of infaunal habit. The early teloconch turriculate-form developmental stage, however, may mark a short epifaunal crawling stage that preceded the assumption of the adult infaunal mode that is marked by the adult Actaeonella involute shell form.

\section{DISTRIBUTION AND DIVERSITY}

Figures 3-13, showing species diversity and distribution of the Actaeonellidae, have been derived from the information presented in the accompanying species catalogue. The data are divided into five time categories that to some degree crosscut stage boundaries. These five intervals are: Barremian; Aptian to Albian; Cenomanian to lower Turonian; upper Turonian to Santonian; Campanian to Maastrichtian. We realize that this breakdown into several large time intervals may obscure some important fluctuations in diversity and distribution. This objection is offset by the fact that precise age assignment of many many taxa is suspect. Acceptance of worldwide time equivalency of such 


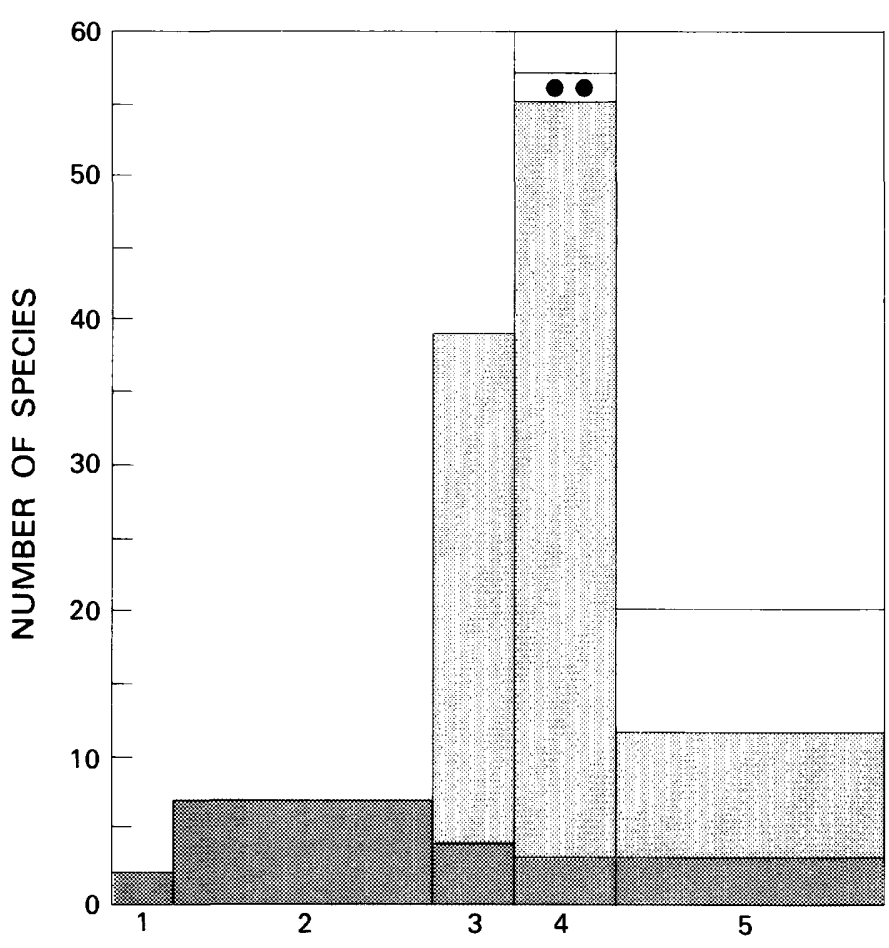

PROPORTIONAL STAGE DURATION IN MILLIONS OF YEARS (M.Y.)

\section{EXPLANATION}

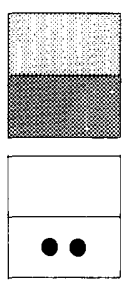

Trochactaeon (Trochactaeon)

Trochactaeon ( Neocylindrites)

Trochactaeon (Mexicotrochactaeon)

Trochactaeon (Sevanella)

FIGURE 3.-Histogram of species diversity among the subgenera of Trochactaeon during the Cretaceous. Width of the columns is proportional to the duration of the stages represented. 1, Barremian (4 m.y.); 2, Aptian-Albian (18 m.y.); 3, Cenomanian-lower Turonian (6 m.y.); 4, upper Turonian-Santonian (7 m.y.); 5, CampanianMaastrichtian (19 m.y.).

assignments is variable, and construction of maps and graphs on that refined a basis would introduce many errors of fact. We have confidence that in accepting these broader time intervals, the minor "noise" fluctuations that the erroneous age assignments would cause is smoothed out, and the concommitant potential for misinterpretation is thus reduced.

Figures 3 and 4 show diversity of Actaeonellidae with time. The patterns of peak diversity for Trochactaeon and Actaeonella show a remarkable consistency. Both show progressive increase in number of species from their first appearances to a high in the late Turonian to Santonian, followed by a decline in Cam-

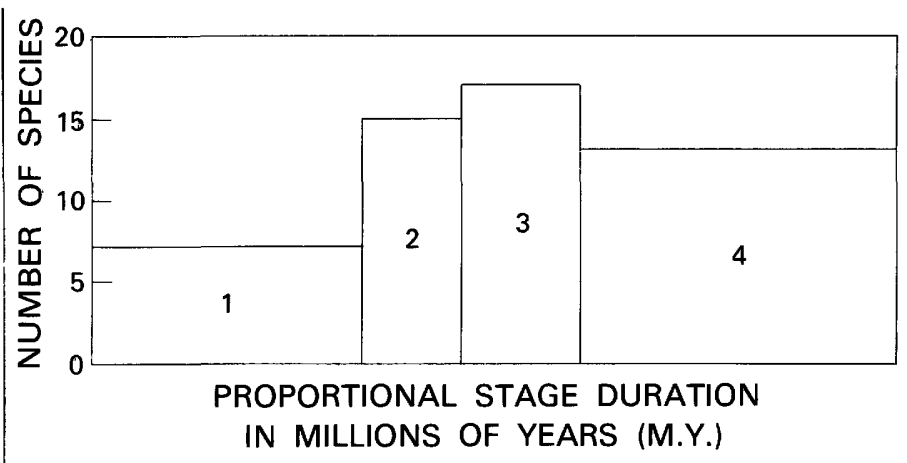

Figure 4.-Histogram of Actaeonella species diversity during the Cretaceous. Width of the columns is proportional to the duration of the stages represented. 1, Aptian-Albian (18 m.y.); 2, CenomanianTuronian (6 m.y.); 3, upper Turonian-Santonian (7 m.y.); 4, Campanian-Maastrichtian (19 m.y.).

panian to Maastrichtian time. This decline, however, does not reach as low a level as that during the virtually equally long Aptian to Albian time. One might argue that the maximum is a reflection of provincial taxonomy, biased by the unusually large numbers of described species from the Transcaucasus (Pchelintsev, 1953, 1954; Hacobjan, 1972; Djalilov, 1972).

If these species from the Transcaucasus are discarded from consideration, a large number of species in the Mediterranean region and elsewhere remain. Thus, although the peaks of diversity might be less accentuated if a more stringent species concept was used, the diversity peaks do seem to have objective validity.

The Cenomanian to Santonian interval also marks a time of wide distribution of Actaeonellidae in the Tethyan realm and in such marginal areas as northern California, Brazil, and East Africa (figs. 7, 8, 11, and 12). The general lack of actaeonellids at this time in the Caribbean is striking. This absence coincides with what Khudoley and Meyerhoff $(1971$, p. 116) consider the major stratigraphic break in the Cretaceous sequence of the Antilles, that is, "Cenomanian or early Turonian below and the Campanian or Maastrichtian above." They envision this as a period of erosion during which few basins received sediments. Where sediments are present, they are deeper water mudstones and volcaniclastic rocks. In summary, this period was one of little or no carbonate-platform sedimentation. Locally in Mexico and California, a few actaeonellids are present.

In three aspects, the Campanian through Maastrichtian interval stands in marked contrast to the upper Turonian to Santonian interval. The first aspect is a lesser diversity, the second, a longer time interval, and the third, a declined proportional geographic representation. Few Campanian and Maastrichtian species 


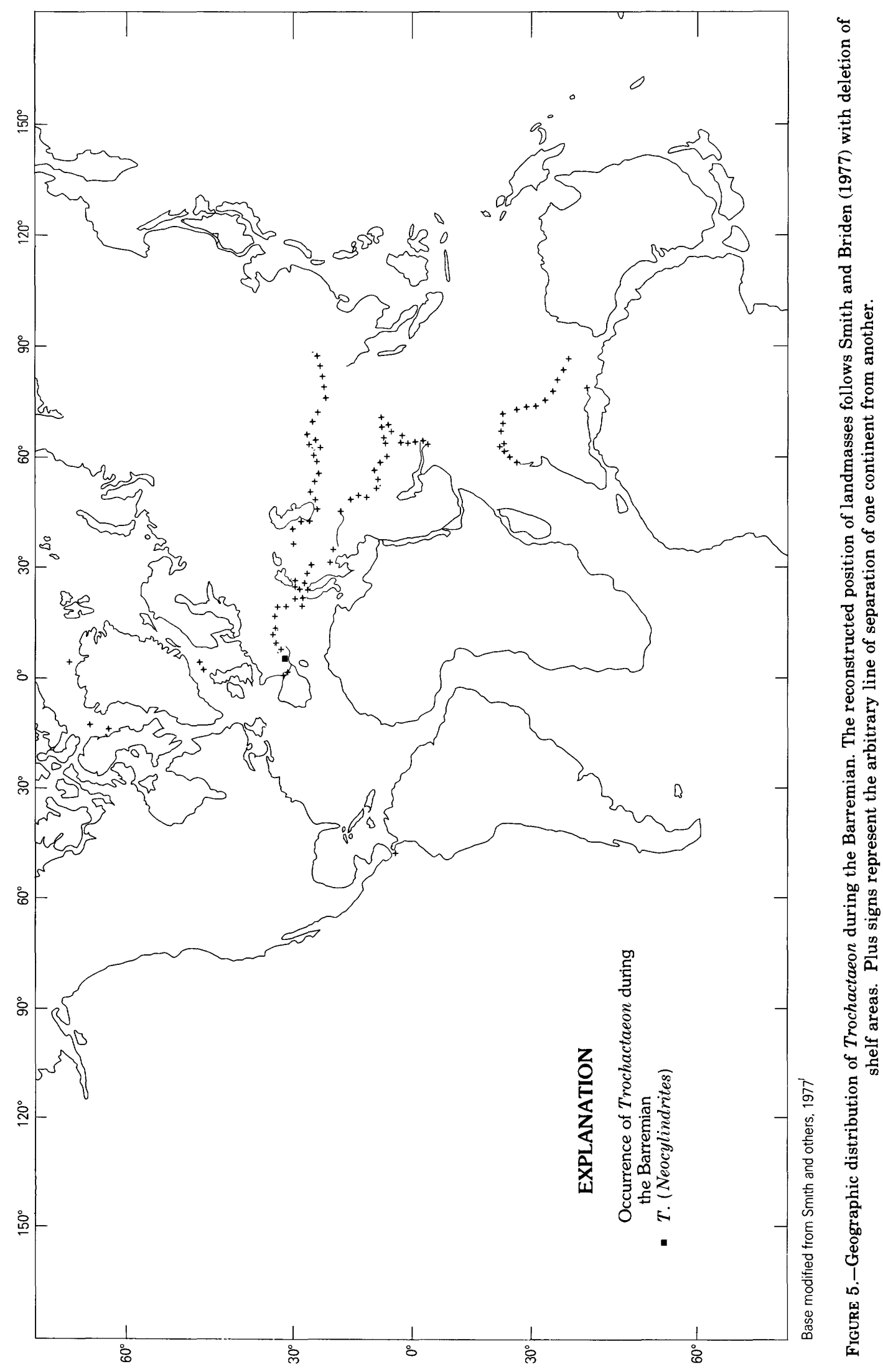




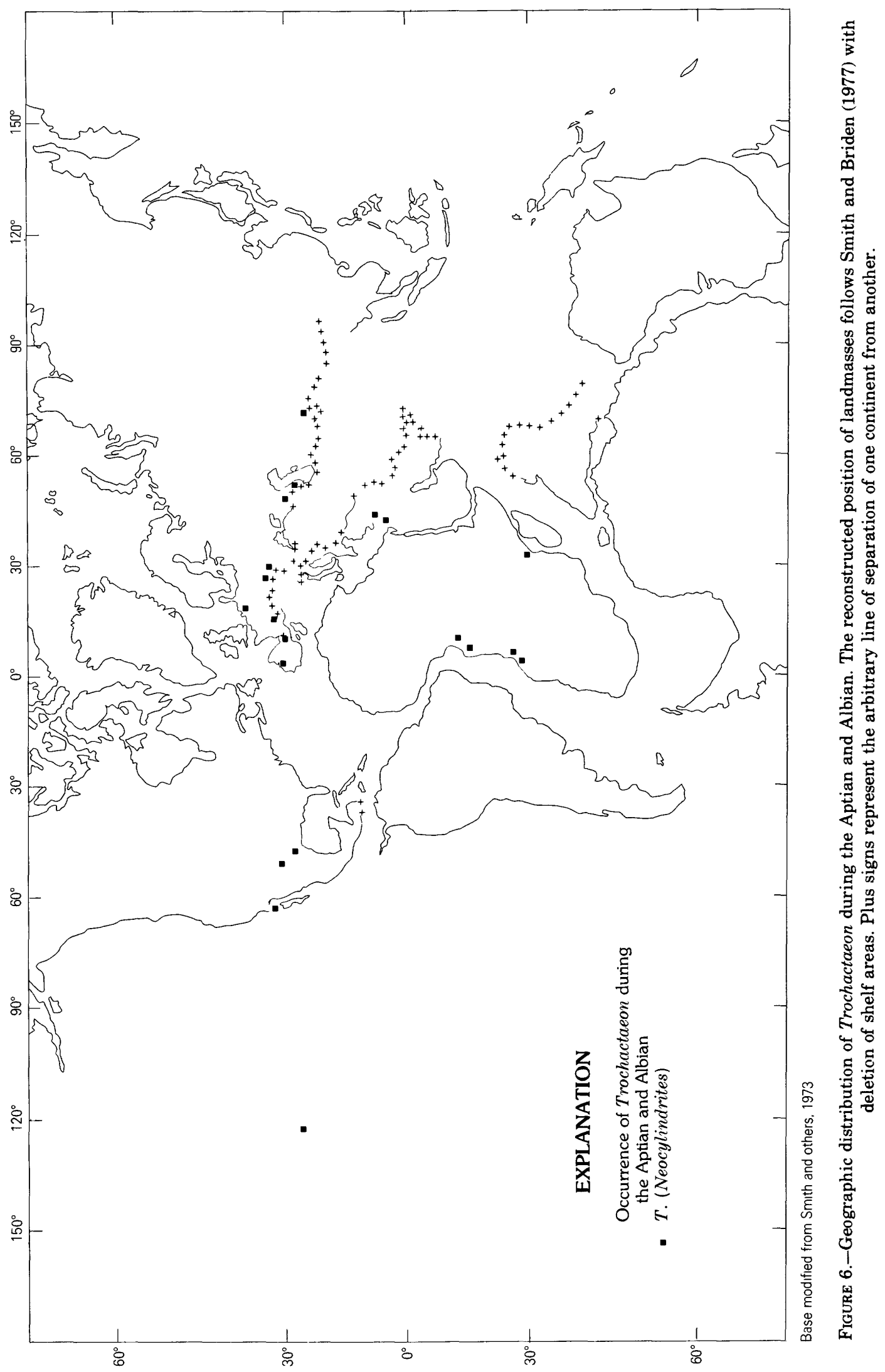




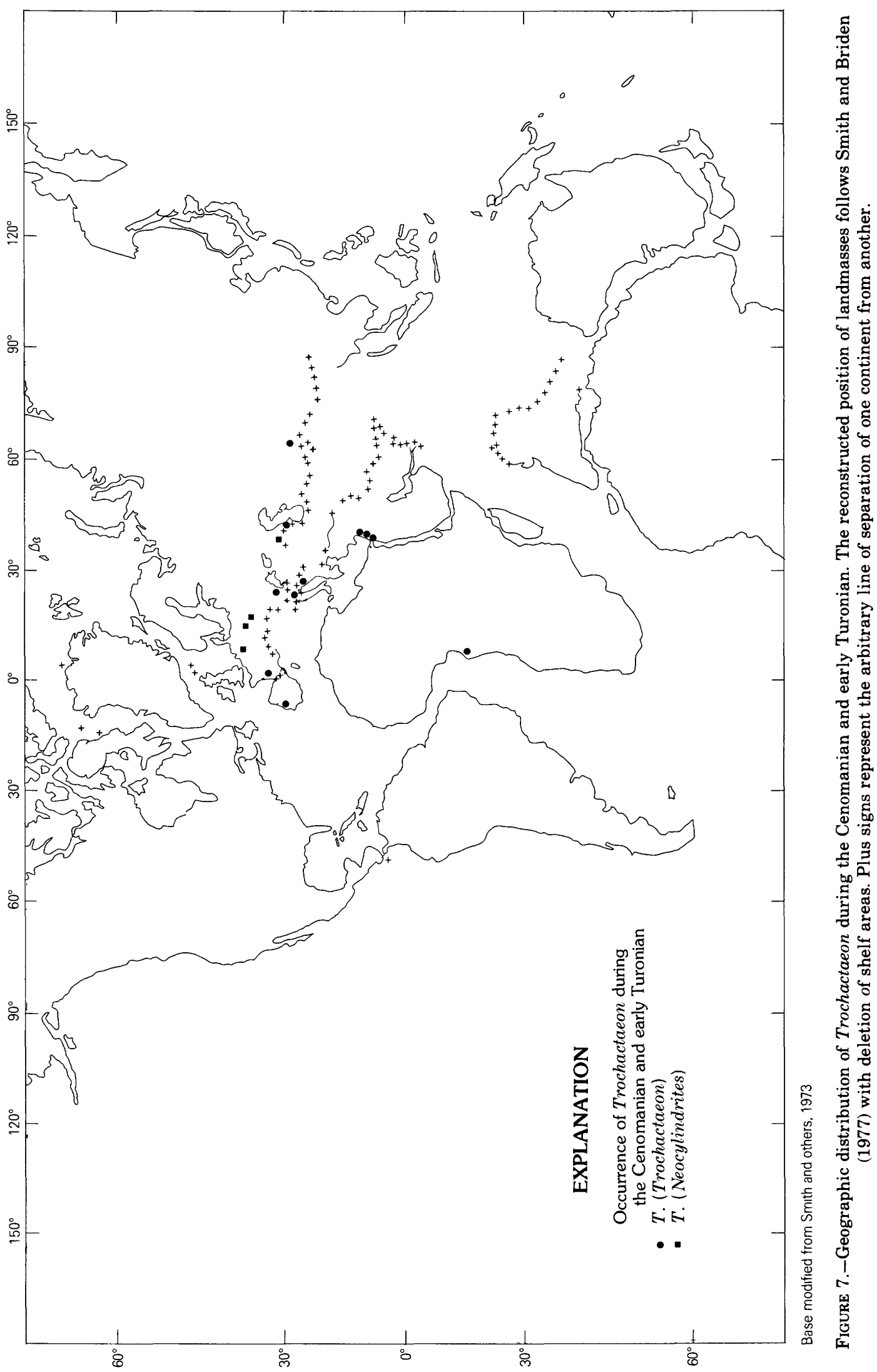




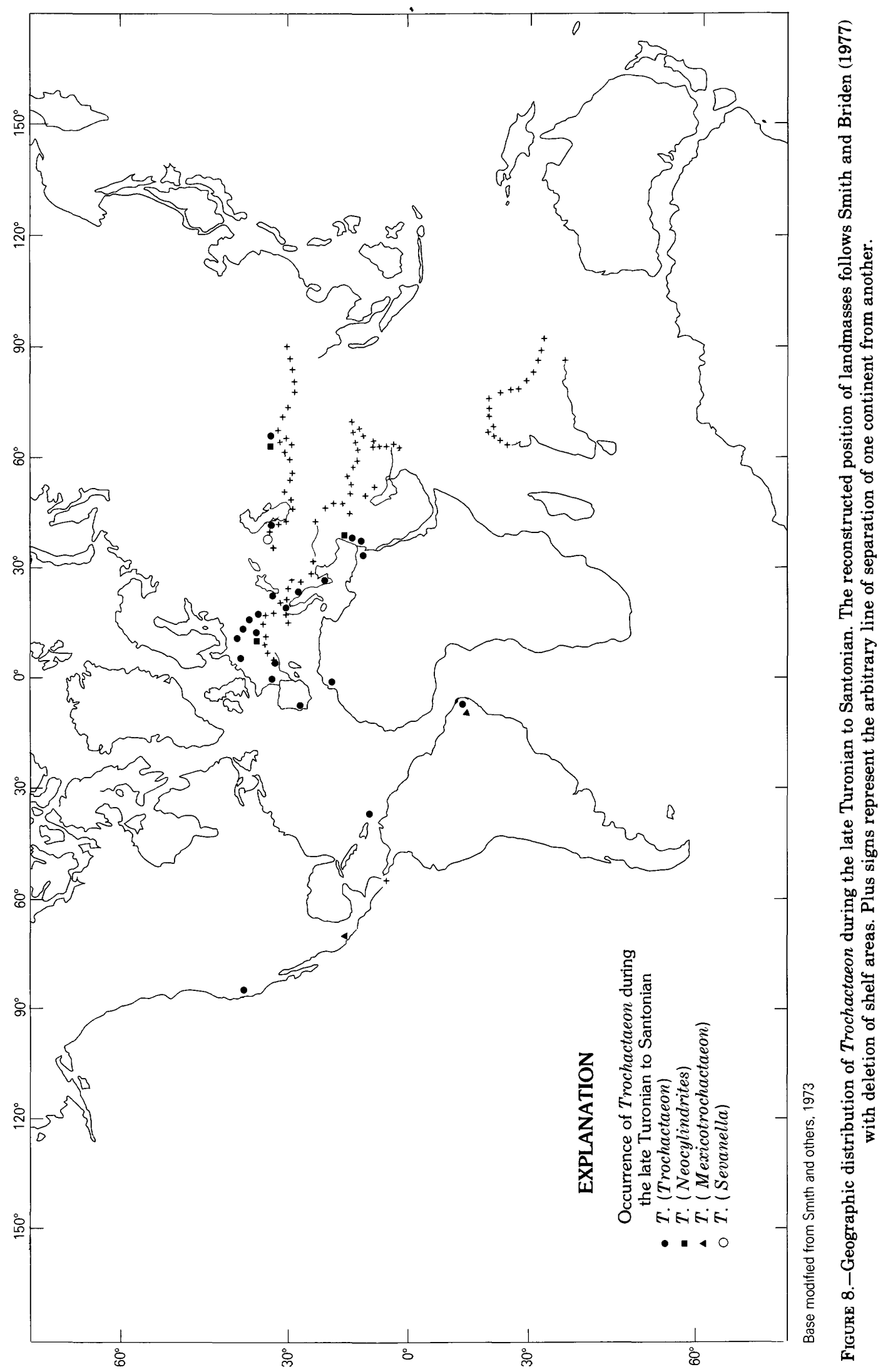




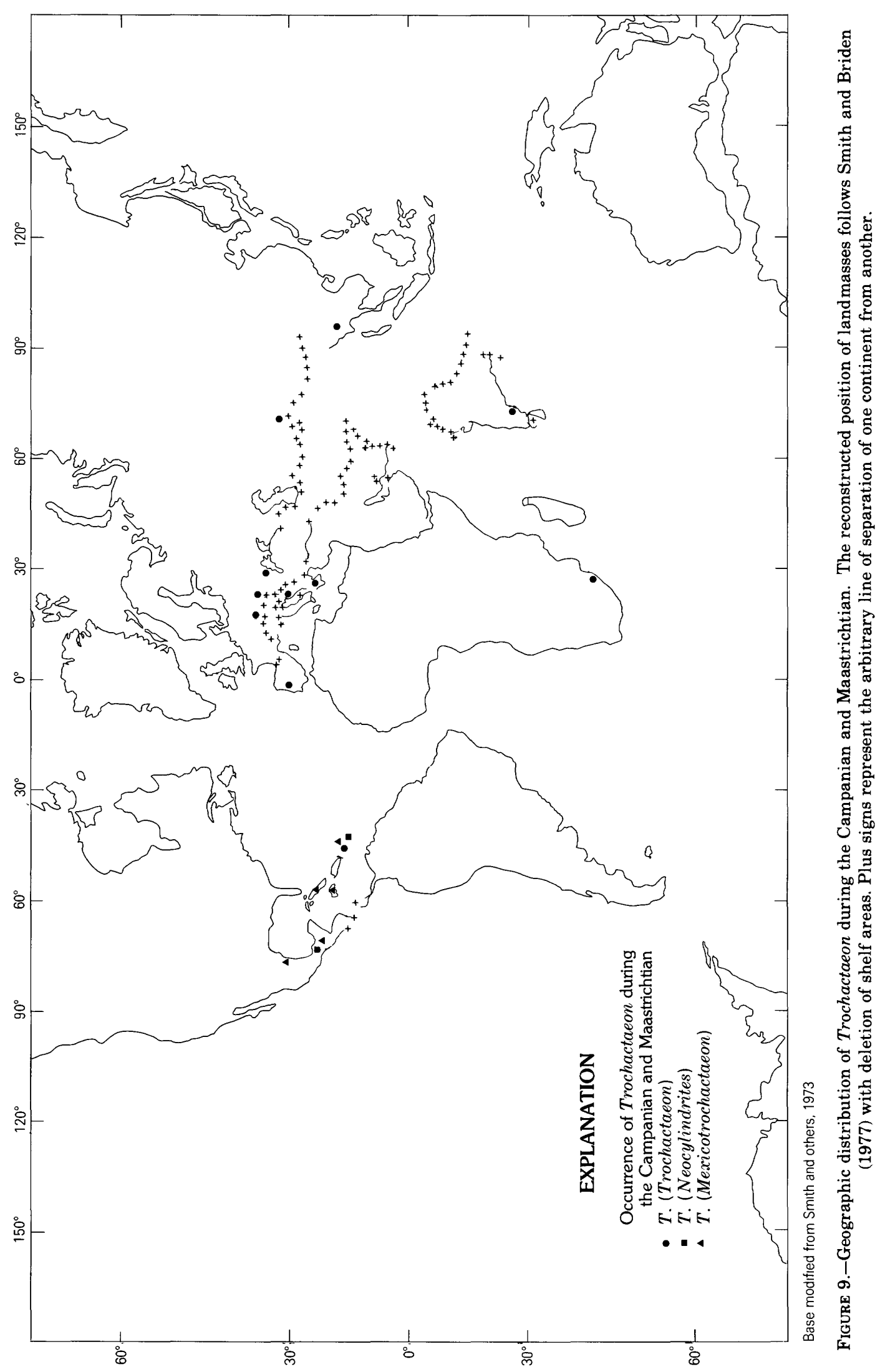



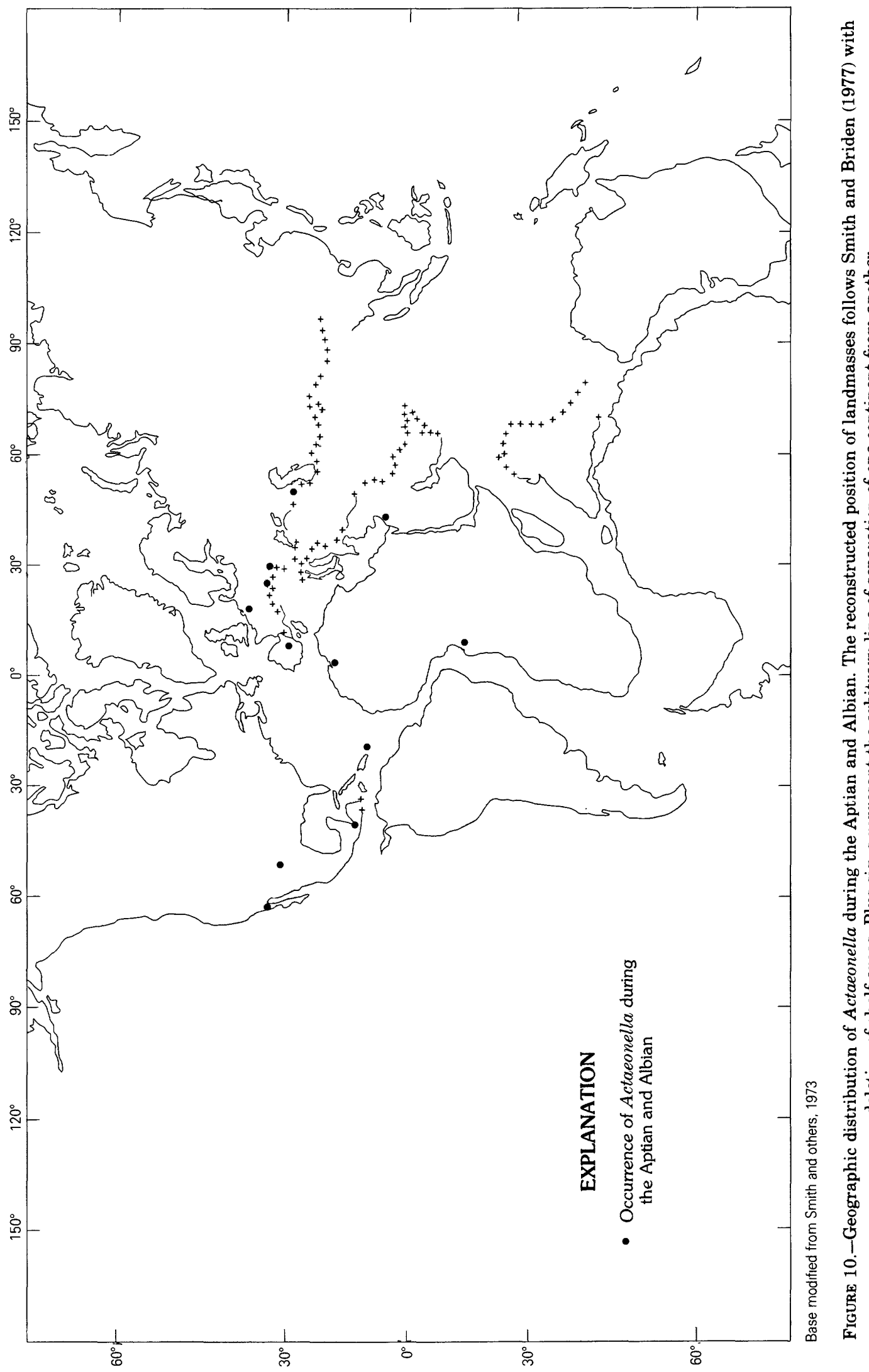


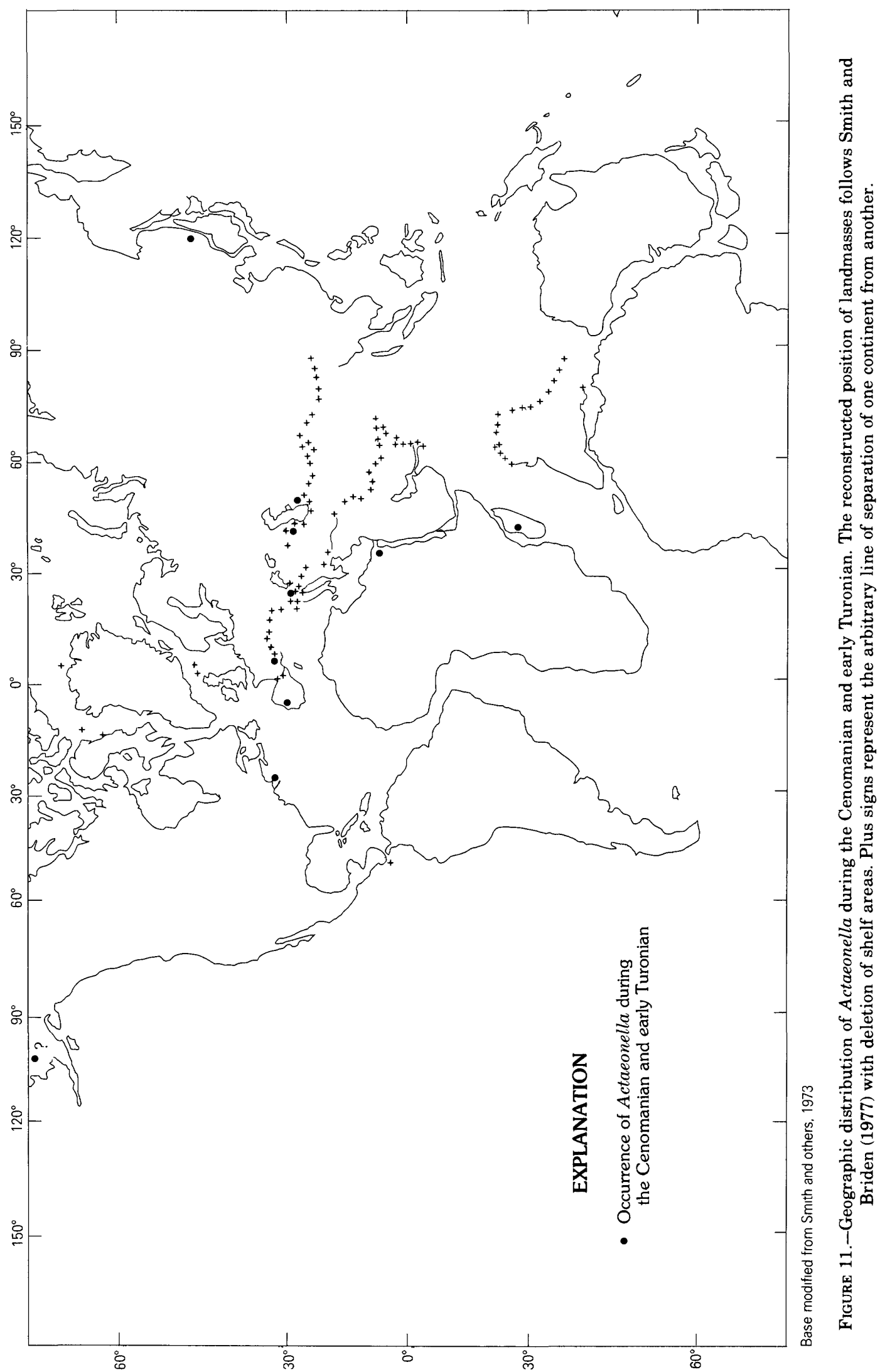




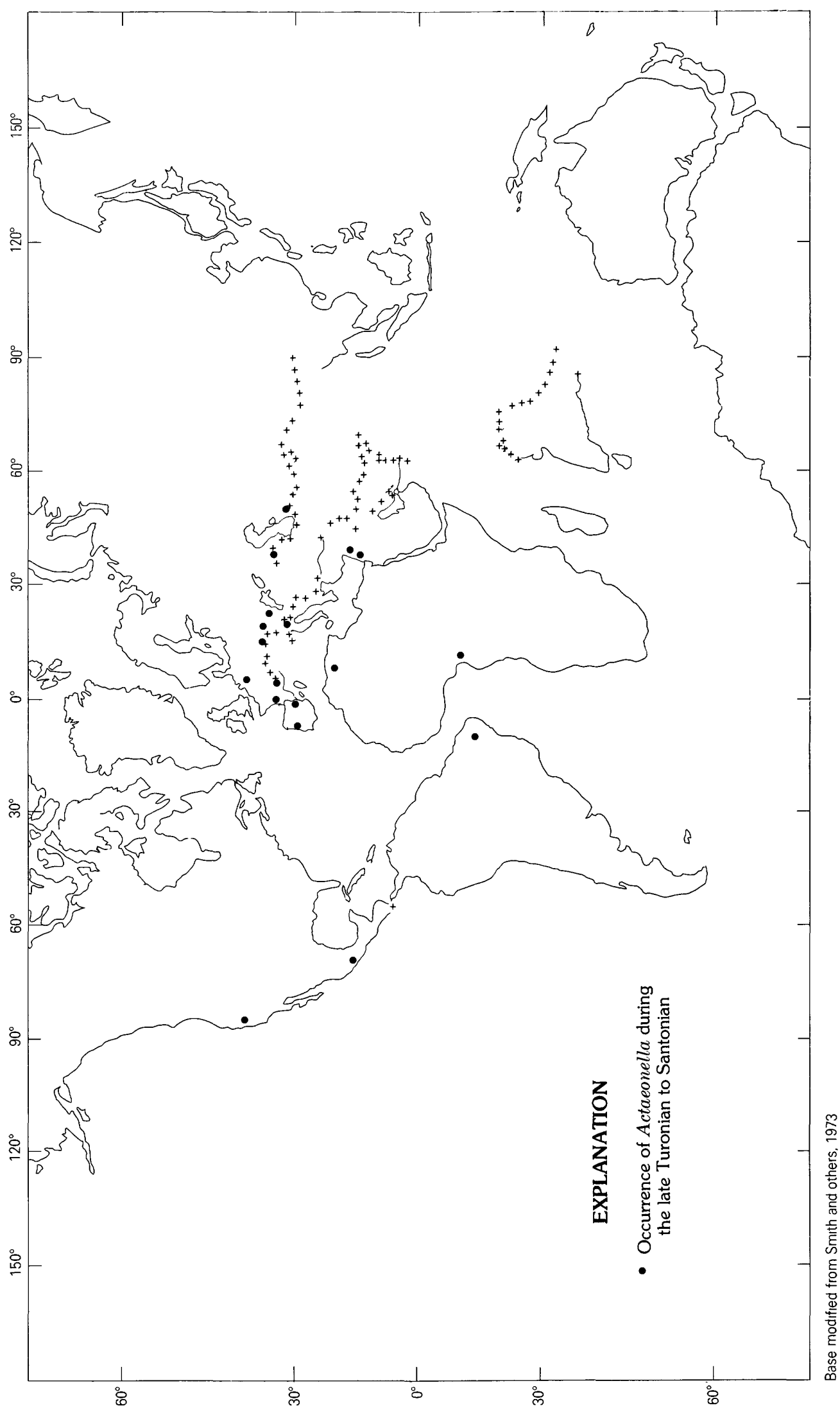

을 


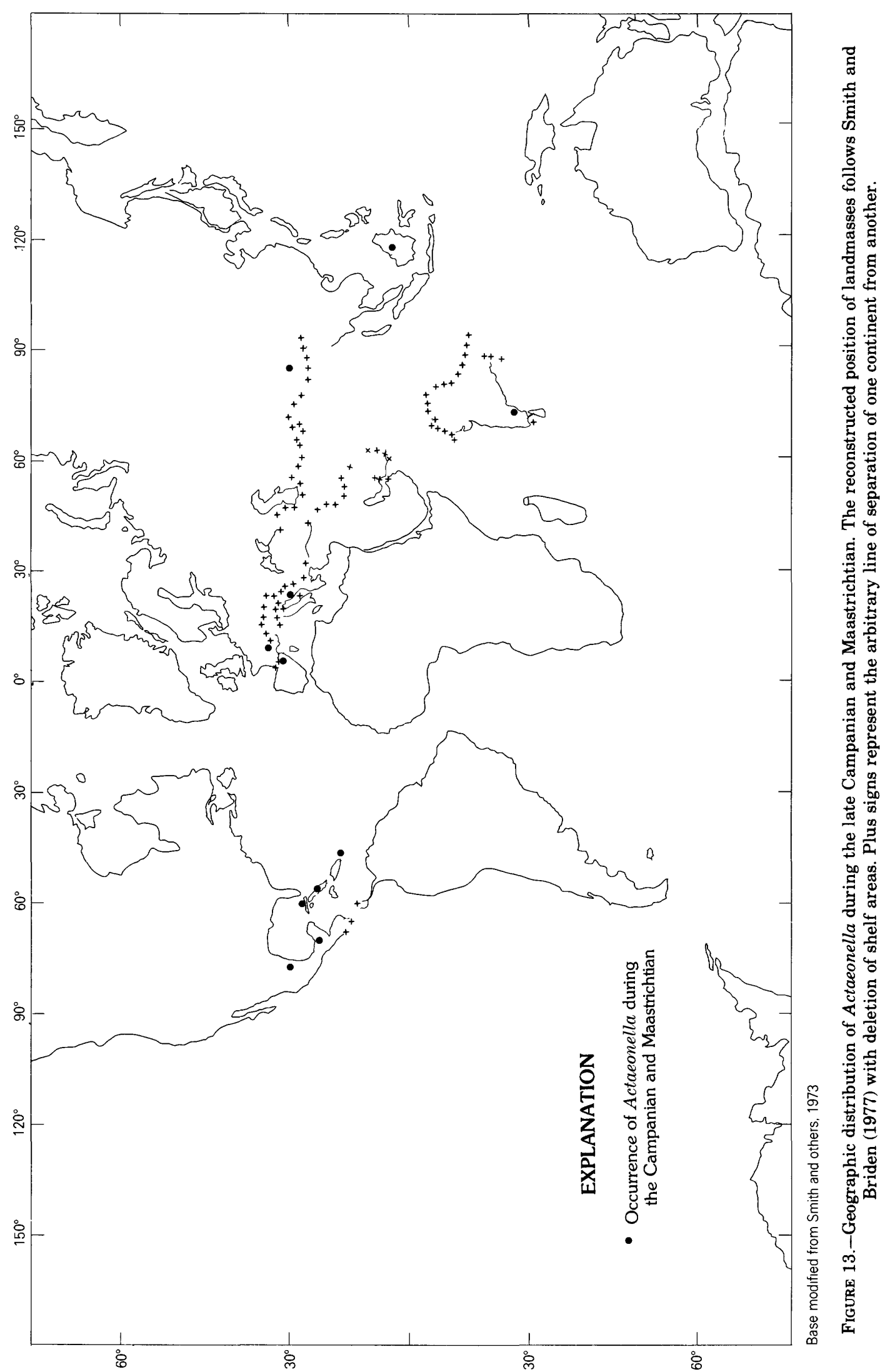


occur in the old diversity centers of Mediterranean Europe and the Transcaucasus, but the CaribbeanMexico region possesses the highest diversity of both Actaeonella and Trochactaeon. By Maastrichtian time, the Caribbean can almost be deemed a refugium.

Among the Actaeonellidae, the subgenus T. (Neocylindrites) was the first to appear. It is recorded from the Barremian of southern France by two species, Trochactaeon (Neocylindrites) barremicus Sayn and T. (N.) boutillieri Cossmann (fig. 5). T. (Neocylindrites) never attained the diversity of the other subgenera during any unit of time considered here (fig. 4), but representatives maintained a presence throughout the remainder of the Cretaceous. T. (Neocylindrites) attained its greatest distribution during Albian time (fig. 6), its range extending from Central Asia through Mediterranean Europe to Angola and westward to Texas and Baja California. By Cenomanian to early Turonian time (fig. 7), T. (Neocylindrites) was restricted to the area from the Transcaucasus to central Europe. The Campanian Maastrichtian species are restricted to the Western Hemisphere and are represented by $T$. (N.) nelsoni Sohl and Kollmann in Puerto Rico and $T$. (N.) punctatus (Maldonado-Koerdell) in the State of Chiapas, Mexico.

The nominate subgenus $T$. (Trochactaeon) shows a rapid and continuous increase in species from its first appearance in the Cenomanian through Turonian time. This increase is followed by a decrease to the Campanian to Maastrichtian interval. This viable group, however, maintains the highest diversity of any of the subgenera throughout its stratigraphic range (fig. 4). Although widely distributed in Europe, Africa, and the Middle East during Cenomanian time, no Western Hemisphere representatives are known until the Turonian when $T$. (T.) frazierensis and $T$. (T.) packardi were present in California (fig. 8). Maximum geographic range of Trochactaeon was probably attained in Campanian time (fig. 9), species being reported from such disparate areas as Pondoland, South Africa; the Trichinopoly area of southern India; and the Assam Province of northeastern India. Maastrichtian occurrences appear restricted to the Caribbean region in the form of (T.) (T.) woodsi (Rennie).

The first record of $T$. (Mexicotrochactaeon) is in the Coniacian of Mexico (fig. 8). The subgenus subsequently spread throughout the Caribbean region and is to be found in the highest Maastrichtian beds of the Antillean islands. It thus appears to be the last survivor of the genus.

T. (Sevanella) is a short-lived Coniacian to Santonian endemic subgenus restricted to Transcaucasian U.S.S.R. (figs. 4, 8).

Actaeonella first occurs in beds of Aptian Age; it is represented by $A$. fusiformis Coquand from Spain and Lebanon and A. baconica (Benkö-Czabalay) from Hungary. By the end of the Albian, species of Actaeonella are to be found eastward from this center to the Transcaucasus, southward to West Africa, and westward through the Caribbean and Texas to Baja California. Actaeonella never attained as high a species diversity as did Trochactaeon (compare figs. 3 and 4), but it is found in areas not reached by the latter (figs. 10-13). Most of these extensions are latitudinal, into marginal Tethyan areas. For example, in the Cenomanian and early Turonian (fig. 11), Actaeonella is found well north of Tethys in eastern Siberia, and in North America, it occurs well outside the normal Caribbean track on Martha's Vineyard, Mass. Perhaps the most unusual occurrence is that of Actaeonella sp. C, which is found in the Yukon River valley of Alaska. This far-north occurrence is so anomalous that it may best be explained within the framework of "suspect terranes" (Coney and others, 1980). That is, the host rock is part of an allocthonous or transported mass accreted to the North American Cordilleran margin after the middle Cretaceous. Maastrichtian distribution of Actaeonella, like that of Trochactaeon, was much reduced. Actaeonella was represented in Europe only by A. oliviformis in France and A. agricolai Vidal from the Garumnien of Spain. Despite its restricted world geographic range, Actaeonella remained diverse and abundant in the Maastrichtian deposits of the Caribbean region into the youngest Cretaceous rocks known in the area (fig. 13).

\section{EVOLUTION OF THE ACTAEONELLIDAE}

Kollmann (1967) has discussed the relationships between Cylindrites and the Cretaceous Actaeonellidae. He suggested that Neocylindrites was a direct descendant of Cylindrites that differed only by possessing a larger number of columellar plaits. He considered Neocylindrites (Barremian to Maastrichtian) to be the conservative stem from which all other actaeonellids of middle and Late Cretaceous age descended (fig. 14).

This phylogenetic relationship has been modified by Hacobjan (1972, 1976) and Djalilov (1972) (see fig. 14 for comparison). Djalilov (1972), dealing only with Actaeonella and other involute forms, derived them directly from Ptychocylindrites (Jurassic to Early Cretaceous), a nearly involute form with a depressed apical part. Among these involute genera, Omphactaeonella and Eotrochactaeon have been removed from the Actaeonellidae by Kollmann and Sohl (1979) and assigned to the Itieriidae. Hacobjan $(1972,1976)$, on the other hand, is in favor of separate phylogenetic 


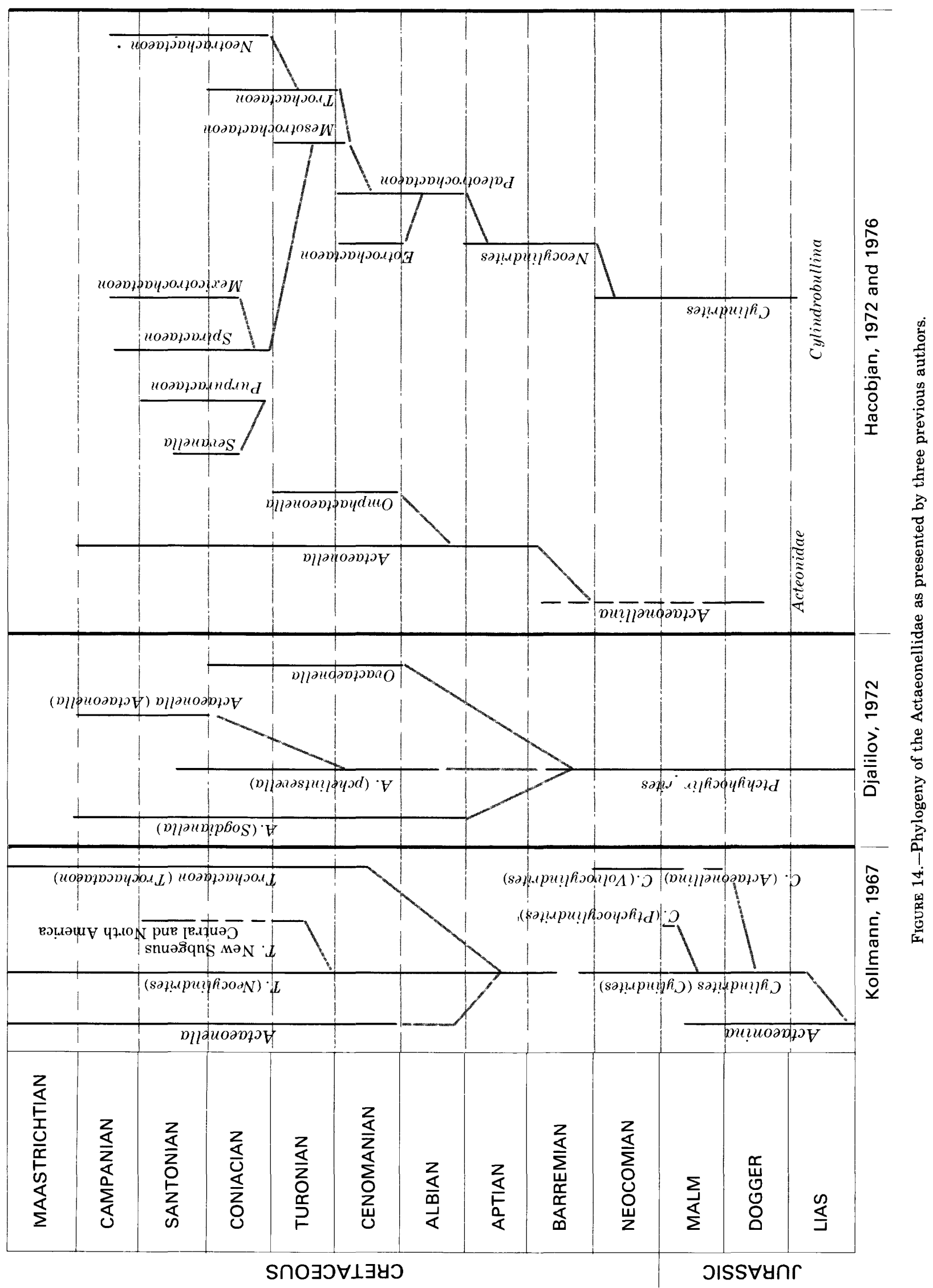


origins for the spired and involute forms of Actaeonellidae. He derived Actaeonella from Actaeonellina Pchelintsev, 1963, and T. (Neocylindrites) from Cylindrites. Although morphologic agreement is good among the genera Ptychocylindrites, Actaeonellina, and Actaeonella, we do not agree with the direct descendance of Actaeonella from one of the two other genera, as was proposed by Djalilov and Hacobjan. The paleontological record shows that $T$. (Neocylindrites) occurred much earlier in the Cretaceous than did Actaeonella. Both Cylindrites and T. (Neocylindrites) are found in Barremian rocks, but neither Actaeonellina or Ptychocylindrites occur in Lower Cretaceous rocks. For this reason, we maintain the phylogenetic position of $T$. (Neocylindrites) as the older and conservative stem in the family from which all other, mostly Late Cretaceous forms, have descended (fig. 15). Actaeonella arose from this stem in the late Aptian by an increase in overlap of the whorls, leading ultimately to an involute shell form. Evidence for this evolutionary transition stage is shown by Actaeonella fusiformis Coquand from the Aptian of Spain and Lebanon. In this species, the overlap is still not total, so that the early whorls are still visible.

The normal base plan of three columellar plaits is present throughout the geographic and stratigraphic range of Actaeonella. The species described in this paper that bear only two plications occur in the Maastrichtian of Cuba, Jamaica, and Mexico (fig. 15) and are considered only a congeneric Caribbean endemic offshoot of the primary Actaeonella lineage.

Trochactaeon (Trochactaeon) is proposed to have evolved from $T$. (Neocylindrites) during the upper part of the Cenomanian. The transition involved an increase in proportional breadth of the shell and an increase in spire height. In general, Cenomanian species such as T. (Trochactaeon) matensis (Fittipaldi) and T. (Trochactaeon) pseudocylindraceus (Pschelintsev) remain morphologically close to $T$. (Neocylindrites), as the whorls are only slightly inflated. In the Western Hemisphere, this form group, which was named Mesotrochactaeon by Hacobjan $(1972,1976)$, is represented by the California Turonian species T. (Trochactaeon) packardi (Anderson) and T. (Trochactaeon) frazierensis (Anderson) (pl. 8).

Trochactaeon (Mexicotrochactaeon) makes its first appearance in the Coniacian rocks of Mexico (fig. 15). It differs from $T$. (Trochactaeon) in possession of a parietal fold or swelling. T. (Mexicotrochactaeon) is restricted in distribution to the Western Hemisphere, but in this area it diversified rapidly, and, with the exception of the noded T. (Trochactaeon) woodsi, it replaced Trochactaeon s.s. completely. The fact that Actaeonella and $T$. (Neocylindrites) both maintained worldwide dis- tribution through the Late Cretaceous may suggest that typical Trochactaeon had a lower dispersal potential. This factor, compounded by the progressive separation of the Caribbean area from Europe during postCenomanian time, may have created an interrupted gene flow leading to endemism. To some degree, as discussed previously, this view is supported by the smaller protoconch size in Trochactaeon as compared with that in Actaeonella. In addition the only Trochactaeon to occur in post-Turonian rocks are forms related to $T$. (T.) woodsi, distinctive by being noded Trochactaeon as well as being related to forms from South Africa rather than to those from Europe.

Trochactaeon (Sevanella) Hacobjan (1972) evolved from Trochactaeon (Trochactaeon) and consists of a short-lived (Coniacian to Santonian) group of species endemic to the Armenian SSR. They are all heavily noded shells with laterally depressed whorls.

Actaeonellids became extinct at the end of the Cretaceous. This extinction parallels that involving many other groups such as nerineid gastropods and rudist bivalves that were dominant components of the Tethyan shallow-water Cretaceous marine assemblages. Whatever cause one proposes for these extinctions, the fact remains that the Actaeonellidae were declining in diversity during the latter part of the Late Cretaceous prior to extinction (figs. 3 and 4). Parallel to this decline in the diversity of actaeonellids was a rise in the diversity of gastropod groups of similar habit. Cephalaspidean gastropods and neogastropods are dominantly carnivores and both increased markedly in diversity during Late Cretaceous time. The early evolution of the neogastropods was restricted to the boreal and temperate seas (Kollmann, 1979). During the Albian, the neogastropods invaded the Tethyan seaways in which the actaeonellids were already established. During the Late Cretaceous, the neogastropods increased significantly, occupied increased numbers of ecologic niches, and in essence must have come into direct competition with the Actaeonellidae. Also during this time, new feeding habits in other groups such as the Naticidae (Sohl, 1969) suggest a concomitant effect on existing food chains and disruption of prevailing biological equilibrium on the existing surface and substrate of the sea bottom. That the decline of the actaeonellids coincides with these events seems more than mere coincidence.

\section{STRATIGRAPHIC SUMMARY OF WESTERN HEMISPHERE ACTAEONELLID OCCURRENCE}

Actaeonellid gastropods occur sporadically but are locally abundant in Cretaceous rocks of post-Aptian 


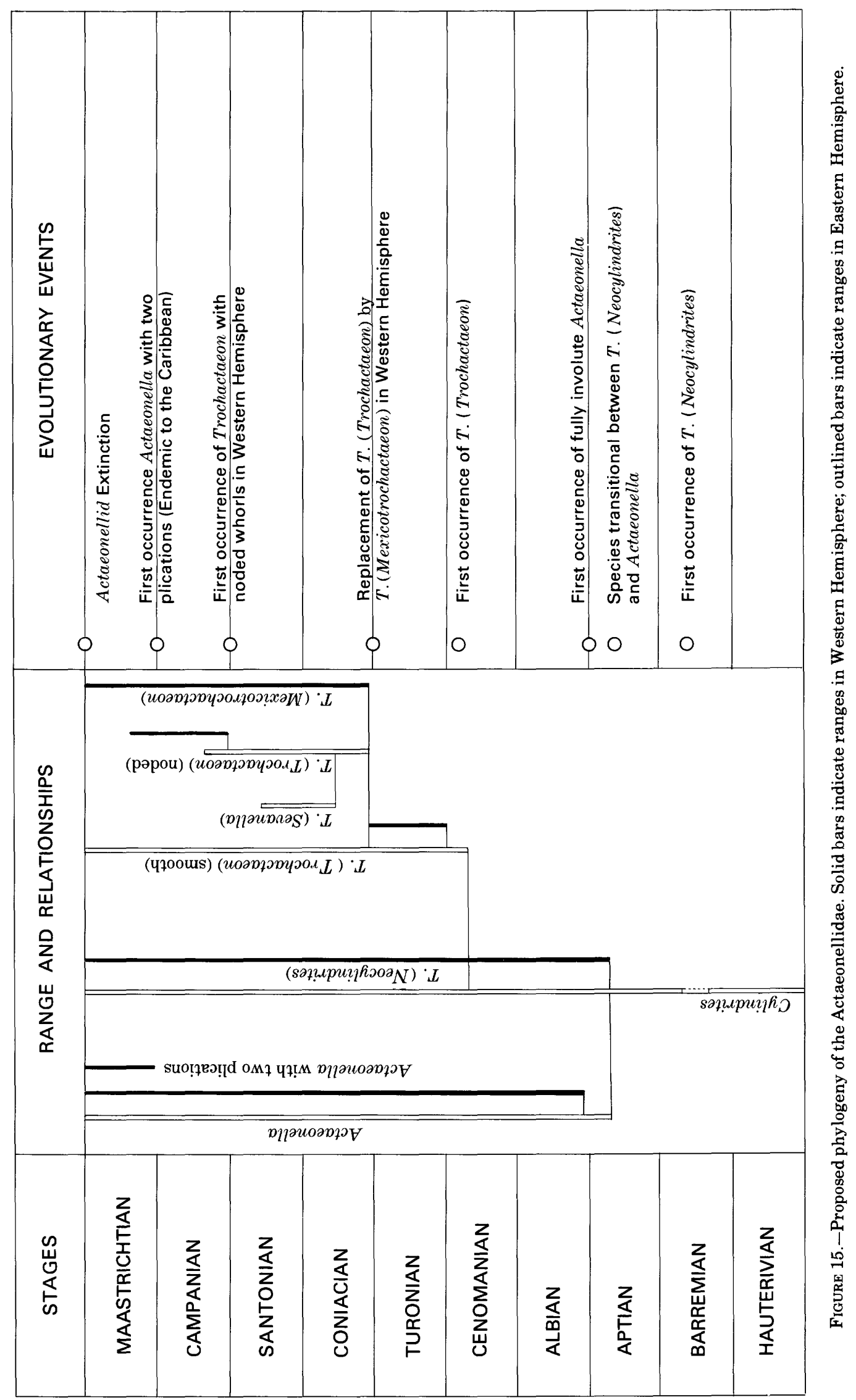


Age throughout the Western Hemisphere (figs. 16-25). Their absence in rocks of Aptian Age is unexplained, as seemingly suitable facies were present in such areas as southern Mexico (Allencaster de Cserna, 1956) and the Benbow inlier of Jamaica (Sohl, 1979), where their common associate the nerineid gastropods are abundant. Figure 19 shows that actaeonellids are most diverse during the Albian and the Campanian to Maastrichtian time in the Western Hemisphere. This might be predicted from the fact that this time coincides with widespread carbonate-shelf deposition in the Caribbean to Middle America region, thus providing optimum environmental conditions for the establishment of actaeonellids. This phenomenon finds a parallel in the episodic rudist-framework-building activity noted by Kauffman and Sohl $(1974,1979)$ for the Caribbean region.

In this region, correlation of the units within which actaeonellids occur is based primarily upon a rudist bivalve biostratigraphy. The endemic nature of the rudist faunas, however, precludes their utilization for intercontinental correlation. Age assignments are therefore based upon the conventional biostratigraphic tools of ammonite, inoceramid, or planktonic foraminifer associations. For some areas, such as Texas, the formations are firmly dated because of the intensive work that has been done and the abundance of biostratigraphic information. In other areas, such as the Antillean islands, critical dating fossils are rare in the dominantly volcaniclastic sequences. Thus, the correlations of formations presented on figures 17 and 18 rest mainly on summaries provided by Pessagno (1979) for foraminifers, Kauffman (1979) for inoceramids, and Sohl (1979) for ammonites and other macrofossils. The rudist bivalve ranges presented on these figures are based primarily on the studies by Dommelen (1971) and MacGillavry (1977) and on unpublished observations of Sohl.

Precise information on the localities at which the actaeonellids discussed here were found is provided in the locality register (p. 48). These localities have been given numbers keyed to general locality maps (figs. 20 to 25) and to the sections on occurrence in the species descriptions. Undoubtedly some new taxa and many new finds of actaeonellids will be made as work proceeds beyond the existing reconnaissance level of investigation, especially in Hispanola, Central America, and parts of Mexico.

\section{EARLY CRETACEOUS RECORD}

The record of Early Cretaceous actaeonellids in the Western Hemisphere is sporadic and restricted to rocks of Albian Age (fig. 16). In the Antillean islands, reported occurrence of actaeonellids is restricted to the eastern and central parts of the island of Puerto Rico.

Where found, as in the Barrancas Limestone Member of the Magueyes Formation in Puerto Rico (fig. 16), Actaeonella is a rare constituent in muddy lagoonal limestone associated with Caprinuloidea rudist bivalve framework sequences (Kauffman and Sohl, 1974, fig. 23, C) of early to middle Albian Age. Elsewhere, actaeonellids are locally abundant in the area from Guatemala northward to Texas and thence westward to Baja California. In all these areas they occur in rock sequences containing intervals in which faunas are dominated by rudist bivalves. Trochactaeon (Neocylindrites) cumminsi Stanton and Actaeonella peconsensis Stanton are especially common in the middle to upper Albian biosparites of the Devils River Limestone in southwestern Texas (fig. 23, localities 134, 135, 138, 139), where they are associated with abundant nerineid gastropods. Trochactaeon (Neocylindrites) cumminsi, however, is not restricted to biosparites, as it also occurs in tuffaceous siltstone of the Alisitos Formation in Baja California (Allison, 1955).

In Guatemala, Actaeonella browni is abundant and is associated with a diverse mixed assemblage of intertidal to shallow subtidal grass-flat mollusks and clusters of small rudist bivalves of probable late Albian Age.

\section{LATE GRETACEOUS RECORD}

Occurrence of actaeonellids in Upper Cretaceous rocks of the Western Hemisphere is better known. The occurrences are, overall, similar to the faunal associations of the Lower Cretaceous and parallel the track of the rudist-framework facies. Several notable exceptions to this pattern exist. The first is the occurrence of a few specimens of Actaeonella sp. (pl. 22, fig. 7) in Cenomanian rocks of Martha's Vineyard, Mass. Here (Sohl, 1977, p. 203), their association with cerithiid gastropods, Brachydontes, and other bivalves suggests a marginal marine, lagoonal to estuarine assemblage. This occurrence is latitudinally well north of rudistid distribution and probably represents an incursion of the genus north into more temperate or at least marginal Tethys waters during middle Cenomanian time.

The other anomalous Late Cretaceous occurrence is that of Trochactaeon (Trochactaeon) frazierensis and $T$. (T.) packardi (Anderson) in sandstones in northern California (fig. 25) in rocks of Turonian Age, well north of normal rudist distribution. The association here of Trochactaeon species with such genera as Trajanella suggests a northward incursion of warm-water species into a generally temperate province. 


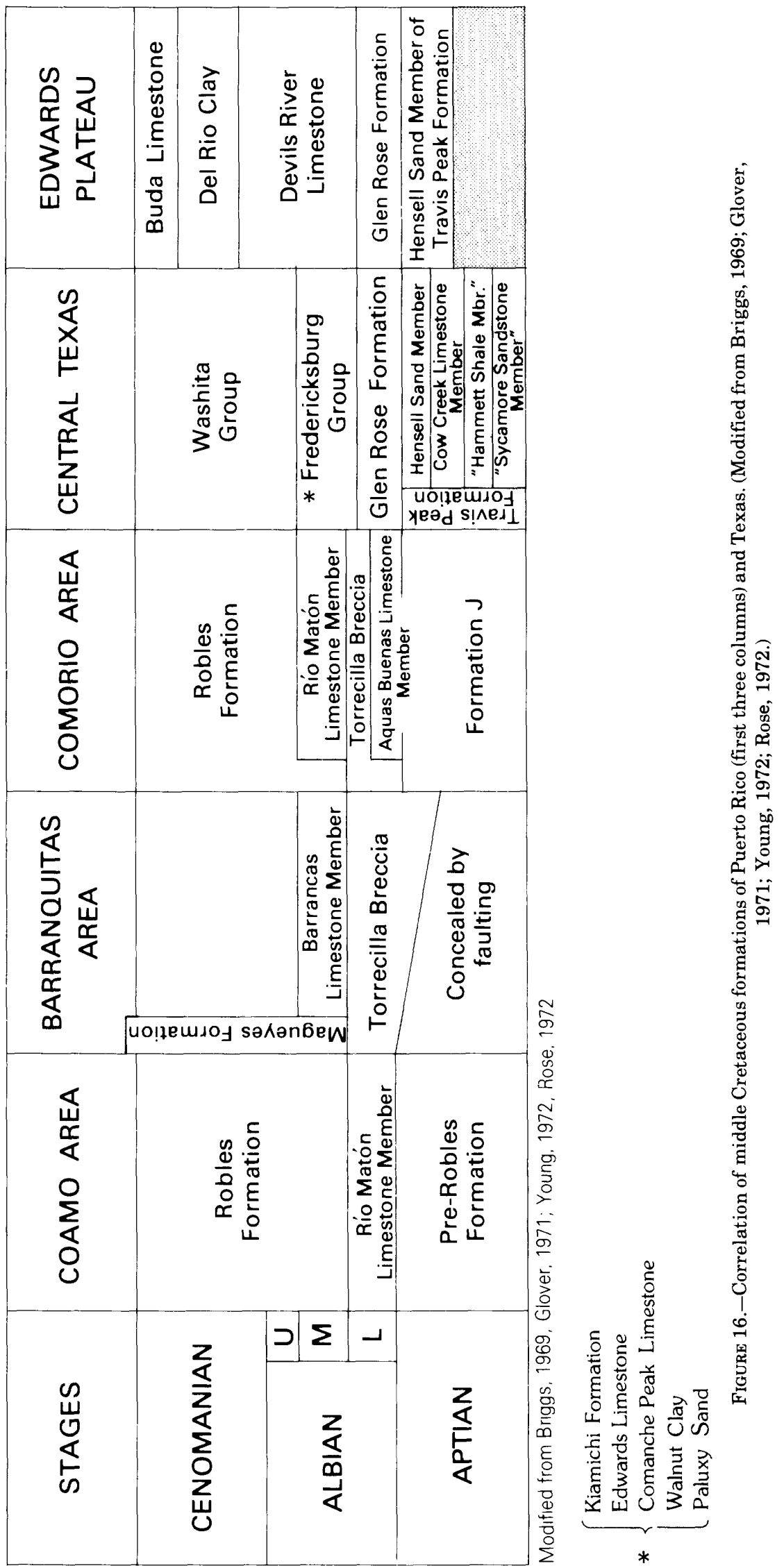




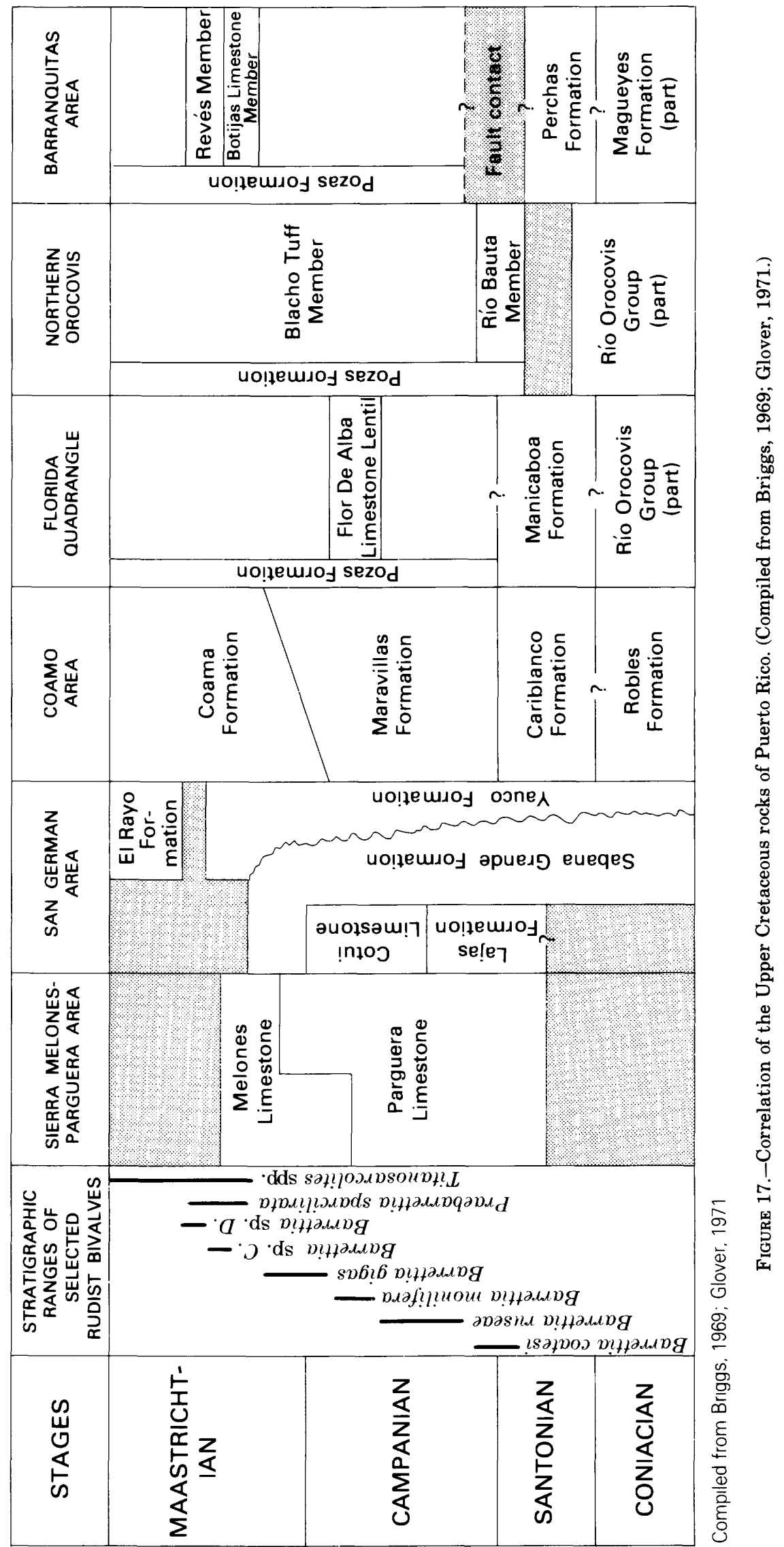




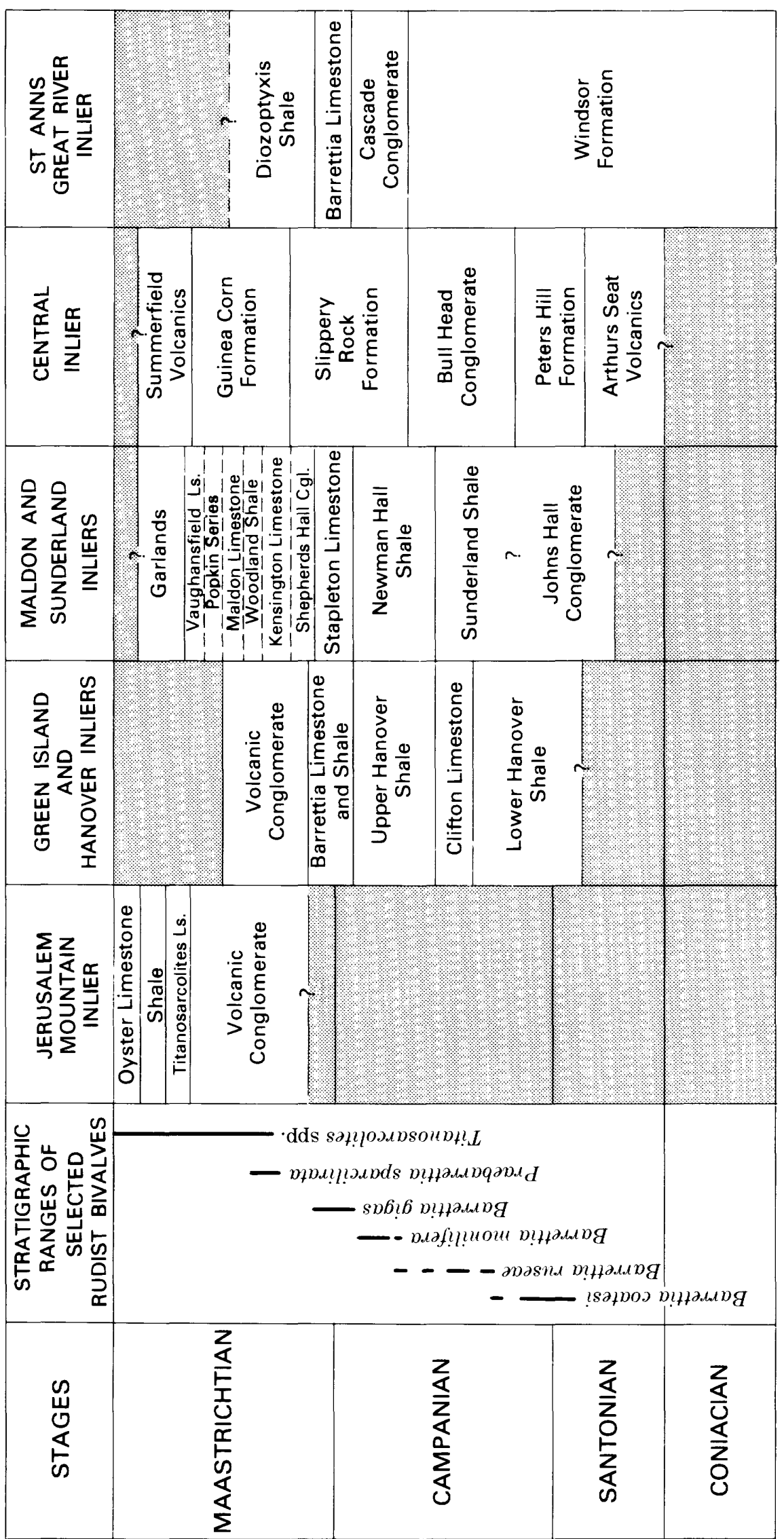




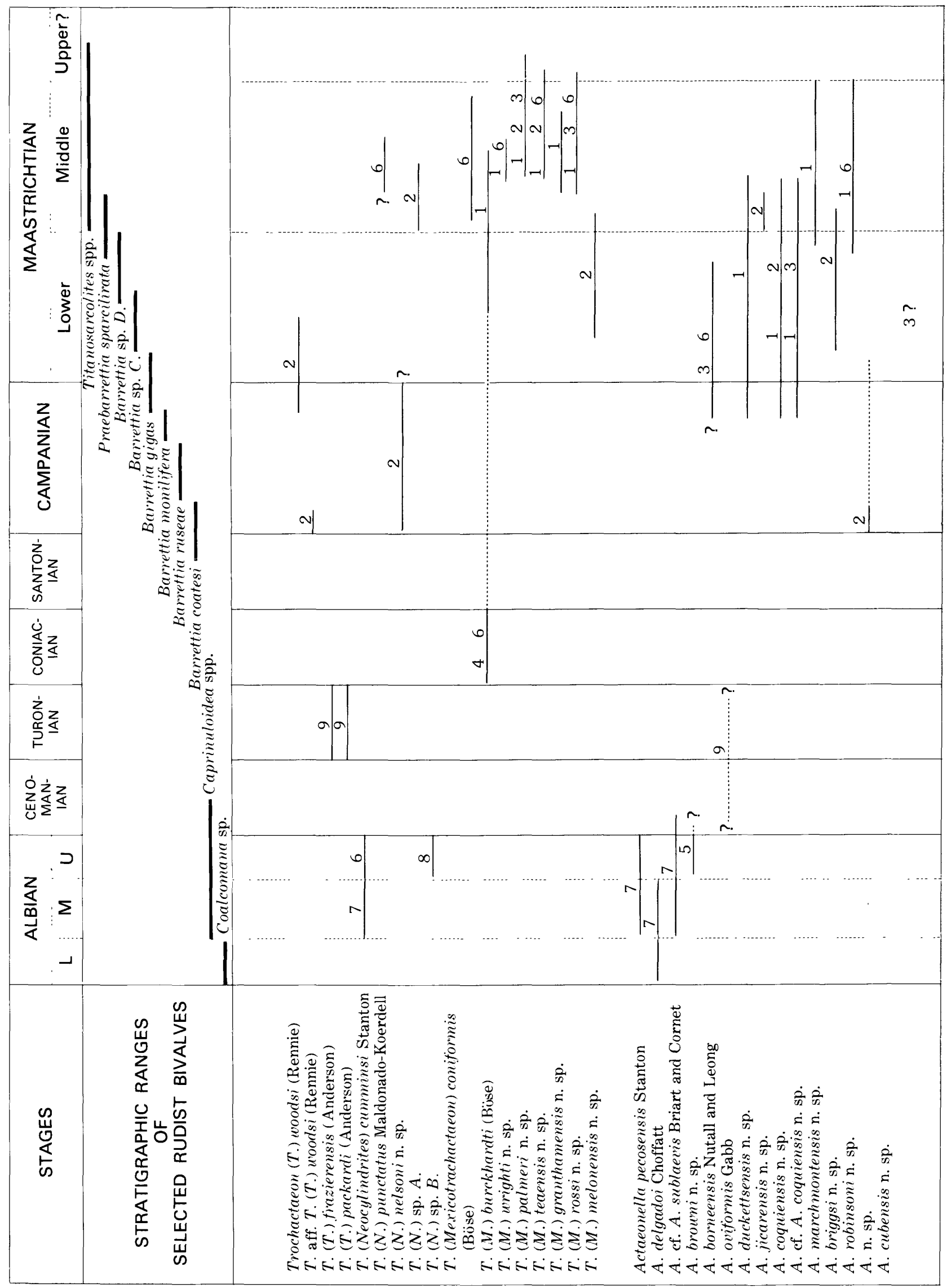




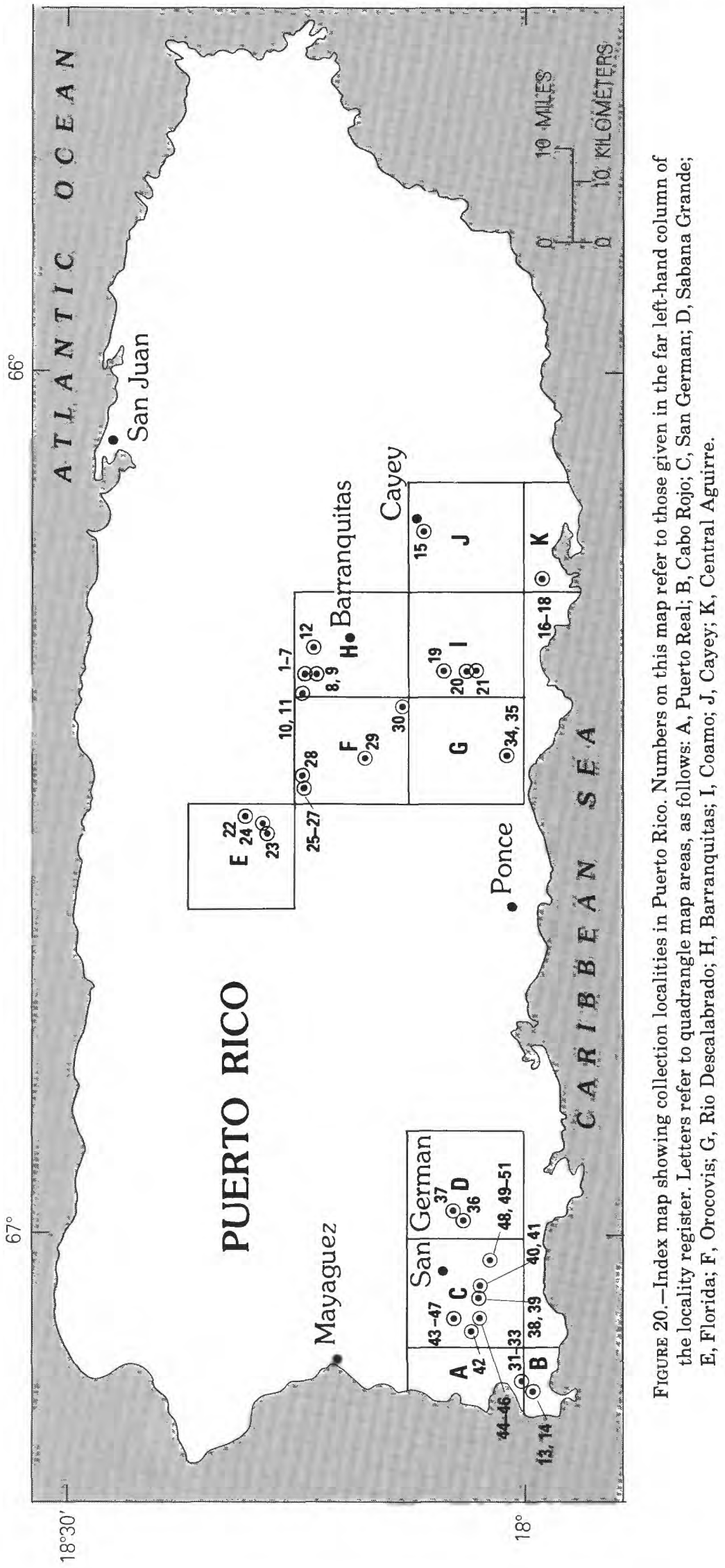




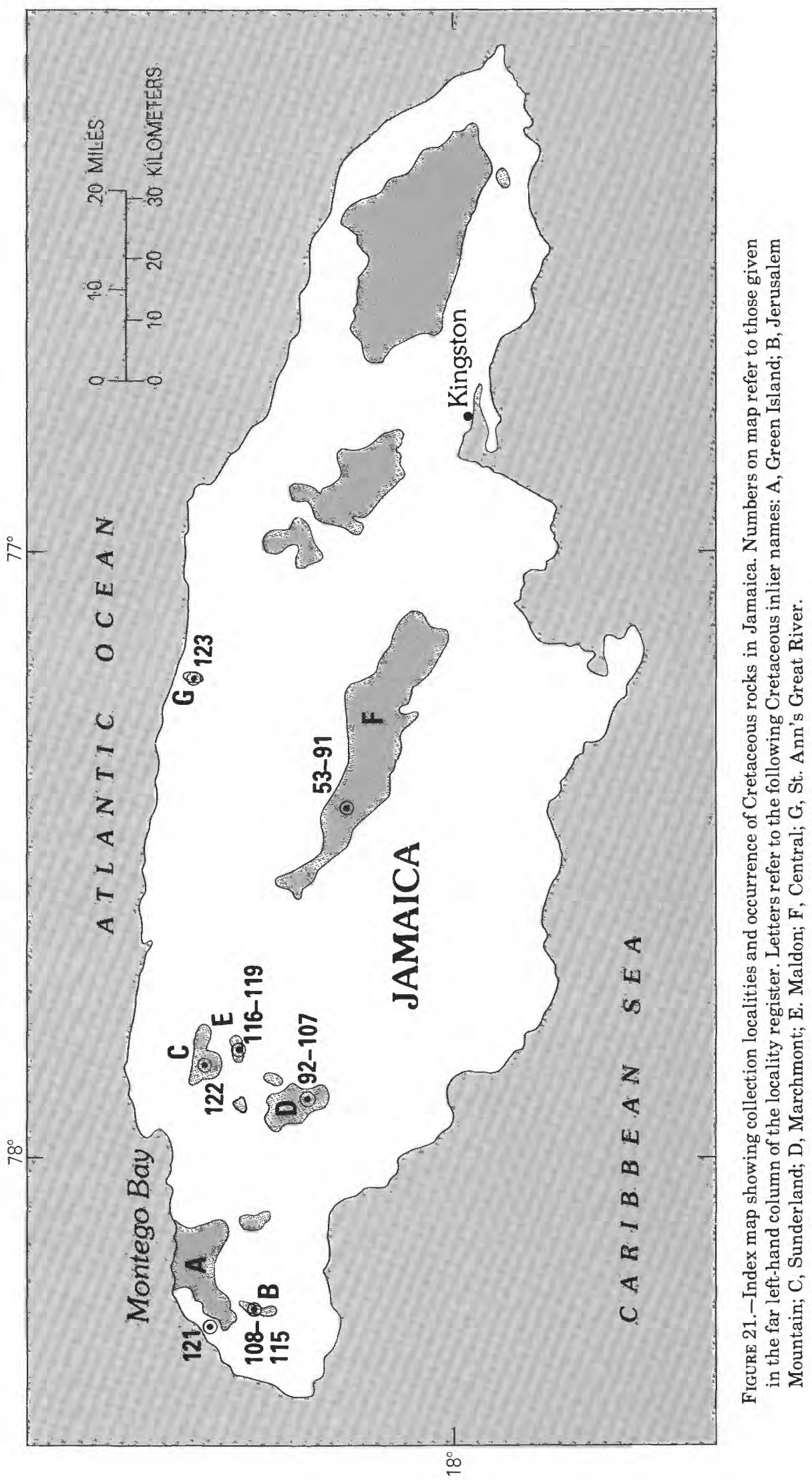




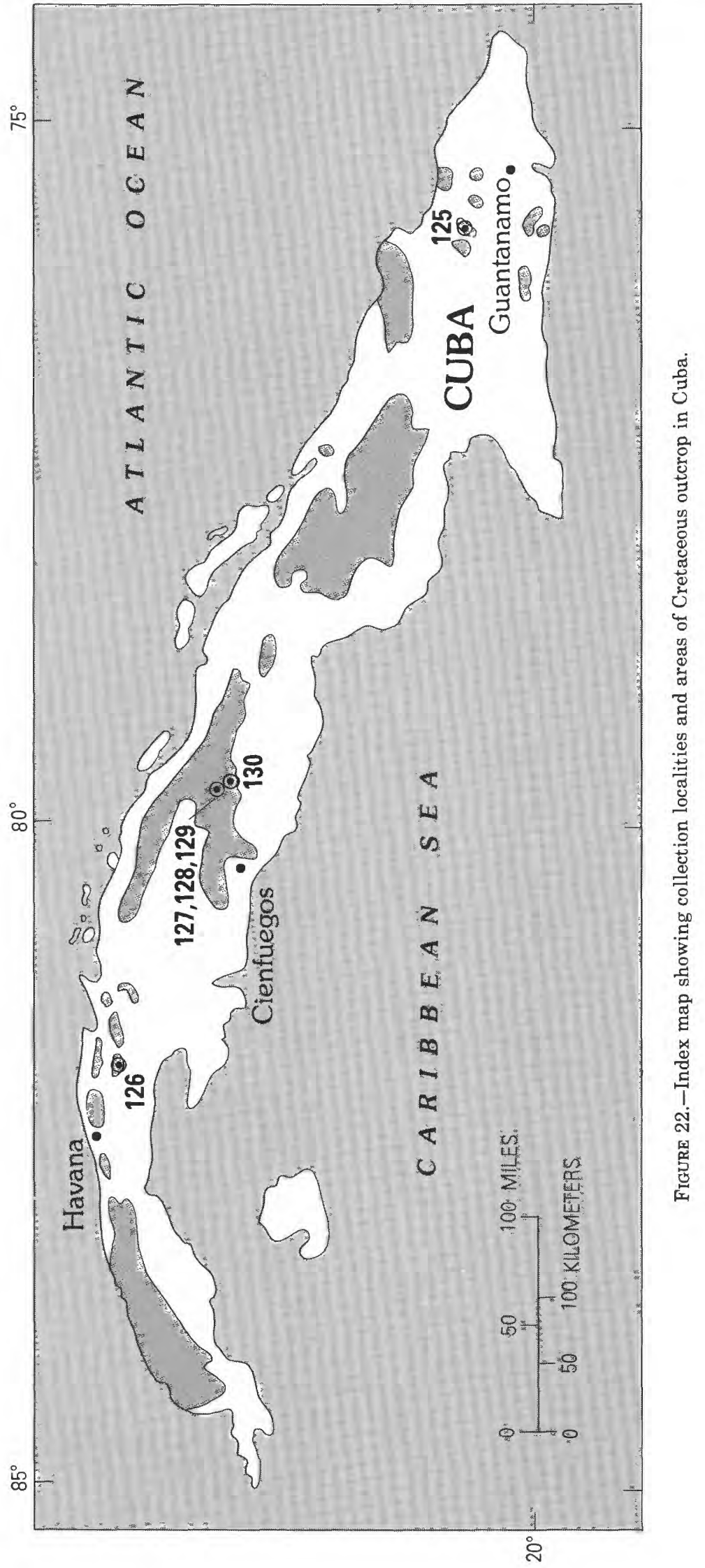




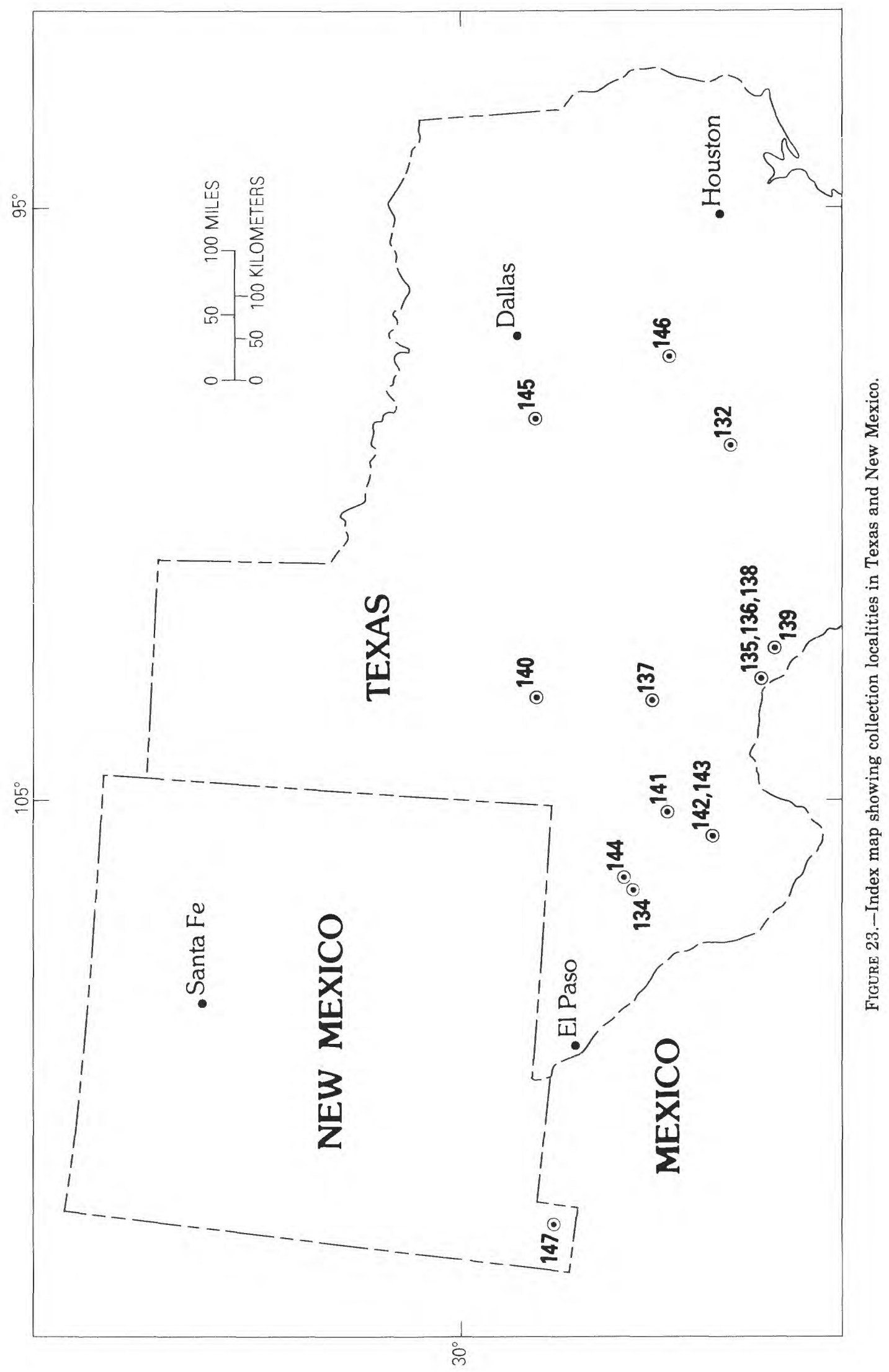




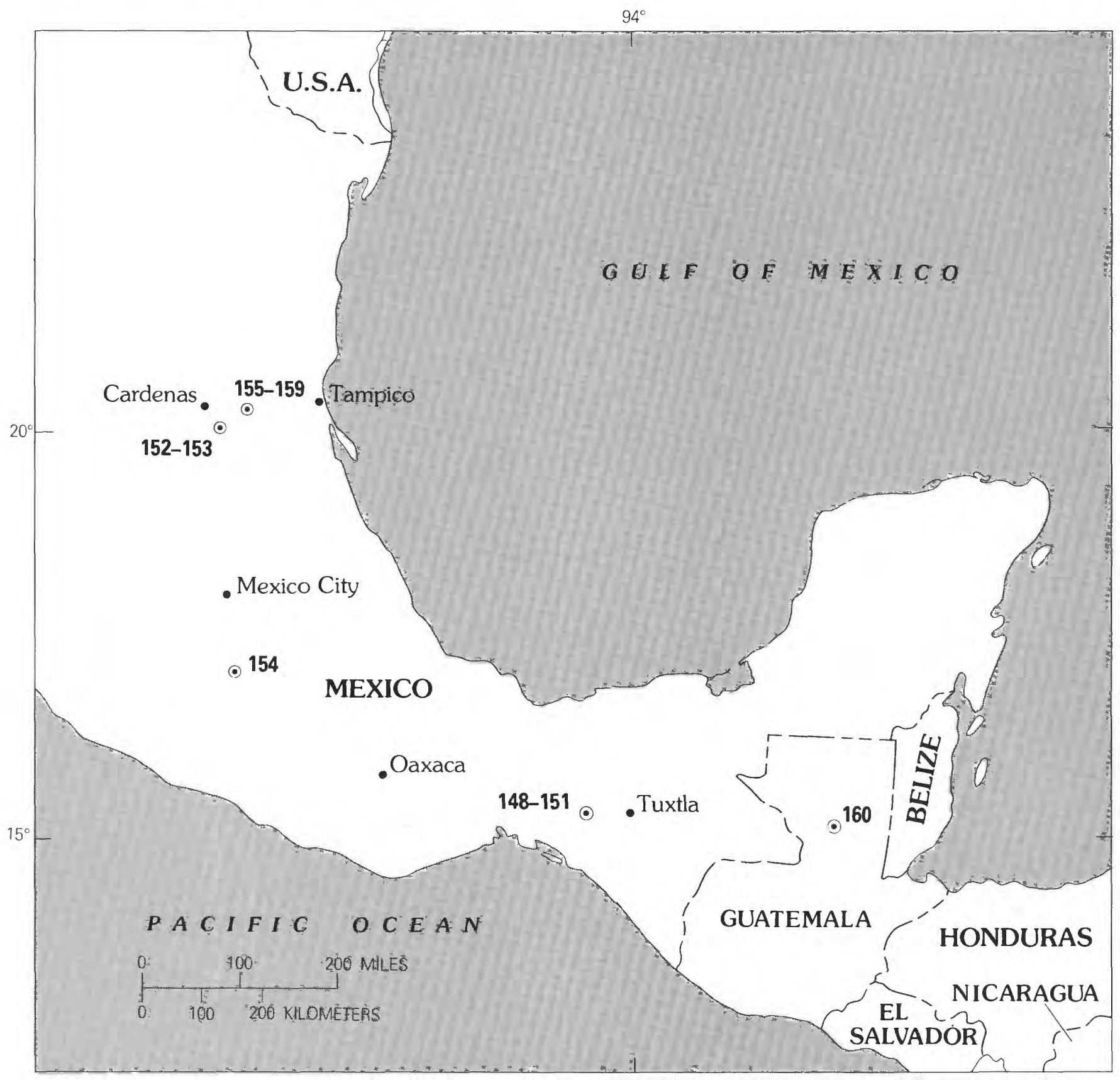

FIGURE 24.-Index map showing collection localities in Mexico and Guatemala. 


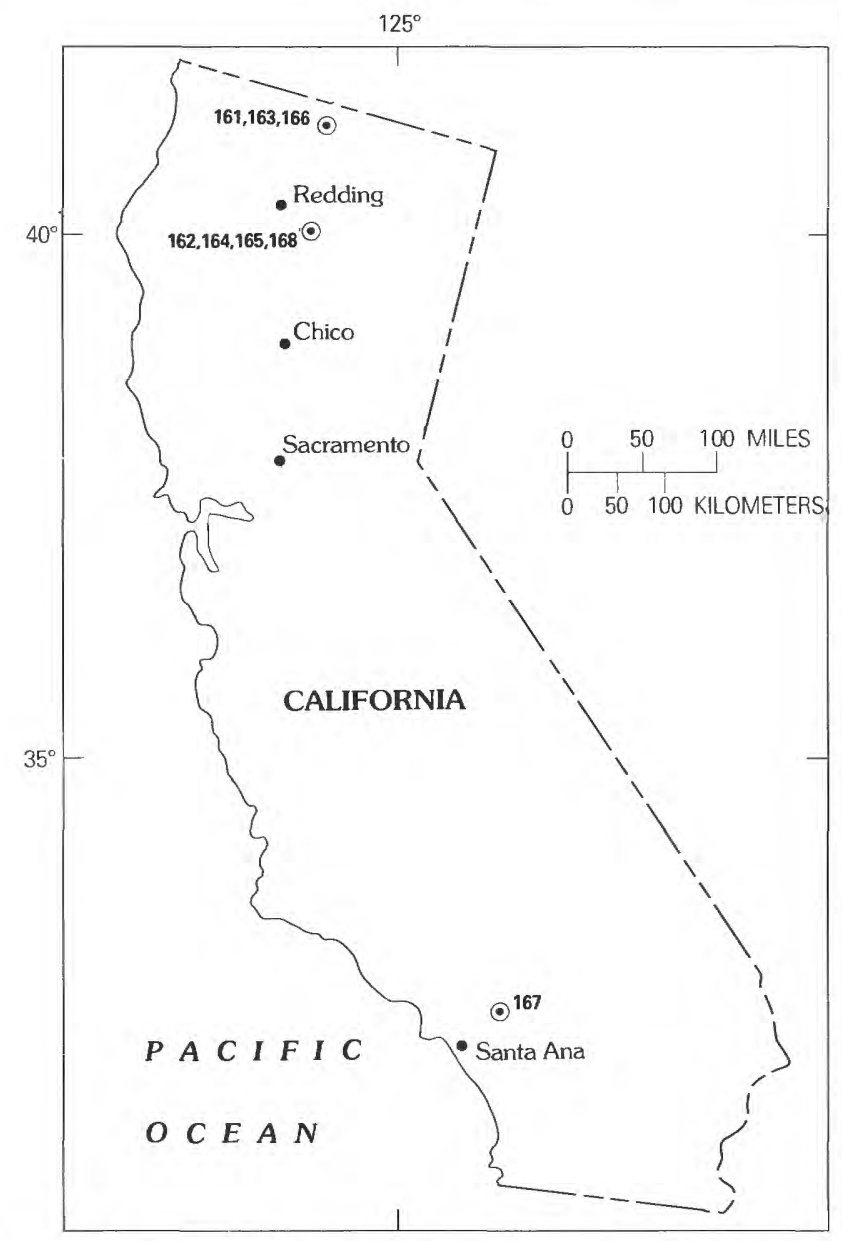

Figure 25.-Index map showing collection localities in California.

In the Western Hemisphere, post-Turonian occurrences of $T$. (Trochactaeon) are restricted to Puerto Rico, where the earliest occurrence is in the basal part of the Rio Bauta Member of the Pozas Formation of north-central Puerto Rico (fig. 20, locality 25). Here, specimens of Trochactaeon aff. T. (T.) woodsi (Rennie) occur in a calcareous tuffaceous sandstone some $3 \mathrm{~m}$ below a bed containing an abundance of Barrettia coatsi (Chubb). This hippuritid rudist bivalve in Jamaica is associated with inoceramids of latest Santonian to earliest Campanian Age (Kauffman, 1966).

The Puerto Rico occurrences of $T$. (Trochactaeon) woodsi (Rennie) represent the last appearance of the typical subgenus anywhere in the world. The species is especially common in upper Campanian rocks of the southwestern part of the island in the Cotui Limestone (fig. 17). For example, at locality 39 near Palmarejo (fig. 20), T. (T.) woodsi occurs in a zone of concentration about $0.3 \mathrm{~m}$ thick. Underlying units are dominated by Toucasia-rich limestone and nerineid-dominated shale and limestone that contain a few actaeonellids. The overlying massive biomicritic Cotui Limestone contains numerous, but scattered, large specimens of $T$. (T.) woodsi together with large nerineid gastropods. A similar successional alternation of nerineid-dominated shale overlain by $T$. (T.) woodsi-bearing limestone is found at locality 40 . The species is found in similar limestone in central Puerto Rico in the Botijas Limestone Member and Revés Member of the Pozas Formation (fig. 17) immediately below shale and limestone bearing Barrettia species $\mathrm{C}$ and D of middle Maastrichtian Age (fig. 20, localities 5-9).

Species of the Late Cretaceous Trochactaeon (Neocylindrites) are restricted to Campanian and Maastrichtian rocks in Mexico and Puerto Rico. T. (Neocylindrites) nelsoni occurs as small specimens in a tuffaceous shale in the uppermost part of the Rio Bauta Member of the Pozas Formation (fig. 17), in the Orocovis area of central Puerto Rico (fig. 20, locality 28), in beds of early Campanian Age above Barrettia coatsi, and immediately below limestones bearing Barrettia rusae?. Nearby, in the Florida Quadrangle (localities 22-24), but in rubbly limestones associated with abundant specimens of the rudist bivalves Barrettia monilifera and Durania nicholasi, larger specimens of $T$. $(N$.) nelsoni occur sporadically. This association appears to be of late Campanian Age. Trochactaeon (Neocylindrites) punctatus (Maldonado-Koerdell) although of very local occurrence in the Maastrichtian of Chiapas, Mexico (fig. 24, locality 148), marks the youngest occurrence of the subgenus in the Western Hemisphere.

Mexicotrochactaeon.-Of all subgenera of Trochactaeon present in the Cretaceous of the Western Hemisphere $T$. (Mexicotrochactaeon) has the greatest diversification of species and widest geographic distribution. The oldest record is that of $T$. (M.) burckhardti (Böse) from Coniacian rocks (Imlay, 1944, p. 1102) in the State of Guerrero, Mexico (Böse, 1923), and in Brazil (Maury, 1930).

No Santonian or Campanian records are known, but Maastrichtian species are numerous and spread throughout the Caribbean and middle America (fig. 9). Three of these species show narrow geographic spread. $T$. (M.) melonensis is restricted to the Melones Limestone of southwestern Puerto Rico in the range zones of Barrettia sp. C and sp. D of Dommelen (1971). T. (M.) coniformis is known only from the Cardenas Formation of San Luis Potosi, Mexico; it is exceptionally variable in form and abundant in the shales of this unit (Myers, 1968). Associated mollusks such as Arctostrea aquilerai and Sphenodiscus sp. suggest at least a middle Maastrichtian Age, but T. (M.) coniformis may range into beds of late Maastrichtian Age. Trochactaeon (Mexicotrochactaeon) granthamensis Sohl and Kollmann is endemic to Jamaica (fig. 21 , localities 79,106 ), occur- 
ring in calcareous shale interbedded between rudistrich limestones. In both the Guinea Corn Formation of the Central inlier and in the Marchmont inlier it occurs within the lower part of the range zone of Titanosarcolites that equates with the middle Maastrichtian.

The three remaining species of Trochactaeon (Mexicotrochactaeon) have a wider geographic range. The first, $T$. (M.) wrighti, is restricted to the Antillean Islands of Jamaica, Puerto Rico, and Cuba, but T. (M.) teaensis and $T$. (M.) rossi range from Mexico through the Antilles. All three species range through most of the middle and perhaps lower part of the upper Maastrichtian.

Actaeonella.-Cenomanian through Turonian representatives of Actaeonella are rare in the Western Hemisphere and are unknown in rocks of Coniacian and Santonian Age. In contrast, they are locally abundant and diverse in rocks of Campanian and Maastrichtian Age. In general, this pattern parallels that of Trochactaeon; however, individual species are slightly longer ranging and few are as widely distributed.

Cenomanian distribution is restricted to questionable range extensions of two species known to occur in the Albian of Texas and Guatemala (fig. 19) and to an unnamed Actaeonella (pl. 22, fig. 7) that occurs with late Cenomanian mollusks in erratic boulders on Martha's Vineyard in Massachusetts. Actaeonella oviformis Gabb demonstrates the presence of the genus in California, but its precise stratigraphic range is unknown. Although Coniacian and Santonian occurrences are unknown at present, Actaeonella may well be found in rocks of these ages in geologically unexplored parts of Middle America. Only one species currently unnamed is present in lower Campanian rocks; it occurs in shales of the Rio Bauta Member of the Pozas Formation in Puerto Rico. Late Campanian through Maastrichtian time saw a great increase in Actaeonella species diversity. Of special interest among these species is $A$. borneensis, whose distribution, which includes occurrences in the limestones of the Rancho Nuevo beds of Chiapas, Mexico, and in central Cuba in addition to its type locality in Borneo, stands in sharp contrast to the endemic Caribbean-Middle America distribution of the other coeval species. This affinity with Indo-Pacific faunas parallels that pointed out by Kollmann and Sohl (1980, p. A5) for Western Hemisphere Vernedia gastropods.

Three other species of Actaeonella-A. cubensis, A. robinsoni, and $A$. jicarensis-are of special note. They are especially distinguished by possessing two columellar plaits, which are best shown on plates 22 and 23 . The first two are rare and all are limited in distribution. Actaeonella cubensis is known only in calcareous shales of probable Maastrichtian Age from Oriente
Province, Cuba. The second species, A. robinsoni, is known from middle Maastrichtian rocks in the Guinea Corn Formation of Jamaica and the Cardenas Formation of Mexico. A. jicarensis is known from but a single locality; it occurs in exceptional abundance in limestones of the middle Maastrichtian El Rayo Formation of Puerto Rico, cooccurring with abundant nerineids.

A. duckettsensis, A. marchmontensis, and A. briggsi are endemic to single Antillean Islands. The first is the longest ranging (Campanian to middle Maastrichtian) and, although restricted to Jamaica, is found widely there. Actaeonella marchmontensis is the most common species in the Titanosarcolites-bearing limestone and shale of Jamaica. It occurs in both the Maldon Limestone and Woodland Shale of the Maldon inlier, in unnamed shales of the Marchmont inlier, and in calcareous shales of the Guinea Corn Formation of the Central inlier. Actaeonella briggsi is restricted to the Maastrichtian Revés Member of the Pozas Formation and to the El Rayo Formation, both of central Puerto Rico, and to the El Rayo Formation and Cotui Limestone of the southwestern parts of the island.

The remaining named species, $A$. coquiensis, ranges from upper Campanian to middle Maastrichtian and is known from the Coamo Formation of south-central Puerto Rico and from the Maldon Limestone and Stapleton Formations in Jamaica.

Many specimens of undetermined specific affinities are widespread in Campanian and Maastrichtian rocks of the Caribbean, Mexico, and Central America. Although poorly preserved, they do serve as a record for occurrence in such units as the Inoceramus Shales of the St. Ann's Great River inlier of Jamaica and the Maravillas Formation of Puerto Rico.

\section{LOCALITY REGISTER}

The number in the far left-hand column of the locality register (1-170) is that cited under the section labelled "occurrence" in each species description; this number is also placed in the appropriate geographic position on the locality index maps (figs. 20-25). The locality number is followed in sequence by the USGS Mesozoic (or other identified institution) collection number, the geographic locality, the stratigraphic assignment, and the collectors and date on which the collection was made.

\begin{tabular}{cc}
$\begin{array}{c}\text { USGS Mesozoic } \\
\text { colln. No. } \\
\text { (fig. 20) }\end{array}$ & $\begin{array}{c}\text { Geographic locality, stratigraphic assignment, } \\
\text { description of locality, collector's), } \\
\text { year of collection }\end{array}$ \\
\hline & PUERTO RICO \\
identified) & Barranquitas Quadrangle \\
&
\end{tabular}




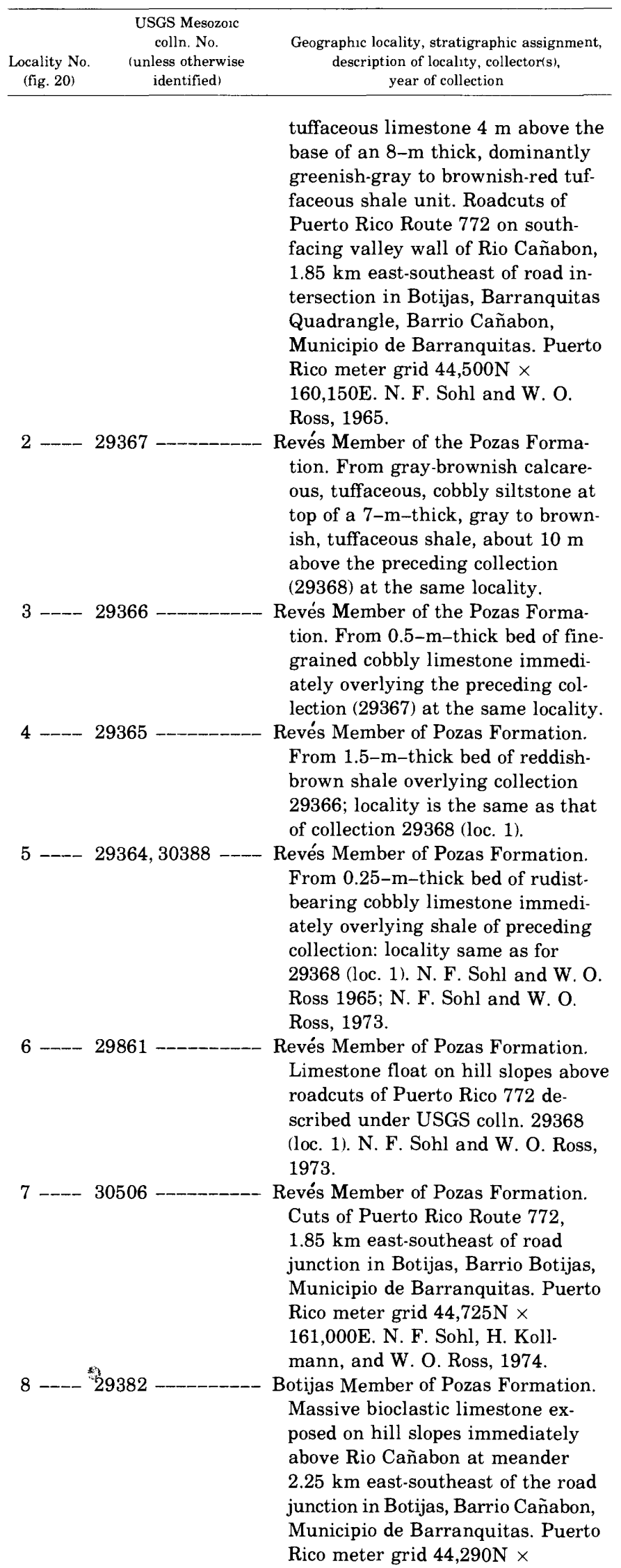

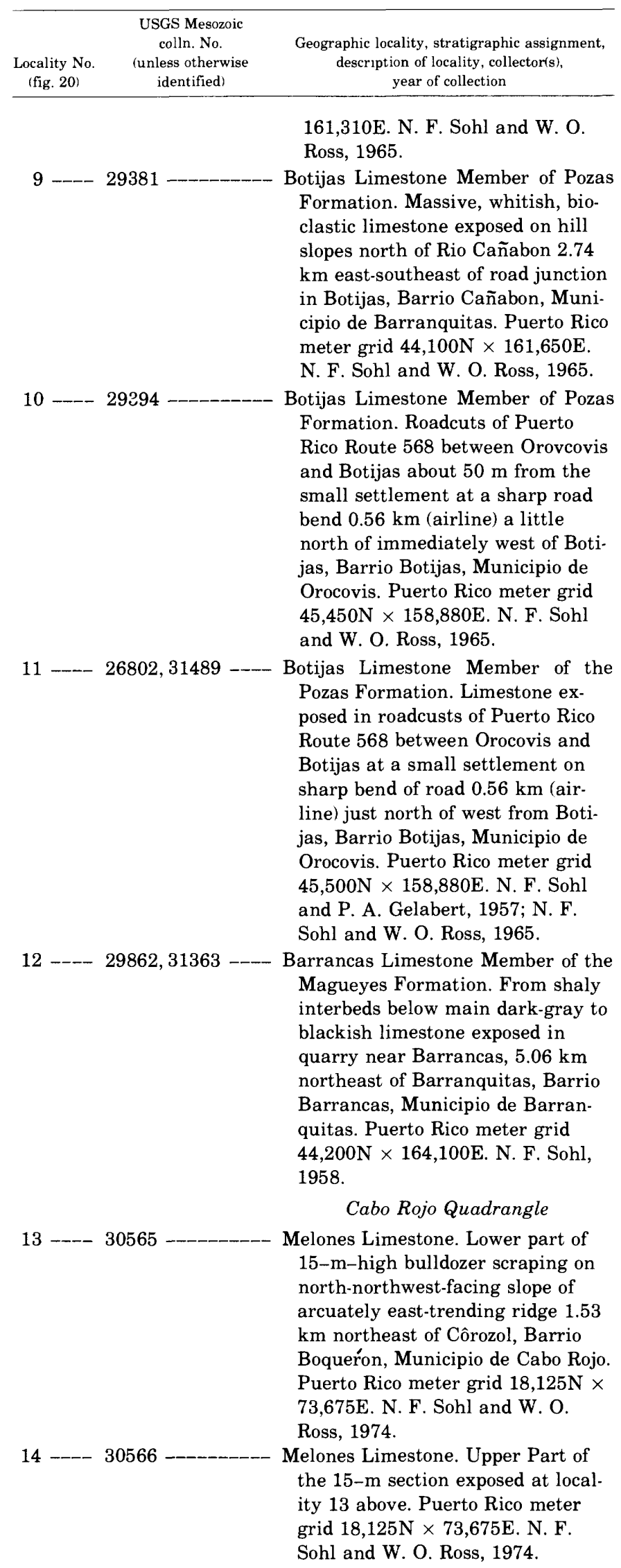




\begin{tabular}{ccc} 
& USGS Mesozoic & \\
colln. No. & Geographic locality, stratigraphic assignment, \\
Locality No. & (unless otherwise & description of locality, collector(s), \\
(fig. 20) & identified) & year of collection \\
\hline
\end{tabular}

\section{Cayey Quadrangle}

15 -_-_ 26822 -__._- Río Matón Limestone Member of the Robles Formation. Dark-gray to blackish bioclastic limestone exposed on hill slopes about $30 \mathrm{~m}$ above and $61 \mathrm{~m}$ east of Puerto Rico Route 1, 2.74 km (airline) west-southwest of Cayey Plaza, Barrio Pedro Avila, Municipio de Cayey. Puerto Rico meter grid $29,920 \mathrm{~N} \times 178,300$ E. N. F. Sohl and P. A. Gelabert, 1957.

\section{Central Aguirre Quadrangle}

16 -__ 26393, 29090 -__- Coamo Formation. Shale exposed in $30358 \quad$ gullies above abandoned quarry about 10 to $14 \mathrm{~m}$ above road level at southeastern end of elliptical hill $0.88 \mathrm{~km}$ north-northwest of Puerto Rico 3 and the CoquiCentral Aguirre road, Barrio Aguirre, Municipio de Salinas. Puerto Rico meter grid $16,075 \mathrm{~N} \times$ 173,375E. H. L. Berryhill, 1956; N. F. Sohl, P. A. Gelabert, and H. L. Berryhill, 1957; N. F. Sohl and E. G. Kauffman, 1964; N. F. Sohl and W. O. Ross, 1973.

17 -__ 30359 -____ Coamo Formation. Bulldozer track taversing lower part of hill immediately above the intersection of the road circumscribing the hill and the canefield road leading south to Route 3, Barrio Aguirre, Municipio de Salinas. Puerto Rico meter grid $16,480 \mathrm{~N} \times 173,875 \mathrm{E}$. N. F. Sohl and W. O. Ross, 1973. 18 -___ 30541 -_______ Coamo Formation. Shales exposed in bulldozer track along crest of hill $1.45 \mathrm{~km}$ northwest of intersection of Coqui-Central Aguirre road and Puerto Rico Route 3, near the 76-m summit. Barrio Aguirre, Municipio de Salinas. Puerto Rico meter grid $16,410 \mathrm{~N} \times 173,100 \mathrm{E}$ N. F. Sohl, H. A. Kollmann and W. O. Ross, 1974.

\section{Coamo Quadrangle}

19 _-_-_ 26834 -_aravillas Formation. Exposures of conglomerate in upper $106.75 \mathrm{~m}$ of formation. Roadcut of Puerto Rico Route 14 , about $1.609 \mathrm{~km}$ a little north of east of Coamo and immediately south of Rio Cayon, Barrio Palmarejo, Municipio de Coamo. Puerto Rico meter grid 27,900N $\times$ 162,000 E. N. F. Sohl and P. A. Gelabert, 1957.

\begin{tabular}{ccc}
\hline & USGS Mesozoic & \\
colln. No. & Geographic locality, stratigraphic assignment, \\
Locality No. & (unless otherwise & description of locality, collector(s), \\
(fig. 20) & identified) & year of collection \\
\hline
\end{tabular}

20 $-26841$

21 _-_ 26845 -____ Maravillas Formation. Cobbly Limestone (about $800 \mathrm{~m}$ below top of formation) exposed at base of hill $0.27 \mathrm{~km}$ a little north of east of preceding (26841) locality. Puerto Rico meter grid $23,300 \times 161,960 \mathrm{E}$. L. Glover and N. F. Sohl, 1957.

\section{Florida Quadrangle}

22 ____ 28629 _________ Flor de Alba Limestone Lentil of Pozas Formation. Roadcut near top of hill $0.48 \mathrm{~km}$ east of Hacienda Penonales, Barrio Pesas, Municipio de Ciales. Puerto Rico meter grid $51,500 \mathrm{~N} \times 144,400 \mathrm{E}$. N. F. Sohl and Arthur Nelson, 1962.

23 ___ 28742 _________ Flor de Alba Limestone Lentil of Pozas Formation. Exposure along secondary road $0.77 \mathrm{~km}$ west of Hacienda Flor de Alba, Barrio Cialitos, Municipio de Ciales. Puerto Rico meter grid 28,742N $\times$ 143,025E. N. F. Sohl and Arthur Nelson, 1962.

24 -__ 29372 ______-_ Flor de Alba Limestone Lentil of Pozas Formation. Limestones exposed in roadcuts and hill slope, north of sinkholes west of Hacienda Flor de Alba, Barrio Cialitos, Municipio de Ciales. Puerto Rico meter grid 50,300 to $50,500 \mathrm{~N} \times$ 142,900 to 143,300 E. N. F. Sohl and W. O. Ross, 1965.

\section{Orocovis Quadrangle}

25 __ 28830, 29099 - _ Río Bauta Member of the Pozas Formation (near base of member). Roadcuts of Puerto Rico Route $157,1.29 \mathrm{~km}$ (airline) from crossing of the Rio Bauta, exposures of a calcareous, tuffaceous sand below a sequence of welded tuff. Barrio Damian Abajo, Municipio de Orocovis. N. F. Sohl, 1963; N. F. Sohl and E. G. Kauffman, 1965.

26 ____ 29383,30532____ Río Bauta Member of Pozas Formation. Collections from float in scraped areas along Puerto Rico Route 157 derived from the same 


\begin{tabular}{|c|c|c|}
\hline $\begin{array}{l}\text { Locality No. } \\
\text { (fig. 20) }\end{array}$ & $\begin{array}{l}\text { USGS Mesozoic } \\
\text { colln. No. } \\
\text { (unless otherwise } \\
\text { identified) }\end{array}$ & $\begin{array}{c}\text { Geographic locality, stratigraphic assignment, } \\
\text { description of locality, collector(s), } \\
\text { year of collection }\end{array}$ \\
\hline
\end{tabular}

27 28831 30534

$$
28
$$

29 28617

30 28618

31 -- 27014, 29087 30535 beds as 28830 at the same location. N. F. Sohl and W. O. Ross, 1965; N. F. Sohl, H. A. Kollmann, and W. O. Ross, 1973.

Río Bauta Member of the Pozas Formation. (near base of member). Roadcuts of Puerto Rico Route $157,1.29 \mathrm{~km}$ (airline) from crossing of the Rio Bauta, 0.5-m-thick tuffaceous limestone rubble bed containing Barrettia, $3 \mathrm{~m}$ above the Trochactaeon-bearing tuffaceous sand bed of 28830 . Barrio Damian Abajo, Municipio de Orocovis. N. F. Sohl, 1963.

Río Bauta Member (upper part) of the Pozas Formation. Collection from brown, tuffaceous, silty shale exposed in lower part of a bulldozed track on the east-facing slope of a north-northeast-trending ridge overlooking the Rio Bauta and just north of bridge of Puerto Rico Route 158. Puerto Rico meter grid $44,900 \mathrm{~N} \times 150,300$ E. N. F. Sohl, H. A. Kollmann, and W. O. Ross, 1974.

Sabana Hoyos Limestone Member of the Maravillas Formation. Exposures in roadcuts on Puerto Rico $4.75 \mathrm{~km}$ (airline) south-southeast of junction with Rico Route 143 . Barrio Pedro Garcia, Municipio de Coamo. Puerto Rico meter grid $32,725 \mathrm{~N} \times 157,250$ E. N. F. Sohl and R. P. Briggs, 1962.

Sabana Hoyos Limestone Member of the Maravillas Formation. Roadcuts of Puerto Rico Route 151 about $300 \mathrm{~m}$ south of Ortiga, Barrio Hato Puerco Arriba, Municipio de Villalba. Puerto Rico meter grid $36,700 \mathrm{~N} \times 150,700 \mathrm{E}$. N. F. Sohl and R. P. Briggs, 1962.

\section{Puerto Real Quadrangle}

Melones Limestone. West-facing slopes of low hill just north of secondary road, $3.54 \mathrm{~km}$ (airline) south-southwest of Las Arenas, Barrio Boqueron, Municipio de Cabo Rojo. Puerto Rico meter grid $18,525 \mathrm{~N} \times 74,750 \mathrm{E}$. N. F. Sohl and R. P. Briggs, 1957; N. F. Sohl, 1963; N. F. Sohl, H. A. Kollmann and W. O. Ross, 1974.

Melones Limestone. Crest and slopes of $40-\mathrm{m}$-high hill, $3.78 \mathrm{~km}$ (airline) southwest of Las Arenas, Route 155 (at bench mark 595.3)

\begin{tabular}{ccc} 
& USGS Mesozoic & \\
colln. No. & Geographic locality, stratigraphic assignment, \\
Locality No. & (unless otherwise & descrion of locality, collector(s), \\
(fig. 20) & identified) & year of collection \\
\hline
\end{tabular}

Barrio Boqueŕon, Municipio de Cabo Rojo. Puerto Rico meter grid $18,700 \mathrm{~N} \times 73,275 \mathrm{E}$. N. F. Sohl, H. A. Kollmann, and W. O. Ross, 1974.

33 -__ 29079, 29354 -__ Melones Limestone. Low exposures along cattle run (abandoned farm road) $3.22 \mathrm{~km}$ south-southeast of Las Arenas, Barrio Llanos Costa. Puerto Rico meter grid $18,580 \mathrm{~N} \times$ 74,875 E. N. F. Sohl, $1963 ;$ N. F. Sohl and W. O. Ross, 1966.

Rio Descalabrado Quadrangle

34 -__ 27611 -_____-_ Maravillas Formation (upper part). Exposures near secondary (field) road, $2.17 \mathrm{~km}$ (airline) northnorthwest of Dscalabrado, Barrio Rio Cañas Abajo, Municipio de Juana Diaz. Puerto Rico meter grid $20,450 \mathrm{~N} \times 151,480 \mathrm{E}$. Peter Mattson, 1959.

35 -_- 27612 -_ Maravillas Formation (upper part). Exposures of limestone low on hill slopes, $2.33 \mathrm{~km}$ (airline) northnorthwest of Descalabrado, Barrio Rio Cañas Abajo, Municipio de Juana Diaz. Puerto Rico meter grid $20,650 \mathrm{~N} \times 151,640 \mathrm{E}$. Peter Mattson, 1959.

Sabana Grande Quadrangle

36 2866428748 29075,29088

38 30510
Limestone within El Rayo Formation. Saddle and gullies below crest of 125-m-high hill east of Quebrada Jicara, $4.75 \mathrm{~km}$ southwest of Sabana Grande, Barrio Lajas Arriba, Municipio de Lajas. Puerto Rico meter grid 23,900N $\times$ 93,400 to 93,600 E. N. F. Sohl and Peter Mattson, 1963; N. F. Sohl, 1963; N. F. Sohl and E. G. Kauffman, 1964.

37 -_- 30544 --_--_-_ Limestone within El Rayo Formation. Near crest of $147-m$-high hill $0.88 \mathrm{~km}$ north-northwest of Las Guaras School and west of Puerto Rico Route 328, Barrio Rayo, Municipio de Sabana Grande. Puerto Rico meter grid 25,825N × 94,725E. N. F. Sohl, H. A. Kollmann, and W. O. Ross, 1974.

San German Quadrangle

Basal part of Cotui Limestone. From a cobbly but nerineid-rich shaly limestone exposed on hill crest and southeast-facing slope to southeast of the Palmarejo to Lajas road (Puerto Rico Route 101) $1.09 \mathrm{~km}$ northeast of school at Pal- 


\begin{tabular}{|c|c|c|}
\hline $\begin{array}{l}\text { Locality No. } \\
\text { (fig. 20) }\end{array}$ & $\begin{array}{l}\text { USGS Mesozoic } \\
\text { colln. No. } \\
\text { (unless otherwise } \\
\text { identified) }\end{array}$ & $\begin{array}{c}\text { Geographic locality, stratigraphic assignment, } \\
\text { description of locality, collector(s), } \\
\text { year of collection }\end{array}$ \\
\hline
\end{tabular}

marejo, Barrio Sabana Yeguas, Municipio de Lajas. Puerto Rico meter grid $23,800 \mathrm{~N} \times 85,025 \mathrm{E}$. N. F. Sohl, H. A. Kollmann, and W. O. Ross, 1974.

39 ___ 30512 -____ Basal part of Cotui Limestone. From a $0.3-m$-thick bed of brown silty shale containing a concentration of Trochactaeon woodsi (Rennie), $2.4 \mathrm{~m}$ above the limestone of 30510 (preceding locality). N. F. Sohl, H. A. Kollmann, and W. O. Ross, 1974.

40 -__ 30347 - Cotui Limestone. Collection from float near base of small limestone knob rising through the alluvium of the Lajas Valley and amidst a cluster of houses along a secondary road about $300 \mathrm{~m}$ east of junction with Puerto Rico Route 116, about $1.61 \mathrm{~km}$ (airline) southsoutheast of Lajas, Barrio Sabana Yeguas, Municipio de Lajas. Puerto Rico meter grid $22,790 \mathrm{~N} \times$ 87,140 E. N. F. Sohl and W. O. Ross, 1973.

41 -_-_ 30350 -_____ Cotui Limestone. Locality same as preceding (30347), but from massive gray bioclastic limestone near the top of the hillock. N. F. Sohl and W. O. Ross, 1973.

42 ___ 31488 -_____ Limestone cobbles in tuffs of the El Rayo Formation, $5.63 \mathrm{~km}$ southeast of San German, Barrio Lajas Arriba, Municipio de Lajas. Puerto Rico meter grid $22,560 \mathrm{~N} \times$ 89,700E. Peter Mattson, 1955.

43 -_-_ 30343 _-_.____ Erratic block of silicified limestone in brecia of the Sabana Grande Formation. Exposures along foot trail about $2.73 \mathrm{~km}$ northeast of $\mathrm{El}$ Brujo, Barrio Tuna, Municipio de San German. Puerto Rico meter grid $26,300 \mathrm{~N} \times 82,025 \mathrm{E}$. Peter Mattson, 1955.

44 -__ 30315 -_____ Lower part of Cotui Limestone. Roadcuts at end of paved road $2.22 \mathrm{~km}$ north of Llanos intersection, Barrio Paris, Municipio de Lajas. Puerto Rico meter grid $24,225 \mathrm{~N} \times$ 81,195 E. N. F. Sohl and W. O. Ross, 1974.

45 -_ 30514 - Lower part of Cotui Limestone. Hill slopes north of Puerto Rico Route $312,2.22 \mathrm{~km}$ north of El Brujo, Barrio Monte Grande, Municipio de Cabo Rojo. Puerto Rico meter grid $26,480 \mathrm{~N} \times 80,000 \mathrm{E}$. N. F. Sohl and W. O. Ross, 1974.

\begin{tabular}{|c|c|c|}
\hline $\begin{array}{l}\text { Locality No. } \\
\text { (fig. 20) }\end{array}$ & $\begin{array}{l}\text { USGS Mesozoic } \\
\text { colln. No. } \\
\text { (unless otherwise } \\
\text { identified) }\end{array}$ & $\begin{array}{c}\text { Geographic locality, stratigraphic assignment, } \\
\text { description of locality, collector(s), } \\
\text { year of collection }\end{array}$ \\
\hline
\end{tabular}

46 - 30516 -____ Lower part of the Cotui Limestone. Limestone exposures in field adjacent to road and hill slopes opposite intersection with dirt track to west, $1.89 \mathrm{~km}$ north-northeast of intersection of Puerto Rico Routes 306 and 4 at Llanos, Barrio Paris, Municipio de Lajas. Puerto Rico meter grid $23,925 \mathrm{~N} \times 81,050 \mathrm{E}$. N. F. Sohl and W. O. Ross, 1974.

47 -_- 30518 -__-_ Top of Cotui Limestone. Path and field adjacent to jeep trail, 2.57 $\mathrm{km}$ south-southeast of road intersection in Monte Grande, Barrio Tuna, Municipio de San German. Puerto Rico meter grid $26,150 \mathrm{~N} \times$ 81,980 E. N. F. Sohl, R. P. Volckmann, and W. O. Ross, 1974.

48 -_ 30354 -___ Limestone within the El Rayo Formation. Northeast-facing slopes of 46-m-high hill in canefields east of farm road, $1.20 \mathrm{~km}$ west-southwest of road junction in Lajas Arriba, Barrio Lajas Arriba, Municipio de Lajas. Puerto Rico meter grid $22,725 \mathrm{~N} \times 90,050$ E. N. F. Sohl and W. O. Ross, 1973.

49 _.__ 27090 -______ Limestone within El Rayo Formation. Slopes and quarry at base of triangular east-trending elongate hill (altitude $25-30 \mathrm{~m}$ ), about 0.24 $\mathrm{km}$ north of Parada de Senal Irizarry, Barrio Lajas Arriba Municipio de Lajas. N. F. Sohl and R. P. Briggs, 1956.

49a -_- 31488 -_______ El Rayo Formation. From limestone cobbles in tuff about $5.63 \mathrm{~km}$ southeast of San German. Puerto Rico meter grid $22,560 \mathrm{~N} \times$ 89,700E. Peter Mattson, 1954.

50 -_- 30364 -_____-_ Limestone within the El Rayo Formation. Collection from a $0.3-\mathrm{m}-$ thick, cobbly, shaly limestone 17.4 $\mathrm{m}$ above base of section exposed in a quarry about $300 \mathrm{~m}$ north of road that follows Antigua via del Ferrocarril north of Parada de Senal Irizarry and $1.5 \mathrm{~km}$ airline west-southwest of road junction at Lajas Arriba. Puerto Rico meter grid $22,550 \mathrm{~N} \times 89,750 \mathrm{E}$. N. F. Sohl and W. O. Ross, 1973.

51 -_- 30367, 30526-_-- Locality same as preceding but from a thin shale interbedded with limestone $49.5 \mathrm{~m}$ above base of section exposed in quarry. N. F. Sohl and W. O. Ross, 1973 and 1974. 


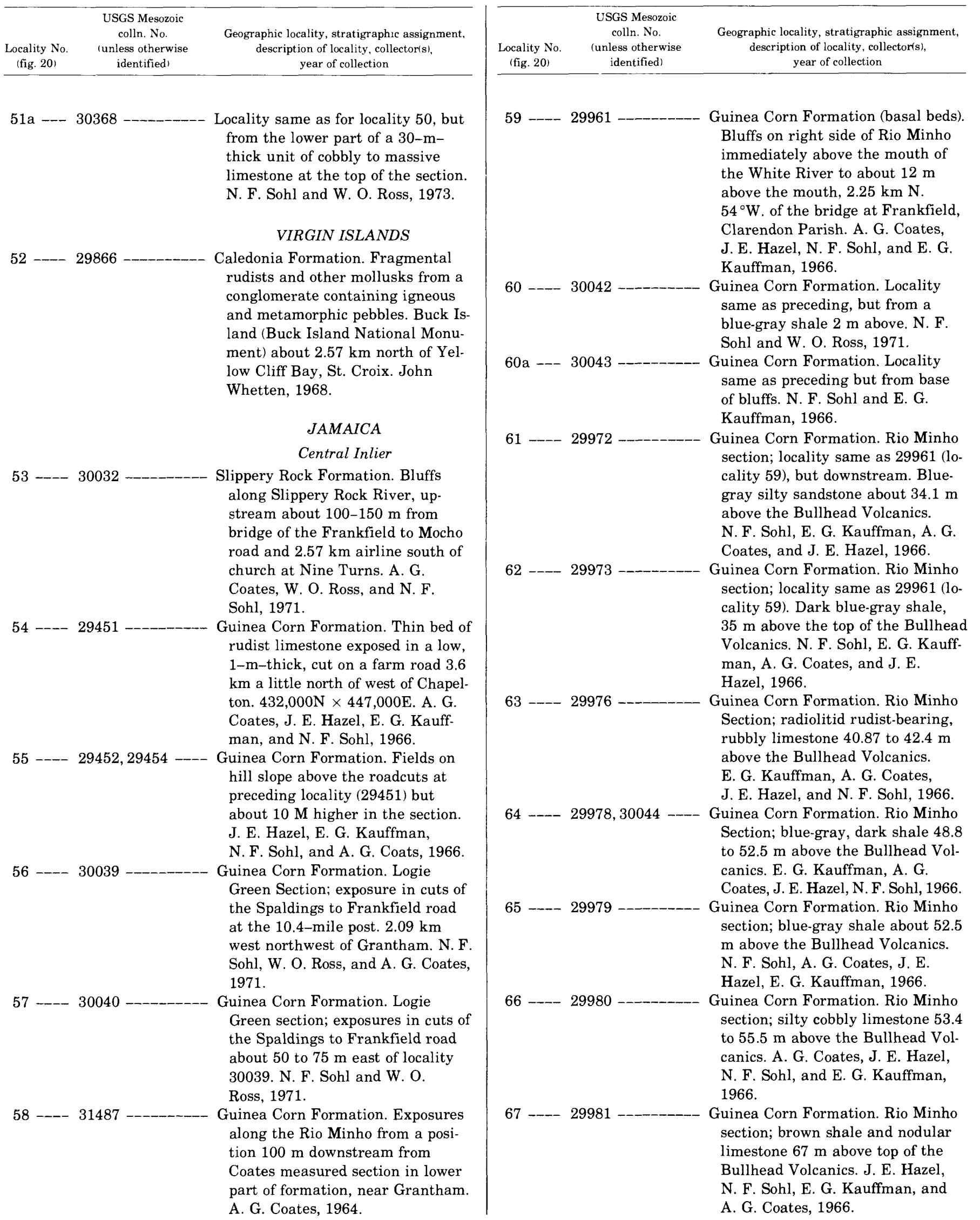




\begin{tabular}{ccc} 
& USGS Mesozoic & colln. No. \\
$\begin{array}{c}\text { Locality No. } \\
\text { (fig. 20) }\end{array}$ & $\begin{array}{c}\text { Geographic locality, stratigraphic assignment, } \\
\text { identified) }\end{array}$ & $\begin{array}{c}\text { description of locality, collector(s), } \\
\text { year of collection }\end{array}$ \\
\hline
\end{tabular}

68 - 29982 -______ Guinea Corn Formation. Exposure of gray silty shale in banks of the Rio Minho, $67.3 \mathrm{~m}$ above the base of the formation at same locality (59) as 29961. A. G. Coates, J. E. Hazel, N. F. Sohl, and E. G. Kauffman, 1966

68a -_- 29985 -____-_ Guinea Corn Formation. Limestone containing volcanic pebbles $70.1-$ $74.7 \mathrm{~m}$ above the base of the formation at same locality (59) as 29961. N. F. Sohl, J. E. Hazel, E. G. Kauffman, and A. G. Coates, 1966.

69 -___ 29987 -_______nea Corn Formation. Massive limestone exposed in banks of the Rio Minho $76.2 \mathrm{~m}$ above the base of the formation at same locality (59) as 29961. J. E. Hazel, E. G. Kauffman, N. F. Sohl, and A. G. Coates, 1966.

70 ____ 29988 -______uinea Corn Formation. Blue-gray shale in banks of Rio Minho, $82.3 \mathrm{~m}$ above base of formation at same locality (59) as 29961 . N. F. Sohl, E. G. Kauffman, A. G. Coates, and J. E. Hazel, 1966.

71 -_ 29989 -____ Guinea Corn Formation. Interbedded cobbly limestone and shale exposed in banks of the Rio Minho 82.9-85.9 $\mathrm{m}$ above the base of the formation at same locality (59) as 29961. E. G. Kauffman, J. E. Hazel, A. G. Coates, and N. F. Sohl, 1966

72 -__ 29990 -______ Guinea Corn Formation. Chiapasellarich limestone exposed in banks of the Rio Minho about $87.8 \mathrm{~m}$ above base of the formation at same locality (59) as 29961 . N. F. Sohl, 1966.

73 -_- 30050 -_____ Guinea Corn Formation. From near base of 6.3-m-thick light-gray limestone $6.7 \mathrm{~m}$ below the contact with the volcanic rocks of the Summerfield Formation exposed in banks of the Rio Minho, $2 \mathrm{~km} \mathrm{~N}$. $30^{\circ} \mathrm{W}$. of Frankfield Post Office. N. F. Sohl and W. O. Ross, 1971.

74 -__ 30054 -_____-_ Guinea Corn Formation. From middle part of the 19.8-m unit of interbedded cobbly limestone and massively bedded radiolite limestone, 59.8 to $79.6 \mathrm{~m}$ below the Summerfield Formation at same locality (73) as 30050 . N. F. Sohl and W. O. Ross, 1971.

75 -_ 30058 Guinea Corn Formation. From 0.6-m shale about $82.6 \mathrm{~m}$ below the Summerfield Formation exposed

\begin{tabular}{|c|c|c|}
\hline $\begin{array}{l}\text { Locality No. } \\
\text { (fig. 20) }\end{array}$ & $\begin{array}{c}\text { USGS Mesozoic } \\
\text { colln. No. } \\
\text { (unless otherwise } \\
\text { identified) }\end{array}$ & $\begin{array}{c}\text { Geographic locality, stratigraphic assignment, } \\
\text { description of locality, collector(s), } \\
\text { year of collection }\end{array}$ \\
\hline
\end{tabular}

in banks of the Rio Minho at same locality (73) as 30050 . N. F. Sohl and W. O. Ross, 1971.

76 -_-_ 30056 -____-_ Guinea Corn Formation From a $0.9-\mathrm{m}$ shale, $81.4 \mathrm{~m}$ below the Summerfield Formation exposed in banks of the Rio Minho at same locality (73) as 30050 . N. F. Sohl and W. O. Ross, 1971.

77 ____ 30061 -_______ Guinea Corn Formation. Exposures in streambed and banks of the Rio Minho $2.3 \mathrm{~km} \mathrm{~N}$. $30^{\circ} \mathrm{W}$. of Frankfield Post Office, Clarendon Parish. Collection from a 2.4-m-thick blue-gray shale, about $76 \mathrm{~m}$ above the base of formation. N. F. Sohl and W. O. Ross, 1971.

78 -__ 30141 -_______ Guinea Corn Formation. Locality same as that for 30061 (loc. 77) but from a cobbly radiolite-rich shale about $73.3 \mathrm{~m}$ above base of formation. N. F. Sohl and W. O. Ross, 1971.

79 -_- 30063 -_____ Guinea Corn Formation. Locality same as that for 30061 (loc. 77), but from a brownish hackly shale about $70.73 \mathrm{~m}$ above base of formation. N. F. Sohl and W. O. Ross, 1971.

80 ___ 18011 _._____ Guinea Corn Formation. Near second outcrop of rudist limestone, 16.9 to $17.3 \mathrm{~km}$ from Spaldings. Soft yellow calcareous marl full of rudists, together with corals, decapod crustacean fragments, mollusks, etc. Logie Green road, faulted against red shales, Middlesex County, Clarendon Parish, Jamaica. C. A. Matley, 1939.

81 -__ 18014 -___ Guinea Corn Formation. Rudist marls, very fossiliferous Logie Green section, 17.7 to $19.3 \mathrm{~km}$ from Spaldings, Middlesex County, Clarendon Parish, Jamaica. C. R. Matley, 1939.

82 -__- 18016 -_______ Guinea Corn Formation. Logie Green section, continuation of 18014 beds containing more rudists, Middlesex County, Clarendon Parish, Jamaica. C. A. Matley, 1939.

83 ____ 18017 _________ Guinea Corn Formation. "Bad Rock," nodular rudist beds, slipping over solid limestone. Logie Green section, 17.7 to $19.3 \mathrm{~km}$ from Spaldings, at embanked area at a bend above Rio Minho, Middlesex County, Clarendon Parish. C. A. Matley, 1939. 


\begin{tabular}{|c|c|c|}
\hline $\begin{array}{l}\text { Locality No. } \\
\text { (fig. 20) }\end{array}$ & $\begin{array}{l}\text { USGS Mesozoic } \\
\text { colln. No. } \\
\text { (unless otherwise } \\
\text { identified) }\end{array}$ & $\begin{array}{c}\text { Geographic locality, stratigraphic assignment, } \\
\text { description of locality, collector(s), } \\
\text { year of collection }\end{array}$ \\
\hline
\end{tabular}

84 -_- 18019 -____ Guinea Corn Formation. Horizon probably high in rudist limestone. Logie Green section, beyond tuffs at 12-mile post, Middlesex County, Clarendon Parish. C. A. Matley, 1939.

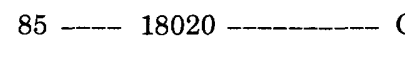

Guinea Corn Formation. Nodular marly clays or marl with rudists (slipping). Logie Green Section, 19.3 to $20.9 \mathrm{~km}$ from Spaldings, Middlesex County, Clarendon Parish. C. A. Matley, 1939.

86 - 18023 -_____ Guinea Corn Formation. Nodular limestone interbedded with marl, and shale, containing small rudists. Logie Green Section on road to Spaldings, at Grantham, near but before the crossing of the White Rock River, at near road level, Middlesex County, Clarendon Parish. C. A. Matley, 1939.

87 -_- 18024 -___-_ Guinea Corn Formation. On path rising above the preceding locality and at a higher stratigraphic level, Logie Green section, Middlesex County, Clarendon Parish. C. A. Matley, 1939.

88 -_- 18029 -__- Guinea Corn Formation. Top beds of rudist limestone. White Rock River Road about $300 \mathrm{~m}$ before 3mile post, Middlesex County, Clar endon Parish. C. A. Matley, 1939.

89 - 18031 - Guinea Corn Formation. Gastropod bed $7.2 \mathrm{~cm}$ thick exposed along the Frankfield-Trout Hall Road, at $28.6 \mathrm{~km}$, Middlesex County, Clarendon Parish, Jamaica. C. A. Matley, 1939.

90 - - 18033 -____- Guinea Corn Formation. Rudist limestone. Content Gully, Frankfield, Middlesex County. C. A. Matley, 1939.

91 -_- 18034 -_-_-_ Guinea Corn Formation. Shale containing thin calcareous layers below rudist limestone. Above left bank of stream, carbonized plant remains, small oysters, tiny mollusks, etc. Content Gully, Frankfield, Middlesex County. C. A. Matley, 1939.

\section{Marchmont Inlier}

92 ___ 29924, 30028 _-_Titanosarcolites limestone." Lower $1.6 \mathrm{~m}$ of section in shaly, cobbly limestone exposed at a hairpin bend of the Ducketts to Greenwich road $0.32 \mathrm{~km}$ airline $\mathrm{E} .20^{\circ} \mathrm{N}$. of Ducketts Crossroads, Ducketts land Settlement, Westmoreland

\begin{tabular}{ccc} 
& USGS Mesozoic & \\
colln. No. & Geographic locality, stratigraphic assignment, \\
Locality No. & (unless otherwise \\
(fig. 20) & identified) & $\begin{array}{c}\text { year of collection } \\
\text { yention of locality, collector(s), }\end{array}$ \\
\hline
\end{tabular}

Parish, $18^{\circ} 17^{\prime} 47^{\prime \prime N}$., $77^{\circ} 54^{\prime} 54^{\prime \prime} \mathrm{W}$. N. F. Sohl, E. G. Kauffman, A. G. Coates, and J. E. Hazel, 1966; W. O. Ross, A. G. Coates, and N. F. Sohl, 1971.

93 -_-_ 29925, 30027 -_-_ "Titanosarcolites limestone." Locality same as preceding but from the middle of a $0.7-\mathrm{m}$ unit of yellowish shale overlying the shaly limestone of the preceding. N. F. Sohl, E. G. Kauffman, A. G. Coates, and J. E. Hazel, 1966; N. F. Sohl, W. O. Ross, and A. G. Coates, 1971. 94 ___ 29926 _______ "Titanosarcolites limestone." Locality same as 29924 (loc. 92) but from $1.3-\mathrm{m}$ radiolite limestone bed overlying preceding locality (29925). N. F. Sohl, E. G. Kauffman, A. G. Coates, and J. E. Hazel, 1966.

95 -_-_ 29927 -_______ "Titanosarcolites limestone." Float in fields on hillslope below 29924 (loc. 92), $0.32 \mathrm{~km} \mathrm{W.30}{ }^{\circ} \mathrm{N}$. of Ducketts Crossroads, Ducketts Land Settlement, Westmoreland Parish, $18^{\circ} 17^{\prime} 49^{\prime \prime}$ N., $77^{\circ} 54^{\prime} 53^{\prime \prime} \mathrm{W}$. E. G. Kauffman, A. G. Coates, J. E. Hazel, and N. F. Sohl, 1966.

96 _-_ 29921 _-_ Titanosarcolites limestone." From a 5-m-thick, gray cobbly limestone $32 \mathrm{~m}$ above a brownish shale in a section measured from edge of banana field and directly up hill slope to road level $0.48 \mathrm{~km}$ (airline) northeast of Ducketts Crossroads, $18^{\circ} 17^{\prime} 54^{\prime \prime} \mathrm{N}$., $77^{\circ} 54^{\prime} 57^{\prime \prime} \mathrm{W}$. A. G. Coates, J. E. Hazel, N. F. Sohl, and E. G. Kauffman, 1966.

97 -_- 30026 -_______ "_tanosarcolites limestone." Reddishbrown shale exposed in cuts of the Cambridge to Lambs River road at Ducketts Crossroads, $2.17 \mathrm{~km}$ (airline) south-southeast of the railroad station in Cambridge, $18^{\circ} 17^{\prime} 43^{\prime \prime} \mathrm{N}$., $77^{\circ} 54^{\prime} 46^{\prime \prime}$ W. N. F. Sohl, W. O. Ross, and A. G. Coates, 1971.

98 -_-_ 30030 -__-__-_ "Titanosarcolites limestone." Exposures of calcareous sandstone on north bank of east-flowing tributary of Great River west of Lambs River road, $0.97 \mathrm{~km}$ south of Duck. etts Crossroads, Westmoreland Parish, $18^{\circ} 17^{\prime} 12^{\prime \prime}$ N., $77^{\circ} 54^{\prime} 43^{\prime \prime} \mathrm{W}$. W. O. Ross, A. G. Coates, and N. F. Sohl, 1971.

99 _-_- 30462 -______ "Titanosarolites limestone." St. Leonard to Seafordtown road, 0.56 $\mathrm{km}$ northeast (airline) of Seafordtown junction, Westmoreland Parish, $18^{\circ} 14^{\prime} 59^{\prime \prime} \mathrm{N}$., $77^{\circ} 53^{\prime} 55^{\prime \prime} \mathrm{W}$. 


\begin{tabular}{ccc} 
& USGS Mesozoic & \\
colln. No. & Geographic locality, stratigraphic assignment, \\
(unless otherwise & description of locality, collector(s), \\
(fig. 20) & identified) & year of collection \\
\hline
\end{tabular}

"Titanosarcolites limestone." From upper part of 6.5-m-thick unit of gray shale below a $1.5-\mathrm{m}$-thick radiolite limestone exposed in cuts of the St. Leonards to Marchmont road at the south edge of Marchmont, or $0.16 \mathrm{~km}$ (airline) south of the road intersection in Marchmont, $18^{\circ} 15^{\prime} 34^{\prime \prime} \mathrm{N}$., $77^{\circ} 52^{\prime} 53^{\prime \prime} \mathrm{W}$. N. F. Sohl and E. G. Kauffman, 1972.

101 -_-_ 30460 -_____ Shales below "Titanosarcolites limestone." Exposures of reddish-brown shale that overlie brownish sand in cuts of Lambs River to Seafordtown road, $1.45 \mathrm{~km}$ (airline) northwest of Lambs River, Westmoreland Parish, $18^{\circ} 15^{\prime} 02^{\prime \prime} \mathrm{N}$., $77^{\circ} 54^{\prime} 30^{\prime \prime} \mathrm{W}$. E. G. Kauffman and N. F. Sohl, 1972.

102 __ 30456 _________ "Titanosarcolites limestone" Expo sures in cuts of the Lambs River to Marchmont road, $1.5 \mathrm{~km}$ (airline) north-northeast of Lambs River. Collection from a 3-m-thick gray silty shale $6 \mathrm{~m}$ above the base of the section, $18^{\circ} 16^{\prime} 24^{\prime \prime} \mathrm{N}$., $77^{\circ} 54^{\prime} 46^{\prime \prime}$ W. N. F. Sohl and E. G. Kauffman, 1971.

102a --- 30457 -_-__-_ Locality same as loc. 102 (30456), but from a $1.5-\mathrm{m}$-thick shale $11 \mathrm{~m}$ above base of section. N. F. Sohl and E. G. Kauffman, 1971.

103 _-_ 30471 _____ "Titanosarcolites limestone." Seafordtown to Chesterfield Bridge road, $0.93 \mathrm{~km}$ (airline) south of Seafordtown road junction. Collection from 2-m-thick brownishgray shale, $3 \mathrm{~m}$ above base of section, $18^{\circ} 14^{\prime} 18^{\prime \prime} \mathrm{N}$., $70^{\circ} 53^{\prime} 52^{\prime \prime} \mathrm{W}$. E. G. Kauffman and N. F. Sohl, 1972.

104 -_-_ 30472 _________ "Titanosarcolites limestone." Locality same as for 30471, but from a 1.5m-thick brownish clay containing abundant corals, $5 \mathrm{~m}$ above base of section. N. F. Sohl and E. G. Kauffman, 1972.

105 _-_ 30473 -___ "Titanosarcolites limestone." Locality same as that for 30471 (loc. 103), but from a 6-m-thick nodular to cobbly gray radiolite-coral-rich limestone that caps the section. E. G. Kauffman and N. F. Sohl, 1972.

105a -_- 30476 -_______ "Titanosarcolites limestone." Bluff along right bank of east-flowing tributary of Great River immedi-

\begin{tabular}{|c|c|c|}
\hline $\begin{array}{l}\text { Locality No. } \\
\text { (fig. 20) }\end{array}$ & $\begin{array}{l}\text { USGS Mesozoic } \\
\text { colln. No. } \\
\text { (unless otherwise } \\
\text { identified) }\end{array}$ & $\begin{array}{c}\text { Geographic locality, stratigraphic assignment, } \\
\text { description of locality, collector(s), } \\
\text { year of collection }\end{array}$ \\
\hline
\end{tabular}

ately west of bridge of secondary road, about $40 \mathrm{~m}$ south of Chesterfield Bridge-Seafordtown road, $18^{\circ} 13^{\prime} 50^{\prime \prime}$ N., $77^{\circ} 52^{\prime} 27^{\prime \prime}$ W. N. F. Sohl and E. G. Kauffman, 1972. 106 -_-_ 30455 -_Titanosarcolites limestone." Cuts of Ducketts to Lambs River road 1.85 $\mathrm{km}$ (airline) south of Ducketts Crossroads, $18^{\circ} 16^{\prime} 32^{\prime \prime} \mathrm{N}$., $77^{\circ} 54^{\prime} 42^{\prime \prime} \mathrm{W}$. N. F. Sohl and E. G. Kauffman, 1971.

107 -_ 30480 -______ "Titanosarcolites limestone." Brownish-gray shale exposed in stream bluff about $3 \mathrm{~m}$ above water level on right bank of tributary of the Great River, immediately west of bridge of secondary road, about $40 \mathrm{~m}$ south of the Chesterfield Bridge to Seafordtown road, $18^{\circ} 13^{\prime} 59^{\prime \prime} \mathrm{N}$., $77^{\circ} 52 ' 27^{\prime \prime} \mathrm{W}$. N. F. Sohl and E. G. Kauffman, 1971.

Jerusalem Mountain Inlier 30421

"Titanosarcolites limestone." Cobbly limestone exposed in roadcuts 1.13 $\mathrm{km}$ (airline) southeast of Jerusalem Mountain crossroads, $18^{\circ} 19^{\prime} 0^{\prime \prime} \mathrm{N}$., $78^{\circ} 13^{\prime} 32^{\prime \prime}$ W. E. G. Kauffman and N. F. Sohl, 1971.

109 -__ 30011, 30422 -__ "Titanosarcolites limestone." Exposed in roadcuts of road to Mount Eagle $1.07 \mathrm{~km}$ (airline) southeast of Jerusalem Mountain road intersection on path to Assemblage of God Church, $18^{\circ} 18^{\prime} 59^{\prime \prime} \mathrm{N}$., $78^{\circ} 13^{\prime \prime} 36^{\prime \prime} \mathrm{W}$.

W. O. Ross, A. G. Coates, and N. F. Sohl, 1971; N. F. Sohl and E. G. Kauffman, 1971.

110 -__ 29465 -________ "Titanosarcolites limestone." Roadcuts along Jerusalem Mountain to Belle Isle road, northeast of houses that sit on "oyster limestone" outcrops, about $330 \mathrm{~m}$ (airline) northeast of intersection with the Blairs Hill to Jerusalem Mountain road. $18^{\circ} 19^{\prime} 29^{\prime \prime}$ N., $78^{\circ} 13^{\prime} 14^{\prime \prime}$ W. N. F. Sohl, E. G. Kauffman, and J. E. Hazel, 1966.

111 ____ 29466 _________ "Titanosarcolites limestone." Float from covered interval in sections in roadcuts at the same locality as that for 29465 (loc. 110). E. G.

Kauffman, J. E. Hazel, and N. F. Sohl, 1966.

112 -_-_ 29467 -_ Titanosarcolites limestone." From a $0.6-\mathrm{m}$-thick rubbly limestone exposed about $3 \mathrm{~m}$ above road level at same locality as that for 


\begin{tabular}{|c|c|c|}
\hline $\begin{array}{l}\text { Locality No. } \\
\text { (fig. 20) }\end{array}$ & $\begin{array}{l}\text { USGS Mesozoic } \\
\text { colln. No. } \\
\text { (unless otherwise } \\
\text { identified) }\end{array}$ & $\begin{array}{c}\text { Geographic locality, stratigraphic assignment, } \\
\text { description of locality, collector(s), } \\
\text { year of collection }\end{array}$ \\
\hline
\end{tabular}

29465 (loc. 110). J. E. Hazel, E. G. Kauffman, and N. F. Sohl, 1966.

113 -__- 29473 -_____ "Titanosarcolites limestone." From 1-m-thick rubbly limestone about 100 m east of 29465 (loc. 110 ), about $7 \mathrm{~m}$ above base of measured section. N. F. Sohl, J. E. Hazel and E. G. Kauffman, 1966.

114 -_ 29475 massive 1-m-thick limestone unit about $7.5 \mathrm{~m}$ above base of measured section, $120 \mathrm{~m}$ east of 29465 (loc. 110). E. G. Kauffman, J. E. Hazel, and N. F. Sohl, 1966.

115 -_ 29476 cobbly limestone in shale overlying 29475 , about $8 \mathrm{~m}$ above base of measured section $120 \mathrm{~m}$ east of 29465 (loc. 110). J. E. Hazel, N. F. Sohl, and E. G. Kauffman, 1966.

\section{Maldon Inlier}

116 ___ 29953, 30023 -__- Woodland Shale. From a yellowishbrown silty clay $3 \mathrm{~m}$ above base of section and about $3.25 \mathrm{~m}$ below the Maldon Limestone. Point to Flamstead Road, $1.93 \mathrm{~km}$ (airline) north of the crossroads at Flam. stead, St. James Parish. J. E. Hazel, N. F. Sohl, E. G. Kauffman, and A. G. Coates, 1966.

117 ____ 30019 ________ Vaughansfield Limestone. Collection from float weathering out on hill slopes downslope (north) from Flamstead to Maroontown road, St. James Parish, $1.77 \mathrm{~km}$ (airline) southwest of Maroontown. A. G. Coates, W. O. Ross, and N. F. Sohl, 1971.

118 -_-_ 29951 -__-_ Maldon Limestone. Exposures titanosarcolites-rich limestone in the schoolyard of Maldon school yard, $0.21 \mathrm{~km}$ (airline) N. $74^{\circ} \mathrm{W}$. of Maroontown, St. James Parish. J. E. Hazel, N. F. Sohl, E. G., Kauffman, and A. G. Coates, 1966.

119 -_- 29955, 30017 -_- Maldon Limestone. Yellowish-brown 30018

121 30007 sured section in roadcuts and adjacent fields near Chatsworth School at Shaw Castle, $1.45 \mathrm{~km}$ (airline) N. $33^{\circ} \mathrm{W}$. of Maroontown, St. James Parish. N. F. Sohl, E. G. Kauffman; A. G. Coates, and J. E. Hazel, 1966; W. O. Ross, A. G. Coates, and N. F. Sohl, 1971.

\section{Green Island Inlier}

"Barrettia Limestone." Limestone

$\begin{array}{ccc}\text { USGS Mesozoic } & \text { colln. No. } \\ \text { Locality No. } & \begin{array}{c}\text { Geographic locality, stratigraphic assignment, } \\ \text { description of locality, collector(s), } \\ \text { (fig. 20) }\end{array} & \text { identified) }\end{array}$

north-trending valley $0.97 \mathrm{~km}$ (airline) $\mathrm{S} .40^{\circ} \mathrm{W}$. of Green Island, $18^{\circ} 22^{\prime} 49^{\prime \prime} \mathrm{N}, 78^{\circ} 16^{\prime} 49^{\prime \prime}$ W. N. F. Sohl, A. G. Coates, and W. O. Ross, 1971.

\section{Sunderland Inlier}

122 -_-_ 29939, 30014 --- Stapleton Formation. Roadcut exposures south of Stapleton on road to Kensington and from a 0.4-m-thick bed of coarse bioclastic limestone $2.4 \mathrm{~km}$ (airline) south-southeast of Sunderland Bridge, St. James Parish, $18^{\circ} 22^{\prime} 47^{\prime \prime} \mathrm{N}$., $77^{\circ} 50^{\prime} 07^{\prime \prime} \mathrm{W}$. N. F. Sohl, E. G. Kauffman, A. G. Coates, and J. E. Hazel, 1966; N. F. Sohl, W. O. Ross, and A. G. Coates, 1971.

St. Ann's Great River Inlier 123 30065

Exposures of dark-gray shale in bluffs of Saint Ann's Great River, upstream and about $100 \mathrm{~m}$ higher than the shales exposed at the ford south-southeast of St. Ann's Bay. N. F. Sohl and W. O. Ross, 1971.

\section{CUBA}

124 18283

Habana Formation? From exposures in a small unnamed creek, $1.0 \mathrm{~km}$ west of the stack of Central Perseverancia, Santa Clara Province, Emilio Aleman, date unknown.

125 - 19464, 19465 - Habana Formation? Exposures in bed of river east-southeast of house of Senor Aparicio $25.3 \mathrm{~km}$ east of Central Miranda on south bank of Rio Sumidero, Oriente, Province. G. E. Lewis, 1945.

126 - 27169 Habana Formation. $150 \mathrm{~m}$ north of (895P Palmer Grua Esperanza, which is $6 \mathrm{~km}$ Collection) east of Madruga, Habana Province. R. H. Palmer, 1942.

127 -__ 27266 -___ Habana Formation. $500 \mathrm{~m} \mathrm{S.} 20^{\circ} \mathrm{E}$. (2793 Palmer of Negrito and $8.5 \mathrm{~km}$ southCollection) southeast of Central Soledad, Sanfrom high on west-facing wall of ta Clara Province. R. H. Palmer, 1942.

128 -_- 27277 -_____ Habana Formation. El Abra, 20 km (2941 Palmer east and $6 \mathrm{~km}$ south of Central Collection) Hormiguero, Santa Clara Province. R. H. Palmer, 1942.

$129-\cdots 27278$

(2942 Palmer Collection)
Habana Formation. South slope of Loma Campana about north of Grua Campana, Central Hormiguero, Santa Clara Province. R. H. Palmer, 1942. 


\begin{tabular}{|c|c|c|}
\hline $\begin{array}{l}\text { Locality No. } \\
\text { (fig. 20) }\end{array}$ & $\begin{array}{l}\text { USGS Mesozoic } \\
\text { colln. No. } \\
\text { (unless otherwise } \\
\text { identified) }\end{array}$ & $\begin{array}{c}\text { Geographic locality, stratigraphic assignment, } \\
\text { description of locality, collectors), } \\
\text { year of collection }\end{array}$ \\
\hline
\end{tabular}

$130--27295$ (Original No. 3144)

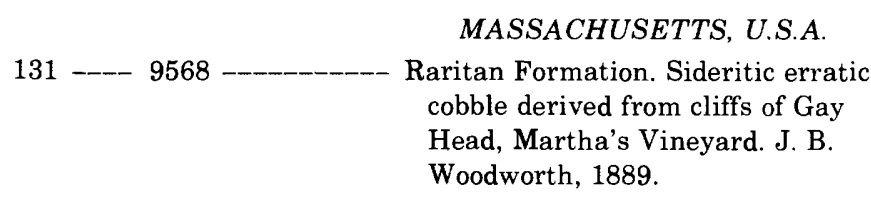

\section{TEXAS, U.S.A.}

132 _- 1632 _Caprina Limestone" (Edwards Limestone). About $9.65 \mathrm{~km}$ northeast of Kerrville on the road to Fredricksburg, Kerr County. R. T. Hill, T. W. Vaughan, and T. W. Stanton, 1895.

133 -_ 1926 south of west of Kent, Culberson County. T. W. Stanton, 1898.

134 _-_ 1941 - Devils River Limestone (upper part). Near base of box canyon about $91.5 \mathrm{~m}$ below level of the track of the G. H. and S. A. Railroad at the high bridge over the Pecos River, $4.8 \mathrm{~km}$ east of Shumla, $\mathrm{Val}$ Verde County. T. W. Stanton, 1898. 135 - 1946,18791 - - Devils River Limestone (upper part). Painted Caves on the Rio Grande River $1.6 \mathrm{~km}$ below the mouth of the Pecos River, Val Verde County. T. W. Stanton, 1898; W. F. Cummins, 1898(?).

136 - 11853 - Washita Group. Top of mesa about $2.4 \mathrm{~km}$ south of Texon Oil Company Santa Rita well, $22.4 \mathrm{~km}$ west of Big Lake, Reagan County. T. W. Stanton and J. A. Udden, 1923.

137 - 11854 - Upper limestone of the Washita Group. Cut and adjacent ravine on the Kansas City and Orient Railway, $4 \mathrm{~km}$ southeast of Big Lake, Reagan County. T. W. Stanton and J. A. Udden, 1923.

138 - 11883 - 1 Devils River Limestone. About $27.4 \mathrm{~m}$ below top of formation in cuts of the highway on east side of the Pecos River bridge, Comstock Quadrangle. T. W. Stanton, 1923.

139 - 11885 - $1.5 \mathrm{~m}$ of limestone in bed of Middle Fork of Sycamore Creek, $1.2 \mathrm{~km}$ southeast of Havilien Oil Company's Weatherbee Well No. 10, about $33.8 \mathrm{~km}$ east of Del Rio (Del Rio Quadrangle) Kinney County. T. W. Stanton and W. H. Ritchey, 1923.

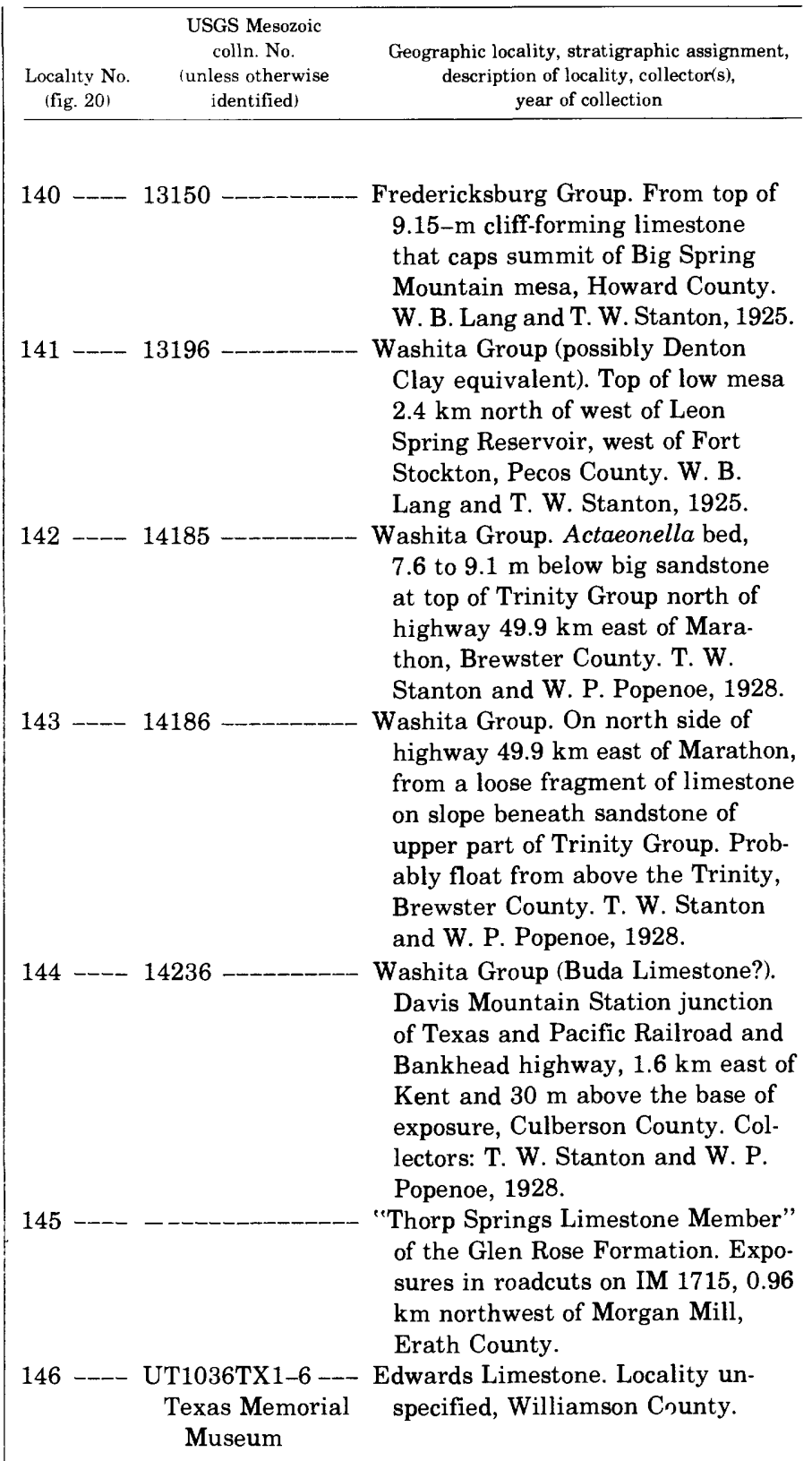

NEW MEXICO, U.S.A.

147 - 1694 - 1 km southwest of Doyles Well, between and in line with the corner monument and the highest peak of Hatchita Mountain (apparently exposures on the south flank of Sierra Rico) in sec. 2, T. 20 S., R. 14 W., Hidalgo County. E. A. Mearns, 1892.

\section{MEXICO}

148

Limestone exposures near Ocuilapa, 2 leagues from Ocozocuautla and 2 leagues from Chapopote, Municipio de Ocozocuautla de Espinsa, State of Chiapas. (Maldonado-Koerdell, 


\begin{tabular}{ccc}
\hline USGS Mesozoic & colln. No. \\
$\begin{array}{c}\text { Locality No. } \\
\text { (fig. 20) }\end{array}$ & $\begin{array}{c}\text { Geographic locality, stratigraphic assignment, } \\
\text { identified) }\end{array}$ & $\begin{array}{c}\text { description of locality, collector(s), } \\
\text { year of collection }\end{array}$ \\
\hline
\end{tabular}

1950, p. 189.) J. T. Singewald, Jr., 1922. Rancho Neuvo Beds (upper part).
Ocuilapa Road at $5 \mathrm{~km}$ northwest
of Ocozocuautla, State of Chiapas.
L. J. Chubb, 1956.

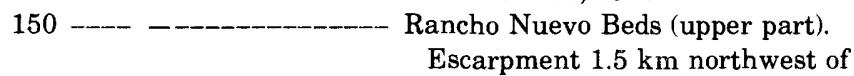
Ocozocuautla, State of Chiapas. L. J. Chubb, 1956.

151 --_ 11467 -_-_ Aquilapa, north of Ocozocuautla, State of Chiapas. Raymond Leibensperger, 1922.

152 -__ 24392 -_____-_ Cardenas Formation. $3.2 \mathrm{~km}$ sout of Rayon, State of San Luis Potosi. Kenneth Segerstrom and Carl Fries, Jr., 1952.

153 -__ 24394 -____ Cardenas Formation. Locality same as that for USGS 24392 (loc. 152); collections from a few meters higher in the section. Kenneth Segerstrom and Carl Fries, Jr., 1952.

154 - 26615 - $100 \mathrm{~m}$ east of point 923 on the second limestone ridge west of Cuautala, Zacatepec district, State of Morelos. Carl Fries, Jr., 1955.

155 -__ 28187 _____ Cardenas Formation. Calcareous shale $28.8 \mathrm{~m}$ thick and $502.5 \mathrm{~m}$ below the top of Bruce Wade's measured section (unit 67 of Imlay; 1944 , p. 1137), east and southeast of Cardenas, State of San

Luis Potosi. Bruce Wade, 1923.

156 -_ 28218 -___ Cardenas Formation. Locality same as that for 28187 , but from unit 69 of Imlay's (1944, p. 1137) portrayal of Wade's Cañon Canada section, a 5.5-m-thick unit of shale and limestone $482 \mathrm{~m}$ below top of section. Bruce Wade, 1923.

157 _-_ 28216 -____ Cardenas Formation. Locality same as that for 28187 , but from unit 80 of Imlay's (1944, p. 1137) portrayal of Wade's Cañon Canada section, a 60-m-thick unit of brown calcareous sandstone and shale $342.7 \mathrm{~m}$ below top of section. Bruce Wade, 1923.

158 -__ 28219 -_____ Cardenas Formation. Locality same as that for 28187 , but from uni 98 of Imlay's (1944, p. 1137) portrayal of Wade's Cañon Canada section, an 8.8-m-thick red and gray shale unit, $60 \mathrm{~m}$ below the top of the section. Bruce Wade, 1923.

159 -_- 28217 - Cardenas Formation. About $2 \mathrm{~km}$ west of Lima and southwest of Valles, State of San Luis Potosi. Bruce Wade, 1923.

\begin{tabular}{|c|c|c|}
\hline $\begin{array}{l}\text { Locality No. } \\
\text { (fig. 20) }\end{array}$ & $\begin{array}{l}\text { USGS Mesozoic } \\
\text { colln. No. } \\
\text { (unless otherwise } \\
\text { identified) }\end{array}$ & $\begin{array}{c}\text { Geographic locality, stratigraphic assignment, } \\
\text { description of locality, collector(s), } \\
\text { year of collection }\end{array}$ \\
\hline & & GUATEMALA \\
\hline \multirow[t]{3}{*}{$160---$} & $28327-$ & $\begin{array}{l}\text { Albian Limestone. Gravity station } \\
\text { (Sohio Company) No. } 972.2 \mathrm{~km} \\
\text { east of Sojio, Robert H. Ray Geo- } \\
\text { physical Survey, about } 12 \mathrm{~km} \\
\text { south of La Libertad, Peten. Bar- } \\
\text { num Brown, } 1948 \text { and } 1950 .\end{array}$ \\
\hline & & CALIFORNIA, U.S.A. \\
\hline & & [Collectors and date not recorded] \\
\hline $161-$ & $\begin{array}{l}\text { CAS. 27831, - } \\
28103\end{array}$ & $\begin{array}{l}\text { Stinking Canyon, } 2.4 \mathrm{~km} \text { north of } \\
\text { Fraziers Corners, Shasta County. }\end{array}$ \\
\hline 162 & $\begin{array}{l}\text { CAS. 10664- --- } \\
\quad 10666,27831\end{array}$ & $\begin{array}{l}4.8 \mathrm{~km} \text { north of Bellavista, } 3.2 \mathrm{~km} \\
\text { above the Cawkins home on Little } \\
\text { Cow Creek, Shasta County. }\end{array}$ \\
\hline $163--$ & CAS. 444, & $\begin{array}{l}\text { Rocky Gulch near Hornbrook, Sis- } \\
\text { kiyou County. }\end{array}$ \\
\hline $164-$ & CAS. 33721--- & $\begin{array}{l}\text { South Fork Cow Creek, Shasta } \\
\text { County. }\end{array}$ \\
\hline 16 & $\mathrm{CA}$ & Woodman Creek, Shasta Count \\
\hline $166---$ & $\mathrm{CA}$ & $\begin{array}{l}\text { Near Klamath River } 2.4 \mathrm{~km} \text { south } \\
\text { of Hornbrook, Siskiyou County. }\end{array}$ \\
\hline $167 \ldots$ & CAS. 733 & $\begin{array}{l}8 \mathrm{~km} \text { southwest of Corona, Orange } \\
\text { County. }\end{array}$ \\
\hline $168---$ & CAS. 1293-- & Bella Vista District, Shasta County. \\
\hline & & ALASKA, U.S.A. \\
\hline $169--$ & 2672 & $\begin{array}{l}\text { Right bank of the Yukon River, } 8 \mathrm{~km} \\
\text { above Nohatatietin, Yukon. A. J. } \\
\text { Collier, } 1902 \text {. }\end{array}$ \\
\hline $170--$ & 2 & $\begin{array}{l}\text { From above Nulato and below Pick- } \\
\text { art's coal mine, on the north or } \\
\text { right bank of the Yukon River, } \\
\text { Koyukuk River region. F. C. } \\
\text { Schrader, } 1899 \text {. }\end{array}$ \\
\hline
\end{tabular}

\section{SYSTEMATIC PALEONTOLOGY}

In the following descriptions, morphologic terminology generally conforms with that used in "Treatise on Invertebrate Paleontology" (Cox, 1960). In the sections on measurements, the following abbreviations are used:

$\mathrm{H}$, total height of shell, measured in millimeters parallel to axis of coiling.

$M D$, maximum diameter of shell, measured in millimeters normal to axis of coiling.

PA, pleural angle, measured in degrees.

$\mathrm{HB}$, height of body whorl, measured parallel to axis of coiling.

Under the section on types, the following abbreviations are used:

USNM, U.S. National Museum

USGS, U.S. Geological Survey Mesozoic Locality 
UT, University of Texas

CAS, California Academy of Sciences

The numbers listed for areas cited in sections on occurrence refer to detailed locality information provided in the locality register (p. 35).

Superfamily ACTEONIDAE

Family ACTAEONELLIDAE

Genus TROCHACTAEON Meek, 1863

Type by original designation, Actaeonella renauxiana d'Orbigny

Diagnosis.-Elongate ovate to subcylindrical, moderately thick walled shells. Breadth of body whorl greatest above midheight. Spire gently concave to convex in profile and less than half total shell height. Aperture elongate, broadening anteriorly, posteriorly sinused; inner lip callused, columella normally bearing three prominent folds but rarely two or four; outer lip smooth or bearing one low ridgelike plait.

Discussion.-A detailed review of the older views on the genus has been given by Kollmann (1967). Although many subdivisions of the genus have been made by Meek (1863) and Hacobjan (1963, 1972), we recognize only four valid subgenera, as discussed below: Trochactaeon (Trochactaeon) Meek, 1863; T. (Neocylindrites) Sayne, 1932; T. (Sevanella) Hacobjan, 1972; T. (Mexicotrochactaeon) Hacobjan, 1972.

Subgenus Trochactaeon Meek, 1863

Type by original designation Actaeonella renauxiana d'Orbigny.

Diagnosis.-Proportional breadth of shell high for genus (height/width ratio $1.4: 1$ to $2: 1$ ) and thick walled. Spire height variable, whorl sides well rounded. Growth lines arcuate. Aperture expands anteriorly; parietal lip smooth; columella with three or rarely four plaits, one as a high palatal ridge.

Discussion.-Subjective synonyms include: Spiractaeon Meek, 1863; Mesotrochactaeon Hacobjan, 1972; Neotrochactaeon Hacobjan, 1972; Purpuractaeon Hacobjan, 1963.

In 1863, Meek erected the genus Spiractaeon for high-spired species that we here assign to Trochactaeon (Trochactaeon). Recognition of Spiractaeon is untenable because the proportional height of spire within the individual species Meek assigned is so variable that it encompasses the full spectrum of form shown within Trochactaeon (Trochactaeon) and Spiractaeon.

Neotrochactaeon was proposed by Hacobjan (1972) to accommodate species whose shells have an especially low spire and strongly inflated whorls. The included species show a considerable variety of form, so far as shell obesity and spire height are concerned. In this sense, many species would fall within the definition of Spiractaeon Meek, here considered a synonym of $T$. (Trochactaeon). Other species, such as Actaeonella (Trochactaeon) burckhardti Böse and $A$. (T.) quadriplicatus Böse bear a ridge on the inner surface of the outer lip and are more properly considered members of $T$. (Mexicotrochactaeon). The taxonomically crosscutting nature of Neotrochactaeon makes it of little value, and it is thus considered unusable.

We also consider the genus Mesotrochactaeon Hacobjan, 1972, as a synonym of $T$. (Trochactaeon). It was established for a group of Trochactaeon species with "elongate-oval to semicylindrical, narrow shells with a high or medium spire and elongate last whorl; lateral walls of whorls weakly convex; aperture significantly widened anteriorly, with the appearance of the ridgelike fold of the outer lip; three plaits on columella" (original diagnosis by Hacobjan, 1972, p. 8; translated from the Russian). In this group, Hacobjan included some nine species from the Cenomanian(?) and Turonian in an area ranging from California through North Africa and southern Europe to the Transcaucasus. He separated these species from Trochactaeon "by the semicylindrical rather than conoid outlines of the whorls and of the shell and by presence of a more developed spire" (original diagnosis by Hacobjan, 1972, p. 8; translated from the Russian). The group stands in an intermediate position between $T$. (Neocylindrites) and Trochactaeon s.s. relative to overall shell form. However, the whorls are broad in their lower part, as in $T$. (Trochactaeon), and because this characteristic is probably of more importance than the overall shell form, we prefer to leave this group within $T$. (Trochacteon).

Hacobjan (1972) established the new genus Purpuractaeon for five species of Trochactaeon that have nodes on the exterior of the shell. Their relationship will be discussed under Trochactaeon (Trochactaeon) woodsi Rennie (1930). The diagnosis of Purpuractaeon is as follows: "Shell large conical to oval, spire relatively high; whorls convex, sutures with a ramp; sculpture consists of spiral nodes at the upper margin of the whorls; aperture narrow posteriorly, anteriorly widening like a chamber; outer lip with a rounded ridgelike plait internally; strong columella with three plaits." (Original diagnosis by Hacobjan, 1972, p. 12; translated from the Russian.)

As diagnosed, Purpuractaeon differs from Trochactaeon (Trochactaeon) only by the presence of nodes at the shoulder. The nodes are formed by a periodic extension of the mantle. The function of such nodes is presently unknown, even in many living node-bearing gastropods. The presence or absence of spines or nodes, however, does not seem to reflect a major change in the organization of soft parts. Accordingly, we consider 
these species as belonging to $T$. (Trochactaeon) and place Purpuractaeon in synonomy.

\section{Subgenus Neocylindrites Sayn, 1932}

(Synonym: Paleotrochactaeon Hacobjan, 1972)

Type by original designation Trochactaeon (Neocylindrites) barremicus Sayn, 1932.

Diagnosis. - "Trochactaeon with cylindrical or nearly cylindrical sides; whorls enclose the preceding ones to more than two-thirds of their height; aperture in the lower part only slightly wider than above; 2 to 3 columellar plaits." (Original diagnosis by Kollmann, 1967, p. 215; translated from the German.)

Discussion. $-T$. (Neocylindrites) differs from T. (Trochactaeon) by its high cylindrical or subcylindrical whorls, each of which strongly overlaps the preceding one. The whorls are narrow, and the shell is therefore proportionally more slender.

Hacobjan (1972) proposed the genus Palaeotrochactaeon on the basis of species that originally were encompassed within the concept of $T$. (Neocylindrites). He included the following species: $T$. absalonis Fraas, T. angustatus Ptselintsev, T. briarti Geinitz, T. cordieroi Choffat, $T$. crisminensis Choffat (type species), and $T$. cylindraceus Stoliczka.

The diagnosis of Palaeotrochactaeon Hacobjan (1972, p. 6) is as follows: "Shell small, conical semicylindrical to cylindrical, with short spire and high last whorl, regularly tapering at base; surface of whorls flattened and smooth; aperture elongate and narrow, with straight thick walls, columella with three plaits." This translation of Hacobjan's diagnosis from the Russian virtually parallels that of $T$. (Neocylindrites).

Sayne's (1932) original description of the type species of $T$. (Neocylindrites) indicates a wide range of interspecific morphologic variability. Choffat (1901-1902) figured five specimens of Trochactaeon crisminensis, the type species of Palaeotrochactaeon Hacobjan, that show a degree of variability similar to that of $T$. (N.) barremicus in whorl convexity, midwhorl depression, and variable height of the spire. In both $T$. (Neocylindrites) and Palaeotrochactaeon the aperture is high and narrow. In view of the range of character variability shown by the two proposed taxa, plus the overall similarity of the two, we see no reason to distinguish Palaeotrochactaeon from $T$. (Neocylindrites).

\section{Subgenus Sevanella Hacobjan, 1972}

Type by original designation Sevanella laticostata Hacobjan, 1972.

Diagnosis.-"Shell of medium to large size ovi-conical, with high spire. Whorls overall convex but irregular in profile because of presence of a broad and deep spiral depression in medial part; sculpture consists of strong, transverse, foldlike ribs or of spiral rows of nodes that occur both on upper and lower portions of whorls; aperture short, narrow, and about equal width throughout its length; plait of outer lip and parietal callus rather strong, thus giving aperture a somewhat sinuate character; apertural walls much thickened. Columella massive and bears three plaits." (Original diagnosis of Hacobjan, 1972, p. 12; translated from the Russian.)

Trochactaeon (Sevanella) differs from Trochactaeon (Trochactaeon) by possessing a strong median depression of the body whorl and in having strong rounded transverse ribs above and below this depression. The palatal ridge is exceptionally strong. According to Hacobjan's (1972, pl. 2) figures, the shells also bear a small parietal ridge which was not mentioned in the diagnosis.

The subgenus is known only from the type species from the upper Coniacian of Armenia (fig. 8).

Subgenus Mexicotrochactaeon Hacobjan, 1972

Type by original designation Actaeonella (Trochactaeon) acutissima Böse = Actaeonella (Trochactaeon) coniformis Böse, 1906.

Diagnosis. -"Shell narrow, biconical, or with a conical turriculate spire; last whorl low; upper part of whorls weakly convex, but narrowing strongly below toward point, becoming conical in outline anteriorly; aperture narrow, siltlike, short and very slightly broadened anteriorly; ridgelike plait on the outer lip weakly developed; columella with 3 plaits." Original diagnosis by Hacobjan, 1972, p. 13; translated from the Russian.)

Discussion.-Böse (1906) described 10 species of Trochactaeon from the same stratigraphic horizon within the Cardenas, Mexico section. These are: Actaeonella (T.) coniformis; A. (T.) acutissima; A. (T.) occidentalis; A. (T.) gigantea, A. (T.) inconstans; A. (T.) irregularis; A. (T.) brevis; A. (T.) planilateralis; A. (T.) potosiana; A. (T.) variabilis. With the exception of Actaeonella (Trochactaeon) gigantea Sowerby, Myers (1968), in his study of the Cardenas section, considers them all as belonging to the same species, and, following article 24(a) of the International Code of Zoological Nomenclature, he chose the name Trochactaeon coniformis for Böse's simultaneously published names. Hacobjan (1972) established the new genus Mexicotrochactaeon and selected Actaeonella (Trochactaeon) acutissima Böse, 1906, as type species. Myers (1968), the first reviser of Böse's species, considered T. acutissima as a junior synonym of Trochactaeon coniformis.

After examination of a large suite of specimens of the type species, we find that $T$. (Mexicotrochactaeon) can only consistently be characterized by the presence of a parietal fold or ridge. Minute differences in the whorl shape and especially in the palatal ridge, which Hacob- 
jan used as criteria for separating $T$. (Mexicotrochactaeon) and the other subgenera of Trochactaeon, should not be used for establishing new genera or subgenera within this group.

Trochactaeon (Trochactaeon) woodsi (Rennie)

Plate 4, figures 6-8, 12; plate 5, figures 1-5; plate 6, figures 1, 2, 4, 5; plate 7 , figures 4,5

1906. Actaeonella (Trochactaeon) sp. Woods, South African Museum Annals, v. 4, p. 328, pl. 41, fig. 1.

1930 Actaeonella (Trochactaeon) woodsi Rennie, South African Museum Annals, v. 28, p. 232, pl. 28, figs. 17-21.

Diagnosis.-A Trochactaeon with 11 to 12 strong nodes at whorl shoulder.

Original description.- "Shell elongately oval, stout. Spire of about 6 whorls, moderately convex, the shape obscured by a row of very large, stout tubercles; spiral angle of $70^{\circ}-80^{\circ}$. Last whorl longer than the spire, cylindrical in form, tapering gradually towards the anterior base tapering more rapidly; posterior part with a sloping ledge adjacent to the well marked but shallow suture, the upper part of the whorl ornamented with 10 to 12 very stout tubercles. Surface smooth, except for faint growth lines on the last whorl, slightly convex toward the aperture. Columella short, with three strong folds, of which the posterior is much stronger than the other two, and the anterior is weakest. Outer lip thin." (Rennie, 1930, p. 232.)

Additional description.-Shells large to very large; maximum diameter 53-73 percent of total height. Spire variable in height, whorls convex, all before last one having 8-10 strong conical tubercles; growth lines strongly opisthoclinely sinused over tubercles, and curving opisthoclinely at broad collarlike substural ramp. Body whorl 68-89 percent of total height, with 11 to 12 tubercles; regularly tapering below tubercles towards base in early stages, but convex sided or occasionally having midwhorl depression in later growth stages. Aperture broad, with deep posterior sinus at suture; columellar lip only slightly expanded and reflected at edge, which is formed by uppermost plait. Plaits decreasing in strength anteriorly. Parietal lip thin, decreasing slightly in thickness towards posterior part of aperture. Plaits resorbed anteriorly on all whorls except for last. Parietal wall of penultimate whorl resorbed adjacent to columella and forming a scar divided by a small ridge; on earlier whorls, this zone is completely resorbed and smooth.

Measurements (fig. 26).-The full range of size among some 27 specimens is: $\mathrm{H}, 78-166 \mathrm{~mm}$; MD, 52-102 mm; $\mathrm{HB}, 61-126 \mathrm{~mm}$; PA, $60^{\circ}-110^{\circ}$.

Discussion.-The following Late Cretaceous species of $T$. (Trochactaeon) that have tubercles or nodes have been described:

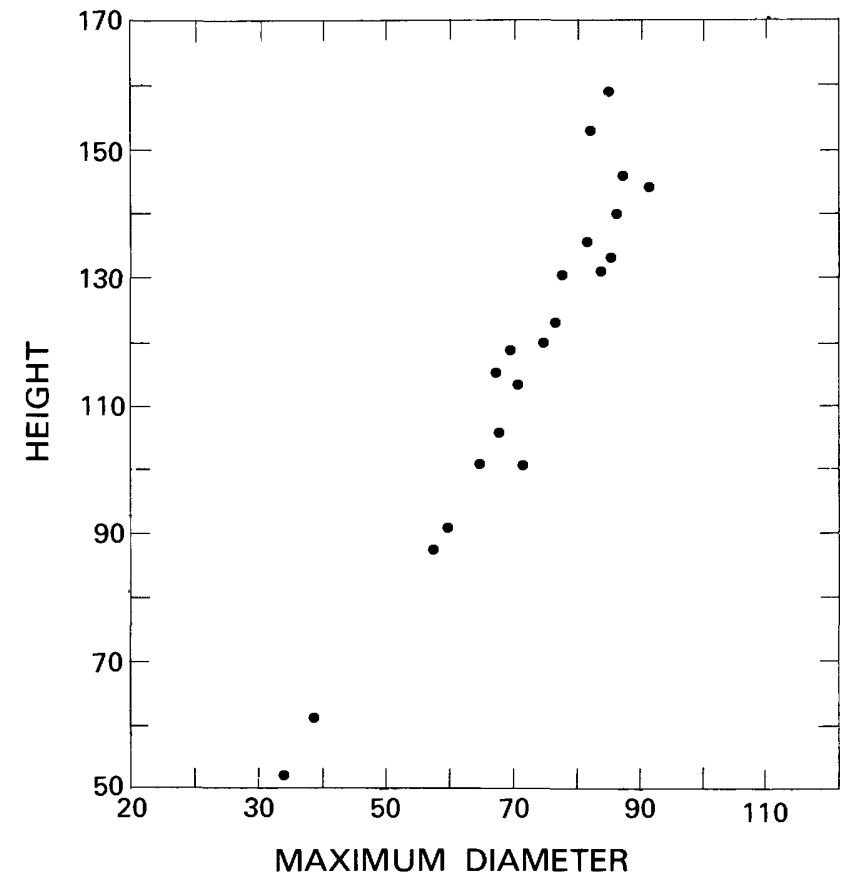

FIGURE 26.-Scatter diagram comparing height with width among selected specimens of Trochactaeon (Trochactaeon) woodsi (Rennie).

T. (Trochactaeon) woodsi (Rennie) from Pondoland, South Africa (Santonian-Campanian), and Puerto Rico (upper Campanian-lower Maastrichtian).

$T$. (Trochactaeon) beyrichi (Drescher) from the Upper Quader of Giersdorf, the Papanberg near Blankenburg, and the sandstone of Kieslingswalde near Habelschwerdt (Bystrzyca Kiedzkaq), Silesian Poland (Coniacian).

Purpuractaeon conicus Hacobjan, 1963, from the Devi River, Armenian SSR. Because it is considered here as a Trochactaeon, the name becomes a junior secondary homonym of Trochactaeon conicus (Muenster) (upper Coniacian), but we refrain from substituting a new name without being able to study the type material.

T. (Trochactaeon) pcelinsevi (Hacobjan, 1963), also described as a Purpuractaeon from the Devi River, Armenian SSR. (Upper Coniacian).

Cassidaria cretacea Mueller, 1851, assigned by Holzapfel (1888) to Actaeonella, possesses nodes and a spire suggestive of this genus. The species was described from steinkerns; therefore, doubts exist about its true affinities.

The specimens that Rennie figured are small, and the heights of the spires vary considerably. The specimens show a depression on the side of the body whorl and have 10 to 12 nodes that lie in the same position on the whorl as do nodes on the specimens from Puerto Rico upon which the additional description was based. 
Although our specimens are generally much larger and broader than the African specimens, several have the same proportions. Sections (pl. 5, fig. 5) show that the earlier growth stages consisting of 4 to 5 whorls are usually not as much inflated as the later stages. The number and shape of tubercles are also the same in the specimens from Puerto Rico and those from Pondoland. In view of the lack of any significant differences between the specimens from the two areas, we consider them as belonging to one species.

$T$. (Trochactaeon) beyrichi (Drescher) has the same proportions as $T$. (Trochactaeon) woodsi but possesses only 8 very broad and rounded nodes per whorl. As in the very large specimens from Puerto Rico, the nodes are flatter on the body whorl.

In $T$. (Trochactaeon) pcelinsevi (Hacobjan), the nodes are large and rounded, as in Trochactaeon beyrichi, but on the basis of only the single figured specimen, the whorls are more inflated than those of $T$. (Trochactaeon) beyrichi. In total aspect, however, T. (Trochactaeon) pcelinsevi is rather similar to large specimens of T. (Trochactaeon) woodsi.

The species is common in certain areas in southwestern Puerto Rico. At locality 39 (USGS 30512) specimens occur as a virtually paucispecific bed of individuals. The specimen figured on pl. 5, fig. 1, is silicified and shows especially well the subspinose flangelike periodic extension of the nodes that is not seen on the larger worn specimens. This specimen also shows delicate subsutural features that are obliterated on other specimens because of poor preservation. Immediately below the suture is a channel with a concave base about $1.2 \mathrm{~mm}$ broad margined by a raised sharp-edged paper-thin rim. The growth lines are crescently sinused within this channel, which marks the position of the posterior (exhalent) siphon. On the bordering rim, the lines are strongly prosoclinely flexed, a direction that carries onto the steep slope above the shoulder, where the prosocline inclination is at an angle of about $105^{\circ}$ to the axis of coiling. The growth lines bend down to only slightly prosocline over the shoulder, save where the shoulder nodes are produced into strongly opisthoclinely directed raised flanges (see pl. 5, fig. 1).

Occurrence.-Puerto Rico: Barranquitas Quadrangle, Pozas Formation, Botijas Limestone Member, at localities 8 and 9 and Reves Member, at localities 5, 6, and 7; San German Quadrangle, Cotui Limestone, at localities 39, 40, 41, 44, 45, and 46, and Sabana Grande Formation at locality 43. South Africa: Natal (Pondoland), Umzamba Formation.

Age.-The type occurrence in the Umzamba Formation on the coast of Natal (Pondoland), South Africa, has been considered by Kennedy and Klinger (1975) to range in age from late Coniacian to early Campanian.
Subsequently, Kennedy (1979) suggested a Santonian to Campanian Age for the formation. The exact position within this range from which $T$. (T.) woodsi was collected is not known. In Puerto Rico, the species is associated with molluscan faunas considered of possible latest Campanian Age and ranging into the earliest Maaestrichtian.

Types:-Holotype, Transvaal Museum; hypotypes, Puerto Rico, USNM 306006, 306007, 306011-30618.

Trochactaeon (Trochactaeon) cf. T. (Trochactaeon) woodsi (Rennie) Plate 4, figures 9-11; plate 6, figure 3; plate 7, figures 1-3.

Description.-Shells globular, spire proportionally low; about seven whorls; body whorl about 80 percent of total height; whorl sides convex, maximum diameter in upper third. Body bearing 11 broadly round-topped, flattened nodes on subsutural shoulder; growth lines weakly sinused over subsutural area, gently prosocline over upper third of body below shoulder and then gently prosocline over basal slope. Aperture proportionally broad, columella thick, columellar lip only slightly expanded and bearing three plaits; parietal lip of equal thickness throughout its full length; palatal ridge broad and strong.

Measurements.-The most complete specimen, which lacks about $5 \mathrm{~mm}$ of its apical tip, measures $75 \mathrm{~mm}$ in length, $60 \mathrm{~mm}$ in maximum diameter, and $63.7 \mathrm{~mm}$ in body-whorl length.

Discussion.-All the available specimens of this form are somewhat deformed and eroded or worn. They undoubtedly do, however, represent a noded Trochactaeon with undetermined affinities to $T$. (Trochactaeon) woodsi (Rennie). Compared with the Puerto Rican specimens previously assigned to that species, the nodes of the better preserved specimens are more rounded but less prominent and thus may represent a new form.

Occurrence.-Puerto Rico: Orocovis Quadrangle, Pozas Formation, Rio Bauta Member, at localities 25, 26 , and 27.

Age.-Lower Campanian.

Types.-Hypotypes, USNM 306008-30610, 306019, 306020.

Trochactaeon (Trochactaeon) frazierensis (Anderson)

Plate 8 , figures $1-5$

1958. Acteonella frazierensis Anderson, Geol. Soc. America mem. 71, p. 161, pl. 29, figs. 7, 7a.

1958. Acteonella rustica Anderson, Geol. Soc. America mem. 71, p. 161 , pl. 29 , fig. 5 .

Diagnosis. - Trochactaeon of medium size with a proportionally high spire. Whorls with broad subsutural ramp, slightly rounded in upper part of whorl and subcylindrical below. Body whorl inflated medially. Columella short. 
Description. - "The mature shell is of moderate size, biconical in general aspect, spire of moderate height; body whorl of equal length sloping downward to columella; aperture nearly straight, narrow above, and expanded below; outer lip thin and nearly straight; inner lip converging gradually from outer lip above, expands suddenly below to anterior canal; columella carries three oblique plications, the anterior being reduced in size near anterior end of columella. Shoulders of whorl slightly rounded and tabular above, with a slight collar rising on the preceding whorl." (Anderson, 1958, p. 161).

Additions to Description.-The spire is somewhat convex in profile and proportionally high for the genus. The whorl sides are slightly rounded in their upper posterior portions and primarily cylindrical below. A subsutural ramp is a prominent feature and is nearly horizontal to the shell axis. No collar such as described by Anderson, however, could be observed. On the larger specimens (pl. 8, fig. 5), the body whorl is more convex than on smaller specimens (pl. 8, fig. 1), bears a slight depression, and is 71 to 78 percent as long as the total shell length. The aperture is broad and the columella is much shorter than indicated in Anderson's (1958, pl. 29, figs. $5,7,7$ a) illustrations (compare pl. 8 , figs. 1,4 , and 5 ). The outer margin of the inductura is deviated about $20^{\circ}$ away from the shell axis.

Measurements. -The incomplete holotype (CAS 10664 ) is $43.4 \mathrm{~mm}$ high and has a maximum diameter of $21.5 \mathrm{~mm}$ and a body-whorl length of $27.9 \mathrm{~mm}$. The pleural angle is $48^{\circ}$. Two paratypes measure as follows (in $\mathrm{mm}$ except as shown):

$\begin{array}{cccc}H & M D & H B & P A \\ \mathbf{5 3 . 5} & 28.4 & 38.3 & 50^{\circ} \\ \mathbf{5 2 . 5} & 30.8 & 40.0 & 40^{\circ}\end{array}$

Discussion.-The type specimens of $(T$.) Trochactaeon frazierensis (Anderson) come from lower Turonian beds near Redding in Shasta County, Calif. In the same publication in which Anderson (1958) defined this species, a second species, Actaeonella rustica, was also described from other exposures of lower Turonian rocks within the same area. In the description of $A$. rustica, Anderson $(1958$, p. 161) stated:

Shell similar to Actaeonella frazierensis $\mathrm{n}$. sp., although relatively stouter and more biconic in form, and distinct in most of its other external features. The holotype ${ }^{* * *}$ consists of the body whorl and five spiral whorls including apex, which is slightly reduced by weathering of shell substance***. The body whorl is little impressed near its middle, thus modifying its conical form, and in some examples giving them a slightly barrel shape.

Anderson's figures of both species are rather sketchily hand drawn and in obvious error in several regards. Examination of Anderson's specimens shows, for example, that they are all incomplete and that the total number of whorls cannot be determined save that there are more than the stated five whorls. The most nearly complete specimens possess a body whorl that isw 45 to 60 percent of the total shell height.

Although Anderson (1958) separated his species Actaeonella rustica and A. frazierensis primarily because the latter has more convex sides, a comparison of the photographs of the type specimen on plate 8 , figure 2 with the original hand-drawn figures shows exaggeration in this character. We see no significant difference between the two named species in this regard and synonymize $A$. rustica under $A$. frazerensis by page preference.

Some specimens of T. (Trochactaeon) matensis (Fittipaldi) may have an equally high convex spire, and a subsutural ramp of equal strength as $T$. (Trochactaeon) frazierensis (see Pchelintsev, 1953; Lupu, 1965) but, they differ in always possessing a proportionally long and evenly convex body whorl that lacks any medial constriction or depression. Trochactaeon (Trochactaeon) lamarcki (Sowerby), a common species in Upper Cretaceous deposits of Central Europe and the Middle East, is somewhat similar but possesses a proportionally shorter spire and more convex whorls.

Occurrence.-California (Siskiyou and Shasta Counties), Hornbrook Formation and Chico Formation, at localities 161 to 165.

Age.-Turonian.

Types.-Holotype (A. frazierensis), CAS 10664; paratype, CAS 10665. Holotype (A. rustica), CAS 10666.

Trochactaeon (Trochactaeon) packardi (Anderson)

Plate 8, figures $15-17$

1902. Actaeonella oviformis Gabb. Anderson, California Acad. Sci. Proc., 3d ser., v. 2, p. 28, 34.

1916. Actaeonella oviformis Gabb. Packard, California Univ., Dept. Geol. Sci. Bull., v. 9, no. 2, p. 144, 147.

1922. Actaeonella oviformis Gabb. Packard, California Univ. Dept. Geol. Sci. Bull., v. 13, no. 10, p. 458, pl. 36, fig. 4 .

1954. Acteonella oviformis Gabb. Popenoe, California Div. Mines Bull. 170, table 1, fig. 3, no. 2 .

1958. Acteonella oviformis Gabb. Anderson, Geol. Soc. America Mem. 71 , p. 160 , pl. 29 , fig. 6 .

1958. Actaeonella packardi Anderson. Geol. Soc. America Mem. 71, p. 160 , pl. 29 , fig. $4,4 a, 4 b$

Diagnosis.-Shell of small to medium size, broadly subcylindrical. Spire low to immersed. Subsutural ramp broad and horizontal. Palatal swelling weak.

Description.-Shell of small to medium size, elongate oviform, maximum diameter 47 to 58 percent of total height. Spire very short to immersed. Shell of 6 to 7 whorls that have a broad subsutural ramp horizontal to shell axis. Height of body whorl 84 to 99 percent of total height. Body slightly convex, often with a weak inflation above midline. Sides of columella form a very 
acute angle to shell axis. Columellar lip reflected and thick outside aperture; posteriormost plait delimits upper edge of columella and is only plait visible outside aperture. Within shell, posterior plait strongest, medial one weakest; columella below plaits short; parietal lip equally thin throughout its length; palatal swelling weak and only present in second half of penultimate whorl and in first part of body whorl; columella resorbed in earliest parts of last whorl and remainder of shell.

Measurements (in mm except as shown) (see fig. 27).-

\begin{tabular}{lllll} 
& \multicolumn{1}{c}{$H$} & \multicolumn{1}{c}{$M D$} & \multicolumn{1}{c}{$H B$} & $P A$ \\
Holotype & $\begin{array}{l}\text { 66.2 (estimated 68) } \\
\text { Paratypes }\end{array}$ & 30.0 & 59.5 & $110^{\circ}$ \\
& $\begin{array}{l}\text { 21.7 to } 75 \\
\text { (estimated 80) }\end{array}$ & 11.2 to 41.7 & 21.7 to 73.4 &
\end{tabular}

Discussion.-The specimens that Anderson (1958) assigned to Acteonella oviformis Gabb are silicified like

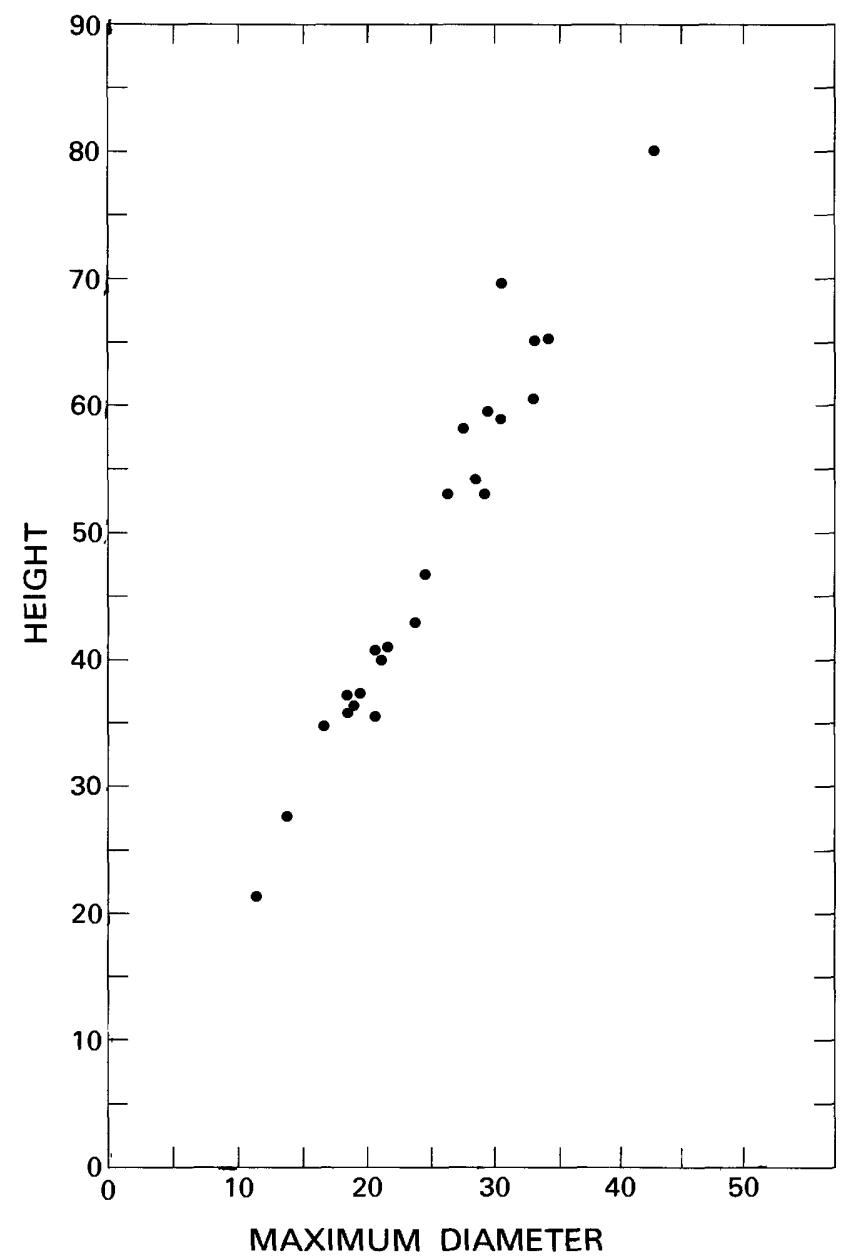

FIGURE 27.-Scatter diagram comparing height with width among selected specimens of Trochactaeon (Trochactaeon) packardi (Anderson). the sandstone in which they have been found, but imperfect replacement results in all isolated specimens being more or less incomplete. The type of Actaeonella oviformis Gabb is similarly preserved, the outer whorls being incomplete. Gabb's specimens, however, have straight growth lines and are referable to Actaeonella, whereas the specimens described by Anderson (1902, 1958) under the name oviformis belong to the genus Trochactaeon. This is also true of Anderson's Acteonella packardi. Anderson's holotype of A. packardi, which is the same specimen Packard (1922) figured and assigned to Actaeonella oviformis Gabb, is about twice as high as most of the silicified specimens of his Acteonella oviformis. Among the specimens from localities CAS 252 and 733, the size range easily encompasses both Acteonella oviformis and A. packardi of Anderson. As there are no significant differences in the height-width ratios and in general morphology, Anderson's A. oviformis is considered to be a synonym of Trochactaeon (Trochactaeon) packardi.

Trochactaeon (Trochactaeon) matensis (Fittipaldi) and T. (Trochactaeon) cylindraceus Stoliczka are morphologically closely similar to $T$. (Trochactaeon) packardi. T. (Trochactaeon) matensis was described by Fittipaldi from the Turonian of Campobasso, Italy. It also occurs in the Cenomanian and lower Turonian of the TransCaucasus area, where it includes $T$. (Trochactaeon) cylindricus Pchelintsev (1928) and T. (Trochactaeon) pseudocylindraceus Pchelintsev (1953). T. (Trochactaeon) matensis, recorded from the upper Cenomanian of Cherghes, Romania, by Lupu (1965) has a more convex body whorl and a spire proportionally higher and more convex in profile than that of $T$. (Trochactaeon) packardi (Anderson). Longitudinal sections show a much stronger palatal swelling than in $T$. (Trochactaeon) packardi, which narrows the interior of the whorls considerably.

The body whorl of $T$. (Trochactaeon) cylindraceus Stoliczka from the Arialoor Group of southern India is proportionally shorter than that of $T$. (Trochactaeon) packardi and T. (Trochactaeon) matensis. Stoliczka (1868) pointed out the obtuse attenuation of the lower part of the body whorl, which bends strongly towards the axis from the upper more cylindrical part. The internal molds of a Trochactaeon Darteville and Brebion (1956) described as Actaeonella (Trochactaeon) cylindracea Stoliczka are too poorly preserved to allow any assignment to a known species of Trochactaeon.

Occurrence.-California: Siskiyou County, at localities 163 and 166; Shasta County, at localities 161, 162, and 168; Orange County (Baker Canyon Conglomerate Member, Ladd Formation), at locality 167.

Age.-Turonian.

Types.-Holotype, CAS 10663; hypotype CAS 733. 
Trochactaeon (Neocylindrites) cumminsi Stanton

Plate 4, figures 1-4; plate 9, figures 9-19

1947. Trochactaeon cumminsi Stanton. U.S. Geol. Survey Prof. Paper 211, p. 111, pl. 63, figs. 3-6, 13 .

1947. Trochactaeon parvus Stanton. U.S. Geol. Survey Prof. Paper 211, p. 112, pl. 63, figs. 1, 2.

1955. Actaeonella parvus (Stanton). Allison, Jour. Paleontology, v. 29, p. 429, pl. 44, fig. 5 .

Diagnosis.-Shell small to medium size, subcylindrical and high. Whorls moderately convex, with a very broad and strongly inclined subsutural ramp. One to two smaller folds occur below main palatal ridge.

Description. - "Shell of medium size, slender, subfusiform, consisting of about 8 whorls, of which the last constitutes two-thirds to three-fourths of the entire length; spire variable, in some specimens mammillated at the summit, the apical angle commonly about $65^{\circ}$ but ranging from $60^{\circ}$ to nearly $80^{\circ}$; suture slightly impressed; whorls of the spire gently convex, but some whorls bear a very slight angulation near the middle, which marks the position of a fine impressed line that forms the anterior border of a broad slit-band or sinus comparable with that in Nerinea; last whorl relatively very large, subcylindrical, with an oblique flattening or shoulder behind occupied by the slit-band, and somewhat produced and contracted in front, the extreme anterior end being obliquely subtruncate; surface marked only by fine growth lines that pass almost straight across the whorl in a broad curve with its convexity directed forward, the curvature increasing suddenly as the lines approach the slit-band, which they cross in a short curve turned in the opposite direction; inner lip thickened in front and bearing 3 strong folds; aperture long and narrow, slightly increasing in width toward the front.

"Internal molds differ greatly from the shell in form, the whorls being prominently shouldered with the maximum breadth behind, and the last whorl showing a well-marked spiral groove or constriction a little in advance of the middle, with a second and occasionally a third groove less distinctly marked in front of it.

"The largest of the types, one of the more slender forms with an apical angle of $60^{\circ}$, has the following measurements: Height $76 \mathrm{~mm}$., height of spire $26 \mathrm{~mm}$., maximum breadth $27 \mathrm{~mm}$., breadth of slitband $5 \mathrm{~mm}$. Corresponding measurements of a stouter specimen with an apical angle of $70^{\circ}$ are $60,15,25$, and $3.8 \mathrm{~mm}$." (Stanton, 1947 , p. 111,112 .)

As we consider Trochactaeon parvus Stanton a synonym of $T$. (Neocylindrites) cumminsi, we quote a passage from Stanton's description of Trochactaeon parvus (1947, p. 112): "Shell small, slender subfusiform, consisting of 5 or 6 whorls, of which the last constitutes nearly two-thirds of the entire length; greatest breadth near the posterior (upper) margin of the last whorl, from which the shell tapers regularly in both directions, the apical angle of the spire about $30^{\circ}$ whereas the sides of the last whorl converge toward the narrow anterior end with an angle of about $20^{\circ}$; exposed portions of whorls of the spire slightly convex, as in Trochactaeon (Neocylindrites) cumminsi Stanton; surface apparently smooth, but the state of preservation is such that the growth lines are not visible, nor is the slit-band on the sloping shoulder of the whorl; aperture long and narrow; inner lip with 3 strong spiral folds near the front."

Measurements (see fig. 28).-The largest of the measured specimens is $74.0 \mathrm{~mm}$, the shortest, $3.3 \mathrm{~mm}$. Small specimens have a maximum diameter as much as 50 percent of total height, whereas larger specimens have a maximum diameter only 33 to 44 percent of total height. The body whorl constitutes 73 to 89 percent of total height.

Discussion.-To the description cited above, we may add that the basal lip is deeply sinuate and evanesces out of the aperture onto the basal part of the body whorl. The inductura is very thin (pl. 9, figs. 16, 19). The columellar plaits are visible for a full one-half volution on the body outside the aperture, but the columellar rim

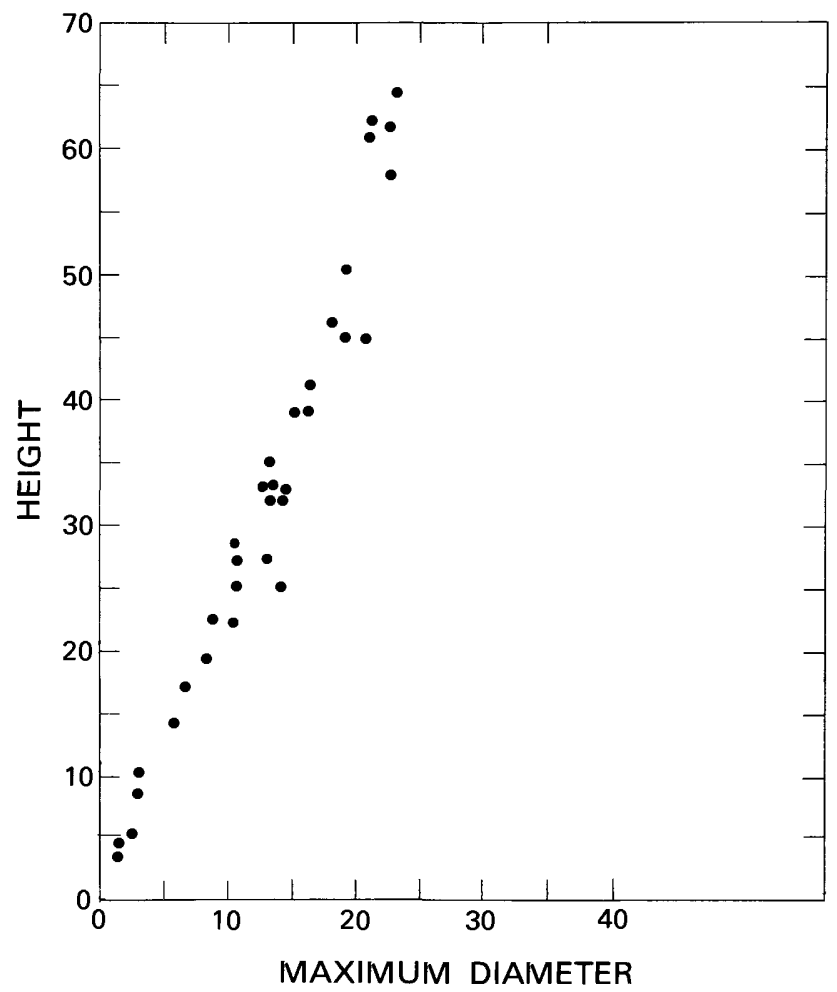

Figure 28.-Scatter diagram comparing height of shell with width among selected specimens of Trochactaeon (Neocylindrites) cumminsi Stanton. 
is poorly defined. Internal molds (pl. 9, figs. 12, 18) show two or three grooves on the palatal area that represent ridges on the shell. The largest of these is present up to the aperture, but the secondary ridges disappear before the aperture is reached. Stanton (1947) pointed out the similarities in shell morphology of $T$. (Neocylindrites) cumminsi and T. (Neocylindrites) parvus. As the main difference between these two species, he cited (p. 112) the "narrow gradually tapering anterior" of T. parvus, as his figures (Stanton, 1947, pl. 63, figs. 1, 2) suggest. Our examination of the figured specimens shows that the fragile outer lip is not preserved so that the impression of a very narrow aperture is an artifact of preservation and is erroneous. With this difference eradicated, we conclude that the two are synonymous, $T$. (Neocylindrites) cumminsi having page preference.

Compared with the European species Trochactaeon (Neocylindrites) briarti Geinitz, 1874, and its possible synonym $T$. (Neocylindrites) crisminensis Choffat, 1901 , the sides of the last whorl are barely convex and taper straight towards the base. In addition, the subsutural ramp is not as prominent as in $T$. (Neocylindrites) cumminsi. Trochactaeon (Neocylindrites) boutillieri Cossmann (1895) together with T. (Neocylindrites) barremicus Sayn (1932) are very small and possess a spire that is very variable in height. In the juvenile stages, few differences exist between these species and Trochactaeon (Neocylindrites) cumminsi, except for a very distinct constriction in the upper part of the last whorl in T. (Neocylindrites) boutillieri. This constriction also persists in the adult specimens of $T$. (Neocylindrites) barremicus var. mumiaeformis Sayn (1932, p. 9, pl. 1, fig. 5).

Occurrence.-Texas: Devils River Limestone, Val Verde County (localities 134, 135, 138); Washita Group, Reagan County (localities 136, 137), Brewster County (localities 142,143), and Pecos County (locality 141); Edwards Limestone, Kerr County, "on Colorado River above the mouth of Barton's Creek near Austin", (Stanton, 1947, p. 112) (locality 132). Baja California: Allisitos Formation.

Age.-Middle to late Albian.

Types.-Lectotype, USNM 306042; syntypes, USNM 306038-306041, 306043, 306044; hypotypes, USNM 306001-306004.

Trochactaeon (Neocylindrites) punctatus (Maldonado-Koerdell), 1950 Plate 4, figure 5; plate 9 , figures $1-6$

1950. Actaeonella cf. A. (Trochactaeon) coniformis Böse. MaldonadoKoerdell, México Escuela Nac. Cienc. Biol. Anales, v. 6, p. 214 , figs. 44,45 .

1950. Actaeonella (Trochactaeon) acutissima punctata MaldonadoKoerdell, México Escuela Nac. Cienc. Biol. Anales, v. 6, p. 215 , figs. $46 a, b$.
1950. Actaeonella cf. A. (Trochactaeon) occidentalis Böse. MaldonadoKoerdell, México Escuela Nac. Cienc. Biol. Anales, v. 6, p. 215 , fig. 47 .

1950. Actaeonella (Trochactaeon) planilateralis Böse. MaldonadoKoerdell, México Escuela Nac. Cienc. Biol. Anales, v. 6, p. 217 , fig. 52 .

Description.-Shells of medium size; maximum diameter 37-39 percent of total height; spire high in small specimens, proportionally low and with concave sides in large ones; whorls with a broad and inclined subsutural ramp terminated distinctly against whorl sides. Body whorl 80 to 89 percent of total height, slightly inflated in upper third; whorl sides tapering first at a low angle and then with slightly increasing steepness towards the narrow base; middle of whorl bearing distinct constriction. Aperture high and narrow. Columella proportionally high, thin, and only slightly expanded, outer rim smooth, bending towards base almost vertically; plaits of about equal strength, distance between upper two wider than between middle and anteriormost one. In large specimens, one additional weak plait occurs between upper two plaits. Parietal lip thin, edge inclined at about $20^{\circ}$ to shell axis. Border of inner lip inclined $20^{\circ}$ to shell axis in parietal region, bending downwards almost vertically at columella, which is little expanded.

Measurements.-The six specimens (USGS 11467) available for measurement show a range of: total height, 21.1-47.5 mm; maximum diameter, 8.0-19.8 mm; pleural angle $50^{\circ}-70^{\circ}$. The lower values are mainly on small specimens.

Discussion.-Maldonado-Koerdell (1950) figured five specimens of actaeonellids from the State of Chiapas in southern Mexico. He assigned all his specimens to taxa previously described by Böse in 1906 from the Maestrichtian of Cardenas, Mexico, but he erected one new subspecies Actaeonella (Trochactaeon) acutissima punctata. Maldonado-Koerdell's material appears to us to belong to a single species differing from specimen to specimen only in the form and height of the spire. These characters are among the most variable in samples of almost any species of the genus. Elsewhere herein, we have accepted all Böse's species and subspecies to which Maldonado-Koerdell assigned his Chiapas specimens to be parts of one variable species Trochactaeon (Mexicotrochactaeon) coniformis Böse. We consider the Chiapas specimens to differ from that species in having proportionally higher and much less convex whorls and a smooth parietal area. These features are characteristic of the subgenus Neocylindrites. We therefore raise Maldonado-Koerdell's subspecific name punctata to species rank and include all the Trochactaeon from Chiapas that he discussed within that species and assign them to Neocylindrites. 
Occurrence.-Mexico; State of Chiapas, at localities $148,151$.

Age.-Maastrichtian. Maldonado-Koerdell (1950, p. 189) assigned the type specimens to the upper Campanian. The listing of associated species, however, suggests a Maastrichtian Age.

Types.-The holotype is in the collections of Petroleos Mexicanos; hypotypes, USNM 306005, 306031-306035.

Trochactaeon (Neocylindrites) nelsoni Sohl and Kollmann, n. sp.

Plate 8, figures 9-14, 18, 19; plate 11, figures 6, 7, 10

Diagnosis.-A T. (Neocylindrites) with broadly convex whorls which are interiorly broad; columella thin, little expanded.

Description.-Shells of small to medium size, subcylindrical, maximum diameter 39 to 54 percent of total height; spire low, whorls with medium broad inclined subsutural ramp. Pleural angle generally $60^{\circ}$ to $70^{\circ}$ in small specimens and $70^{\circ}$ to $90^{\circ}$ on larger forms. Body whorl length 81 to 93 percent of total height, lateral parts forming a distinct angle with ramp; body evenly convex over sides, tapering over lower part more rapidly toward base than in upper part; small specimens tapering evenly towards base throughout. Aperture high, rather broad; columella proportionally long and thin, with three plaits that decrease in size anteriorly; columella only slightly expanded, outer margin smooth; palatal ridge small; resorption of columella starts within last whorl; sides of earlier whorls in lower half nearly completely resorbed, whereas in upper parts, original shell thickness is maintained. Measurements are shown on figure 29.

Discussion.-T. (Neocylindrites) nelsoni shows a great difference in average size at various localities. Low in its range zone at the type locality in the Rio Bauta Member of the Pozas Formation, it is rather small. Upward in its stratigraphic range, average size increases, and it reaches its largest size in the Flor de Alba Limestone Lentil of the Pozas. As seen in figure 29, although size may vary between localities, shell proportions remain remarkably constant save for smaller specimens being less cylindrical and more tapering in outline.

T. (Neocylindrites) nelsoni differs from T. (Neocylindrites) punctatus (Maldonaldo-Koerdell) 1950 by having more cylindrical sides on the body whorl that go straight down from the subsutural ramp without strong inflation. In addition, T. (Neocylindrites) nelsoni lacks a constriction in the middle of the shell, the whorls are broader interiorly and lack the fourth columellar plait typical of large specimens of T. (Neocylindrites) punctatus. Both T. gradatus Kollmann (1967) and T. gosaviensis Kollmann (1967) differ in possessing a more convex body whorl, a horizontal subsutural ramp, and strongly

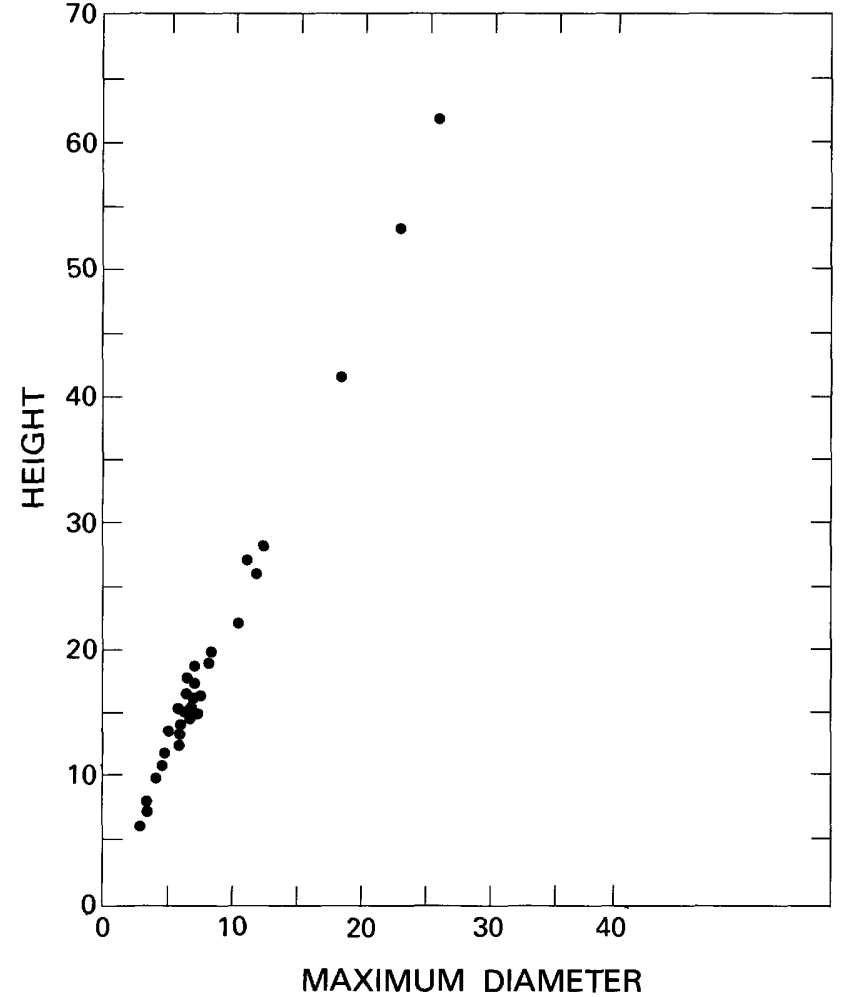

FIGURE 29.-Scatter diagram comparing height with width among selected specimens of Trochactaeon (Neocylindrites) nelsoni Sohl and Kollmann, n. sp.

reflected columella. Trochactaeon (Neocylindrites) cumminsi Stanton (1947) has a very broad and strongly inclined subsutural ramp, narrow and high whorls, a palatal ridge that is very strong, and two additional ridges towards the base. This species is named in honor of Arthur Nelson of the U.S. Geological Survey, for his contributions to the knowledge of the geology of the Florida area, Puerto Rico.

Occurrence.-Puerto Rico: Pozas Formation, Rio Bauta Member (Orocovis Quadrangle), at locality 28; and Flor de Alba Limestone Lentil (Florida Quadrangle), at localities 22, 23, 24; Maravillas Formation (Coamo Quadrangle), at locality 20; Cotui Limestone (San German Quadrangle), at locality 40 (questionable assignment).

Age.-Campanian.

Types.-Holotype, USNM 306028; paratypes, USNM 306024-306027, 306029, 306030, 306064-306066.

\footnotetext{
Trochactaeon (Neocylindrites) sp. A

Plate 8, figures $6,7,8$; plate 11 , fig. 11
}

Description.-Shells of medium size, maximum diameter 30 to 33 percent of total height. Spire very short, with flat sides. Apical angle about $80^{\circ}$. Sutures, due to silification, indistinct. Body whorl high, subcylindri- 
cal, with slightly convex sides. Aperture wider in lower part than in upper. Columella with three large plaits of equal strength broadly reflected at external margin. Deep incision above upper plait. Basal lip thickened and deeply canaliculate, cut off at an angle of $120^{\circ}$ to axis.

Measurements.-Two typical specimens measure as follows (in $\mathrm{mm}$ except as shown):

$\begin{array}{ccc}H & M D & P A \\ 41.5 & 14.0 & 76^{\circ} \\ 35.8 & 10.9 & 80^{\circ}\end{array}$

Discussion.-The known well-preserved specimens of this species are too few to serve as the basis for a new species, but this form seems distinct from previously described species. The maximum diameter of Trochactaeon (Neocylindrites) cumminsi is larger than that of $T$. (Neocylindrites) sp. A, and the sides are more convex in specimens of comparable height. In T. (Neocylindrites) cumminsi, the body whorl diameter is about 40 percent of total height, whereas in T. (Neocylindrites) sp. A it is about 30 percent and the basal lip, which is not very often preserved, seems to be less sinuate and evanescent.

Occurrence.-Puerto Rico: limestone within the El Rayo Formation (Sabana Grande Quadrangle), at locality 36.

Age.-Middle Maastrichtian.

Types.-Hypotypes, USNM 306023, 306084, 306069.

Trochactaeon (Neocylindrites) sp. B

Plate 9, figures 7,8

Description.-Shell of medium size, spire low with slightly convex or flat profile. Whorl sides are flat and taper conically towards base. Columella poorly known, but bearing three plaits.

Discussion.-Only external molds in a silicified limestone are known. The molds are of shells that are less convex than that of Trochactaeon cumminsi Stanton and that have lower whorls and a less strongly developed subsutural ramp. They seem to be closely related to the T. (Neocylindrites) crisminensis-briarti group of Europe.

The specimens described above come from a silicified unit on the southern flank of Sierra Rica in southwestern New Mexico. Zeller (1965), in his study of the nearby Big Hatchet Mountain area, suggested that the silicified limestone of the Sierra Rica was an equivalent of his Mojado Formation. Though Zeller did not report the presence of Trochactaeon in the Big Hatchet Mountains, Actaeonella is present. In addition to the Sierra Rica Trochactaeon, the limestone blocks contain nerineids and bivalves. On the basis of contained fauna, the Mojado Formation is of both Fredricksburg and
Washita age. The nerineid and actaeonellid assemblages come from the upper (Washita) part of the formation. Thus, it seems most likely that the Trochactaeon here discussed is of late Albian Age.

Occurrence.-New Mexico: Mojado Formation, at locality 147.

Age.-Late Albian.

Types.-Hypotypes, USNM 306036, 306037.

Trochactaeon (Mexicotrochactaeon) coniformis (Böse)

Plate 10, figures 1-17; plate 11, figures 1-4

1906. Actaeonella (Trochactaeon) coniformis Böse. Mexico lnst. Geol. Bol. 24, p. 78, pl. 16, figs. 12-21.

1906. Actaeonella (Trochactaeon) acutissima Böse. Mexico lnst. Geol. Bol. 24, p. 79, pl. 16, figs. 4-11.

1906. Actaeonella (Trochactaeon) occidentalis Böse. Mexico Inst. Geol. Bol. 24, p. 81, pl. 17, figs. 2-10.

1906. Actaeonella (Trochactaeon) inconstans Böse. Mexico lnst. Geol. Bol. 24, p. 83, pl. 17, figs. 11-19.

1906. Actaeonella (Trochactaeon) irregularis Böse. Mexico lnst. Geol. Bol. 24, p. 84 , pl. 17, figs. 20-27.

1906. Actaeonella (Trochactaeon) brevis Böse. Mexico lnst. Geol. Bol. 24, p. 85 , pl. 18, figs. 1-7.

1906. Actaeonella (Trochactaeon) planilateralis Böse. Mexico Inst. Geol. Bol. 24, p. 87, pl. 18, figs.8-13.

1906. Actaeonella (Trochactaeon) potosiana Böse. Mexico Inst. Geol. Bol. 24, p. 88, pl. 18, figs. 14-25.

1906. Actaeonella (Trochactaeon) variabilis Böse. Mexico Inst. Geol. Bol. 24, p. 90, pl. 18, figs. 26-34.

1968. Actaeonella coniformis Böse. Myers (part), Mexico Univ. Nac. Autónoma, lnst. Geología, Paleontología Mexicana, no. 24, p. 75, pl. 7, fig. 3, ?5 (not fig. 4).

1972. Mexicotrochactaeon acutissima Böse. Hacobjan, Paleont. Zhur. no. 1, p. 13.

1972. Mexicotrochactaeon inconstans Böse. Hacobjan, Paleont. Zhur, no. 1, p. 13.

1972. Mexicotrochactaeon irregularis Böse. Hacobjan, Paleont. Zhur. no. 1, p. 13.

1972. Mexicotrochactaeon planilateralis Böse. Hacobjan, Paleont. Zhur. no. 1, p. 13.

1972. Mexicotrochactaeon potosianus Böse. Hacobjan, Paleont. Zhur. no. 1, p. 13.

1972. Mexicotrochactaeon variabilis Böse. hacobjan, Paleont. Zhur. no. 1, p. 13.

Not: 1950. Actaeonella cf. A. (Trochactaeon) coniformis Böse. Koerdell, México Escuela Nac. Cienc. Biol. Anales, v. 6 , p. 214 , figs. 44,45 .

Not: 1950. Actaeonella (Trochactaeon) acutissima punctata Böse. Maldonado-Koerdell, México Escuela Cienc. Biol. Anales, v. 6, p. 215, fig. 46a, b.

Not: 1950. Actaeonella cf. A. (Trochactaeon) occidentalis Böse. Maldonado-Koerdell, México Escuela Nac. Cienc. Biol. Anales, v. 6, p. 215, fig. 1 .

Not: 1950. Actaeonella cf. A. (Trochactaeon) inconstans Böse. Maldonado-Koerdell, México Escuela Nac. Cienc. Biol. Anales, v. 6, p. 216, fig. 50 .

Not: 1950. Actaeonella (Trochactaeon) planilateralis Böse. MaldonadoKoerdell, México Escuela Nac. Cienc. Biol. Anales, v. 6 , p. 215 , fig. 47 .

Diagnosis.-Small shells with highly variable spire; whorls with collarlike subsutural ramp. Parietal fold prominent. 
Description.-Shells small, with more or less high, convex spire. Maximum diameter 32 to 52 percent of total height. Shell of six to seven whorls on strongly evolute specimens. Whorl sides of high-spired forms convex, greatest diameter at midheight, slightly compressed posteriorly and convex below. On low-spired forms, only upper depressed part of whorls visible. Body whorl covered with fine growth lines. Subsutural ramp strongly inclined to axis, collarlike, often concave. Body whorl 51 to 91 percent of total height, with depressed shoulder in upper fifth of whorl; below, subconical in outline but somewhat compressed medially. Columellar lip slightly inclined towards axis, uppermost of three plaits most prominent; distance between lowermost plait and basal lip short. Thickening of lower part of parietal lip within aperture continuous with oblique sharp parietal fold on internal whorl surface. In large specimens, this fold is slightly concave below; parietal zone above plait slightly depressed. Resorption of plaits starts at junction of last whorl with penultimate whorl; about $1 / 2$ whorl behind this point, columella and parietal region of penultimate whorl completely smooth. Palatal ridge indistinct because of recrystallization but appears more oblique in penultimate whorl than in body whorl.

Measurements (fig. 30).-The 87 specimens measured ranged in total height from 9.0 to $55.4 \mathrm{~mm}$, and the pleural angle ranged from $19^{\circ}$ to $105^{\circ}$

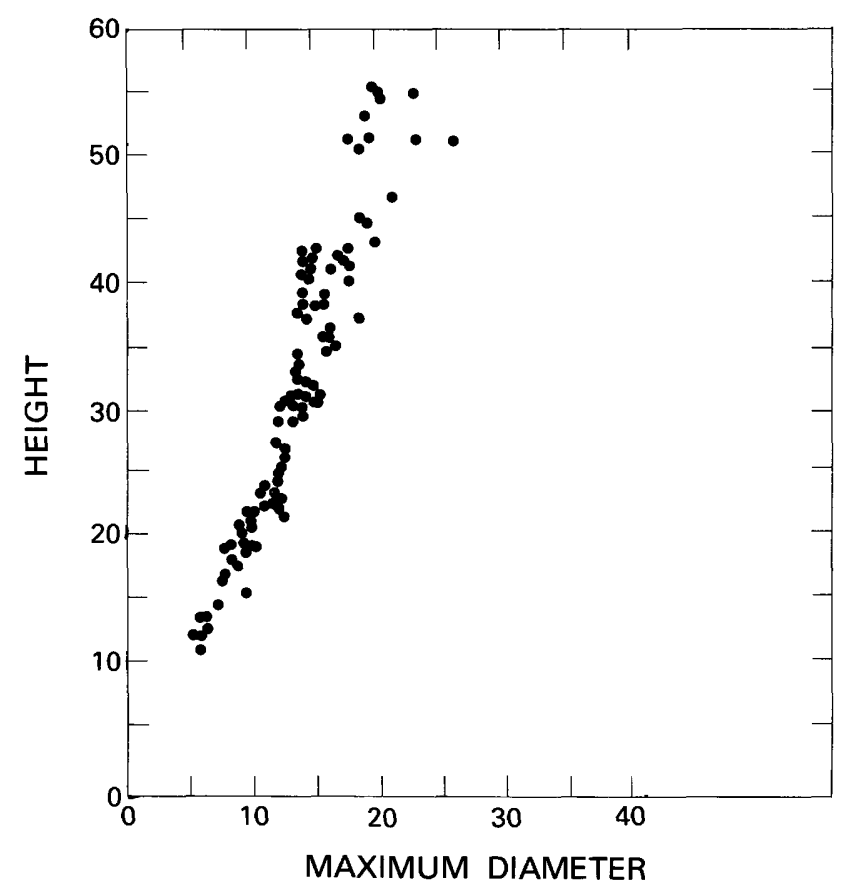

Figure 30.-Scatter diagram comparing height with width among selected specimens of Trochactaeon (Mexicotrochactaeon) coniformis (Böse).
Discussion.-In addition to the above description, one specimen possessed a narrow longitudinal groove on the interior inner surface of the body whorl that seemingly represents a muscle impression. The measurements were made on specimens from units 69,80 , and 98 of Wade's measured section along the Cardenas railroad in Mexico, published by Imlay (1944). These units contain all the "species" of Trochactaeon Böse described from the cut of the railway, 415 to $416 \mathrm{~km}$ from Tampico.

One of the most significant features of the forms collected in unit 80 is the extreme variability, which is caused primarily by the relative amount of overlap of one whorl onto the preceding one. This overlap is not only different in different specimens but often changes within one specimen (see pl. 10, fig. 9). The varying amount of overlap of the whorls is responsible for the differences in proportional height and size of the spire. The visible parts of the whorls are convex in the less overlapped and flat or even concave in the more overlapped whorls (compare figs. 12 and 17 on pl. 10). These differences were the criteria Böse used to distinguish his many species at Cardenas. As there is no other significant difference in Böse's "species," we agree with Myers (1968), who considered all of them, except for Böse's Actaeonella (Trochactaeon) aff. gigantea Sowerby, as belonging to one variable species, Actaeonella coniformis Böse.

The few specimens we have from Wade's unit 69 , which is $127.3 \mathrm{~m}$ lower in his section than unit 80 , do not have as strongly shouldered convex whorls. The whorls, however, do have shoulders, the subsutural ramps are steep, and the parietal ridge is strong; therefore, there is no reason to separate these specimens from Trochactaeon (Mexicotrochactaeon) coniformis. Although not separable as a distinct species, the specimens of unit 69 are not as variable as those in unit 80 and may be compared with the large varietal form named Actaeonella (Trochactaeon) acutissima Böse (1906, pl. 16). This observation is consistent with Böse's mention on his p. 17 that $A$. (Trochactaeon) acutissima occurs in the lower beds in the exposures along the railroad line near Cardenas, together with his Actaeonella (Trochactaeon) aff. gigantea Sowerby, which belongs to the herein described new species T. (Mexicotrochactaeon) rossi.

Several specimens were collected by Wade at the base of unit 98 of the Cardenas section, which he assigned a stratigraphic position considerably higher than unit 80 . These specimens resemble the forms from unit 69. According to Myers (1968), the Cardenas section shows repetition of beds because of a synclinal structure. Wade had not noted this structural complexity. Unit 98 probably has about the same stratigraphic position as unit 69 . 
The forms from Chiapas that Maldonado-Koerdell (1950) assigned to Actaeonella coniformis Böse, A. occidentalis Böse, $A$. inconstans Böse, A. planilateralis Böse, and his new subspecies Actaeonella (Trochactaeon) acutissima punctata belong to a single species that differs from $T$. (Mexicotrochactaeon) coniformis. For that species, the name $T$. (Neocylindrites) punctatus Maldonado-Koerdell is proposed (see p. 54).

Occurrence.-Mexico, State of San Luis Potosi, Cardenas Formation. Myers (1968, p. 76) listed occurrences through his Durania ojauchalensis, Arctostrea aquilerae, and Tampsia floriformis zones. The species is represented in collections of the U.S. Geological Survey from localities 152, 153, 156, 157.

Age.-Maastrichtian.

Types.-Hypotypes, USNM 306045-306062, UT(WSA 15554a.

Trochactaeon (Mexicotrochactaeon) burckhardti (Böse) Plate 12, figures 7-13; plate 13, figures 7-9

1923. Actaeonella (Trochactaeon) gigantea Sowerby sp. n. var. mexicana Böse, Mexico Inst. Geol. Bol. 42, p. 200, pl. 14, figs. 3-8.

1923. Actaeonella (Trochactaeon) Burckhardti Böse, Mexico lnst. Geol. Bol. 42, p. 202, pl. 14, figs. 9-14, pl. 15, figs. 1-11.

1923. Actaeonella (Trochactaeon) Burckhardti Böse n. var. obliqueplicata Bose, Mexico Inst. Geol. Bol. 42, p. 203, pl. 16, figs. 1-6.

1923. Actaeonella (Trochactaeon) pruniformis Böse, Mexico lnst. Geol. Bol. 42, p. 204, pl. 16, figs. 7-15, pl. 17, figs. 1-5.

1923. Actaeonella (Trochactaeon) Humboldti Böse, Mexico lnst. Geol. Bol. 42, p. 205, pl. 17, figs. 6-11.

1923. Actaeonella (Trochactaeon) sp. Böse, Mexico lnst. Geol. Bol. 42 , p. 206, pl. 17, figs. 12-14.

1923. Actaeonella (Trochactaeon) quadriplicata Böse, Mexico lnst. Geol. Bol. 42, p. 207, pl. 17, figs. 15-17.

1930. Actaeonella luciano Maury, Brazil Serv. Geol. Min., Mon. 8, p. 257 , pl. 10, figs. 1, 2, 6 .

1930. Actaeonella pompei Maury, Brazil Serv. Geol. Min., Mon. 8, p. 259 , pl. 10, fig. 7 .

1930. Actaeonella cf. silvai Maury, Brazil Serv. Geol. Min., Mon. 8, p. 263.

Diagnosis.-Body whorl strongly inflated in upper quarter, lower half tapering to slender base; columella proportionally short, parietal lip with a weak ridge on lower part.

Description.-Shells large, ovate; maximum diameter 46 to 58 percent of total height; spire variable in height, consisting of 6-7 whorls, early ones usually adapically concave in profile but later ones convex, profile rarely convex as a whole; whorls flat side and with a broad wrinkled outwardly inclined subsutural ramp. Body whorl 80 to 92 percent of total height, strongly inflated in upper quarter, flattened to slightly depressed medially, tapering and thinning anteriorly; surface with coarse prosocline growth lines becoming opisthocline over basal slope. Aperture elongate, proportionally broad; columella one-third of aperture height; columella with upper plait sharply upturned, lower two plaits weaker; columella below plaits as long as part with plaits; inductura with strongly prosocline outer margin that circumscribes columella; parietal lip thick, extends onto body whorl; low ridge above columella, thinning out nearly completely in middle within aperture, about two times thicker in the upper part than near columella; sections show plaits that gradually diminish in strength from first half of body whorl to outer half of penultimate whorl; a low palatal ridge occurs within penultimate whorl and in first half of body whorl; palatal walls of early whorls nearly completely resorbed.

Measurements (fig. 31).-The range of measurements of specimens studied is: $\mathrm{H}, 63-98.2 \mathrm{~mm}$; MD, 46-52 $\mathrm{mm}$; HB, 56-82 mm; PA $65^{\circ}-85^{\circ}$.

Discussion.-The seven "species" figured by Böse (1923) from Zumpango del Rio, Mexico, show very well the variation within the one species for which we select the name Trochactaeon (Mexicotrochactaeon) burckhardti (Böse); we place his other species in synonymy. As indicated on figure 31 , the height-width ratios are very variable. Unfortunately, the parietal lip seems not to be preserved in Böse's specimens; at least, it is not mentioned in his descriptions and is not recognizable on the figures. The general shape of the shellstheir low spire, convex body whorl, broad subsutural ramp, and proportionally slender columella-is charac-

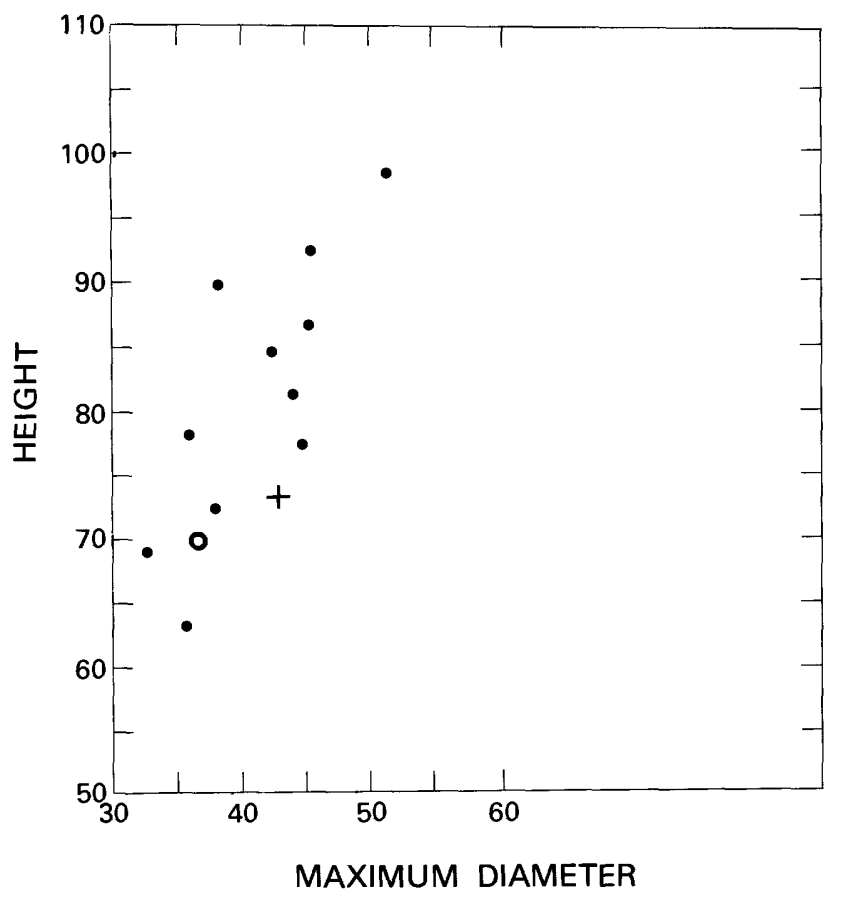

FIGURE 31.-Scatter diagram comparing height with width among selected specimens of $\bullet$, Trochactaeon (Mexitrochactaeon) burckhardti (Böse). 0, holotype of Actaeonella lucianoi Maury; + , holotype of A. pompei Maury. 
teristic of Trochactaeon (Mexicotrochactaeon) burckhardti and is in accordance with the shape of the Caribbean specimens described here and with that of the Brazilian Actaeonella lucianoi Maury (1930). Actaeonella pompei Maury (1930) was described from a single fragment, which, like $A$. lucianoi, also belongs to T. (Mexicotrochactaeon) burckhardti.

Among European species T. (Trochactaeon) sanctaecrucis (Futterer, 1892) is morphologically similar. This widely distributed species has, like $T$. (Mexicotrochactaeon) burckhardti, a strong thickening in the upper part of the parietal lip but differs in the thin lower part of the lip (Kollmann, 1967). There is no other significant difference in shell morphology between the two species. T. (Trochactaeon) galloprovincialis Cossmann (1897) is more convex in the lower part of the body whorl than is T. (Trochactaeon) burckhardti, has a thicker columella, and possesses a thin parietal lip, as far as it can be recognized from the completely recrystallized specimens from the type locality in the Barremian of southern France (Kollmann, 1967).

Occurrence.-Mexico: Böse's type material came from Tenantitlan near Zumpango de Rio in the State of Guerrero. Brazil: Maury's specimens came from Fazenda da Estiva near Tamandore, Pernambuco. Jamaica: Central inlier, Guinea Corn Formation, at localities 58-60, 64, 67; Maldon inlier, Maldon Limestone, at locality 119 .

Age. - "Emscherian" (probably Coniacian, according to Imlay, 1944, p. 1124) in Mexico; Emscherian in Brazil, according to Maury, 1930; Maastrichtian in Jamaica.

Types.-Hypotypes, USNM 306076-306080, 306088 . 306090 .

Trochactaeon (Mexicotrochactaeon) wrighti Sohl and Kollmann, n. sp. Plate 11, figures 8, 9; plate 12, figures 1-6, 10

Diagnosis.-A Mexicotrochactaeon with gently convex body whorl sides and an especially narrow elongate aperture.

Description.-Shells small to medium size, maximum diameter 42-79 percent of height. Spire with slightly concave to weakly convex sides; whorl sides convex, with a broad, collarlike steeply inclined ramp. Body whorl 74 to 83 percent of total height, shouldered in the upper fifth, conical to slightly convex below, with a shallow inflation in upper half. Growth lines fine. Aperture narrow and long. Columella one third of aperture height, median plait weakest; broad incision above columella, which may be carinated above. Parietal lip thick on anterior part, thinning out nearly completely near middle, thickening again on posterior part; margin of parietal lip nearly vertical on posterior part, becoming flatter on anterior third, circumscribing col- umella about one quarter of a turn and bending downwards, thus terminating columella. Columella usually resorbed internally on all whorls except the last; on penultimate whorl, only lower parts of palatal area resorbed; on earlier whorls, sides nearly completely resorbed.

Measurements (fig. 32).-The size range of $13 \mathrm{com}$ plete specimens is: $\mathrm{H}, 33.6-57.0 \mathrm{~mm}$; $\mathrm{MD}, \mathbf{1 4 . 5 - 2 8 . 8}$ $\mathrm{mm}$; HB, 26.5-45.0 mm; PA, $38^{\circ} 78^{\circ}$.

Discussion.-Trochactaeon (Mexicotrochactaeon) wrighti has features that seem similar to those of both T. (Neocylindrites) punctatus (Maldonado-Koerdell) and T. (Mexicotrochactaeon) coniformis. As do those of $T$. (Neocylindrites) punctatus, the shells possess both an especially elongate and narrow aperture and whorls that are not very convex below the shoulder. They are, however, similar to those of $T$. (Mexicotrochactaeon) coniformis in having an incision above the columella. This incision is especially deep and wide in the proportionally broad Jamaican specimen illustrated on plate 12 , figure 10. The less concave early whorls and flat sides of the body, however, distinguish the specimen from Böse's species. Specimens collected from the lower part of the Cardenas, Mexico, section (bed 51 of Imlay's, 1944, section) are closer to typical T. (Mexicotrochac-

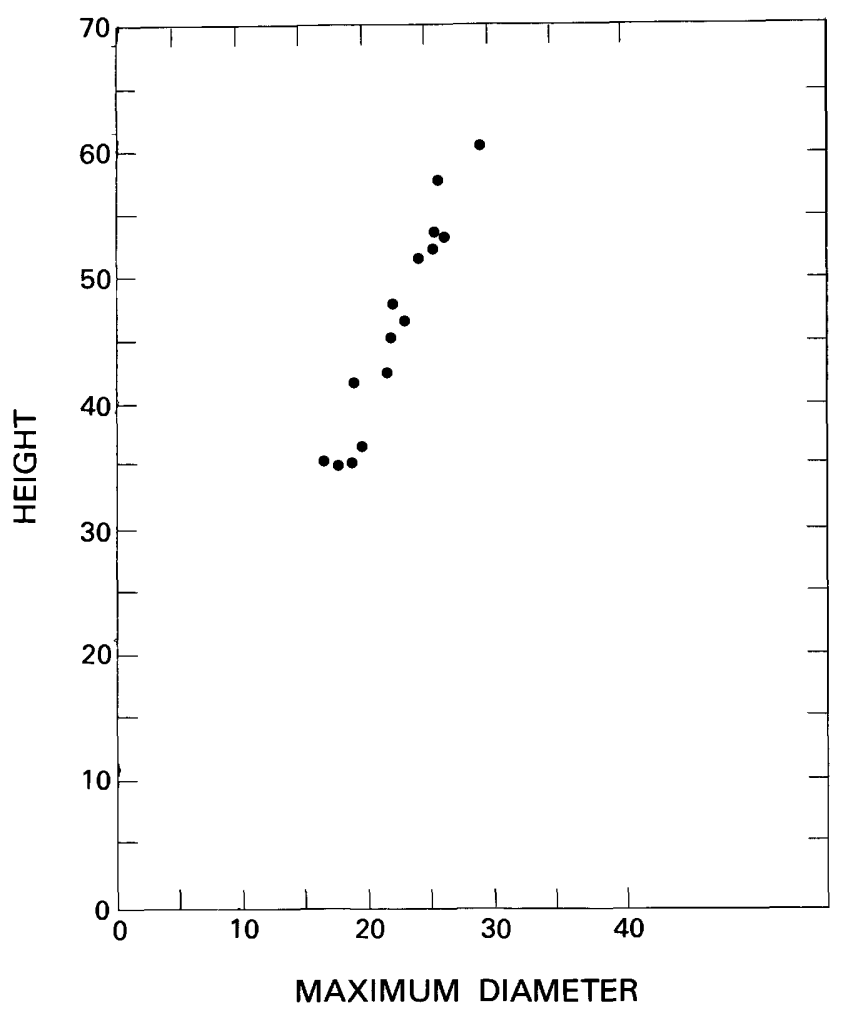

FIGURE 32.-Scatter diagram comparing height with width among selected specimens of Trochactaeon (Mexicotrochactaeon) wrighti Sohl and Kollmann, n. sp. 
taeon) coniformis. They possess slightly convex whorl sides and a distinct subsutural ramp. The incision above the columella is very deep and carinate, abuting the parietal lip (pl. 12, fig. 1).

Trochactaeon (Mexicotrochactaeon) wrighti possesses a proportionally shorter spire than do most other species of the subgenus. Although some specimens of both $T$. (Mexicotrochactaeon) granthamensis $\mathrm{n}$. sp. and $T$. (Mexicotrochactaeon) rossi $\mathrm{n}$. sp. may have a low spire, they are more obese, possessing a very convex-sided body whorl.

Occurrence.-Mexico: State of San Luis Potosi, Cardenas Formation, at localities 152, 155. Jamaica: Marchmont inlier, "Titanosarcolites limestone," at localities 93, 99.

Age.-Maastrichtian.

Types.-Holotype, USNM 306073; Paratypes, USNM 306067, 306068, 306070-306072, 306074, 306075.

Trochactaeon (Mexicotrochactaeon) palmeri Sohl and Kollmann, n. sp.

Plate 11, figure 5; plate 14, figures $1-5,8$

Diagnosis.-A T. (Mexicotrochactaeon) with a proportionally high spire and a parietal ridge that is reduced to a flat thickening at the aperture.

Description.-Shell of medium size; maximum diameter 45-55 percent of height, spire high, flat to slightly convex in profile; whorl sides generally convex with or without slight depression below shoulder; aperture broad but proportionally short; columella short, middle columellar plait weakest; parietal lip thick with curved rim; parietal ridge expressed only as a flat thickening at aperture, but stronger and with sharper crest inside first half of last whorl; palatal ridge low within last whorl; in penultimate whorl and earlier whorls, stronger resorption of side walls below palatal ridge than above; resorption of columella begins within last whorl, columella in earlier whorls smooth or with small round ridge.

Measurements (fig. 33).-The size range of the avail-

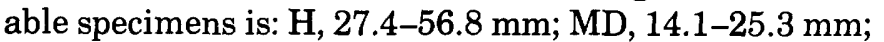
$\mathrm{HB}, 19.0-36.0 \mathrm{~mm}$; PA, $30^{\circ}-55^{\circ}$.

Discussion.-This species superficially resembles some specimens of Trochactaeon (Mexicotrochactaeon) coniformis (Böse) but differs by its proportionally broader whorls and the less prominent parietal ridge (compare pl. 10, fig. 6 , and pl. 14, fig. 4). The columellar plaits are resorbed within the last whorl, whereas the resorption in T. (Mexicotrochactaeon) coniformis starts with the beginning of the penultimate whorl.

Trechmann (1929) ascribed a specimen from the Blue Mountains, Jamaica, to Actaeonella (Trochactaeon) cf. variabilis (Böse). We have not examined the specimen, but the description suggests affinities to T. (Mexicotrochactaeon) palmeri.

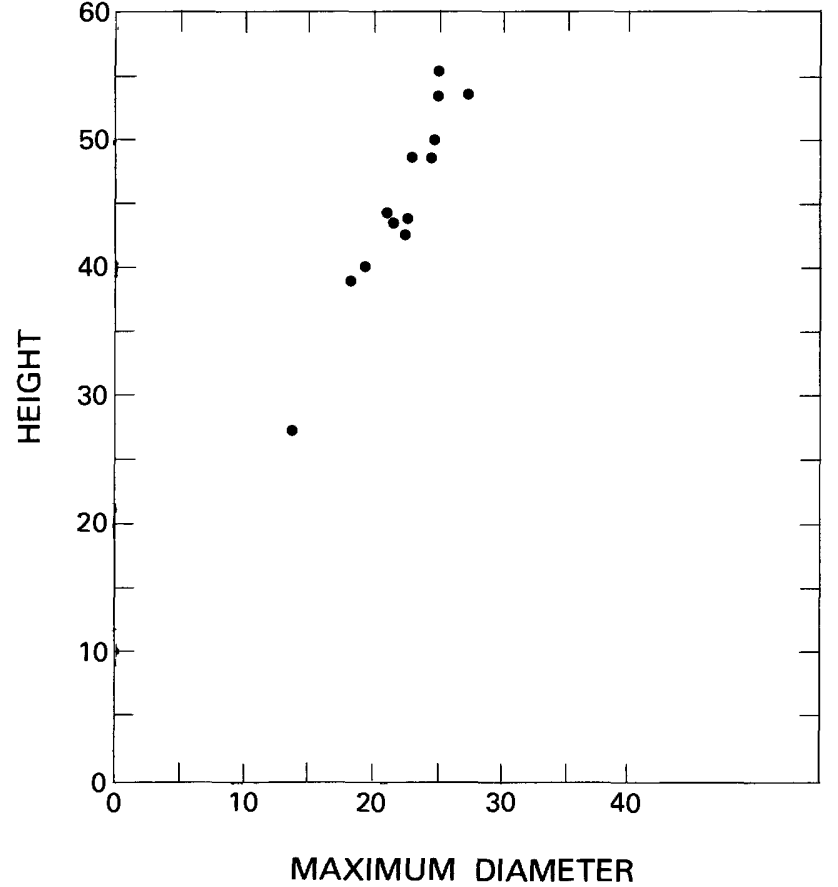

FIGURE 33.-Scatter diagram comparing height with width among selected specimens of Trochactaeon (Mexicotrochactaeon) palmeri Sohl and Kollmann, n. sp.

The species is named in honor of Robert O. Palmer, who made many of the collections from the Cretaceous of Cuba that provided fossils studied here.

Occurrence.-Jamaica: Jerusalem Mountain inlier, "Titanosarcolites limestone," at localities 108, 111; Central inlier, Guinea Corn Formation, at locality 65. Cuba: Santa Clara Province, Habana Formation, at localities 124, 126, 128, 129. Puerto Rico: San German Quadrangle, fossils in tuffs of the El Rayo Formation, at locality 42 .

Age.-Middle to late Maastrichtian.

Types.-Holotype, USNM 306098; paratypes, USNM 306063, 306095-306097, 306099, 306100.

Trochactaeon (Mexicotrochactaeon) teaensis Sohl and Kollmann, n. sp.

Plate 13, figures 1-3, 6, 14; plate 14, figures 6, 7, 9-16

Diagnosis.-A Mexicotrochactaeon with a proportionally high spire and a low rounded parietal ridge.

Description.-Shells of medium size, maximum diameter 44 to 54 percent of height; spire variable in height, convex in outline, whorls with an inclined, often indistinct collarlike ramp; shoulder variable with all transitions between virtual absence to slightly convex. Body whorl 66-83 percent of total shell height; sides below shoulder convex or with broad flat depression and angulated at junction with low columella. Aperture relatively broad and of medium height. Columella with 
middle plait weakest, part below plaits as high as distance between plaits; parietal ridge rounded, strongest in first half of last whorl, decreasing in strength at aperture; palatal ridge strong in first half of last whorl, but area below ridge resorbed on penultimate whorl; in earlier whorls, resorption occurs also on upper part of palatal walls; columella with strong medial ridge in resorbed parts.

Measurements (in mm).-H, 18.6-66.0; MD, 8.8-30.2; $\mathrm{HB}, 15.5-51$; PA, $30^{\circ}-60^{\circ}$.

Discussion.-Trochactaeon (Mexicotrochactaeon) teaensis is a very variable species; it possesses characters suggesting that it is intermediate in form between $T$. (Mexicotrochactaeon) rossi and T. (Mexicotrochactaeon) wrighti. It is like $T$. (Mexicotrochactaeon) rossi in having evenly convex whorls and a broad, rounded, low parietal ridge. It is similar to $T$. (Mexicotrochactaeon) wrighti in its width of whorl and in the character of the shoulder that occurs on most specimens; however, the whorls are proportionally longer.

Trochactaeon (Mexicotrochactaeon) teaensis occurs in rocks of Maastrichtian Age from Puerto Rico to Mexico. It is very abundant in the Tea syncline near San German, Puerto Rico.

Occurrence.-Puerto Rico: San German Quadrangle, limestone lentils within the El Rayo Formation, at locality 48. Jamaica: Jerusalem Mountain inlier, "Titanosarcolites limestone," at locality 109. Mexico: State of San Luis Potosi, Cardenas Formation, at localities 155, 156, 157.

Age--Middle to late Maastrichtian.

Types.-Holotype, USNM 306105; paratypes, USNM 306081-306085, 306101-306104, 306106.

\footnotetext{
Trochactaeon (Mexicotrochactaeon) granthamensis Sohl and Kollman, n. sp.

Plate 13, figures 10-13; plate 15, figures 1-11
}

Diagnosis.-Variably high spired shell with a columella that is bordered above, first by a deep constriction and then by a ridge; parietal lip thickened in upper part.

Description.-Shells of small to medium size; maximum diameter 43 to 57 percent of total height; spire usually high but variable, slightly concave to convex in profile and consisting of 7 to 8 whorls; whorl sides flat in small specimens, convex in large ones; all whorls with a broad, inflated, but little inclined subsutural ramp. Body whorl 62 to 89 percent of total height, convex in outline with greatest diameter in posterior third, convex below and tapering towards very narrow base. Opisthocyrt growth lines strongly curve backwards over the ramp. Growth lines occasionally develop a narrow sinus over upper part of whorl. Aperture broad with a proportionally long columella; uppermost columellar plait acute and bent upwards; plaits decreasing in size anteriorly; part of columella below plaits about half total height; deep incision above columella bordered posteriorly by parietal ridge; this ridge extends out from margin of columellar lip but becomes more prominent inside shell and is present throughout last whorl; thickening on upper part of parietal lip prominent. In early growth stage, deep constriction in middle of parietal lip; low palatal ridge in penultimate whorl at later stage.

Measurements (fig. 34).-The largest available, but incomplete, specimen, has an estimated height of nearly $100 \mathrm{~mm}$ and a maximum diameter of $51 \mathrm{~mm}$. Most commonly, shells range from 60 to $75 \mathrm{~mm}$ in height and 27 to $38 \mathrm{~mm}$ in diameter.

Discussion.-This species varies considerably in shell proportion. High-spired forms tend to have a more slender outline whereas those having a low spire possess a

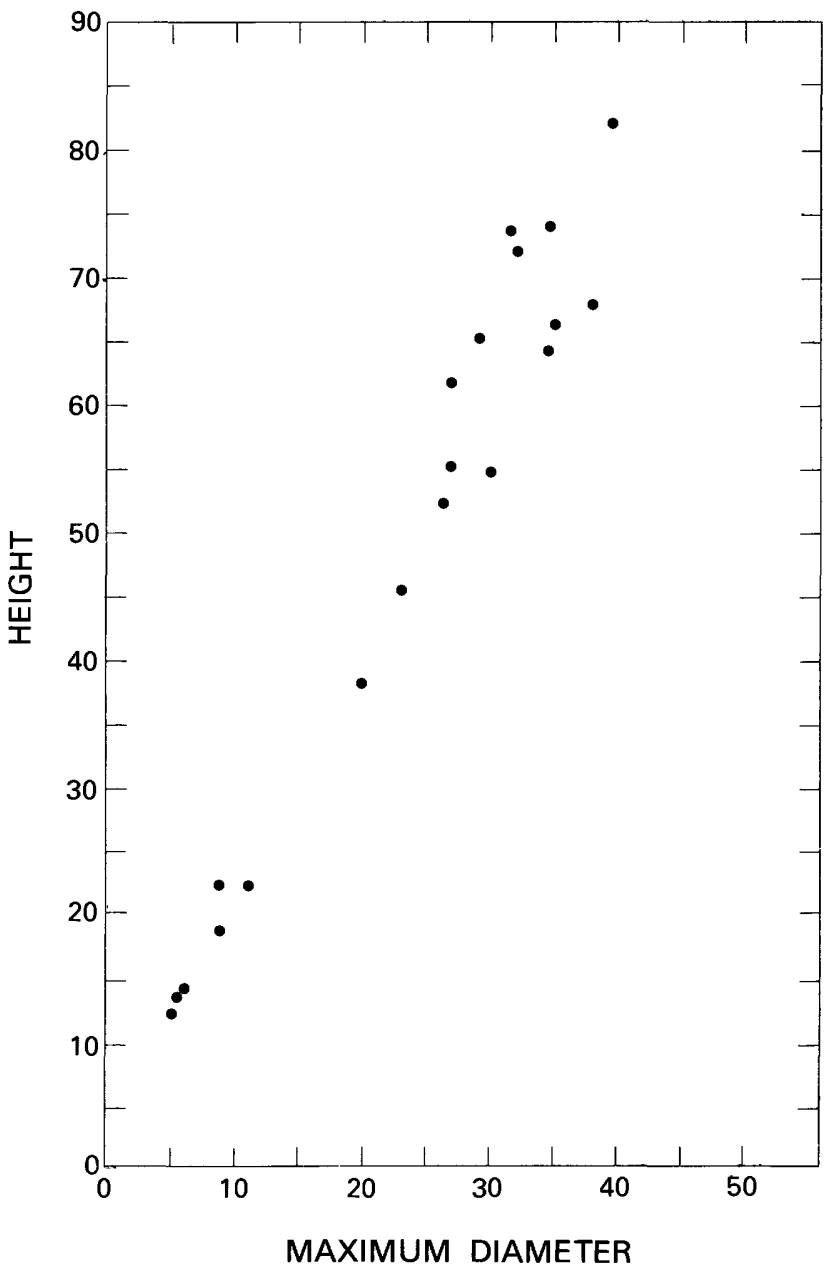

FiguRE 34.-Scatter diagram comparing height with width among selected specimens of Trochactaeon (Mexicotrochactaeon) granthamensis Sohl and Kollmann, n. sp. 
more obese and rounded body whorl (pl. 15, fig. 1). In most larger specimens, the shell is quite thin near the aperture; thus, the body whorl gives a wrinkled appearance in part because of crushing and part because of accentuation of the growth lines (pl. 15, fig. 7). Of all the species dealt with in this work, this species contains the largest number of individuals showing shellrepair phenomena. Although breaks may be common at almost any stage, the specimen figured on plate 15 , figure 8 , shows extreme injury. In this specimen, the body whorl has been broken back for a distance of almost half a turn and then reformed at an offset position.

Occurrence.-Jamaica: Central inlier, Guinea Corn Formation, at localities $61,62,64,68,68 \mathrm{a}, 69,76$, and 79; Marchmont inlier, "Titanosarcolites limestone," at locality 106.

Age.-Middle Maastrichtian.

Types.-Holotype, USNM 306115; paratypes, USNM 306091-306094, 306108-306114.

Trochactaeon (Mexicotrochactaeon) rossi Sohl and Kollmann, n. sp. Plate 13, figures 4,5 ; plate 16 , figures $1-9$

1906. Actaeonella (Trochactaeon) aff. gigantea Sowerby. Böse, Inst. Geol. Mexico Bol. 24, p. 82, pl. 17, fig. 1.

1968. Actaeonella coniformis Böse. Myers, (in part) Mexico Univ. Nac. Autónoma, Inst. Geol., Paleontología Mexicana, No. 24, p. 75, pl. 7, figs.4, ?5: not fig. 3 (T.(Mexicotrochactaeon) coniformis)

Diagnosis.-Spire and body whorl equally convex in profile, subsutural ramp collarlike; parietal lip with broad thickening in lower part.

Description.-Small to large elongate oviform shells consisting of 8 to 9 fairly convex high whorls with strongly inclined collarlike subsutural ramps that become indistinct on larger specimens. Maximum diameter 37 to 54 percent of total height and occurs at middle of shell, which is nearly symmetrically biconvex in large- and medium-sized specimens; in small specimens, spire may be slightly concave. Body whorl 58 to 84 percent of total height; aperture long, slightly broader in lower part; columella proportionally long, thin, and distinctly separated from convex whorl sides above; columellar plaits weak but equal in adult specimens; parietal ridge begins within aperture as rounded but distinct thickening of lower third of parietal lip, but parietal ridge absent in early growth stages. Columellar plaits decrease in size within body whorl and are lost in earlier formed whorls where columella is highly resorbed and shows only a foldlike ridge at midheight; palatal ridge present on penultimate whorl and on most of body whorl but does not reach aperture.

Measurements (fig. 35). - The size range of the many specimens studied is: $\mathrm{H}, 22-86 \mathrm{~mm}$ (a large fragment is estimated to represent a shell about $130 \mathrm{~mm}$ high); $\mathrm{MD}, 10.7-50.2 \mathrm{~mm}$; BW, $19.7-88 \mathrm{~mm}$; $\mathrm{PA} 34^{\circ}-60^{\circ}$.

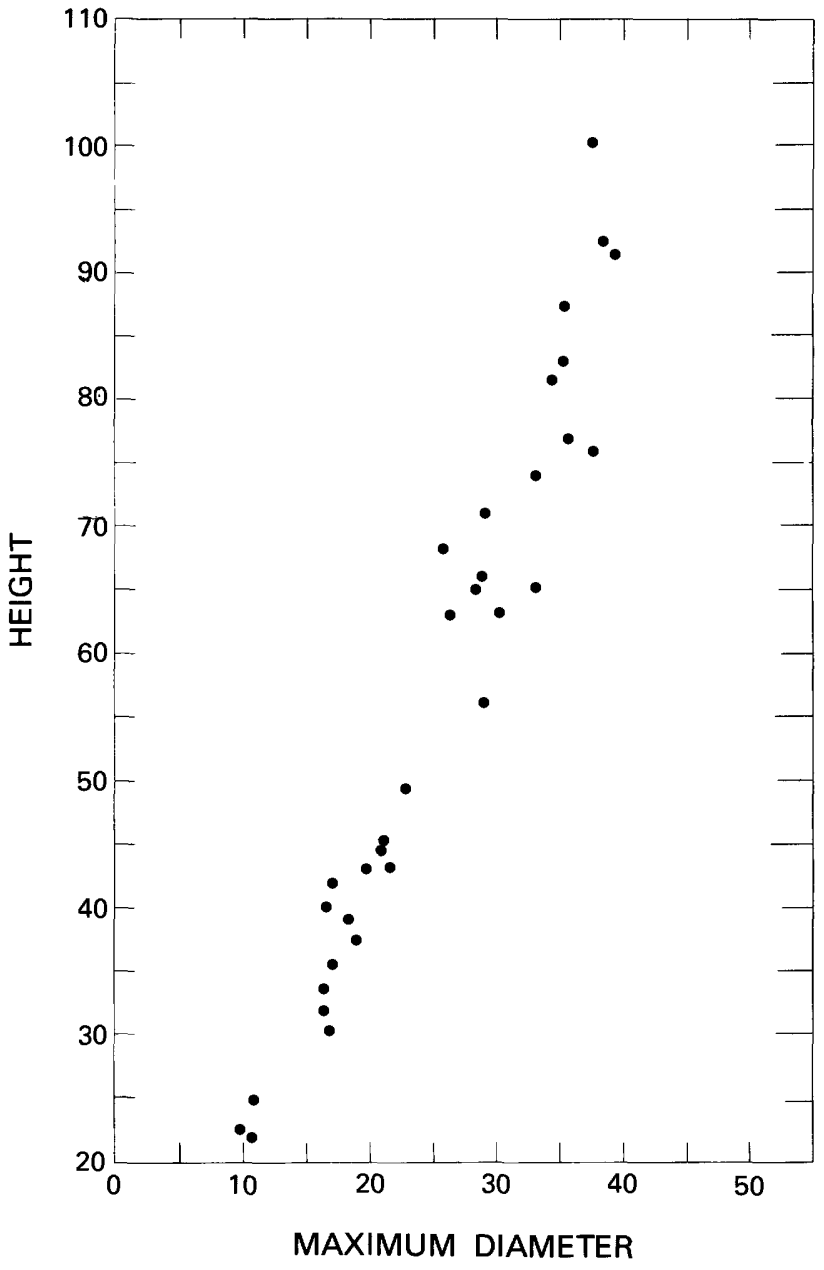

FIGURE 35.-Scatter diagram comparing height with width among selected specimens of Trochactaeon (Mexicotrochactaeon) rossi Sohl and Kollmann, n. sp.

Discussion.-Shells of this species vary widely in their proportions, even specimens from the same locality. Common to all larger specimens is the equal convexity of both the body-whorl sides and the spire and also the thickening of the lower part of the parietal lip. Collections containing small specimens show that convex spires predominate but that a few specimens may have a concave spire profile. As the parietal lip in small specimens shows no thickening at all, there is some question whether they should be included in this species. However, as most of them show the same external shell features, we have included them. We also include the specimen that Böse assigned to Actaeonella (Trochactaeon) aff. gigantea Sowerby because it has an evenly rounded last whorl and a spire with convex sides, but the spire is lower than in most other specimens. Myers (1968, pl. 17, fig. 4) figured a large specimen that should be included in this species as it shows a thickening of the parietal lip. Another specimen fig- 
ured by Myers (1968, pl. 17, fig. 5) is a higher spired form, which may belong to the same species. Myers assigned both these specimens to Actaeonella coniformis Böse, but he did not include Böse's Actaeonella (Trochactaeon) aff. gigantea Sowerby in his synonymy. This suggests that he considered that form to be different from all the other "species" of Böse.

Trochactaeon (Mexicotrochactaeon) rossi may be distinguished by the strong convexity of the body whorl and by the thick swelling in the upper part of the parietal lip. Other species having a similar high spire may be distinguished by their lack of the very broad and less inclined subsutural ramp. The shell of $T$. (Mexicotrochactaeon) granthamensis is not as broad, the whorls are narrow, and the parietal ridge is sharper.

The species is named in honor of William $O$. Ross of the U.S. Geological Survey, who assisted in collecting and preparation of much of the material upon which this study is based.

Occurrence.-Mexico: State of San Luis Potosi, Cardenas Formation (upper part), according to Myers (1968). Jamaica: Marchmont inlier, "Titanosarcolites Limestone," at localities 99, 102a, 105a; Central inlier, Guinea Corn Formation, at localities 73, 74, 78, 82, 84, 87, 89. Cuba: Questionable occurrence in the Habana Formation, Habana Province, at locality 126.

Age.-Middle Maastrichtian.

Types.-Holotype, USNM 306120; paratypes, USNM 306086, 306087, 306116-306119.

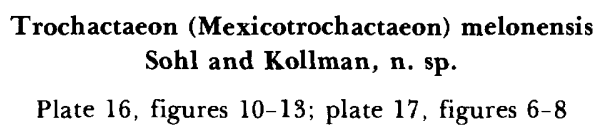

Diagnosis.-A Mexicotrochactaeon with a high spire and an exceptionally developed parietal ridge.

Description.-Oviform shells of medium size, maximum diameter about half total height; spire variable, mostly high, convex in profile; whorl sides slightly convex, subsutural ramp narrow and inclined. Body whorl convex, occasionally indistinctly shouldered; base well rounded. Aperture incompletely known, broad, and comparatively low; middle of three columellar plaits weakest; part of columella below plaits as high as distance between plaits; parietal lip with a broadly expanded edge inclined $35^{\circ}$ to shell axis; parietal lip thin except for a strong round-topped ridge that ends within aperture; ridge situated higher on parietal lip in earlier whorls than on last whorl. Sectioned shells show that wider shells possess a stronger palatal ridge; side walls thick and not resorbed in earlier whorls, but columella is resorbed.

Measurements.-Most available specimens are incomplete, but large specimens approach $80 \mathrm{~mm}$ in height, with a maximum diameter near $40 \mathrm{~mm}$. One small specimen measures $35 \mathrm{~mm}$ in height and $18 \mathrm{~mm}$ in diameter. The pleural angle of small stages is near $80^{\circ}$ but decreases in latest growth stages to $30^{\circ}-35^{\circ}$.

Discussion.-This species is moderately variable in the proportional height of the spire and in whorl outline. In most specimens, the spire height approaches or even occasionally exceeds half the total shell length. The two specimens figured on plate 16, figs. 11 and 13 , adequately express the range of body-whorl convexity, one being well rounded, whereas the other approaches a cylindrical upper whorl profile. This species resembles $T$. (Mexicotrochactaeon) rossi in its general appearance, but its body whorl is more evenly rounded, broader, and proportionally not as high. T. (Mexicotrochactaeon) melonensis has an extraordinarily strong parietal ridge, which distinguishes it from other species that possess broad whorls. T. (Trochactaeon) obtusus (Zekeli), which has been recorded from several localities in Austria and Yugoslavia (Kollmann, 1967), is similar in its overall shell form but lacks a parietal ridge and therefore belongs to the subgenus $T$. (Trochactaeon).

Occurrence.-Puerto Rico: Melones Limestone, Cabo Rojo Quadrangle, at locality 13, and Puerto Real Quadrangle, at localities 31 and 33 .

Age.-Early Maastrichtian.

Types.-Holotype, USNM 306123; paratype, USNM 306121, 306122, 306129, 306130.

Trochactaeon (Mexicotrochactaeon) spp.

Discussion.-Specifically indeterminate specimens occur at many localities. Most probably belong to species already described here, but their state of preservation precludes precise placement. They are included here, as many are the only record of the genus in certain Maastrichtian rock units.

Occurrence.-Puerto Rico: Melones Limestone, Cabo Rojo Quadrangle, at locality 14; El Rayo Formation, San German Quadrangle, at locality 50; Cotui Limestone, San German Quadrangle, at locality 46.

Jamaica: Guinea Corn Formation, Central inlier, at localities 54-56, 62-64, 66, 68, 72, 77, 81, 82, 85, 88, 90, and 91; Titanosarcolites-bearing limestone, Marchmont inlier, at localities $93,96,97$, and 106, Jerusalem Mountain inlier, at localities 110,111, 114, and 115; Maldon Limestone, Maldon inlier, at localities 118, 119; Vaughansfield Limestone, Maldon inlier, at locality 117.

$$
\begin{aligned}
& \text { Genus Actaeonella d'Orbigny, I842 } \\
& \text { (Synonym Volvulina Stoliczka, I865) }
\end{aligned}
$$

Type by subsequent designation (Hermannsen, 1846) Volvaria laevis Sowerby.

Diagnosis. - With the addition that rarely only two columellar plications may be present, Meek's (1863, p. 89) characterization of the genus remains pertinent: 
Shell ovate-volvuliform, rather thick, involute, more or less attenuate above, widest below the middle-entirely without any traces of a spire. Surface nearly smooth. Aperture very narrow, arcuate, and equalling the greatest length of the shell. Outer lip smooth, generally rather obtuse. Inner lip thickened near the base of the aperture, and twisted outwards so as to form on the columella three prominent revolving folds; also usually a little thickened at the summit of the aperture.

Discussion.-D'Orbigny (1842) in describing the genus Actaeonella failed to designate a type species. The first designation of a type species was that of Hermannsen, who in 1846 selected Volvaria laevis J. de C. Sowerby from the Santonian to Campanian of the eastern Alps. Meek (1863) subsequently cited the same species as type but failed to cite Hermannsen as first subsequent designator; however, he did give a full reference to Sowerby's work. From this point onward, various errors in citation of the type species entered into the synonymic history. The first major departure was Cossmann's (1895) designation of Actaeonella laevis d'Orbigny (1842), not Sowerby, as type. D'Orbigny's species, based upon specimens from the Turonian of Uchaux, France, are distinct from Sowerby's species. Evidently, Cossmann was ignorant of the existence of Sowerby's figures of $V$. laevis, as he neither cited or discussed them but proposed the name A. terebrellum for the Alpine species. In the following year, Cossmann (1896) cited A. laevis (Sowerby) as a valid name and placed his A. terebrellum in synonymy. At the same time, he recognized the separation of d'Orbigny's $A$. laevis from Sowerby's species by erecting a new species, $A$. uchauxensis. In a separate paper, read in April 1896 but not published until 1896, he used d'Orbigny's A. laevis as the basis for description of yet another species, $A$. grossouvrei. Thus, to this point, the synonymy of these two species is as follows:

\footnotetext{
Sowerby's laevis

1832 Volvaria laevis Sowerby

1846 Actaeonella laevis Hermannsen

1863 Actaeonella laevis Meek

1895 Acteonella terebrellum Cossman

1896 Acteonella laevis Cossmann

d'Orbigny's laevis

1850 Acteonella laevis (Sowerby) d'Orbigny

1895 Acteonella uchauxensis Cossmann

1896 Acteonella grossouvrei Cossmann
}

Cossmann and several subsequent authors ignored Hermannsen's and Meek's earlier designations and continued to cite $A$. uchauxensis as the type of the genus. This stand has been supported by Nuttall (1969) and Nuttall and Leong (1972). In his request to the International Commission on Zoological Nomenclature, Nuttall (1969) argued that compilations such as that of Zilch (1959) and Pchelintsev and Korobkov (1960) cited Acteonella uchauxensis Cossmann as the type species. Subsequently, Nuttall and Leong (1972) cited Article 70 of the Code, which deals with misidentified type species, as support for the original Nuttall proposal.

In contrast to Nuttall's opinion, we see no reason to reject Hermannsen's (1846) explicit designation of Actaeonella laevis (Sowerby) as the type species. That Hermannsen did not cite the plate and figures provided by Sowerby is no reason to believe that he meant Actaeonella laevis d'Orbigny (=A. uchauxensis) to be considered the type species, and certainly no proof, as Nuttall believes, that Hermannsen misidentified d'Orbigny's species. Rather, it seems clear that if misidentification is the charge, it is Cossmann who must bear the stigma. In 1895, when he designated d'Orbigny's species, which later he named $A$. uchauxensis, Cossmann was certainly not aware that $A$. laevis (Sowerby) existed and had been previously designated as the type species of Actaeonella. The fact that such subsequent compilers as Zilch and Pchelintsev and Korobkov have in error followed Cossmann's designation does not seem a compelling reason to ignore the primary literature and perpetuate misinterpretation of the record. Obviously, subsequent compilers have followed Cossmann's 1895 designation without independently searching the literature. In other type designations, such as those for Euchelus Phillipi, Calliostoma Swainson, and Rimella Agassiz, they have accepted Hermannsen as a source. Thus, if Hermannsen cannot be ignored as a source of type designation for these genera, he cannot be ignored for designation of the type species of Actaeonella.

Attempts have been made to subdivide Actaeonella. The most diverse subdivision is that proposed by Djalilov (1972), who suggested the following taxa:

Subgenus Sogdianella (Type species: Actaeonella supernata Pchelintsev, 1953; Turonian; Transcaucasus, USSR).

Subgenus Pchelincevella (Type species: Actaeonella caucasica Zekeli, 1852; Coniacian, Transcaucasus, USSR).

Genus Ovactaeonella (Type species: Ovactaeonella ferganica Djalilov, 1972, Coniacian; Fergana, Kuraminskiy Range, USSR).

In addition to the above and in the same year, Hacobjan (1972) proposed the genus Omphaloactaeonella (type species Actaeonella ovata Pchelintsev, 1953; Turonian, Armenia).

Kollmann and Sohl (1980) have presented evidence for the inclusion of Sogdianella in the family Itieriidae of the Nerineacea, rather than the Actaeonellidae. Of the remander, Ovactaeonella and Omphaloactaeonella, both proposed in 1972, seem to represent either the same or an overlapping generic concept. Djalilov and Hacobjan included virtually the same species in these 
two genera, but in subsequent publications have maintained the independent generic names. In both genera, however, the included species possess the hollow columella and central pillar of the Itieriidae rather than the Actaeonellidae. Thus, we are not considering them further, and they are herewith transferred out of the Actaeonellidae in the accompanying species catalogue.

The only remaining taxon is Pchelinsevella Djalilov (1972, p. 22) which is "distinguished from the nominate subgenus by the amygdaloid, squatter shell" (translation). The distinction of this subgenus seems vague to us, of no practical value, and is not accepted here.

The evolution, distribution, and life habits of Actaeonella are discussed elsewhere in this paper. Some features of shell morphology, not elsewhere touched upon, need special mention. The first is external sculpture. The vast majority of actaeonellids possess a smooth surface marked only by fine growth lines. A few species such as Actaeonella decorata Hacobjan, A. ornata Pchelintsev, and A. khalilovi Aliev from the Cenomanian of the Armenian SSR, show spiral sculpture consisting either of incised lines or raised coarse spiral cords interrupted by transverse swellings that lend a spirally elongate noded appearance to the cords.

Shells of Actaeonella are seldom bored. One of the few exceptions found in our material is figured on plate 21 , figure 15. Likewise, lack of epibiont encrustation and lack of evidence of shell breakage and repair support the interpretation of an infaunal habit.

Internally, Actaeonella lacks evidence of shell-wall thinning and rarely shows secondary shell deposition in parts of the shell that is so common in Trochactaeon shells. One especially unusual character shown by two species described here (A. robinsoni and A. cubensis) is the presence of only two columellar plications. We know of no other species possessing this feature.

Actaeonella pecosensis Stanton

Plate 18, figures 9-14; plate 20, figure 10

1947. Actaeonella pecosensis Stanton, U.S. Geol. Survey Paper 211 , p. 110 , pl. 67 , figs. $2,5,6,8,9$

Diagnosis. -A high slender Actaeonella with evenly convex sides and acute posterior tip; columella with an additional weak fourth plait below three primary plaits.

Description. - "Shell of moderate size, slender fusiform, with the spire entirely concealed and the aperture extending the full length of the shell; greatest breadth of shell a little in advance of the middle, from which the shell gradually tapers to the acute posterior end which has an apical angle of about $30^{\circ}$; anterior end broader, more abruptly narrowed, and obliquely truncate or slightly emarginate in front; surface smooth, not even showing growth lines on the best preserved specimens studied; inner lip thickened toward the front and bearing three strong spiral folds of which the posterior fold is most prominent. The elevation on which the folds are borne is continued as a narrower rounded ridge on the back of the last whorl where it borders the anterior end of the shell. The aperture is very narrow, its widest part being near the columellar folds" (Stanton, 1947, p. 110).

Additional description.-Maximum diameter 29-37 percent of total height. Columella proportionally long, in late growth stages bears three plaits of about equal strength, with a fourth very weak plait very close but anterior to the third plait; columella below three upper plaits slightly more inclined towards shell axis than above; lateral edge of columella thickened, inclined about $40^{\circ}$ toward axis, upper two plaits extend towards this edge, but lower ones end well before edge. Shell base unknown.

Measurements (fig. 36).-The holotype (USNM 77560) is $43 \mathrm{~mm}$ high and has a maximum diameter of $14 \mathrm{~mm}$. Other specimens reach a maximum height of $60.5 \mathrm{~mm}$ and have a maximum diameter of $20.5 \mathrm{~mm}$. The pleural angle of all specimens ranges from $32^{\circ}$ to $45^{\circ}$.

Discussion.-Cut sections (pl. 20, fig. 10; pl. 18, fig. 14) show that the proportional maximum shell diameter is

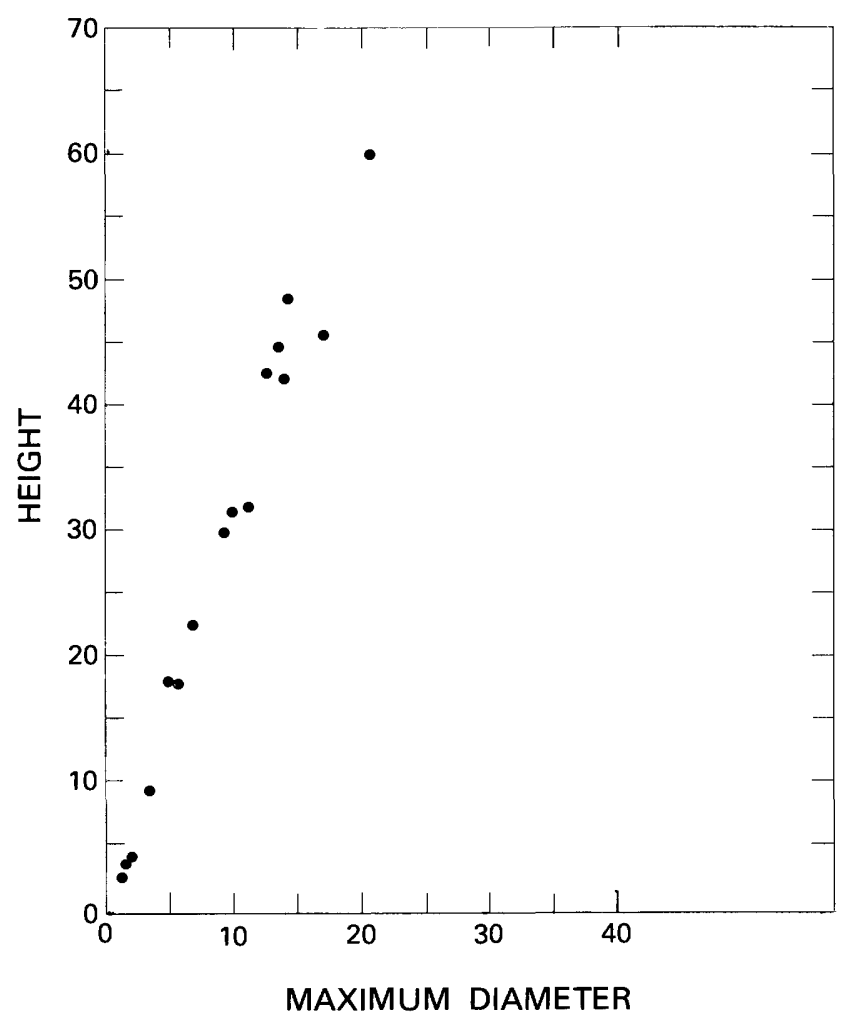

FIGURE 36.-Scatter diagram comparing height with width among selected specimens of Actaeonella pecosensis Stanton. 
greater in small growth stages $(\mathrm{H} / \mathrm{D}=2.5$ to 3$)$. In smaller specimens, the columellar length is also proportionally greater than in larger specimens. No development of the weaker fourth columellar plait seems to have taken place in these early growth stages. Thus, in early stages, individuals can hardly be distinguished from Actaeonella delgadoi Choffat. Larger specimens of A. delgadoi have a higher maximum diameter than large specimens of $A$. pecosensis and also a more obtuse posterior tip.

The species is abundant in the upper part of the Devils River Limestone of the margins of the Maverick Basin in Texas. Stanton (1947, p. 110) noted that it is a common associate of Nerinea riograndensis.

Occurrence.-Texas:Devils River Limestone (upper part), at localities 134, 139, and Edwards Limestone, at localities 132, 146.

Age.-Middle to late Albian.

Types.-Holotype, USNM, 77560; paratypes, USNM 77561a-b, 103173; hypotypes, USNM 306138, 306139, UT1036 TX6.

Actaeonella delgadoi Choffat, 1901

Plate 18, figures $17-20$

1901. Actaeonella delgadoi Choffat, Faune crétacique du Portugal, v. 1, p. 109, pl. 1, figs. 1-6.

1916. Actaeonella gracilis Douvillé, Acad. Sci. Inst. France Mém., ser. 2, v. 54 , no. 1, p. 147 , pl. 18, fig. 34.

1955. Acteonella gracilis Douvillé. Mahmoud, lnst. Désert Egypte Pub. 8, p. 155, pl. 17, figs. 29-31.

1963. Actaeonella gracilis Douvillé. Abbass, [Cairo] Geol. Mus., Palaeont. Ser., Mon. 2, p. 105.

1972. Acteonella grossouvrei Cossmann. Collignon, Morocco Serv. Géol. Notes et Mém. 228, p. 18, pl. 3, figs. 12-14.

1972. Actaeonella (Pchelincevella) delgadoi Choffat. Djalilov, Paleont. Zhur. no. 1, p. 14.

1977. Acteonella (Pchelincevella) delgadoi Choffat. Djalilov, Akad. Nauk Tadzhakstan SSR, p. 116.

Description.-Shells small, maximum diameter 38 to 41 percent of total height; sides subcylindrical, slightly convex with a pleural angle of $75^{\circ}$ to $90^{\circ}$; basal part rounded; aperture narrow; columella proportionally long, about 20 percent of total height, very thick and separated from parietal region by a deep incision; three plaits of columella decrease in strength anteriorly, upper and middle plaits concave on their upper surface; occasionally, a faint fourth plait appears below anteriormost one, which is only visible between half and three-quarters of a whorl behind aperture. Laterally, edge of columella bends strongly downward; edge either reflected or elevated; upper two plaits end at this rim, lower plait ends somewhat before edge.

Measurements (fig. 37).-Available specimens range from 21.6 to $29.2 \mathrm{~mm}$ in height and 8.2 to $14.2 \mathrm{~mm}$ in maximum diameter.

Discussion.-Actaeonella sublaevis d'Orbigny has a

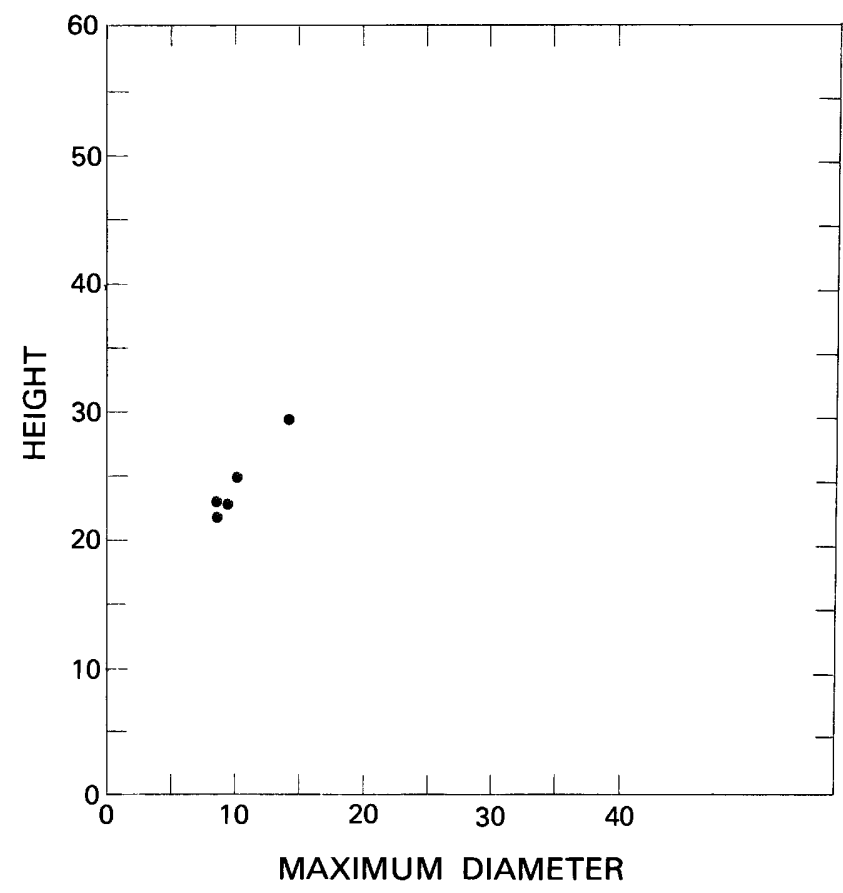

FIGURE 37.-Scatter diagram comparing height with width among selected specimens of Actaeonella delgadoi Choffat.

columellar form similar to that of $A$. delgadoi, but the profile of the upper part of the shell is strongly concave. In addition, small shells of $A$. sublaevis are inflated anteriorly and drawn out to an acute posterior tip (see Briart and Cornet, 1865), but large specimens have a more cylindrical shape. A. pecosensis Stanton differs in possessing a more acute apical tip, a shell that is constantly convex throughout with only a small medial constriction, and a proportionally shorter columella.

Occurrence.-Texas: Glen Rose Formation, "Thorp Springs Limestone Member," at locality 145, and from an unspecified locality in the Walnut Formation (specimens from the USNM Renfro Collection). Also, Portugal, Egypt (Massif de Moghara), and Madagascar.

Age.-Early and middle Albian in Texas, but Albian to Cenomanian elsewhere.

Types.-Hypotypes, USNM 306140-306143.

\section{Actaeonella cf. A. sublaevis Briart and Cornet}

Plate 18, figures 21, 22

1865. Actaeonella sublaevis Briart and Cornet, Acad. Roy. Sci., Lettres, et Beaux Arts Belgique Mém., v. 34, p. 42, pl. 3, figs. 15-16. 1939. Actaeonella (Volvaria) sublaevis Briart and Cornet. Marlière, Roy. Hist. Nat. Belgique Mém. 89, p. 147, pl. 8, fig. 10a, b. 1970. Actaeonella delgadoi Choffat. Wolff, Univ. Munich, Disiert., p. 142 , pl. 7 , figs. 6-7.

1976. Actaeonella sublaevis Briart and Cornet. Kollmann and Yochelson Naturhist. Mus., Wien Annal., v. 80, p. 186, pl. 6, figs. 55-57. 
Description.-Shell large, lower part with weakly convex sides. At about two-thirds of total shell height as measured from base, sides turn abruptly inward towards axis; because inclination toward axis lessens higher on shell, whorl sides below posterior tip are strongly concave. Columella is proportionally high, upper two of three plaits are sharp and bent upwards, lowermost plait is rounded on top.

Discussion.-Only fragments and steinkerns with partly preserved shells of this large Actaeonella are present in our collections. Because of the poor state of preservation of all available material, assignment to Actaeonella sublaevis is tentative and affords no basis for further speculation. The subcylindrical lower part of the shell and the strongly concave sides of the upper part (pl. 18, fig. 21) are features found in large specimens of Actaeonella sublaevis, especially the specimen illustrated by Marlière (1939) and Kollmann (1976). This specimen has a total height of $38 \mathrm{~mm}$, which is only one-third that of our largest specimen. Actaeonella delgadoi differs in having evenly convex whorls but is closely related to Actaeonella sublaevis.

Occurrence.-Belgium: Meule de Bracquegnies. Austria: the species has been found at several localities in the eastern Alps (Wolff, 1970; Kollmann, 1967, 1976). Texas: Buda Limestone, at localities 133 and 144; Edwards Limestone, at locality 146.

Age.-middle Albian to early Cenomanian.

Types.-Hypotypes, USNM 306144, UT1036 TX5.

Actaeonella browni Sohl and Kollmann, n. sp.

Plate 18, figures 1-8

Diagnosis.-A slender Actaeonella whose greatest whorl diameter lies at about two-thirds the total height.

Description.-Shells of medium to small size. Shell profile convex over lower surfaces, apical tip acute with posterior whorl surface flat to gently convex; maximum diameter at about upper two-thirds point, and equals about one-third of total height. Aperture elongate narrow, incision lacking between parietal lip and very thick columella. Columella bears three plaits of equal strength, area anterior to plaits low, with narrow basal excavation.

Measurements (fig. 38).-Available specimens reach a maximum length of at least $35 \mathrm{~mm}$, but one incomplete specimen (pl. 18, fig. 5) indicates that some individuals may have been as long as $50 \mathrm{~mm}$ and almost $20 \mathrm{~mm}$ wide.

Discussion. -This species is represented by abundant silicified specimens from the type locality. None of them, however, possesses a complete aperture. The available specimens show a minimum variation in shape and, similarly, only a very weak change in proportions during growth. Early growth stages show a

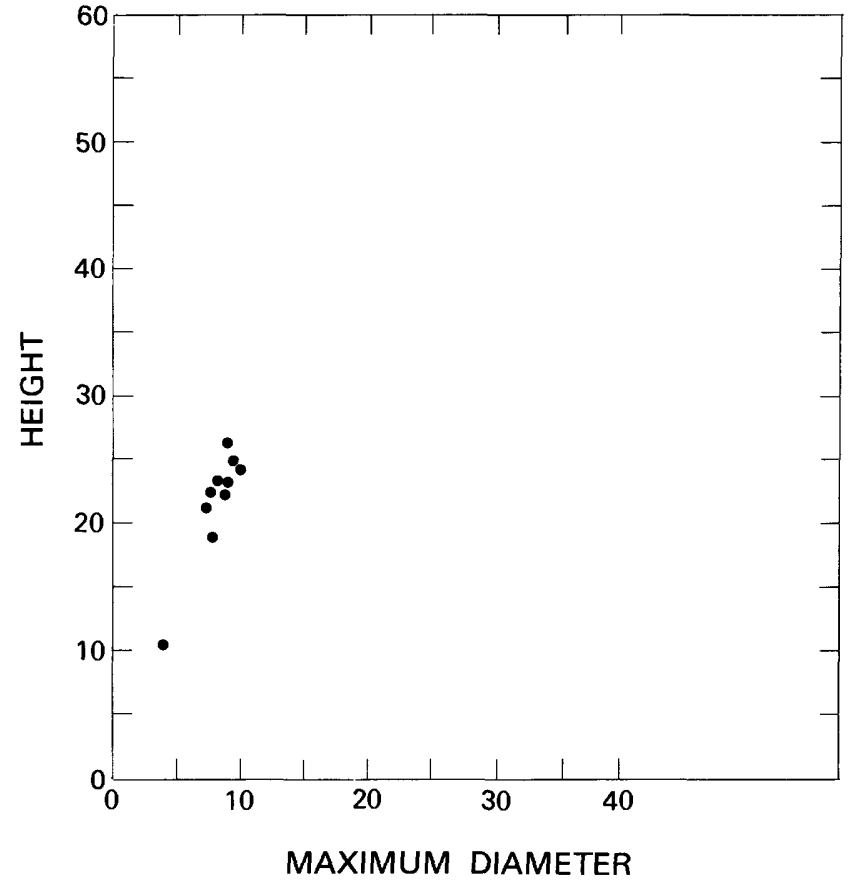

FIGURE 38.-Scatter diagram comparing height with width among selected specimens of Actaeonella browni Sohl and Kollmann, n. sp.

slight tendency toward greater obesity than do later stages, but the amount is hardly noticeable.

Actaeonella browni is morphologically very similar to both A. sublaevis Briart and Cornet and A. delgadoi (pl. 18). All possess a noticeably proportionally thick and well-developed columella. A. browni differs from $A$. delgadoi in its proportionally more slender shell that has a less convex whorl profile and a maximum diameter that is higher on the whorl. Compared with A. sublaevis from the Albian to Cenomanian of Belgium and Austria, $A$. browni differs in having a zone of maximum diameter higher on the whorl and in having flat to slightly convex whorl sides above this zone to the apex rather than having a concave profile in the early stages of growth as in that species.

The species is named in honor of the collector of the material, Barnum Brown.

Occurrence.-Guatemala: Peten area, at locality 160. Age.-Late Albian (or, less likely, early Cenomanian). Types.-Holotype, USNM 306131; paratypes, USNM 306132-306137.

$$
\begin{aligned}
& \text { Actaeonella borneensis Nuttall and Leong } \\
& \text { Plate 19, figures 16-21; plate 20, figure } 11
\end{aligned}
$$

1959. Actaeonella cf. A. laevis d'Orbigny. Chubb. Am. Assoc. Petroleum Geologists Bull, v. 43, p. 752 .

1972. Acteonella borneensis Nuttall and Leong, Malaysia Geol. Survey Geol. Papers, v. 1, p. 3, pl. 1, figs. A-E. 
Diagnosis.-An Actaeonella of accentuated elongate droplike outline.

Description.-Medium-sized shells of very elongate droplike outline, maximum diameter at about onethird total shell height. Body whorl convex in profile to about midwhorl; posterior slope straight to slightly convex, terminating in acute apical tip. Whorls are very narrow internally. Columella with three plaits, posteriormost one most prominent.

Measurements (fig. 39).-The type specimens reach a maximum length of about $110 \mathrm{~mm}$ and a maximum diameter of about $40 \mathrm{~mm}$.

Discussion.-In most regards, Actaeonella borneensis is similar to A. teaensis Sohl and Kollmann; however, in section, the maximum diameter is at the height of the protoconch or midwhorl rather than below. In addition, at all growth stages of $A$. borneensis, the whorls are slightly convex and nearly cylindrical over the anterior half of the whorl. As in the early growth stage of A. teaensis, the anterior half of the whorl is less cylindrical, expanding rapidly in width from the base to point of greatest diameter. In later growth stages, $A$. teaensis also possesses cylindrical whorls, but the

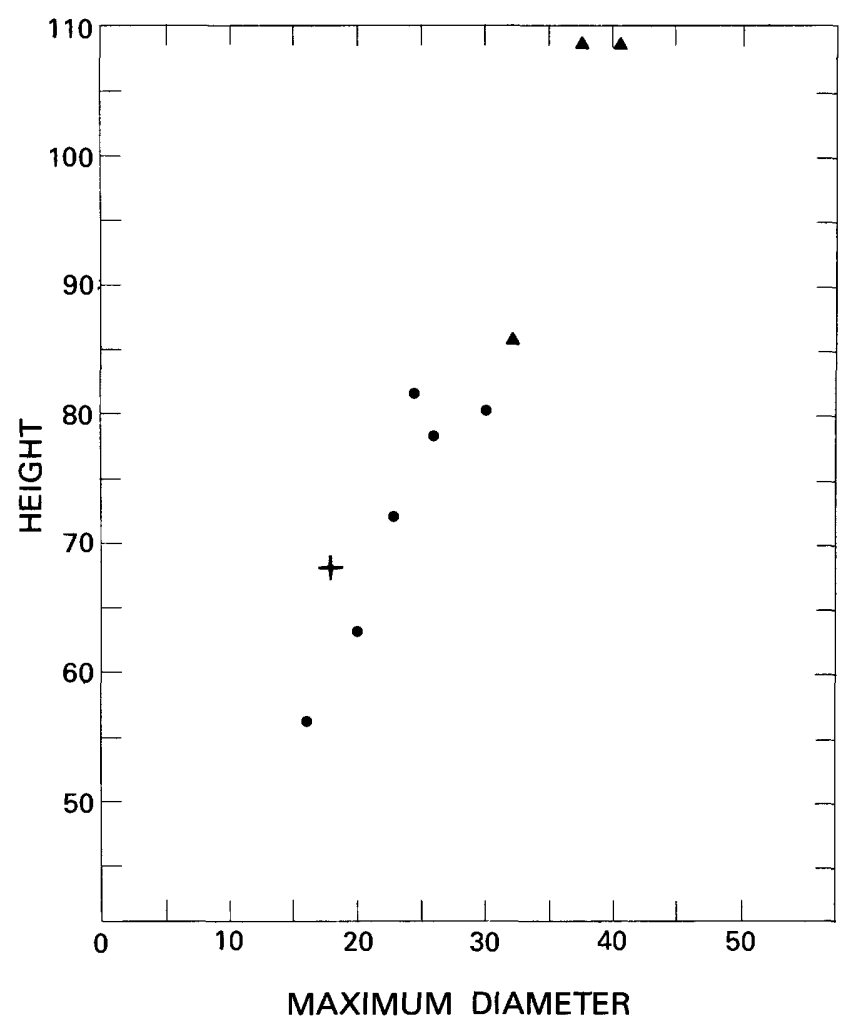

FIGURE 39.-Scatter diagram comparing height with width among selected specimens of Actaeonella borneensis Nuttall and Leong. $\Delta$, Borneo; +, Cuba; •, Mexico. upper whorl slopes are concave rather than generally convex as in A. borneensis.

Occurrence.-Borneo: Sungai Malua, Sabah. Cuba: Santa Clara Province, at locality 130. Mexico: State of Chiapas, upper Rancho Nuevo Beds, at localities 149, 150.

Age.-The type material from Borneo is from an uncertain Cenomanian to Campanian level, according to Nuttall and Leong. In Mexico, Chubb (1959) suggested a Campanian Age, but the associated faunas would probably now be considered early Maastrichtian. In Cuba, the specimens are in an imprecisely dated sequence of Upper Cretaceous rocks. In summary, the best dating suggests a Campanian to Maastrichtian Age for the species.

Types.-Hypotypes, USNM 306156-306161.

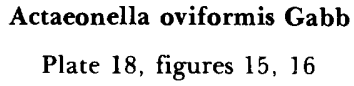

1869. Actaeonella oviformis Gabb, California Geol. Survey, p. 173 , pl. 28 , fig. 58 .

1926. Acteonella oviformis Gabb. Stewart, Acad. Nat. Sci. Philadelphia, Proc., v. 78, p. 432, pl. 21, fig. 13.

Not: 1877. Acteonella oviformis Gabb, Acad. Nat. Sci. Phila delphia Jour., 2d ser., v. 8 , p. 281 , pl. 40 , fig. $6(=T$ (Trochactaeon) or T. (Mexicotrochactaeon)).

Not: 1954. Acteonella oviformis Gabb. Popenoe, California Div. Mines Bull. 170, p. 18, fig. $2(=T$. (Trochac. taeon)).

Not: 1958. Acteonella oviformis Gabb. Anderson, Geol. Soc. America Mem. 71, p. 160 , pl. 29, fig. $6(=T$. (Trochactaeon) packardi).

Discussion.-Only the holotype of this species is known, and it is so poorly preserved that it has been variously interpreted. The specimen is a fragment of a medium-sized Actaeonella with broadly convex sides; it measures $42.5 \mathrm{~mm}$ in height and $21.6 \mathrm{~mm}$ in diameter. The whorls bear distinct orthocline growth lines, and the lower part of the whorls is considerably expanded. There are three columellar plaits, the lower one being very flat. The presence of orthocline growth lines ally the shell to Actaeonella, whereas, as discussed elsewhere herein, the forms described by Anderson (1902, 1958) and Packard $(1916,1922)$ as Actaeonella oviformis belong to the genus Trochactaeon.

The incomplete specimen that Gabb (1871) described from Peru as Actaeonella oviformis is either a T. (Trochactaeon) or a T. (Mexicotrochactaeon).

Occurrence.-Cottonwood Creek, Shasta County, Calif.

Age.-Chico Formation (Cenomanian-Turonian). The stratigraphic position given by Anderson (1958) is not valid, as it refers to another species in the middle Turonian.

Type.-Holotype, ANSP 4323. 
Actaeonella duckettsensis Sohl and Kollman, n. sp.

Plate 19, figures 1-8; plate 20, figures 3, 6

Diagnosis.-An Actaeonella of accentuated slender cylindrical form.

Description.-Small to medium-size subcylindrical shells, maximum diameter 27 to 36 percent of total height; tip obtuse, whorl sides convex; growth lines faint, slightly prosocyrt in lower half of shell, but orthocline above. Aperture long and narrow; columella thin, inductura meets columella outside of aperture at an acute angle, exterior edge of columella elevated or slightly reflected; columella prolonged, and excavated over its full width, grading below into a snoutlike basal lip.

Measurements (fig. 40).-Complete specimens are as much as $47 \mathrm{~mm}$ high and $13 \mathrm{~mm}$ in diameter. The measurements of several incomplete specimens suggest that maximum heights may be slightly greater than $50 \mathrm{~mm}$.

Discussion.-This species may be distinguished by its high subcylindrical shape, its obtuse apical tip, thin columella, and the snoutlike extension of the base (pl. 19, fig. 1). Cut and polished sections (pl. 20, figs. 3 and 6) show that the protoconch is located well above the midpoint of the body whorl. In this regard, Actaeonella duckettsensis is somewhat similar to A. robinsoni. The latter species, however, has a more rounded

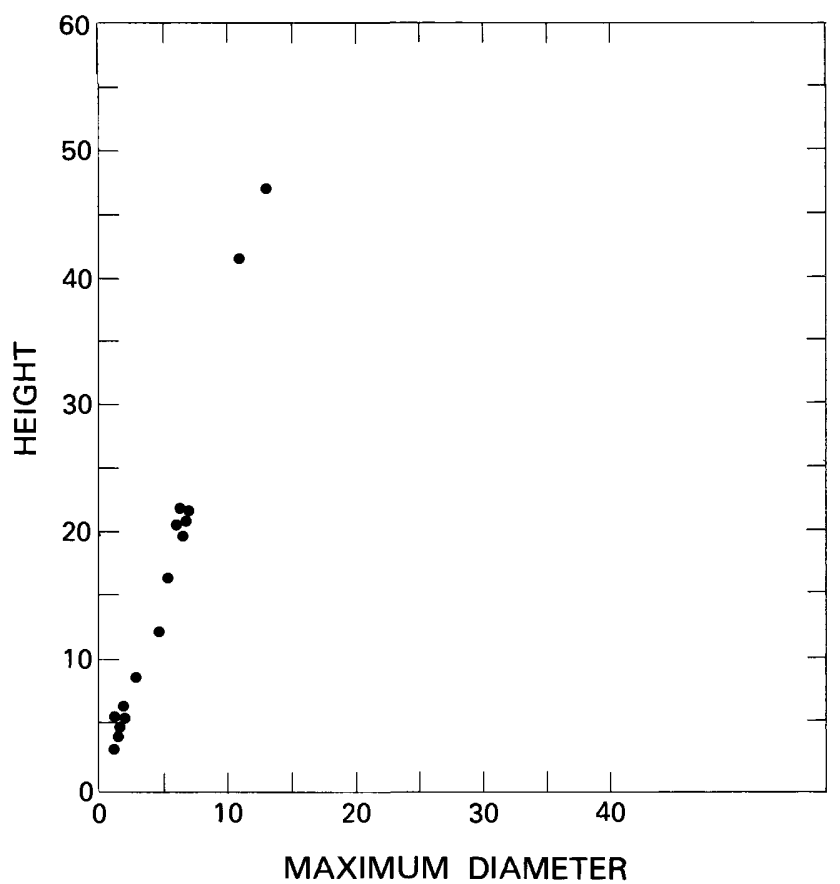

Figure 40.-Scatter diagram comparing height with width among selected specimens of Actaeonella duckettsensis Sohl and Kollmann, n. sp. anterior whorl profile, proportionally broader shell, and concave posterior whorl slope. No other species considered here approaches the relative protoconch position of $A$. duckettsensis.

A rock sample from the Rosario Mine, Comayagua, Honduras, in the collections of the Naturhistorisches Museum, Basel, Switzerland, contains an Actaeonella that probably belongs to this species.

Occurrence.-Jamaica: Green Island inlier, "Barrettia Limestone," at locality 121; Central inlier, Guinea Corn Formation, at localities $61,62,64,75$, and Slippery Rock Formation, at locality 53; Marchmont inlier, "Titanosarcolites Limestone," at localities 97, 106, 107.

Age.-Possibly latest Campanian, definitely early and middle Maastrichtian.

Type.-Holotype, USNM 306150; paratypes, USNM 306145-306149, 306165.

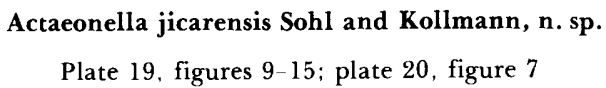

Diagnosis.-Actaeonella with flattened whorl sides between point of maximum diameter and apical tip.

Descriptions.-Small shells; greatest thickness slightly below midwhorl, maximum diameter 31-41 percent of total height, whorl sides flat between area of maximum width and acute apical tip; whorl subcylindrical below point of maximum diameter, slightly convex and rounding down to base. Aperture narrow, but expanding to a trumpetlike exhalant siphon posteriorly and slightly widened anteriorly; columella very short with two weak plaits at aperture that strengthen interiorly; area below plaits short and inclined about $40^{\circ}$ to shell axis within aperture; plaits vanish outside aperture; columella passes into a basal lip that is slightly varicose externally, broadly excavated, and forms an angle of $115^{\circ}$ with shell axis.

Measurements (fig. 41).-Specimens range from 12 to near $30 \mathrm{~mm}$ in height and from 4 to about $11 \mathrm{~mm}$ in diameter; pleural angle ranges from $30^{\circ}$ to $40^{\circ}$.

Discussion.-Large suites of specimens from the type locality in the Sabana Grande Quadrangle of Puerto Rico show the species to possess only minor variation in form. In all specimens, the columellar plications are very weakly developed at the aperture. Occasionally these are so weak that the anteriormost is virtually obliterated, save for a faint swelling. The normally flat profile of the posterior whorl surface occasionally may become faintly concave.

The combination of the presence of only two columellar plications, maximum diameter below midwhorl, and a flat posterior whorl profile serve to distinguish this species from all others in the Western Hemisphere. 


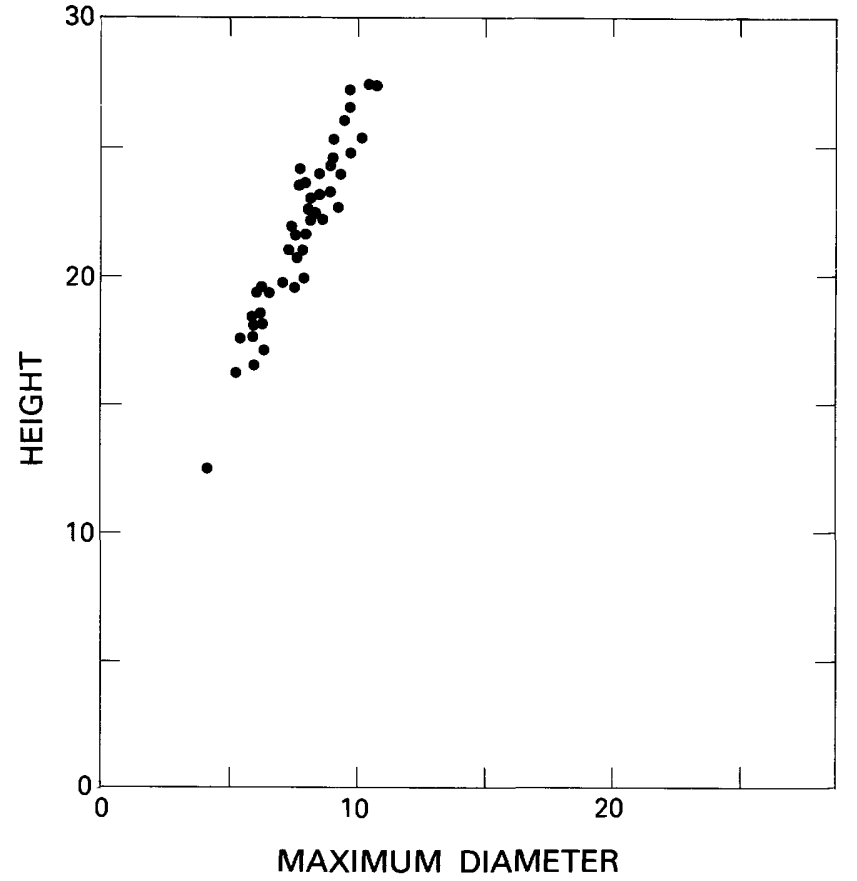

FIGURE 41.-Scatter diagram comparing height with width among selected specimens of Actaeonella jicarensis Sohl and Kollmann, n. sp.

Occurrence-Puerto Rico: Sabana Grande Quadrangle, limestones of the El Rayo Formation, at locality 36 .

Age.-Middle Maastrichtian.

Types.-Holotype, USNM 306154; paratypes USNM 306151-306153, 305155 .

Actaeonella coquiensis Sohl and Kollman n. sp.

Plate 20, figures $1,2,5,8$; plate 21, figures 7-12, 15

Description.-Small to very small shells, maximum diameter at the midshell and constitutes $27-36$ percent of total height. Sides of body whorl strongly concave above midheight, ending in an acute apial tip; on early whorls, diameter diminishes rapidly below middle, giving shell a biconical appearance; in late stages of growth, shell nearly cylindrical below middle but rounding down near base. Aperture narrow, columella with three plaits, lowermost of which is weakest within aperture on early whorls but becomes of equal strength near aperture; columella tapers as it grades into basal lip; upper columellar plait gradually becomes an external thickening of basal lip; lower plaits end at columellar margin.

Measurements (fig. 42).-Specimens reach a maximum height of more than $50 \mathrm{~mm}$, but most commonly are nearer $30 \mathrm{~mm}$. In diameter, the largest specimen

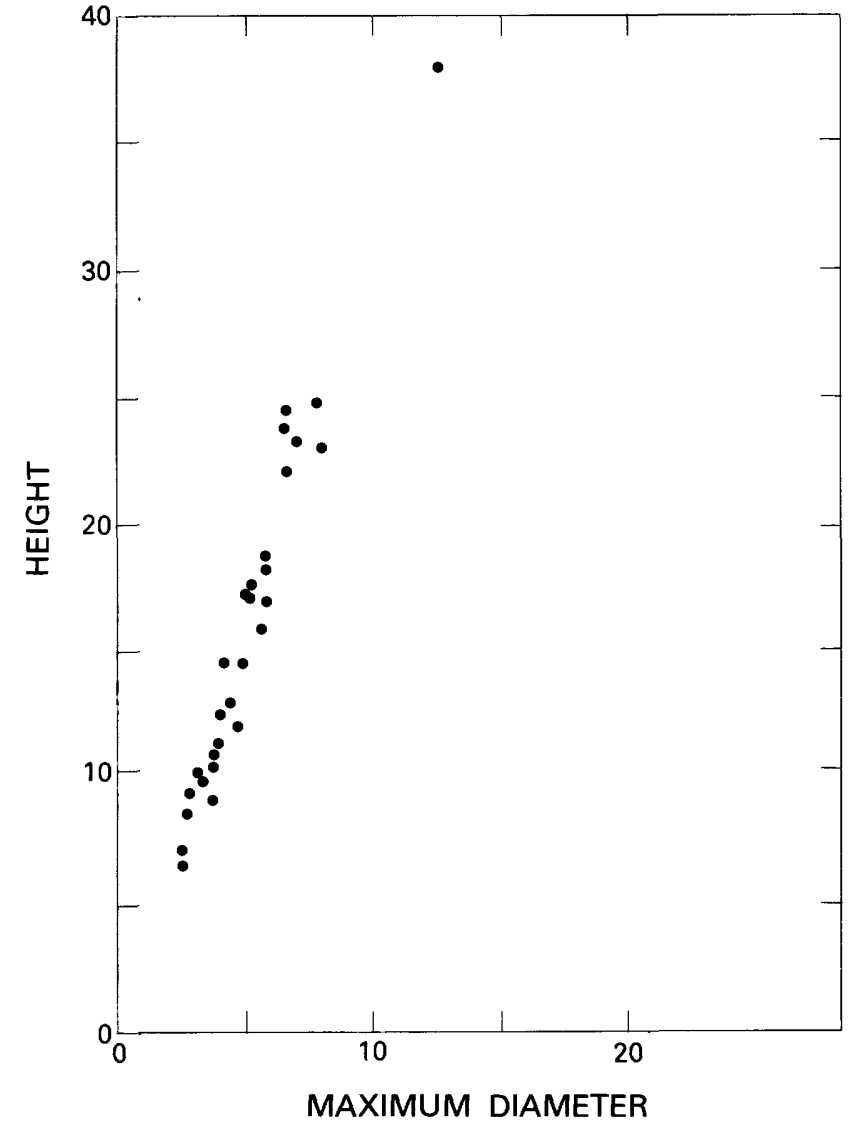

FIGURE 42.-Scatter diagram comparing height with width among selected specimens of Actaeonella coquiensis Sohl and Kollmann, n. sp.

measures $22 \mathrm{~mm}$, but most specimens seldom exceed $12 \mathrm{~mm}$. The pleural angle ranges from $25^{\circ}$ to $35^{\circ}$.

Discussion.-Actaeonella elongata Kollmann (1965) from the Gosau area, Austria, has a similar form and ontogeny. It differs in having stronger columellar plaits and a maximum diameter that lies well below the middle of the shell. Actaeonella laevis (Sowerby) is similar in possessing weak columellar plaits but differs in its regular whorl convexity throughout the total shell length.

Actaeonella coquiensis is abundant at the type locality in shales of the Coamo Formation (of Berryhill and Glover, 1960) at Coqui Hill near Salinas in southcentral Puerto Rico. Here, specimens in a shale unit low in the section are small (20-30 $\mathrm{mm}$ long) but show an average size increase higher in the same section, where some large incomplete specimens are judged to have attained a length of about $60 \mathrm{~mm}$. We tentatively assign to this species, abundant specimens occurring with a diverse molluscan assemblage in shales of the Maldon Limestone at Shaw Castle, Maldon inlier, Jamaica. The small size and variable preservation of 
these specimens leaves some question as to their assignment, but morphologically they seem closest to Actaeonella coquiensis.

Both of the above localities are from approximately the same Maastrichtian stratigraphic level. The specimens herein assigned to this species from immediately above the Barrettia Limestone in the Stapleton Formation of the Sunderland inlier, Jamaica, are from a lower stratigraphic position associated with Torreyites and Barrettia gigas. This association most often suggests an early Maastrichtian Age, but a latest Campanian Age cannot be discounted.

Occurrence.-Puerto Rico: Coamo Formation, Central Aguirre Quadrangle, at localities 16, 18. Jamaica: Maldon inlier, Maldon Limestone, at locality 119; Sunderland inlier, Stapleton Formation, at locality 122; Marchmont inlier, "Titanosarcolites Limestone," at locality 101.

Age.-Latest Campanian(?)-early to middle Maastrichtian.

Types.-Holotype, USNM 306188; paratypes, USNM $306162-306164,306186,306187,306189-306192$, 306204 .

Actaeonella cf. A. coquiensis Sohl and Kollman

Plate 2, figure 6; plate 20 , figure 9 ; plate 21 , figures $13,19-23$

Discussion.-Many medium-sized specimens of Actaeonella from a few localities in both Cuba and Puerto Rico cannot be placed with surety but do show similarity to $A$. coquiensis. In the early stages of growth, the lower part of the whorls increases in width from the base toward the midheight, which lies below the level of the protoconch. In later growth stages the lower part of the shell becomes increasingly cylindrical. The upper or posterior part of the shell has flat or slightly concave sides that slope gradually to the apical tip. The aperture is narrow and elongate with a proportionally long columella that bears three plaits, of which the upper one is the strongest. Below the plaits, the columella is strongly concave. The available specimens have a maximum height of $66 \mathrm{~mm}$ a maximum diameter of $30 \mathrm{~mm}$. The pleural angle ranges from $30^{\circ}$ to $45^{\circ}$

All the larger free specimens are imcomplete, lacking the apical parts of the shell. Thus, it seems prudent to await collection of better preserved material before final assignment is made.

Specimens of Actaeonella coquiensis are similar in showing a parallel ontogenetic change in whorl shape with increased size.

Occurrence.-Puerto Rico: Melones Limestone, Puerto Real Quadrangle, at localities 31, 32. Cuba, Santa Clara Province, at locality 127.

Age.-Middle Maastrichtian in Puerto Rico and of uncertain but presumably the same age in Cuba.

Types.-Hypotypes, USNM 305600, 306167, 306193-306198.

Actaeonella marchmontensis Sohl and Kollmann, n. sp. Plate 21, figures 1-6

Description.-Shell generally small but rarely attaining medium size; whorl sides evenly but only moderately convex, apex obtuse; maximum diameter 34-52 percent of total height. Aperture very narrow, with a short columella of medium thickness; uppermost columellar plait stronger than two lower ones; middle plait closer to lower than to upper one; uppermost plait borders columella at junction with parietal region and disappears when edge bends sharply down towards base; middle plait grades into basal lip; area below middle plait becomes progressively more in. clined relative to axis within aperture; lowermost plait diminishing in strength, disappearing before columella grades into excavated basal lip and not visible at aperture.

Measurements (fig. 43).-Our specimens range from 3.2 to $38 \mathrm{~mm}$ in height and have a maximum diameter of 1.6 to $4.3 \mathrm{~mm}$. The pleural angle ranges from $40^{\circ}$ to $64^{\circ}$.

Discussion.-This species differs from Actaeonella briggsi by its flattened area below the middle colu-

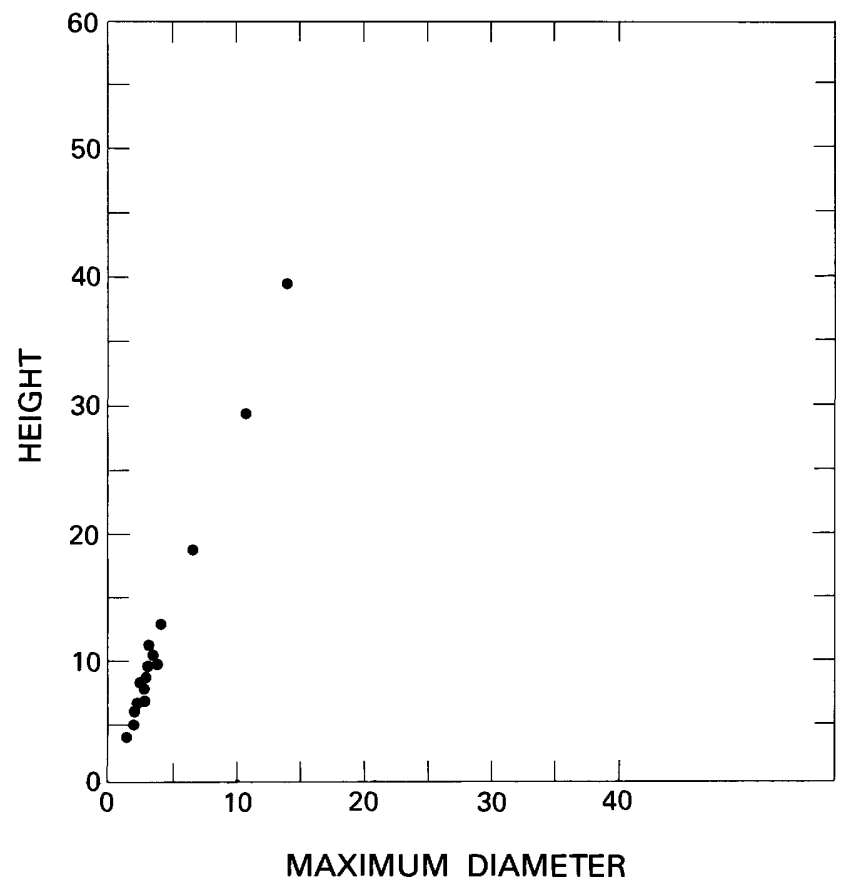

FIGURE 43.-Scatter diagram comparing height with width among selected specimens of Actaeonella marchmontensis Sohl and Kollmann, n. sp. 
mellar plait, the less rounded whorl sides, and more slender form.

Actaeonella laevis (Sowerby) has an obtuse tip like Actaeonella marchmontensis, but it attains a larger size. The maximum diameter of $A$. laevis is less than 30 percent of the total height. The columella is short, like that of $A$. marchmontensis, but the area below the middle plait is not flattened within the aperture.

Actaeonella marchmontensis is the most common species in the Titanosarcolites-bearing limestones and shales of Jamaica. It occures within the same sections as $A$. duckettsensis but may be differentiated by its less cylindrical form.

Occurrence.-Jamaica: Marchmont inlier, from Titanoscarcolites-bearing shales and limestone, at localities 92, 93, 97, 98, 100, 103, 106; Maldon inlier; Maldon Limestone, at locality 119; and Woodland Shale, at locality 116. Central inlier, Guinea Corn Formation, at localities $57,60,64,77,79,80$.

Age.-Middle Maastrichtian.

Types.-Holotype, ISNM 130671; paratypes, 130668$130670,130672,130673$.

Actaeonella briggsi Sohl and Kollmann n. sp.

Plate 20, figure 4; plate 21, figures 14, 16-18.

Description.-Shell small, with strongly but evenly curving convex sides, maximum diameter at middle of shell and constituting 43 to 49 percent of total height; apex broadly obtuse. Aperture proportionally broad. Columella long and thick, an inverted cone in form; columellar plaits decrease in strength anteriorly; margin of columella with parietal lip strongly downturned towards basal lip. Basal lip inclined, not thickened, and narrowly excavated.

Measurements (fig. 44).-The available specimens range from 14.5 to $31.0 \mathrm{~mm}$ in height and have a maximum diameter of 6.8 to $13.4 \mathrm{~mm}$. The plural angle ranges from $43^{\circ}$ to $50^{\circ}$.

Discussion.-Actaeonella briggsi differs from Actaeonella marchmontensis by its proportionally greater maximum diameter and by the shape of the columella, which is a broadly inverted cone. In contrast, the columella of $A$. marchmontensis is strongly inclined toward the axis below the middle columellar plait. Compared with other proportionally obese species of Actaeonella of the region, $A$. briggsi lacks the extreme concave upper whorl face of $A$. robinsoni and $A$. cubensis and has a proportionally longer columella.

The species is named for Reginald P. Briggs, in recognition of his many contributions to the understanding of the geology of Puerto Rico.

Occurrence.-Puerto Rico: Barranquitas Quadrangle, Pozas Formation, Reves Member, at localities 4, 5, 6; San German Quadrangle, El Rayo Formation, at locali-

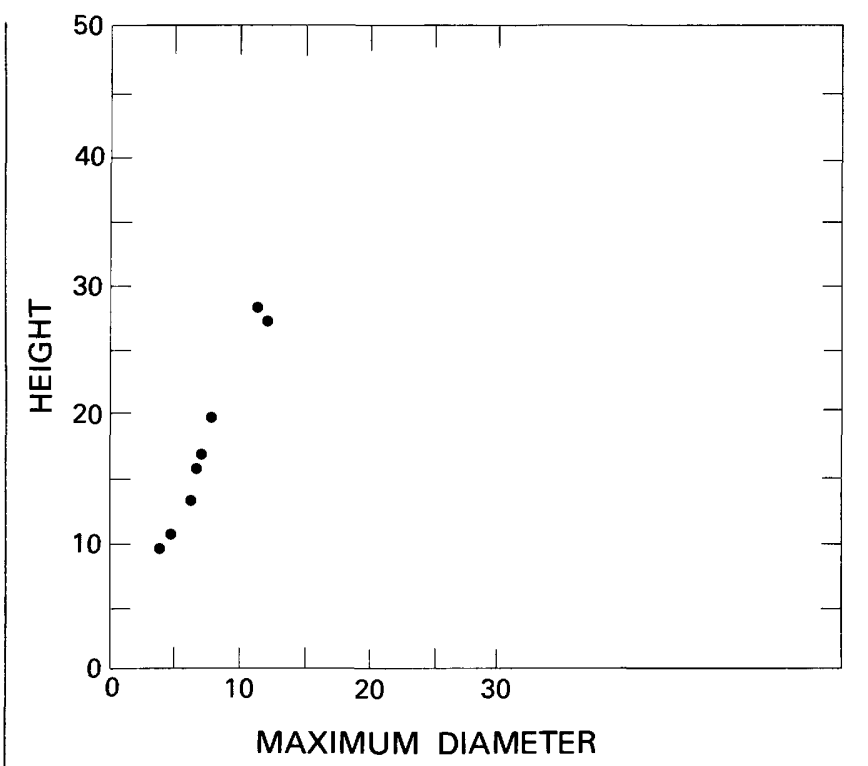

FIGURE 44.-Scatter diagram comparing height with width among selected specimens of Actaeonella briggsi Sohl and Kollmann, n. sp.

ties 48, 49a, 51, 51a, and Cotui Limestone (top), at locality 47.

Age.-Early to middle Maastrichtian.

Types.-Holotype, USNM 306201; paratypes, USNM 306166, 306199, 306200.

Actaeonella cubensis Sohl and Kollmann n. sp.

Plate 17, figure 2; plate 23, figures 2-5, 7, 8

1955. Actaeonella (Volvulina) aff. laevis (Sowerby). Lewis and Straczek, U.S. Geol. Survey Bull. 975-D, p. 194..

Diagnosis.-An Actaeonella with strongly concave upper whorl profile, inflated whorls below midheight, and two columellar plications.

Description.-Shell of medium size, strongly inflated on anterior half with strongly concave sides above midheight. Aperture broad, lacks a constriction between columella and parietal region. Columella short, bears two sharp plaits; columella bends strongly downwards out-side of aperture; lower part of columella and adaxial part of basal lip slightly reflected. In longitudinal section, first four whorls form a high spiral shell that is gradually concealed by fourth whorl; succeeding whorls are completely involute.

Measurements (fig. 45).-The pleural angle of available specimens ranges from $33^{\circ}$ to $40^{\circ}$.

Discussion.-The presence of only two columellar plications distinguishes this species from all others in the Western Hemisphere except Actaeonella robinsoni. A. cubensis differs from that species especially in its more concave upper-whorl profile and in the great in- 


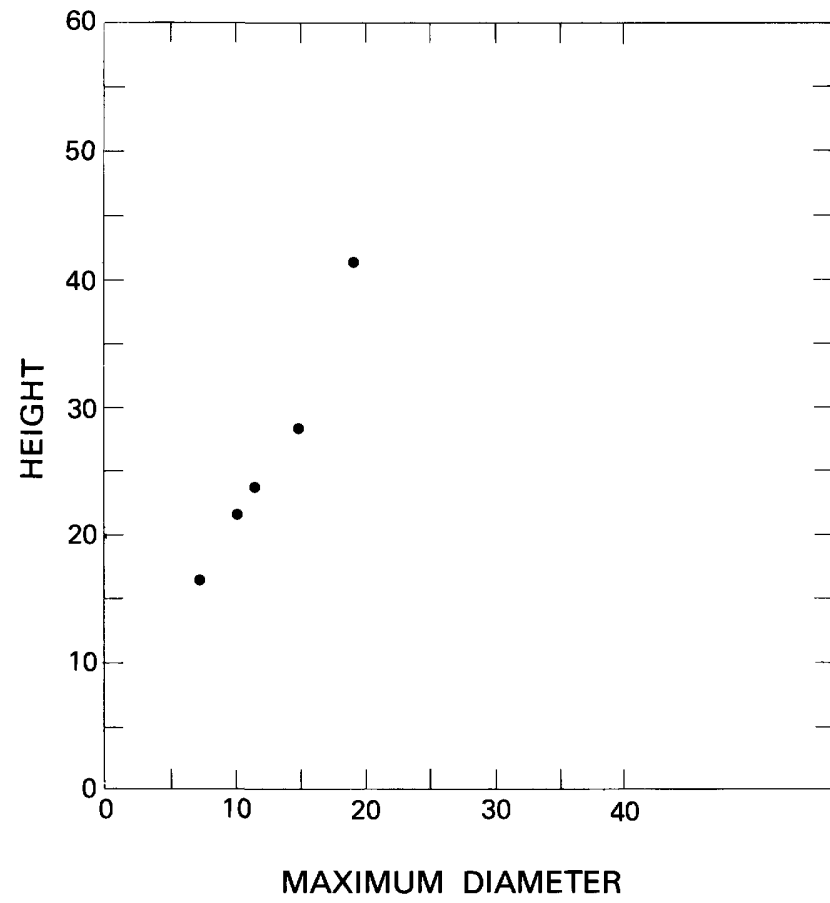

IFIGURE 45.-Scatter diagram comparing height with width among selected specimens of Actaeonella cubensis Sohl and Kollmann, n. sp.

flation of the whorls below midheight.

Occurrence-Cuba: Oriente Province, Habana (?) Formation (Lewis and Straczek 1955, p. 194), at locality 125.

Age.-Judging by the associated fauna, Lewis and Straczek's assignment of the species to the late Senonian seems feasible. The specimens probably come from a late Campanian or Maastrichtian level.

Types.-Holotype, USNM 306183; paratypes: 306127, 306182, 306184-306186.

\section{Actaeonella robinsoni Sohl and Kollmann, n. sp.}

Plate 17, figures $1,4,5$; plate 22 , figures $1,2,5$

?1906. Actaeonella (S.S.) aff. grossouvrei Cossmann. Böse, Mexico lnst. Geol. Bol. 24, p. 91.

Diagnosis.-An Actaeonella with a convex upper whorl profile and columella bearing only two columellar plications.

Description.-Shells of medium size; maximum diameter at middle of shell and constitutes 40 percent of total height, whorls broadly convex over anterior part but sides concave in profile on upper part of shell, ending in acute tip. Aperture moderately wide. Columella proportionally long and bears strong columellar plaits; upper plait vanishes at aperture, lower plait passes into varicose basal lip, which is only partly known; labral edge of columella indistinct.
Measurements.-The holotype is $58.6 \mathrm{~mm}$ high, has a maximum diameter of $24.8 \mathrm{~mm}$, and a pleural angle of $38^{\circ}$. Paratypes range from 30 to $66 \mathrm{~mm}$ in height, have a maximum diameter of 13 to $32 \mathrm{~mm}$, and a pleural angle ranging from $30^{\circ}$ to $38^{\circ}$.

Discussion.-This species is rare but possesses sufficiently distinctive characters to merit formal naming. Described species of Actaeonella that have an accentuated concave upper whorl profile are considerably less common than those having convex profiles. Among these, $A$. robinsoni is especially distinguished by having only two columellar plications rather than three. In this latter character, $A$. robinsoni is similar to $A$. cubensis Kollman and Sohl. A. cubensis differs notably in its midwhorl obesity and especially in the accentuated concavity of the upper whorl.

The species is named for Dr. E. Robinson of the University of the West Indies, Kingston, Jamaica, in recognition of his contributions to understanding of the geology of Jamaica.

Occurrence.-Jamaica: Central inlier, Guinea Corn Formation, at localities 69, 70; Mexico, San Luis Potosi, Cardenas Formation, at locality 158.

Age.-Maastrichtian.

Types.-Holotype, USNM 306176; paratypes, USNM 306124-306126, 306174, 306175.

Actaeonella n. sp. A.

Plate 17, figure 3; plate 22, figs. 3, 4; plate 23, figures 1,6

Discussion.-The specimen figured on plate 22 , figure 4, probably represents the largest known Actaeonella. All available specimens are incompletely preserved, but we estimate that some must have exceeded $180 \mathrm{~mm}$ in length and about $95 \mathrm{~mm}$ in maximum diameter. In cut section the shells are seen to be strongly inflated, the maximum diameter being below midheight. The upper whorl profile is slightly concave to flat, and the basal profile is rounded. The aperture is widest in the anterior part; the columella is thick and bears three plaits that decrease in strength anteriorly. The lower quarter of the whorl bears a strong palatal ridge. In this feature, this species differs from all Actaeonella known from the Western Hemisphere.

This actaeonellid shows several features comparable with those of described species from other regions. For example, the strong palatal ridge in the lower part of the whorl is similar to that of $A$. crassa (Dujardin, 1835), which is of wide occurrence in the Upper Cretaceous rocks of Europe and eastern Asia (Kollmann, 1965; Hacobjan, 1976). The Puerto Rican form here discussed, however, is proportionally much more obese. A. inflata Petho (1906), described from the upper Campanian-Maastrichtian of Fruska Gora in northern Serbia, possesses a similarly obese shell, but the profile 
of the upper part of the shell is convex rather than concave to flat.

The few available specimens and their poor state of preservation precludes formal naming of this species.

Occurrence.-Puerto Rico: Orocovis Quadrangle, Pozas Formation, Rio Bauta Member, at locality 26; Coamo Quadrangle, Maravillas Formation, at locality 19.

Age.-Campanian-early Maastrichtian.

Types.-Hypotypes, USNM 306128, 306177, 306180, 306181.

Actaeonella sp. B.

Plate 22, figure 7

Discussion.-Several incomplete specimens of an indeterminate Actaeonella have been found in collections preserved in erratic cobbles of sideritic ironstone concretions in glacial till from Martha's Vineyard, Mass. Although these specimens cannot be assigned to a given species, they are of special importance, as they represent the northernmost unquestioned occurrence of the genus in eastern North America (fig. 11).

The shells have a blunted apex and slightly convex whorl sides. The small but best preserved specimen (pl. 22, fig. 7) measures $9 \mathrm{~mm}$ in height and has a maximum diameter of $3.8 \mathrm{~mm}$. Other apertural features are obscured because of state of preservation.

Occurrence.-Massachusetts: Martha's Vineyard, at locality 131 .

Age.-Late Cenomanian.

Types.-Hypotype, USNM 360179.

\section{Actaeonella sp. C. \\ Plate 2, figure 5}

Discussion.-The collections of the U.S. Geological Survey contain two collections of fossils from along the Yukon River in Alaska that have yielded three specimens of an Actaeonella. According to D.L. Jones (oral commun. 1981), the assemblages are from the lower part of the Upper Cretaceous (Cenomanian-Turonian). Both collections are small and were made during the early exploratory phase of geologic work in Alaska (1899 and 1902). The many subsequent collections made from the Cretaceous of Alaska have failed to recover additional specimens.

These two occurrences are remarkable because they are the northernmost records of the family in the world. During Cenomanian time, Actaeonella had its greatest northward expansion in range (see fig. 7); It has been found in both eastern Siberia and Massachusetts, but both of these occurrences are many degrees of paleolatitude south of Alaska. This anomalously farnorth occurrence may be associated with a "suspect terrane" as viewed by Coney and others (1980). That is, these specimens may be part of an autocthonous province transported to its present position from a more southerly source and subsequently accreted to the Cordilleran margin.

Occurrence.-Alaska: Yukon River, at localities 169, 170.

$$
\text { Types.-Hypotype, USNM } 306203 .
$$

Actaeonella spp.

Actaeonella also occurs at other Cretaceous localities in Jamaica and Puerto Rico. These specimens, however, are either poorly preserved, fragmental, or known only in cut sections; proper specific placement cannot be made. The specimens are in rocks ranging in age from Albian to Maastrichtian and no doubt represent several species, some of which may be new.

Species of Albian Age occur in calcareous silty mudstones in both the Barrancas Limestone Member of the Magueyes Formation (locality 12, pl. 22, fig. 6) and the Rio Maton Limestone Member of the Robles Formation in central Puerto Rico. In both these units. Actaeonella is rare but is found in association with assemblages dominated by rudist bivalves and nerineid gastropods.

Undetermined Actaeonella is widespread in Campanian to Maastrichtian-Age rocks. In Puerto Rico, these fossils have been collected in the Botijas Limestone Member of the Pozas Formation in the Barranquitas Quadrangle (localities 10 and 11); the Sabana Hoyos Limestone Member of the Maravillas Formation of the Orocovis Quadrangle (localities 29, 30); the Maravillas Formation of the Rio Descalabrado (localities 34, 35) and Coamo (locality 21) Quadrangles; and the El Rayo Formation (locality 49) and Cotui Limestone (locality 38 ) of the San German Quadrangle. In Jamaica, undetermined Actaeonella occurs in the Inoceramus Shales of the Anns Great River inlier (locality 123) in the Guinea Corn Formation of the Central inlier (localities 62,64 and 76) and in the Titanosarcolites bearing limestones of the Jerusalem Mountain inlier (localities 110, 112-115).

Types.-Hypotype, USNM 360178.

\section{CATALOGUE OF ACTAEONELLID SPECIES}

The following listing of species assigned to the Family Actaeonellidae provides the basis for the construction of the distribution maps (figs. 5-13) and diversity graphs (figs. 3,4$)$. The listing reflects views of the authors on overall generic and subgeneric assignments. We have not investigated all species in equal detail because of lack of adequate comparative material. Thus, the listing should not be viewed as a final synonymy. For example, no decision has been reached on the validity of the exceptionally large number of 
species that Pchelintsev and other authors have proposed from the Cenomanian, Turonian, and Coniacian of the Transcaucasus. In this regard, the catalogue is more a guide to the existing literature and a status report than a final expression of our views on validity of all species-level taxa.

A separate listing following this section includes those genera and species that Kollmann and Sohl (1980) and other authors have removed from the Actaeonellidae; most of these taxa are now assigned to the nerineacean family Itieriidae.

Trochactaeon (Neocylindrites) abbreviatus (Conrad)

1852. Nerinea abbreviata Conrad

1867. N. abbreviata Fraas

1891. N. abbreviata Whitfield

1900. Trochactaeon abbreviatus Böhm

1927. Actaeonella (Trochactaeon) abbreviata Blanckenhorn

1939. Actaeonella abbreviata Delpey (part)

Age.-Aptian.

Occurrence.-Lebanon; Syria; Israel.

Trochactaeon (Neocylindrites) absalonis (Fraas)

1867. Phasianella absalonis Fraas

1867. P. absalonis Fraas

1878. Actaeonella absalonis Fraas

1890. A. absalonis Blanckenhorn

1900. Trochactaeon absalonis Böhm

1976. Palaeotrochactaeon absalonis Hacobjan

Age-Cenomanian-Turonian.

Occurrence.-Lebanon; Syria; Israel; USSR (Armenian SSR).

Trochactaeon (Trochactaeon) acuminatus (Frič)

1897. Actaeonella acuminata Frič

Age.-Coniacian.

Occurrence.-Czechoslovakia.

The following species has been assigned to $T$. (T.) acuminata but is here assigned elsewhere:

1934. Actaeonella acuminata Andert (see T. (T.) beyrichi Drescher)

Actaeonella (Trochactaeon) acutissima Böse, 1906 (see Trochactaeon (Mexicotrochactaeon) coniformis Böse)

Trochactaeon agbulakhensis G. A. Aliev, 1959, 1963 (see Trochactaeon (T.) intermedius Choffat)

Actaeonella agricolai Vidal

1921. Actaeonella agricolai Vidal

1949. A. agricolai Bataller

Age.-Maastrichtian (Garumnien).

Occurrence.-Spain (Province of Lerida).

Trochactaeon (Trochactaeon) alibeglyensis Pchelintsev

1954. Trochactaeon alibeglyensis Pchelintsev

Age.-Cenomanian.

Occurrence.-USSR (Transcaucasus).
Trochactaeon (Neocylindrites) angustatus Pchelintsev

1953. Trochactaeon angustatus Pchelintsev

1967. Actaeonella (Trochactaeon) angustata Rahman

1974. Palaeotrochactaeon angustatus Hacobjan

1976. P. angustatus Hacobjan

Age.-Cenomanian

Occurrence.-USSR (Armenian SSR); Austria (Tyrol).

Trochactaeon (Trochactaeon) armenicus Pchelintsev

1954. Trochactaeon armenicus Pchelintsev

Age.-Late Turonian.

Occurrence.-USSR (Armenian SSR).

Trochactaeon (Trochactaeon) arnaudi Cossmann

1896. Trochactaeon arnaudi Cossmann

1972. Mesotrochactaeon arnaudi Hacobjan

1974. M. arnaudi Hacobjan

1976. M. arnaudi Hacobjan

Age.-Turonian.

Occurrence.-France (Charente); USSR (Armenian SSR).

Trochactaeon (Trochactaeon) artsachensis (Hacobjan)

1976. Mesotrochactaeon artsachensis Hacobjan

Age.-Turonian.

Occurrence.-USSR (Armenian SSR).

Trochactaeon (Trochactaeon) atschadjurensis Pchelintsev, 1954

1954. Trochactaeon atschadjurensis Pchelintsev

Age.-Coniacian.

Occurrence._USSR (Transcaucasus).

Trochactaeon (Trochactaeon) asiaticus Pchelintsev, 1953

(see Trochactaeon (Trochactaeon) schirabadensis (Djalilov))

Trochactaeon (Trochactaeon) babkovi Djalilov

1972. Trochactaeon babkovi Djalilov

1977. T. babkovi Djalilov

Age.-Campanian.

Occurrence.-USSR (Tadzahkistan depression).

Actaeonella baconica Benkö-Czabalay

1962. Actaeonella baconica Benkö-Czabalay

Age.-Albian.

Occurrence.-Hungary (Bakony Mountains).

Trochactaeon (Neocylindrites) baconicus Benkö-Czabalay

1962. Trochactaeon baconicus Benkö-Czabalay

1976. Paleotrochactaeon baconicus Hacobjan

Age.-Albian.

Occurrence.-Hungary (Bakony Mountains).

Trochactaeon (Neocylindrites) barremicus Sayn

1932. Trochactaeon barremicus Sayn

1932. T. barremicus var. cylindrica Sayn

1932. T. barremicus var. mumiaeformis Sayn 
Age.-Barremian.

Occurrence-France (Drôme).

Trochactaeon (Neocylindrites) baylei Leymerie of Daguin

1927. Actaeonella (Trochactaeon) baylei Leymerie of Daguin

Age.-Senonian.

Occurrence.-Morocco.

Trochactaeon (Neocylindrites) belgicus Cossmann

1865. Actaeonella conica Briart and Cornet

1896. Trochactaeon belgica Cossmann (name substituted for Actaeonella conica Briart and Cornet, 1865) (not Zekeli. 1852, and part of Actaeonella briarti Geinitz, 1874)

1939. Actaeonella (Trochactaeon) conica Marlière

Age.-Late Albian.

Occurrence.-Belgium.

Trochactaeon (Trochactaeon) beyrichi Drescher

1863. Actaeonella beyrichi Drescher

1910. A. beyrichi Weinzettl

1934. A. beyrichi Andert

1934. A. acuminata Andert

1963. Purpuractaeon beyrichi Hacobjan

Age.-Coniacian

Occurrence-Czechoslovakia; German Democratic Republic; Poland.

Trochactaeon (Trochactaeon) biconicus Pchelintsev

1954. Trochactaeon biconicus Pchelintsev

Age.-Early riuronian.

Occurrence.-USSR (Armenian SSR).

Actaeonella borneensis Nuttall and Leong

1959. Actaeonella cf. laevis d'Orbigny, Chubb

1972. A. borneensis Nuttall and Leong

Age.-Late Campanian-Maastrichtian.

Occurrences.-Borneo; Cuba (Santa Clara Province); Mexico (Chiapas).

Trochactaeon (Neocylindrites) boutillieri Cossmann

1896. Trochactaeon boutillieri Cossmann

1900. T. boutillieri Cossmann

1916. T. boutillieri Cossmann

1932. T. boutillieri Sayn

Age.-Barremian.

Occurrence.-France (Bouches du Rhône, Gard, Drôme).

Actaeonella (Trochactaeon) brevis Böse, 1906

(see Trochactaeon (Mexicotrochactaeon) coniformis (Böse)

Trochactaeon (Neocylindrites) briarti Geinitz

1874. Trochactaeon briarti Geinitz

1905. Actaeonella conica Deninger

1910. A. briarti Weinzettl

1974. P. briarti Hacobjan

1976. P. briarti Hacobjan
Age.-Late Cenomanian.

Occurrence.-Belgium; Czechoslovakia; Saxony; USSR (Armenian SSR).

Actaeonella browni Sohl and Kollmann

Age.-Late Albian or Cenomanian.

Occurrence.-Guatemala.

Trochactaeon (Mexicotrochactaeon) burckhardti Böse

1923. Actaeonella (Trochactaeon) burckhardti Böse

1923. A. (T.) burckhardti var. obliquecostata Böse

1923. A. (T.) gigantea Sowerby, sp. n. var. mexicana Böse

1923. A. (T.) humboldti Böse

1923. A. (T.) quadriplicata Böse

1930. Actaeonella luciano Maury

1930. A. pompei Maury

1930. A. cf. silvai Maury

1976. Neotrochactaeon burckhardti Hacobjan (not pl. 15, figs. 3-5, 7-10, and pl. 14, figs. 12, 13)

1976. Trochactaeon obliqueplicatus Hacobjan (included is T. impressus Pchelintsev, 1954, as a synonym

Age.-Coniacian, Maastrichtian.

Occurrence-Mexico (State of Guerrero); Brazil; Jamaica.

The following species has been assigned to $T$. (M.) burckhardti but should be placed elsewhere:

1950. Actaeonella (Trochactaeon) burckhardti Böse? Maldonado-Koerdell.

Actaeonella briggsi Sohl and Kollmann

Age.-Maastrichtian.

Occurrence.-Puerto Rico.

Actaeonella caucasica caucasica Zekeli

1852. Actaeonella caucasica Zekel

1928a.A. caucasica Pchelintsev

1953. A. caucasica Pchelintsev

?1958. A. caucasica Aliev

1965. A. caucasica caucasica Kollmann

1972. A. (Pchelincevella) caucasica Djalilov

1974. Actaeonella caucasica Hacobjan

1976. A. caucasica Hacobjan

1977. A. (Pchelincevella) caucasica Djaliloy

Age.-Cenomanian.

Occurrence.-USSR (Transcaucasus and questionably Elenstop Mountains, Shankhorsk region).

\section{Actaeonella caucasica grossouvrei Cossmann}

1896. Actaeonella grossouvrei Cossmann

1901. A. grossouvrei Choffat

1920. A. grossouvrei Roman and Mazeran

1965. A. grossouvrei Roman and Mazeran

1972. A. (Pchelincevella) grossouvrei Djalilov

1977. A. (P.) grossouvrei Djalilov

[Assigned to Actaeonella uchauxensis Cossmann by Hacobjan, 1974 and 1976]

Age.-Turonian.

Occurrence.-France (Uchaux); Portugal.

The following species have been assigned to Actaeo. 
nella caucasica grossouvrei but should be placed elsewhere:

1906. Actaeonella aff. A. grossouvrei Böse

1972. A. grossouvrei Collignon (see $A$. delgadoi)

\section{Actaeonella caucasica styriaca Kollmann}

1892. Actaeonella (Volvulina) laevis Futterer

1895. A. (V.) laevis Böhm

1964. A. (Actaeonella) caucasica Kollmann

1962. Actaeonella caucasica styriaca Benkö-Czabalay

?1964. Actaeonella caucasica styriaca Benkö-Czabalay

1965. A. caucasica styriaca Kollmann

?1966. A. caucasica Lupu

1972. A. (Pchelincevella) styriaca Djalilov

1977. A. (Pchelincevella) styriaca Djalilov

[Assigned to Actaeonella crassa by Hacobjan, 1974 and 1976]

Age.-Late Coniacian-Santonian.

Occurrence.-Austria; Italy (Venetian Alps); Hungary; Romania.

\section{Actaeonella caucasica schiosensis Böhm}

1895. Actaeonella (Volvulina) schiosensis Böhm

1900. A. (V.) schiosensis Fittipaldi

1965. Actaeonella caucasica schiosensis Kollmann

1972. A. (Pchelincevella) schiosensis Djalilov

1974. Actaeonella schiosensis Hacobjan

1976. A. schiosensis Hacobjan

1977. A. (Pchelincevella) schiosensis Djalilov

Age.-Late Cenomanian-early Turonian.

Occurrence.-Italy (Venetian Alps; Campobasso).

\section{Actaeonella caucasica zouparriensis Choffat}

1901. Actaeonella zouparriensis Choffat

1965. A. caucasica zouparriensis Kollmann

1972. A. (Pchelincevella) zouparriensis Djalilov

1977. A. (P.) zouparriensis Djalilov

Age.-Turonian.

Occurence.-Portugal.

Trochactaeon (Trochactaeon) caucasicus Pchlintsev

1953. Trochactaeon caucasicus Pchelintsev

Age.-Cenomanian.

Occurrence.-USSR (Transcaucasus).

Trochactaeon (Trochactaeon) choffati Pchelintsev

1954. Trochactaeon choffati Pchelintsev

Age.-Coniacian.

Occurrence.-USSR (Transcaucasus).

Trochactaeon (Trochactaeon) collignoni (Darteville and Bréhion)

1956. Actaeonella (Trochactaeon) collignoni Darteville and Brébion 1974. Trochactaeon collignoni Hacobjan

Age.-Early Cenomanian-late Turonian.

Occurrence.-Gabon; USSR (Armenian SSR).

Trochactaeon (Trochactaeon) communis Pchelintsev

1954. Trochactaeon communis Pchelintsev

Age.-Coniacian.
Occurrence.-USSR (Armenian SSR).

\section{Trochactaeon (Trochactaeon) conicus Münster}

1844. Tornatella conica Münster in Goldfuss

1850. Actaeonella conica d'Orbigny

1852. A conica Zekeli

1959. A. (Trochactaeon) conica Pokorný

1962. Trochactaeon (Trochactaeon) conicus Benkö-Czabalay

1966. Actaeonella (Trochactaeon) conica Marincas

1967. Trochactaeon (Trochactaeon) conicus Kollman

1974. Spiractaeon conicus Hacobjan

1974. Spiractaeon conica Hacobjan

1976. S. conica Hacobjan

Age.-Santonian.

Occurrence-Austria; Romania; Hungary; USSR (Transcaucasus, Central Asia).

The following species have been assigned to $T$. (T.) conicus (Münster) but should be placed elsewhere:

1865. Actaeonella conica Stoliczka (see T. (T.) goldfussi (d'Orbigny))

1865. A. Conica Briart and Cornet (see T. (T.) belgicus Cossmann)

1881. Tornata conica Quenstedt (see T. (T.) goldfussi)

1892. Actaeonella conica Futterer (see $T$. (Neocylindrites) sp.)

1939. (Trochactaeon) conica Marlière (see $T$. (T.) belgicus Cossmann)

1957. A. conica Pejović

1965. A. (Trochactaeon) conica Lupu

Trochactaeon (Trochactaeon) conicus Hacobjan, not Münster

1963. Purpuractaeon conicus Hacobjan

1972. P. conicus Hacobjan

Age.-Coniacian.

Occurrence.-USSR (Devi River, Armenian SSR).

Trochactaeon (Mexicotrochactaeon) coniformis coniformis (Böse)

1906. Actaeonella (Trochactaeon) coniformis Böse

1906. A. (T.) acutissima Böse

1906. A. (T.) occidentalis Böse

1906. A. (T.) inconstans Böse

1906. A. (T.) irregularis Böse

1906. A. (T.) brevis Böse

1906. A. (T.) planilateralis Böse

1906. A. (T.) potosiana Böse

1906. A. (T.) variabilis Böse

1968. Actaeonella coniformis Myers

1972. Mexicotrochactaeon acutissima Hacobjan

1972. $M$. irregularis Hacobjan

1972. M. planilateralis Hacobjan

1972. M. potosiana Hacobjan

1972. $M$. variablilis Hacobjan

1976. Spiractaeon brevis Hacobjan

Age.-Maastrichtian.

Occurrence.-Mexico (Cardenasa area, State of San Luis Potosi).

All following assigned herein to $T$. (Neocylindrites) punctatus Maldonado-Koerdell, 1950:

1950. A. (Trochactaeon) coniformis Maldonado-Koerdell

1950. A. (Trochactaeon) acutissima punctata Maldonado-Koerdell

1950. A. cf. A. (T.) occidentalis Maldonado-Koerdell (p. 215, fig. 17.) 
1950. A. cf. (T.) inconstans Maldonado-Koerdell

1950. A. (T.) planilateralis Maldonado-Koerdell

Trochactaeon (Trochactaeon) conoideus (Matheron)

1842. Mitra conoidea Matheron

1902. Actaeonella (Trochactaeon) conoidea Cossmann

\section{Age.-Santonian.}

Occurrence.-France (Bouches-du-Rhône).

Actaeonella coquiensis Sohl and Kollman

Age.-Maastrichtian

Occurrence.-Puerto Rico; Jamaica

Trochactaeon (Neocylindrites) cordeiroi (Choffat)

1888. Cylindrites delgadoi Choffat, in Choffat and Loriol

1888. C. delgadoi Choffat

1956. Actaeonella (Trochactaeon) cordeiroi Darteville and Brébion

1976. Paleotrochactaeon cordeiroi Hacobjan

Age.-Albian-early Cenomanian.

Occurrence.-Angola; Bas-Congo; USSR (Armenian SSR).

Trochactaeon (Trochactaeon) cossmanni Choffat (see T. (T.) giganteus subglobosus (Münster))

Trochactaeon (Trochactaeon) cossmanni var. obesus Hojnos (see T. (T.) giganteus subglobosus Münster)

Actaeonella crassa (Dujardin)

1835. Volvaria crassa Dujardin

1842. Actaeonella crassa d'Orbigny

1863. A. crassa Schafhäutl

1865. Volvulina crassa Stoliczka

1953. Actaeonella crassa Pchelintsev

1954. A. gracilis Pchelintsev

1954. A. crassa Pchelintsev

?1956. A. cf.A. crassa Darteville and Brébion

?1964. A. crassa Djalilev (assigned to $A$. longa by Hacobjan, 1976)

1965. $A$. aff. $A$. crassa Kollmann

1972. A. (Pchelincevella) crassa in Djalilov

1972. A. (P.) gracilis Djalilov

1974. Acteonella crassa Hacobjan

1976. A. crassa Hacobjan

1977. A. (P.) crassa Djalilov

1977. A. (P.) gracilis Djalilov

Age-Cenomanian-Coniacian.

Occurrence.-France; Austria; USSR (Transcaucasus, Darvaza, Turkmen, Sikhote-Alin), questionably, Gabon, west Africa.

The species listed below has been assigned to $A$. crassa but should be placed elsewhere:

1916. Actaeonella crassa Douvillé (Campanian; Tibet)

\section{Trochactaeon? cretaceus (Müller)}

1851. Cassidaria cretacea Müller

1859. Globiconcha maxima Müller

1888. Actaeonella cretacea Holzapfel (pl. 7, figs. 11, 15, 16, assigned to Sevenella by Hacobjan, 1974)

1974. Purpuractaeon cretaceus Hacobjan
Age.-Coniacian or Santonian.

Occurrence.-West Germany (Aachen).

Trochactaeon (Neocylindrites) crisminensis Choffat

1901. Trochactaeon crisminensis Choffat

1953. T. subangustatus Pchelintsev

1954. T. subangustatus Pchelintsev

1966. Actaeonella (T.) subangustatus Lupu

1972. Paleotrochactaeon crisminensis Hacobjan

1974. P. crisminensis Hacobjan

1976. P. crisminensis Hacobjan

(Hacobjan, 1976, also included Trochactaeon cylindraceus Stoliczka)

Age.-Late Albian-Cenomanian.

Occurrence.-Portugal; USSR (Armenian SSR, Central Asia).

Actaeonella cubensis Sohl and Kollman

Age.-Maastrichtian.

Occurrence.-Cuba.

Trochactaeon (Neocylindrites) cumminsi (Stanton)

1947. Trochactaeon cumminsi Stanton

1947. T. parvus Stanton

1955. Actaeonella (Trochactaeon) parvus Allison

Age.-Albian.

Occurrence.-Texas; Mexico (Baja California).

Trochactaeon (Trochactaeon) cylindraceus (Stoliczka)

1868. Actaeonella cylindracea Stoliczka

1976. Paleotrochactaeon cylindraceus Hacobjan (excludes pl. 14, fig. 10 $[=P$. crisiminensis Choffat of Hacobjan])

Age.-Otatoor Group Cenomanian(?)-Turonian.

Occurrence.-Southern India; Gabon; Angola?; USSR

(Armenian SSR).

The species listed below have been assigned to $T$. (T.) cylindraceus (Stoliczka) but should be placed elsewhere:

1884. Trochactaeon cylindraceus Whiteaves (affinities unknown)

1956. Actaeonella (Trochactaeon) cylindracea Darteville and Brébion

Trochactaeon (Trochactaeon) cylindricus Pchelintsev

1928. Trochactaeon cylindricus Pchelintsev

1953. T. cylindricus Pchelintsev

1954.. T. cylindricus Pchelintsev

1976. Mesotrochactaeon cylindricus Hacobjan

\section{Age.-Cenomanian.}

Occurrence.-USSR (Armenian SSR).

Trochactaeon (Trochactaeon) cycloideus Pchelintsev

1954. Trochactaeon cycloideus Pchelintsev

Age.-Late Senonian.

Occurrence-UUSSR (Armenian SSR).

Actaeonella decorata Hacobjan

1976. Acteonella decorata Hacobjan

Age.-Late Cenomanian.

Occurrence.-USSR (Armenian SSR). 
Trochactaeon? damesi Futterer

1892. Cylindrites damesi (Futterer)

Age.-Early Senonian.

Occurrence.-Italy (Venetian Alps).

Trochactaeon (Trochactaeon) darwasensis Djalilov

1964. Trochactaeon darwasensis Djalilov

1977. Spiractaeon darwasensis Djalilov

(Hacobjan 1976, assigned pl. 24, fig. 3, of Djalilov, 1964 to Spiractaeon obtusus)

Age.-Late Coniacian.

Occurrence.-USSR (Darvaza, Turkmen SSR).

Trochactaeon? delgadoi (Choffat)

(see Trochactaeon (Neocylindrites) cordeiroi (Choffat))

1888. Cylindrites delgadoi Choffat, in Choffat and Loriol, 1888

1956. Cylindrites(?) delgadoi Darteville and Brébion

Age.-Albian.

Occurrence.-Angola.

Actaeonella delgadoi Choffat

1901. Actaeonella delgadoi Choffat

1916. A. gracilis Douvillé

1955. A. gracilis Mahmoud

1963. A. gracilis var. Maqharensis Abbass

1972. A. grossouvrei Collignon

1972. A. (Pchelincevella) delgadoi Djalilov

1977. A. (P.) delgadoi Djalilov

Age.-Albian-Cenomanian.

Occurrence.-Portugal; Egypt (Sinai); Madagascar; USA (Texas)

Trochactaeon dilatatus Pchelintsev, 1954

(see $T$. (T.) giganteus subglobosus (Münster))

Trochactaeon (Trochactaeon) dolioliformis Pchelintsev

1953. Trochactaeon dolioliformis Pechelintsev

Age.-Cenomanian.

Occurrence.-USSR (Transcaucasus).

Trochactaeon (Trochactaeon) dubertreti (Delpey)

1939. Actaeonella dubertreti Delpey

Age.-Late Cenomanian.

Occurrence.-Lebanon.

Actaeonella duckettsensis Sohl and Kollmann

Age.-Maastrichtian.

Occurrence.-Jamaica.

Trochactaeon (Trochactaeon) ellipsoides (Fittipaldi) (see Trochactaeon (T.) matensis (Fittipaldi))

1900. Actaeonella ellipsoides Fittipaldi

1953. Trochactaeon subotusus Pchelintsev

1953. T. matensis Pchelintsev (part) (pl. 48 , fig. $16=T$. (T.) toursensis Hacobjan))

1953. T. regularis Pchelintsev (part) (fide, Hacobjan, 1974, not. pl. 50, figs. 8,10 )
Age.-Cenomanian-Turonian.

Occurrence.-Italy (Venetian Alps); USSR (Armenian SSR).

Trochactaeon (Trochactaeon) ellipticus Zekeli

(see Trochactaeon conicus Münster)

1852. Actaeonella elliptica Zekeli

1954. Trochactaeon ellipticus Pchelintsev

1976. Spiractaeon ellipticus Hacobjan

\section{Actaeonella elongata Kollman}

1852. Actaeonella laevis Zekeli (part)

1965. A. elongata Kollmann

\section{Age.-Late Santonian.}

Occurrence.-Austria.

Trochactaeon (Trochactaeon) excelsus Pchelintsev

1954. Trochactaeon excelsus Pchelintsev

1974. Neotrochactaeon excelsus Hacobjan

Age.-Coniacian.

Occurrence.-USSR (Armenian SSR).

Actaeonella? faba (Kner)

1849. Volvaria faba Kner

1972. Actaeonella (Pchelincevella) faba Djalilov

1977. A. (Pchelincevella) faba Djalilov (possibly belongs to Ellipsoscapha)

Age.-Maastrichtian.

Occurrence.-USSR (Lvov).

Trochactaeon (Trochactaeon) frazierensis (Anderson)

1958. Actaeonella frazierensis Anderson

1958. A. rustica Anderson

1979 (1976). A. frazierensis Jones, Sliter, and Popenoe

Age.-Turonian.

Occurrence.-USA (northern California).

Actaeonella fusiformis Coquand

1865. Actaeonella fusiformis Coquand

1887. A. fusiformis Mallada

1939. A. fusiformis Delpey

1949. A. fusiformis Bataller

?1955. A. fusiformis Allison

\section{Age.-Aptian.}

Occurrence.-Spain (Teruel); Lebanon.

Trochactaeon (Trochactaeon) galloprovincialis (Cossmann)

1842. Actaeonella gigantea d'Orbigny

1850. A. gigantea d'Orbigny

1895. A. (Trochactaeon) gigantea Cossmann

1897. Trochactaeon giganteus var. galloprovincialis Cossmann

1901. T. giganteus Choffat

1901. T. giganteus var. glandiformis Choffat

1967. T. (Trochactaeon) aff. galloprovincialis Kollmann (assigned to Neotrochactaeon giganteus (Sowerby) by Hacobjan, 1976)

Age.-Turonian(?)-Santonian.

Occurrence.-Austria; Portugal; France (LeBeausset). 
Trochactaeon (Trochactaeon) giganteus giganteus (Sowerby)

1832. Tornatella gigantea Sowerby

1957. Actaeonella renauxiana Pejovic

1959. A. (Trochactaeon) gigantea gigantea Pokorny

1959. A. (T.) gigantea subglobosa Pokorny

1966. $A$. (T.) gigantea Todirita-Mihailescu

1966. A. (T.) gigantea ventricosa Todirita-Mihailescu

1966. $A$. (T.) gigantea ventricosa Marincas

1967. Trochactaeon (T.) giganteus Kollmann

1967. T. (T.) giganteus giganteus Kollmann

1972. Neotrochactaeon gigantea Hacobjan

1974. N. giganteus Hacobjan

1976. N. giganteus Hacobjan

Age.-Santonian-early Campanian.

Occurrence.-Austria; Yugoslavia; Hungary; Portugal; Romania; Greece; ?USSR (Transcaucasus-Cenomanian).

The species listed below have been assigned to $T$. (T.) giganteus giganteus (Sowerby) but should be placed elsewhere:

1842. Actaeonella gigantea d'Orbigny (= Trochactaeon (T.) galloprovincialis Cossmann)

1844. A. gigantea Münster (= Trochactaeon (T.) kuehni Kollmann 1967, to Neotrochactaeon ventricosus (Hojnos) by Hacobjan, 1976)

1844. Tornatella subglobosa (Münster) (= Trochactaeon $(T$.) giganteus subglobosus)

1850. Actaeonella subglobosa d'Orbigny

1851. Actaeon giganteus Müller

1852. Actaeonella gigantea (Sowerby) Zekeli (= Trochactaeon subglo . bosus (Münster) fide Kollmann, 1967)

1852. A. lamarcki Zekeli (pl. 6, fig. $2=T$. (T.) giganteus subglobosus (Münster), fide Kollmann, 1967)

1884. Tornatella giganteus (Sowerby) Quenstedt (fig. $128=$ Trochactaeon goldfussi (d'Orbigny))

1888. Actaeonella gigantea Holzapfel

1896. Trochactaeon giganteus Cossmann

1897. T. giganteus var. galloprovincialis Cossmann (elevated to specific rank by Kollmann 1967; included in $T$. (T.) giganteus by Hacobjan, 1976)

1901. T. cossmanni Choffat ( $=T$. (T.) giganteus subglobosus (Münster))

1901. T. giganteus Choffat $(=$ Trochactaeon (T.) galloprovincialis Cossmann)

1901. Trochactaeon giganteus var. intermedia Choffat $(=$ Trochactaeon (Trochactaeon) intermedius (Choffat))

1901. $T$. giganteus var. glandiformis Choffat $(=T$. (T.) galloprovincialis Cossmann, fide Kollmann, 1967)

1906. Actaeonella (Trochactaeon) aff. gigantea Böse (= Neotrochac taeon fide Hacobjan, 1972; see Trochcactaeon (Mexicotrochactaeon) burckhardti)

1910. Actaeonella gigantea Weinzettl

1911. A. gigantea Frič (= Neocylindrites sp.)

1921. A. (Trochactaeon) gigantea ventricosa Hojnos

1921. Trochactaeon transylvanicus Hojnos $(=T$. (T.) giganteus sub. globosus Münster)

1923. Actaeonella (Trochactaeon) gigantea var. mexicana Böse

1929. Actaeonella gigantea Steinmann

1950. A. (Trochactaeon) gigantea globosa Maldonado-Koerdell

1951. Actaeonella gigantea Pašic ( $=$ Mesotrochactaeon subglobosa fide Hacobjan, 1976)

1957. A. giganteus var. glandiformis Pejovic (= Trochactaeon (Trochactaeon) lamarcki lamarcki (Sowerby))
1959. Trochactaeon giganteus (Sowerby), Mitzopoulos (= Neotrochactaeon ventricosa (Hojnos) fide Hacobjan, 1976)

1959. Actaeonella (Trochactaeon) gigantea ventricosa Pokorny ( $=$ Trochactaeon (Trochactaeon) giganteus subglobosa (Münster))

Trochactaeon (Trochactaeon) giganteus subglobosus (Münster)

1844. Tornatella subglobosa Münster

1850. Actaeonella subglobosa d'Orbigny

1852. A. gigantea Zekeli

1852. A. lamarcki Zekeli (part)

1853. A. gigantea Reuss (part)

1896. Trochactaeon cossmanni Choffat

1901. T. cossmanni Choffat

1921. T, giganteus var. ventricosus Hojnos

1921. T. cossmanni var. obesus Hojnos

1921. $T$., typus II Hojnos

1921. T. transyivanicus Hojnos

1951. Actaeonella gigantea Pas̃ić

1954. Trochactaeon cossmanni Pchelintsev

1954. T. dilatatus Pchelintsev

1959. Actaeonella (Trochactaeon) gigantea subglobosa Pokorný

1962. Trochactaeon (Trochactaeon) giganteus subglobosus Benkö-Czabalay

1967. T. (T.) giganteus subglobosus Kollmann

1976. Neotrochactaeon ventricosa (Hojnos) Hacobjan

Age.-Santonian-early Campanian(?).

Occurrence.-Austria; Yugoslavia; Hungary; Romania; Portugal; USSR (Transcaucasus).

Trochactaeon (Trochactaeon) ghazirensis (Delpey)

1939. Actaeonella ghazirensis Delpey

1952. A. ghazirensis Termier and Termier

Age.-Cenomanian-Turonian.

Occurrence.-Lebanon.

Trochactaeon (Trochactaeon) glandiformis (Zekeli) (see $T$. (T.) sanctaecrucis)

1852. Actaeonella glandiformis Zekeli (figs. $9 \mathrm{a}-9 \mathrm{~b}=$ Trochactaeon col lignoni Darteville and Brebion, fide Hacobjan, 1974)

1901. Trochactaeon glandiformis Choffat (pl. 1, fig. 20, not pl. 1, fig. 21 = Neotrochactaeon choffati (Pechelintsev) fide Hacobjan, 1976)

1954. Trochactaeon subglandiformis Pchelintsev

1954. T. subovatus Pchelintsev

1974. Neotrochactaeon glandiformis Hacobjan

1976. N. glandiformis Hacobjan

\section{Age-Late Turonian-Santonian.}

Occurrence.-Portugal; Austria; USSR (Transcaucasus).

Trochactaeon (Trochactaeon) goldfussi (d'Orbigny)

1844. Tornatella lamarckii Münster

1850. Actaeonella goldfussi d'Orbigny

1850. A. toucasiana d'Orbigny

1852. A. lamarcki Zekeli (pl. 6, fig. 4, 5, not fig. 2, $3=$ Trochactaeon giganteus fide Kollmann, 1967)

1853. A. goldfussi Reuss

1884. Tornata conica Quenstedt

1884. T. gigantea Quenstedt

1884. T. lamarcki Quenstedt

1959. Actaeonella (Trochactaeon) goldfussi Pokorný

1962. Trochactaeon (Trochactaeon) goldfussi Benkö-Czabalay

1966. Actaeonella (Trochactaeon) goldfussi Marincas 
1966. A. (T.) goldfussi Todirita-Mihailescu

1967. Trochactaeon (Trochactaeon) goldfussi Kollmann

Age.-Late Turonian-Santonian.

Occurrence.-France; Austria; Romania; Hungary.

Trochactaeon (Neocylindrites) gosaviensis Kollman

1967. Trochactaeon (Neocylindrites) gosaviensis Kollmann

\section{Age..-Coniacian-Santonian.}

Occurrence.-Austria.

Actaeonella gracilis Douville, 1916

(see $A$. delgadoi Choffat)

Actaeonella gracilis Pchelintsev, 1954

(see $A$. crassa Dujardin)

Actaeonella grossouvrei Cossmann, 1896

(see $A$. caucasica grossouvrei Cossmann)

Trochactaeon (Trochactaeon) gracilis Pchelintsev

1954. Trochactaeon gracilis Pchelintsev

1976. Spiractaeon obtusus Hacobjan

Age.-Late Coniacian-Santonian.

Occurrence.-USSR (Transcaucasus).

Trochactaeon (Neocylindrites) gradatus Kollman

1967. Trochactaeon (Neocylindrites) gradatus Kollmann

Age.-Late Coniacian-Santonian.

Occurrence-Austria.

Trochactaeon (Mexicotrochactaeon) granthamensis Sohl and Kollmann Age.-Middle Maastrichtian.

Occurrence.-Jamaica.

Trochactaeon (Trochactaeon) gulistanensis Pchelintsev

1954. Trochactaeon gulistanensis Pchelinstev

Age.-Cenomanian.

Occurrence.-USSR (Transcaucasus).

Actaeonella (Trochactaeon) humboldti Böse, I923

(see Trochactaeon (Mexicotrochactaeon) burckhardti (Böse))

Trochactaeon (Trochactaeon) humei (Greco)

1916. Actaeonella (Trochactaeon) humei Greco

Age.-Turonian.

Occurrence.-Egypt.

Trochactaeon (Trochactaeon) idjevanensis (Hacobjan)

1976. Paleotrochactaeon idjevanensis Hacobjan

Age.-Late Cenomanian.

Occurrence.-USSR (Armenian SSR).

Trochactaeon impressus Pchelintsev, 1954

(see $T$. obliqueplicatus Böse of Hacobjan, 1976)

Actaeonella (Trochactaeon) inconstans Böse, 1906

(see Trochactaeon (Mexicotrochactaeon) coniformis (Böse))

Actaeonella inflata Pethö

1906. Actaeonella (Volvulina) inflata Pethö

1982. Ovactaeonella dolium Konovalov and Poyarkova
Age-Maastrichtian.

Occurrence.-Yugoslavia (Fruska-Gora).

Actaeonella (Trochactaeon) irregularis Böse, 1906

(see Trochactaeon (Mexicotrochactaeon) coniformis (Böse))

Trochactaeon insignis Pchelintsev, 1954

(see $T$. pruniformis Hacobjan, 1974)

Actaeonella involuta Coquand

1862. Actaeonella involuta Coquand

1896. A. involuta Cossmann

Age.-Late Santonian.

Occurrence.-France (Lot, Charente); Algeria? (on the basis of an internal mold of questionable affinities).

Actaeonella jicarensis Sohl and Kollmann

Age.-Maastrichtian.

Occurrence.-Puerto Rico.

Trochactaeon (Trochactaeon) kuehni Kollman

1967. Trochactaeon (Trochactaeon) kuehni Kollmann

Age.-Santonian.

Occurrence.-Austria.

Actaeonella laevis laevis (Sowerby)

1832. Volvaria laevis Sowerby

1845. Actaeonella laevis Reuss

1852. A. laevis Zekeli (part)

1853. A. laevis Reuss

1860. A. obliquecostata Stoliczka

1865. Volvulina laevis Stoliczka

1888. Actaeonella laevis Holzapfel

1895. A. terebellum Cossmann

1896. A. laevis Cossmann

?1902. A. laevis Choffat

1959. A. laevis Pokorný

1965. A. laevis laevis Kollmann

1976. A. laevis Hacobjan

The species listed below have been assigned to Actaeonella laevis laevis but should be placed elsewhere:

1842. Actaeonella laevis d'Orbigny (assigned to $A$. caucasica grossouvrei Cossmann by Kollmann, 1965, to A. uchauxensis Cossmann by Hacobjan, 1976)

1852. A. laevis Bronn (assigned to $A$. caucasica grossouvrei by Kollmann, 1965 , to $A$. uchauxensis by Hacobjan, 1976)

1890. A. laevis Blanckenhorn (assigned to $A$. styriaca by Kollmann, 1965)

1892. A. (Volvulina) laevis Futterer

1895. A. (Volvulina) laevis Böhm (assigned to A. caucasica styriaca by Kollmann, 1965)

1895. Actaeonella laevis Cossmann (assigned to A. uchauxensis by Hacobjan, 1976

1899. A. (Volvulina) laevis d'Alesandri

1910. Actaeonella laevis Weinzettl

1911. A. laevis Frič

1939. A. laevis Delpey

1956. A. laevis Darteville and Brébion

Age.-Coniacian(?)-Santonian.

Occurrence.-Austria (Gosau); ?Portugal; West Germany (Aachen region); USSR (Armenian SSR). 
Trochactaeon (Trochactaeon) lamarcki lamarcki (Sowerby)

1832. Tornatella lamarcki Sowerby

1850. Actaeonella lamarcki d'Orbigny

1850. A. voluta d'Orbigny

1852. A. voluta Zekeli

1853. A. lamarcki Reuss

1867. A. syriaca Fraas

1867. A. salomonis Fraas

1884. A. voluta Quenstedt

1903. A. salomonis Dacqué

1921. A. salomonis Dacqué

1921. A. voluta Dacqué

1957. A. giganteus var. glandiformis Pejović

1959. A. (Trochactaeon) lamarcki Pokorný

1963. A. (T.) salomonis Abbass

1964. A. (T.) lamarcki Kollmann

1966. A. (T.) lamarcki Marincas

1966. A. (T.) lamarcki Todirita-Mihailescu

1967. Trochactaeon (Trochactaeon) lamarcki lamarcki Kollmann

1974. Spiractaeon lamarcki Hacobjan

1976. S. lamarcki Hacobjan

Age.-Turonian-Santonian.

Occurrence.-Austria; Romania; Yugoslavia; Greece; Syria; Egypt; USSR (Armenian SSR).

The species listed below have been assigned to Trochactaeon (Trochactaeon) lamarcki lamarcki but should be placed elsewhere:

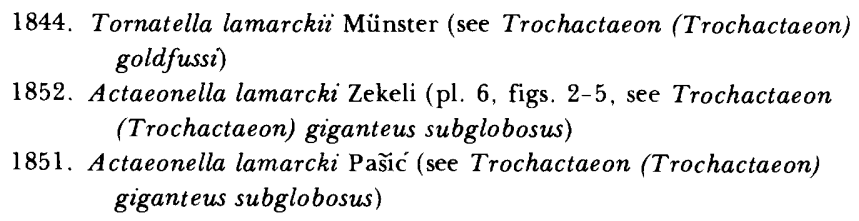

Trochactaeon (Trochactaeon) lamarcki brandenbergensis Kollmann

1967. Trochactaeon (Trochactaeon) lamarcki brandenbergensis Kollmann

Age.-Late Coniacian.

Occurrence.-Austria.

Trochactaeon (Sevanella) laticostata (Hacobjan)

1972. Sevanella laticostata Hacobjan

1974. S. laticostata Hacobjan

1976. S. laticostata Hacobjan

Age.-Late Coniacian.

Occurrence.-USSR (Armenian SSR).

Trochactaeon (Trochactaeon) latus Pchelintsev

1954. Trochactaeon latus Pchelintsev

Age.-Early Cenomanian.

Occurrence.-USSR (Armenian SSR).

Actaeonella longa Hacobjan

1954. Actaeonella crassa Pchelintsev

1976. A. longa Hacobjan

Age.-Late Coniacian.

Occurrence.-USSR (Armenian SSR; Turkmen SSR. (SW. Darvaz)).
Trochactaeon longisulcus Hacobjan

1912. Actaeonella (Trochactaeon) salomonis Pervinquière 1965. Actaeonella? salomonis Homaoui and Raab 1976. Mesotrochactaeon longisulcus Hacobjan

Age.-Turonian.

Occurrence.-USSR (Armenian SSR).

Actaeonella lucianoi Maury, 1930

(see Trochactaeon (Mexicotrochactaeon) burckhardti (Böse))

Trochactaeon (Trochactaeon) mammilatus (Hacobjan)

1976. Purpuractaeon mammilatus Hacobjan

Age.-Late Coniacian.

Occurrence.-USSR (Armenian SSR).

Actaeonella marchmontensis Kollmann and Sohl

Age.-Maastrichtian.

Occurrence.-Jamaica.

Trochactaeon (Trochactaeon) matensis (Fittipaldi)

1900. Actaeonella matensis Fittipaldi

1900. A. ellipsoides Fittipaldi

1953. Trochactaeon matensis Pchelintsev

1966. Actaeonella (Trochactaeon) matensis Lupu (Hacobjan, 1974 removed pl. 5, figs. 9, 11, and pl. 51, figs. 9, 10, 12 of Trochactaeon matensis Pchelintsev to Mesotrochactaeon ellipsoides (Fittipaldi))

Age-Cenomanian-Turonian.

Occurrence.-Italy (Campobasso); USSR (Transcaucasus); Romania.

Trochactaeon (Mexicotrochactaeon) melonensis Sohl and Kollmann

Age.-Maastrichtian.

Occurrence.-Puerto Rico.

Trochactaeon (Neocylindrites) minutus Stoliczka

1868. Trochactaeon minutus Stoliczka

Age.-Campanian-Maastrichtian.

Occurrence.-Southern India.

Trochactaeon (Trochactaeon) mirabilis Pchelintsev

1954. Trochactaeon mirabilis Pchelintsev

Age.-Early Senonian.

Occurrence.-USSR (Armenian SSR).

Trochactaeon (Mexicotrochactaeon) nelsoni Sohl and Kollmann

Age.-Middle to late Maastrichtian.

Occurrence.-Puerto Rico.

Trochactaeon (Trochactaeon) obesus Pchelintsev

1954. Trochactaeon obesus Pchelintsev

Age.-Coniacian.

Occurrence.-USSR (Transcaucasus).

Actaeonella obliquestriata Stoliczka, 1859

(see Actaeonella laevis laevis (Sowerby)) 
Trochactaeon (Trochactaeon) obtusa (Zekeli)

1852. Actaeonella obtusa Zekeli

1856. A. obtusa Bronn

?1899. A. obtusa d'Alessandri

1939. A. obtusa Delpey

1951. A. obtusa Pas̃ić

1965. A. obtusa Homaoui and Raab

1976. Spiractaeon obtusa Hacobjan (Hacobjan included Trochactaeon gracilis Pchelintsev, 1954; T. darwasensis Djalilov, 1964 (part); and $T$. (Trochactaeon) lamarcki brandenbergensis Kollmann, 1967 as synonyms)

Age.-Cenomanian-Santonian.

Occurrence.-Austria; Italy; Yugoslavia; Lebanon; Israel; USSR (?Tadzhinsk SSR).

Actaeonella (Trochactaeon) occidentalis Böse, 1906

(see Trochactaeon (Mexicotrochactaeon) coniformis (Böse) 1906)

Actaeonella cf. A. (Trochactaeon) occidentalis Maldonado-Koerdell, I950 (see Trochactaeon (Neocylindrites) punctatus Maldonado-Koerdell)

Actaeonella olivaeformis Cossmann

1896. Actaeonella olivaeformis Cossmann

1902. A. olivaeformis Cossmann

Age.-Garumnien (Maastrichtian).

Occurrence.-France (Ariège).

Trochactaeon (Neocylindrites) oliviformis (Coquand)

1865. Actaeonella oliviformis Coquand

1887. A. oliviformis Mallada

1909. Trochactaeon oliviformis Cossmann

1949. Actaeonella oliviformis Battaler

Age.-Aptian.

Occurrence.-Spain (Tereul).

Trochactaeon (Trochactaeon) ornatus Pchelintsev

1953. Trochactaeon ornatus Pchelintsev

1976. Paleotrochactaeon ornatus Hacobjan

Age.-Cenomanian.

Occurrence.-USSR (Transcaucasus).

Actaeonella orientale Pchelintsev

1960. Actaeonella orientale Pchelintsev

Age.-Early Senonian.

Occurrence-USSR (eastern Siberia, Sikhote-Alin).

Actaeonella ornata Pchelintsev

1953. Actaeonella ornata Pchelintsev

1972. A. (Pchelinsevella) ornata Djalilov

1974. Actaeonella ornata Hacobjan

1976. A. ornata Hacobjan

1977. A. (Pchelinsevella) ornata Djalilov

\section{Age.-Cenomanian.}

Occurrence.-USSR (Transcaucasus, Armenian SSR).

\section{Actaeonella oviformis Gabb}

1869. Actaeonella oviformis $\mathrm{Gabb}$

1926. A. oviformis Stewart
Age.-Turonian.

Occurrence.-California.

The following have been assigned to Actaeonella oviformis but should be placed elsewhere:

1954. Actaeonella oviformis Popenoe (a Trochactaeon)

1958. A. oviformis Anderson (see Trochacateon (Trochaetaeon) packardi)

1979. A. oviformis Jones, Sliter, and Popenoe (see Trochactaeon (Trochactaeon) packardi Anderson)

Trochactaeon (Trochactaeon) packardi (Anderson)

1902. Actaeonella oviformis Anderson

1916. A. oviformis Packard

1922. A. oviformis Packard

1958. A. oviformis Anderson

1958. A. packardi Anderson

1979. A. oviformis Jones, Sliter, and Popenoe

Age.-Turonian.

Occurrence.-California.

Trochactaeon (Mexicotrochactaeon) palmeri Sohl and Kollmann

Age.-Middle to late Maastrichtian.

Occurrence.-Jamaica; Cuba; Puerto Rico.

Trochactaeon (Trochactaeon) ouremensis Choffat

1901. Trochactaeon giganteus var. ouremensis Choffat

1974. Mesotrochactaeon ouremensis Hacobjan

1976. M. ouremensis Hacobjan

Age.-Turonian.

Occurrence.-Portugal; USSR (Armenian SSR).

Trochactaeon (Trochactaeon) ovalis Pchelintsev

1953. Trochactaeon ovalis Pchelintsev

1974. Mesotrochactaeon ovalis (Pchelintsev) part, Hacobjan, 1974 (pl. 49, fig. 5, pl. 50, figs. 1, 3, 4, to Mesotrochactaeon ellip soides (Fittipaldi))

Age.-Cenomanian.

Occurrence.-USSR (Transcaucasus).

Actaeonella oviformis Gabb of Packard 1916, Anderson I938 (see Trochactaeon (Trochactaeon) packardi (Anderson))

Trochactaeon parvus Stanton, 1947

(see Trochactaeon (Neocylindrites) cumminsi Stanton)

Trochactaeon (Trochactaeon) parva Blanckenhorn

1890. Actaeonella parva Blanckenhorn

1927. A. (Trochactaeon) parva Blanckenhorn

Age.-Cretaceous.

Occurrence.-Syria; Israel.

Trochactaeon? patagonica (Feruglio)

1936. Actaeonella patagonica Feruglio

Age.-Senonian.

Occurrence.-Argentina (Patagonia).

Trochactaeon pamiricum Pchelintsev

1960. Trochactaeon pamiricum Pchelintsev

Age.-? 


\section{Occurrence.-USSR (Pamir Mountains).}

Actaeonella pchelincevi Djalilov

1964. Actaeonella pchelincevi Djalilov

1972. A. (Pchelincevella) pchelincevi Djalilov

1977. A. (P.) pchelincevi Djalilov

Age.-Late Cenomanian.

Occurrence.-USSR (Darvaza, Turkmen SSR).

Trochactaeon (Trochactaeon) pcelinsevi (Hacobjan)

1963. Purpuractaeon pcelinsevi Hacobjan

1972. P. pcelinsevi Hacobjan

1974. P. pcelinsevi Hacobjan

Age.-Late Coniacian.

Occurrence.-USSR (Armenian SSR).

Actaeonella pecosensis Stanton

1947. Actaeonella pecosensis Stanton

Age.-Albian.

Occurrence.-Texas.

\section{Actaeonella praecaucasica Aliev}

1958. Actaeonella praecaucasica Aliev

1959. A. praecaucasica Aliev

1963. A. praecaucasica Aliev

1972. A. (Pchelinsevella) praecaucasica Djalilov

1977. A. (Pchelinsevella) praecaucasica Djalilov

Age.-Cenomanian.

Occurrence.-USSR (Transcaucasus).

Actaeonella (Trochactaeon) planilateralis Böse, 1906 (see Trochactaeon (Mexicotrochactaeon) coniformis (Böse))

Actaeonella (Trochactaeon) planilateralis Böse, Maldonado-Koerdell, I950 (see Trochactaeon (Neocylindrites) punctatus (Maldonado-Koerdell))

Actaeonella pompei Maury $\mathbf{1 9 3 0}$

(see Trochactaeon (Mexicotrochactaeon) burckhardti (Böse))

Actaeonella (Trochactaeon) potosiana Böse, 1906

(see Trochactaeon (Mexicotrochactaeon) coniformis (Böse), 1906

Actaeonella praesulcata Aliev, 1959

(see Sogdianella kurdistanica (Aliev)

Actaeonella (Trochactaeon) prisca (Deshayes) Blanckenhorn, I927 (affinities unknown)

Trochactaeon (Trochactaeon) projectiliformis Kollmann

1967. Trochactaeon (Trochactaeon) projectiliformis Kollmann

Age.-Coniacian-early Santonian.

Occurrence.-Austria.

Actaeonella (Trochactaeon) pruniformis Böse, 1923

(see Trochactaeon (Mexicotrochactaeon) burckhardti (Böse), 1923 ; excludes Trochactaeon pruniformis Hacobjan, 1976. from the Cenomanian of Armenian SSR)

Trochactaeon (Trochactaeon) pseudocylindraceus Pchelintsev

1953. Trochactaeon pseudocylindraceus Pchelintsev

1954. T. pseudocylindraceus Pchelintsev
Age.-Cenomanian.

Occurrence.-USSR (Transcaucasus).

Trochactaeon (Neocylindrites) punctatus (Maldonado-Koerdell)

1950. Actaeonella cf. A. (Trochactaeon) coniformis MaldonadoKoerdell

1950. A. (Trochactaeon) acutissima punctata Maldonado-Koerdell

1950. A. cf. A. (Trochactaeon) occidentalis Maldonado-Koerdell

1950. A. (Trochactaeon) planilateralis Maldonado-Koerdell

Age.-Maastrichtian.

Occurrence.-Mexico (Chiapas).

Trochactaeon quadratus Pchelintsev, 1954

(see Trochactaeon (Neotrochactaeon) ventricosa Hacobjan, 1976)

Actaeonella (Trochactaeon) quadriplicata Böse, 1923 (see Trochactaeon (Mexicotrochactaeon) burckhardti (Böse))

Trochactaeon (Trochactaeon) regularis Pchelintsev

1953. Trochactaeon regularis Pchelintsev

Age.-Cenomanian.

Occurrence.-USSR (Transcaucasus).

Trochactaeon (Trochactaeon) renauxianus (d'Orbigny)

1842. Actaeonella renauxiana d'Orbigny

Age.-Turonian.

Occurrence.-France; Yugoslavia; Lebanon; Romania.

The species listed below have been assigned to Trochactaeon (Trochactaeon) renauxiana but should be placed elsewhere:

1852. Actaeonella renauxiana Zekeli (see Trochactaeon (Trochactaeon) sanctaecrucis Futterer, fide Kollmann, 1967)

1884. A. renauxiana Quenstedt (see $T$. (T.) sanctaecrucis Futterer, fide Kollmann, 1967)

1896. Trochactaeon renauxianus Cossmann (see $T$. (T.) sanctaecrucis Futterer, fide Kollmann, 1967)

?1906. Actaeonella cf. A. renauxiana Oppenheim

1939. A. renauxiana Delpey

1957. Trochactaeon renauxianus Pejović(see T. (T.) giganteus (Sowerby), fide Kollmann, 1967)

1959. Actaeonella (Trochactaeon) renauxiana Pokorný (see T. (T.) sanctaecrucis Futterer, fide Kollman, 1967)

1966. A. (Trochactaeon) aff. A. (T.) renauxiana Todiritą̆-Mihăilescu

1967. A. (Trochactaeon) renauxiana Rahman

1972. Trochactaeon renauxiana Hacobjan

\section{Actaeonella roashensis Abbass}

1963. Actaeonella (Actaeonella) roashensis Abbass

Age.-Santonian.

Occurrence.-Egypt.

Actaeonella robinsoni Sohl and Kollmann

Age-Maastrichtian.

Occurrence.-Jamaica; Mexico.

Trochactaeon robustus Pchelintsev, 1954 (see Trochactaeon pruniformis Böse, fide Hacobjan, 1974) 
Trochactaeon (Mexicotrochactaeon) rossi Sohl and Kollman

1906. Actaeonella (Trochactaeon) aff. gigantea Sowerby, Böse 1968. A. coniformis Böse, Myers (part)

\section{Age.-Middle Maastrichtian.}

Occurrence.-Mexico; Jamaica; Cuba.

Actaeonella rotundata Zekeli, 1852

(to Vernedia of the Itieriidae)

Trochacteaon rugosus G. Aliev, 1959

(to Eotrochactaeon fide Hacobjan 1972,

to the Itieriidae Kollmann and Sohl, 1980)

Actaeonella rustica Anderson, 1958

(see Trochactaeon (Trochactaeon) frazierensis Anderson)

Trochactaeon (Trochactaeon) salomonis Fraas, 1867

1867. Actaeonella salomonis Fraas (= Trochactaeon (Trochactaeon) lamarcki lamarcki)

1903. A. salomonis Dacque (=T. (T.) lamarcki lamarcki, fide Kollmann, 1967; Hacobjan, 1974, removed fig. 6 to Mesotrochactaeon tovusensis Hacobjan)

1903. Trochactaeon salomonis Fortau

1912. Actaeonella (Trochactaeon) salomonis Pervinquière (= Mesotrochactaeon longisulcus Hacobjan, 1974)

1927. A. (T.) salomonis Blanckenhorn

1965. Actaeonella? salomonis Homaoui and Raab (see Trochactaeon (Trochactaeon) longisulcus Hacobjan)

Age.-Late Turonian.

Occurrence.-Israel; Lebanon; Egypt (Abu Roash).

Trochactaeon (Trochactaeon) sanctaecrucis (Futterer)

1852. Actaeonella Renauxiana Zekeli

1852. A. glandiformis Zekeli

1853. A. Renauxiana Reuss

1865. A. gigantea Stoliczka

1884. A. renauxiana Quenstedt

1892. A. Sanctae-Crucis Futterer

1895. A. Sanctae-Crucis Böhm

1896. Trochactaeon Renauxianus Cossmann

1959. Actaeonella (Trochactaeon) renauxiana Pokorný

Age.-Santonian.

Occurrence.-Italy (Venetian Alps); Austria.

Trochactaeon (Trochactaeon) scalatus (Schnarrenberger)

1901. Voluta scalata Schnarrenberger

\section{Age.-Cenomanian.}

Occurrence.-Italy (Venetian Alps).

Actaeonella (Volvulina) schiosensis Böhm, 1895

(see Actaeonella caucasica schiosensis)

[assigned to A. (Pchelincevella) schiosensis by Djalilov, 1972, 1977. and to Acteonella schiosensis by Hacobjan, 1974, 1976])

Trochactaeon? schiosensis (Böhm)

1895. Conus schiosensis Böhm

Age.-Late Cenomanian-early Turonian.

Occurrence.-Italy (Venetian Alps).

\section{Trochactaeon (Trochactaeon) schirabadensis Pchelintsev}

1953. Trochactaeon schirabadensis Pchelintsev
1953. T. asiaticus Pchelintsev

1977. Spiractaeon schirabadensis Djalilov

Age.-Santonian.

Occurrence.-USSR (Tadzhinski depression).

Actaeonella silvae Maury, 1925

(see Trochactaeon (Mexicotrochactaeon) burckhardti (Böse))

Trochactaeon similis Pchelintsev

1954. Trochactaeon similis Pchelintsev

Age.-Early Cenomanian.

Occurrence.-USSR (Armenian SSR).

Actaeonella sinaiensis Abbass

1963. Actaeonella sinaiensis Abbass

Age.-Santonian.

Occurrence.-Egypt (Sinai).

Trochactaeon (Trochactaeon) solidus Pchelintsev

1954. Trochactaeon solidus Pchelintsev

Age.-Late Senonian.

Occurrence.-USSR (Armenian SSR).

Trochactaeon (Trochactaeon) speciosus Pchelintsev

1954. Trochactaeon speciosus Pchelintsev

Age-Coniacian.

Occurrence.-USSR (Transcaucasus).

Trochactaeon stabilis Dvali, 1966

(to Eotrochactaeon fide Hacobjan, 1972, 1976,

to the Itieriidae Kollmann and Sohl, 1980)

Trochactaeon subangustatus Pchelintsev 1953

(see Paleotrochactaeon crisminensis (Choffat)

Trochactaeon subburckhardti Pchelintsev 1954

(part to Trochactaeon pruniformis Hacobjan not Böse,

part to Trochactaeon excelsus Pchelintsev, fide Hacobjan, 1976)

Trochactaeon subglandiformis Pchelintsev, 1954

(see Neotrochactaeon glandiformis Hacobjan, 1974)

Actaeonella sublaevis Briart and Cornet

1865. Actaeonella sublaevis Briart and Cornet

1939. A. (Volvaria) sublaevis Marlière

1972. A. (Pchelintsevella) sublaevis Djalilov

1976. Actaeonella sublaevis Kollmann

1977. Acteonella (Pchelintsevella) sublaevis Djalilov

Age.-Late Albian.

Occurrence.-Belgium; Austria; Texas (herein).

Actaeonella cf. A. sublaevis Briart and Cornet, Sohl, and Kollmann

Age.-Albian to Cenomanian.

Occurrence.-New Mexico.

Trochactaeon subotusus Pchelintsev, 1953

(fig. 16 to Mesotrochactaeon tovusensis

and remainder to Mesotrochactaeon ellipsoides by Hacobjan. 1976)

Trochactaeon subovatus Pchelintsev 1954

(see Neotrochactaeon glandiformis Zekeli, fide Hacobjan, 1976) 
Trochactaeon (Trochactaeon) subpruniformis Pchelintsev

1954. Trochactaeon subpruniformis Pchelintsev

1974. T. pruniformis Böse, Hacobjan

Age.-Coniacian.

Occurrence._USSR (Armenian SSR).

Trochactaeon (Trochactaeon) subrenauxi Pchelintsev

1953. Trochactaeon subrenauxi Pchelintsev

1954. T. subrenauxi Pchelintsev

Age.-Cenomanian.

Occurrence.-USSR (Armenian SSR).

Actaeonella syriaca Conrad, Fraas, 1867

(see Trochactaeon (Trochactaeon) lamarcki lamarcki Sowerby)

Trochactaeon (Trochactaeon) szontaghi (Todiritą̆-Mihàilescu)

1966. Actaeonella szontaghi Todirităa-Mihăilescu

Age.-Late Santonian-early Campanian.

Occurrence.-Romania.

Actaeonella tamandarensis Maury

1930. Actaeonella tamandarensis Maury

Age.-Late Turonian-Santonian.

Occurrence.-Brazil (Pernambuco).

Actaeonella terebellum Cossmann, 1896

(see Actaeonella laevis laevis (Sowerby))

Trochactaeon (Mexicotrochactaeon) teaensis Sohl and Kollmann

Age.-Middle to late Maastrichtian.

Occurrence-_Jamaica; Puerto Rico; Mexico.

Actaeonella terterensis Aliev

1961. Actaeonella terterensis Aliev

1963. A. terterensis Aliev

1972. A. (Pchelincevella) terterensis Djalilov

1977. Acteonella (Pchelincevella) terterensis Djalilov [assigned to Actaeonella uchauxensis by Hacobjan, 1976]

Age-Coniacian.

Occurrence.-USSR (Transcaucasus).

Actaeonella torrubiai Vidal

1921. Actaeonella torrubiai Vidal

1949. A. torrubiai Bataller

Age.-Santonian.

Occurrence.-Spain (Gerona).

Actaeonella toucasiana d'Orbigny, 1950

(see Trochactaeon (Trochactaeon) goldfussi)

Trochactaeon (Trochactaeon) tovusensis (Hacobjan)

1953. Trochactaeon subobtusus Pchelintsev (part)

1976. Mesotrochactaeon tovusensis Hacobjan

Age.-Turonian.

Occurrence.-USSR (Armenian SSR).

Trochactaeon transylvanicus Hojnos, 1921

(see Trochactaeon (Trochactaeon) giganteus subglobosus (Münster))
Actaeonella truncata Stoliczka

1868. Actaeonella truncata Stoliczka

Age-Campanian-Maastrichtian.

Occurrence.-Southern India.

Trochactaeon (Trochactaeon) truncatus Stoliczka

1868. Trochactaeon truncatus Stoliczka

1902. T. truncatum Rehbinder

Age.-Arialoor Group; Campanian-Maastrichtian.

Occurrence.-Southern India; USSR (Astrakhan).

Trochactaeon (Sevanella) tuberculatus Hacobjan

1974. Sevanella tuberculata Hacobjan

1976. S. tuberculata Hacobjan

Age.-Coniacian.

Occurrence-USSR (Armenian SSR).

Actaeonella tumida Makarenko

1961. Actaeonella tumida Makarenko

Age.-Paleocene(?) (reworked).

Occurrence.-USSR (Crimea).

Trochactaeon (Trochactaeon) tumidus Pchelintsev

1953. Trochactaeon tumidus Pchelintsev

1954. T. tumidus Pchelintsev

Age.-Cenomanian.

Occurrence.-USSR (Transcaucasus).

$$
\begin{gathered}
\text { Actaeonella uchauxensis Cossmann } \\
\text { (see Actaeonella caucasica grossouvrei Cossmann) }
\end{gathered}
$$

1896. Actaeonella uchauxensis Cossmann

1974. Acteonella uchauxensis Hacobjan

1976. Actaeonella uchauxensis Hacobjan

Age.-Turonian.

Occurrence.-France (Drôme); USSR (Armenian SSR).

\footnotetext{
Actaeonella (Trochactaeon) variabilis Böse, 1906

(see Trochactaeon (Mexicotrochactaeon) coniformis (Böse):

Actaeonella (Trochactaeon) variabilis Daguin, 1927.

and $A$. (Trochactaeon) cf. variabilis Trechmann

$=$ questionable placement)
}

Trochactaeon (Trochactaeon) variospiralis (Hacobjan)

1976. Spiractaeon variospiralis Hacobjan

Age.-Coniacian.

Occurrence.-USSR (Armenian SSR).

Trochactaeon (Trochactaeon) vasmikuchensis Djalilev

1964. Trochactaeon vasmikuchensis Djalilev

1977. Mesotrochactaeon vasmikuchensis Djalilev

Age.-Cenomanian.

Occurrence.-USSR (Darvaza, Turkmen SSR).

Trochactaeon (Trochactaeon) vediensis (Hacobjan)

1963. Purpuractaeon vediensis Hacobjan

1974. $P$. vediensis Hacobjan

1976. P. vediensis Hacobjan 
Age.-Coniacian.

Occurrence.-USSR (Armenian SSR).

Neotrochactaeon ventricosa (Hojnos) Hacobjan, 1976

(see Trochactaeon (Trochactaeon) giganteus subglobosus (Münster))

Actaeonella voluta d'Orbigny, 1850

(see Trochactaeon (Trochactaeon) lamarcki lamarcki (Sowerby))

Trochactaeon (Trochactaeon) woodsi (Rennie)

1906. Actaeonella (Trochactaeon) sp. Woods

1930. A. (T.) woodsi Rennie

Age.-Santonian-Campanian (Africa); early Maastrichtian (Puerto Rico).

Occurrence.-South Africa (Pondoland); Puerto Rico (San German area).

Trochactaeon (Mexicotrochactaeon) wrighti Sohl and Kollmann

Age.-Maastrichtian.

Occurrence.-Jamaica.

Trochactaeon (Trochactaeon) cf. T. (T.) woodsi (Rennie) Sohl and Kollmann

Age.-Early Campanian.

Occurrence.-Puerto Rico.

Trochactaeon (Trochactaeon) zekelii Pchelintsev

1954. Trochactaeon zekelii Pchelintsev

Age.-Early Senonian.

Occurrence.-USSR (Armenian SSR).

Actaeonella zouparriensis Choffat, 1901

(see Actaeonella caucasica zouparriensis)

Many specimens have been cited in the literature and assigned to either Actaeonella or Trochactaeon but have not merited assignment to a described species. Some specimens do not belong in either genus; others only repeat occurrences based upon well-founded species. In both instances, these specimens contribute nothing to the geographic or stratigraphic data presented here. Listed below, however, are several that bear special mention, as they extend the geographic range or stratigraphic occurrence of the genus and are included on the accompanying maps:

Actaeonella sp. Delpey

1939. Actaeonella sp. Delpey

Age.-Albian.

Occurrence.-Lebanon.

Actaeonella sp. Duboul

1947. Actaeonella sp. Doboul

Age.-Early Campanian.

Occurrence.-France (Provence).
Neocylindrites(?) sp. (Dietrich)

1914. Actaeonella (Trochactaeon) Dietrich

Age.-Aptian.

Occurrence.-East Africa (Tenadaguru).

Actaeonella n. sp. Darteville and Brébion

1932. Actaeonella? sp. Riedel

1956. Actaeonella n. sp. Darteville and Brébion

Age.-Santonian.

Occurrence.-Cameroons.

Trochactaeon sp. Spengler

1913. Trochactaeon sp. Spengler

Age.-Campanian.

Occurrence.-India (Province of Assam).

Actaeonella sp. Sohl and Kollmann

Age.-Middle Albian.

Occurrence.-Puerto Rico.

Trochactaeon (Neocylindrites) sp. A, Sohl and Kollmann

Age.-Maastrichtian.

Occurrence.-Puerto Rico.

Trochactaeon (Neocylindrites) sp. B, Sohl and Kollmann

Age.-Late Albian.

Occurrence.-New Mexico.

Actaeonella sp. Yü

1982. Actaeonella sp. Yü

Age.-Aptian?.

Occurrence.-Qinqhai Province, Tibet.

\section{GENERA AND SPECIES EXCLUDED FROM THE ACTAEONELLIDAE}

White (1888, p. 201-202) diagnosed the genus Cylindritella as follows:

Shell subcylindrical; spire short or moderately extended; aperture narrow, more or less distinctly channeled in front but not beaked, and probably always notched narrowly behind; outer lip simple or everted but anteriorly the columella bears three more or less distinct folds or ridges, the anterior one of which is very oblique, and forms the right side of the anterior channel; the obliquity of each succeeding fold decreases posteriorly so that the posterior one is sometimes nearly transverse. The surface is probably always smooth; the volutions of the spire are flat or slightly convex; the suture inconspicuous; and, in some cases at least, there is more or less callus deposited upon the spire about the posterior end of the aperture as it is sometimes in Oliva.

White (1888) and, subsequently, Zilch (1959) considered Cylindritella as an actaeonellid gastropod. Investigation of White's types, which are kept at the U.S. National Museum of Natural History, Washington, D.C., demonstrate that Cylindritella does not belong to the Opistobranchia but to the Neogastropoda, as was sug- 
gested earlier by Kollmann (1967). This conclusion is based on the following observations:

1. The whorls of Cylindritella are posteriorly very narrow and acute in cut section. They show no subsutural ramp or any other signs of an exhalant siphon.

2. The internal molds of the whorls are anteriorly prolonged and narrow, showing that the shells had a very short siphonal canal.

3. The strength of the columellar plaits decreases from the posterior to the anterior.

Following Kollmann (1967), we suggest that Cylindritella should be transferred to the Marginellidae. We cannot decide here whether it is a distinct genus within this family or whether it belongs to one of the established genera.

Kollmann and Sohl (1980) have provided evidence that the genera Sogdianella Djalilov, 1972, Ovactaeonella Djalilov, 1972 (including Omphaloactaeonella Hacobjan, 1972), Peruviella Olsson 1934, and Eotrochactaeon Hacobjan, 1972, all belong to the nerineacean family Itieriidae rather than to the Actaeonellidae where the original proposers placed them. The following listings reflect these reassignments:

\section{Ovactaeonella agdjakendensis (Aliev)}

1959. Actaeonella agdjakendensis Aliev

1963. A. agdjakenden sis Aliev

1972. Ovactaeonella agdjakendensis Djalilov

1976. Omphaloacteonella agjakendensis Hacobjan

1977. Ovactaeonella agjakendensis Djalilov

Age.-Cenomanian.

Occurrence.-USSR (Azerbaijan SSR).

\footnotetext{
Ovactaeonella anchieti (Choffat), 1888 (see Peruviella dolium (Roemer))

Ovactaeonella armenica (Pchelintsev)
}

1953. Actaeonella armenica Pchelintsev

1972. Ovactaeonella armenica Djalilov

1977. O. armenica Djalilov (assigned to Omphaloacteonella ovata (Pchelintsev) by Hacobjan, 1976)

1982. Ovactaeonella dolium Konovalov and Poyarkova

Age.-Cenomanian.

Occurrence.-USSR (Transcaucasus).

Eotrochactaeon azerbaidjanensis (Aliev)

1961. Trochactaeon azerbaidjanensis Aliev

1963. T. azerbaidjanensis Aliev

1972. Eotrochactaeon azerbaidjanensis Hacobjan

Age.-Cenomanian.

Occurrence.-USSR (Transcaucasus).

Ovactaeonella azerbaidjanica (Aliev)

1959. Actaeonella azerbaidjanica Aliev

1972. Ovactaeonella azerbaidjanica Djalilov

1976. Omphaloacteonella azerbaidjanica Hacobjan

1977. Ovactaeonella azerbaidjanica Djalilov
Age.-Early Coniacian.

Occurrence.-USSR (Transcaucasus).

Ovactaeonella devii (Dvali)

1966. Actaeonella devii Dvali

1967. Acteonella georgica Gambashidze

1972. Ovactaeonella devii Djalilov

1972. Omphaloacteonella devii Hacobjan

1976. Ovactaeonella devii Djalilov

1977. Omphaloacteonella devii Hacobjan

Age-Cenomanian or Turonian.

Occurrence.-USSR (Georgian SSR).

Peruviella dolium (Roemer)

1849. Actaeonella dolium Roemer

1852. A. dolium Roemer

1888. A. anchietai Choffat

1928. Volvulina texana Adkins

1947. Actaeonella dolium Stanton

1956. A. anchietai Darteville and Brébion

1976. Omphaloacteonella anchietai Hacobjan

1979. Peruviella dolium Kollmann and Sohl

1982. Ovactaeonella dolium Konovalov and Poyarkova

Age.-Albian.

Occurrence.-Texas; Mexico (State of Chihuahua); Angola (Dombe-Grande).

Eotrochactaeon dubertreti Hacobjan

1972. Eotrochactaeon dubertreti Hacobjan

Age.-Cenomanian.

Occurrence.-USSR (Transcaucasus).

Ovactaeonella ferjanica Djalilov

1972. Ovactaeonella ferjanica Djalilov

1977. O. ferjanica Djalilov

1982. Ovactaeonella dolium Konovalov and Poyarkova

Age.-Coniacian.

Occurrence.-USSR (Tadzhik SSR-Fergana, Kuraminski Ronge).

Sogdianella gagii (Dvali)

1966. Actaeonella gagii Dvali

1972. A. (Sogdianella) gagii Djalilov

1974. A. gagii Hacobjan

1976. Omphaloacteonella gagii Hacobjan

1977. Actaeonella (Sogdianella) gagii Djalilov

1982. Ovactaeonella dolium Konovalov and Poyarkova

Age.-Turonian.

Occurrence.-USSR (Armenian SSR).

Actaeonella georgica Gambashidze, 1967

(see Ovactaeonella devii (Dvali)

Peruviella gerthi Olsson

1928. Actaeonella cf. A. gigantea Gerth

1934. Peruvia gerthi Olsson

1936. Trochactaeon sergipensis Maury

1944. Peruviella gerthi Olsson

1979. P. gerthi Kollmann and Sohl 
1982. Ovactaeonella dolium Konovalov and Poyarkova

Age.-Middle and late Albian.

Occurrence.-Peru (Amotape region); Brazil (Sergipe Province).

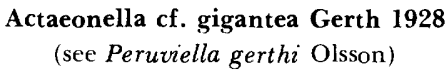

Eotrochactaeon gorindjukensis (Dvali)

1966. Trochactaeon gorindjukensis Dvali

1972. Eotrochactaeon gorindjukensis Hacobjan

Age.-Cenomanian.

Occurrence.-USSR (Transcaucasus).

Sogdianella grandis (Pchelintsev)

1928. Actaeonella grandis Pchelintsev

1953. A. grandis Pchelintsev

1972. A. (Sogdianella) grandis Djalilov

1977. Acteonella (Sogdianella) grandis Djalilov (assigned to Actaeonella crassa Hacobjan, 1976)

Age.-Cenomanian.

Occurrence.-USSR (Transcaucasus).

Sogdinella khalilovi Aliev

1959. Actaeonella khalilovi Aliev

1963. A. khalilovi Aliev

1972. A. (Sogdianella) khalilovi Djalilov

1976. Acteonella khalilovi Hacobjan

1977. A. (Sogdianella) khalilovi Djalilov

Age.-Cenomanian (fide Hacobjan, 1976) Coniacian (fide Djalilov, 1977).

Occurrence.-USSR (Transcaucasus).

\section{Ovactaeonella konstantini (Dvali)}

1966. Actaeonella konstantini Dvali

1972. Ovactaeonella konstontini Djalilov

1982. Ovactaeonella dolium Konovalov and Poyarkova

Age.-Cenomanian.

Occurrence.-USSR (Azerbaijan SSR).

Sogdianella kurdistanica (Aliev)

1959. Actaeonella kurdistanica Aliev

1963. A kurdistanica Aliev

1972. A. (Sogdianella) kurdistanica Djalilov

1977. A. (S.) kurdistanica Djalilov

Age.-Cenomanian.

Occurrence-_USSR (Azerbaijan SSR, Transcaucasus).

Ovactaconella mardakertensis (Aliev)

1961. Actaeonella mardakertensis Aliev

1963. A. mardakertensis Aliev

1972. Ovactaeonella mardakertensis Djalilov

1976. O. mardakertensis Hacobjan

1977. O. mardakertensis Djalilov

\section{Age.-Turonian.}

Occurrence.-USSR (Transcaucasus).
Ovactaeonella ovata (Pchelintsev)

1953. Actaeonella ovata Pchelintsev

1972. Ovactaeonella ovata Djalilov

1974. Actaeonella ovata Hacobjan

1976. Omphaloacteonella ovata Hacobjan

1977. Ovactaeonella ovata Djalilov

1982. Ovactaeonella dolium Konovalov and Poyarkova

\section{Age-Turonian.}

Occurrence.-USSR (Transcauscasus).

Sogdianella peruviana (Olsson)

1934. Actaeonella peruviana Olsson

1979. Sogdianella peruviana Kollmann and Sohl

Age.-Albian.

Occurrence.-Peru (Amotape region).

Sogdianella aff. S. peruviana (Olsson)

1928. Actaeonella (Volvulina) spec. Gerth

1979. Sogdianella aff. S. peruviana Kollmann and Sohl

Age.-Maastrichtian.

Occurrence.-Peru (Paita region).

Sogdianella praesupernata (Djalilov)

1964. Actaeonella praesupernata Djalilov

1972. A. (Sogdianella) praesupernata Djalilov

1977. A. (S.) praesupernata Djalilov

Age.-Albian.

Occurrence.-USSR (Darvaza, Turkmen SSR).

Vernedia repelini (Repelin)

1902. Actaeonella repelini Repelin

Age.-Cenomanian.

Occurrence.-France.

Trochactaeon sergipensis Maury, 1936

(see Peruviella gerthi Olsson)

Sogdianella supernata (Pchelintsev)

1953. Actaeonella supernata Pchelintsev

1954. A. supernata Pchelintsev

1966. A. supernata Lupu

1972. A. (Sogdianella) supernata Djalilov

1974. Acteonella supernata Hacobjan

1976. Omphaloacteonella supernata Hacobjan

1977. Acteonella (Sogdianella) supernata Djalilov

Age.-Cenomanian-early Turonian.

Occurrence.-USSR (Armenian SSR, Transcaucasus).

Sogdianella tagarensis (Arustamov)

1966. Actaeonella tagarenensis Arustamov

1972. A. (Sogdianella) tagarensis Djalilov

Age.-Cenomanian.

Distribution.-USSR (Transcaucasus).

Sogdianella tenuiflexa (Dvali)

1966. Actaeonella tenuiflexa Dvali

1972. A. (Sogdianella) tenuiflexa Djalilov

1976. Omphaloacteonella tenuiflexa Hacobjan 
Age.-Turonian.

Occurrence.-USSR (Georgian SSR).

Sogdianella laevis zehelii (Kollmann)

1852. Actaeonella laevis Zekeli (part)

1965. A. laevis zekelii Kollmann

1972. A. (Sogdianella) zekelii Djalilov

Age.-Late Coniacian.

Occurrence.-Austria.

Eotrochactaeon zumoffeni (Delpey)

1939. Actaeonella zumoffeni Delpey

Age.-Aptian.

Occurrence.-Lebanon.

\section{REFERENCES CITED}

Abbass, H. L., 1963, A monograph on the Egyptian Cretaceous gastropods: [Cairo] Geological Museum, Palaeontological Series, Monograph 2, 146 p., $12 \mathrm{pls}$.

Adkins, W. S., 1928, Handbook of Cretaceous fossils: Texas University, Bureau of Economic Geology and Technology Bulletin 2838, 385 p., 37 pls.

Akopyan, V. T., see Hacobjan, V. T.

Alessandri, G. d', 1899, Fossili Cretacei della Lombardia: Palaeontographica Italica, v. 4, p. 169-202.

Aliev, G. A., 1958 [Stratigraphic significance of Cretaceous gastropods from the Azerbaydzhan region of the Minor Caucasus]: Aka. demiya Nauk Azerbaydzhanskoy SSR, Izvestiya, Seriya GeologoGeograficheskikh Nauk, 1958, No. 4, p. 41-50. (In Azerbay. dzhani; Russian summary.)

1959, [New representatives of opistobranchs from Cenomanian deposits of the Azerbaydzhan part of the Minor Caucasus]: Akademiya Nauk Azerbaydzhanskoy SSR, Izvestiya, Seriya GeologoGeograficheskikh Nauk, 1959, No. 4, p. 41-53, 4 pls. (In Russian.) 1961, [New gastropod species from Upper Cretaceous deposits of the Koshkarchay Terterchay watershed (Minor Caucasus)]: Akademiya Nauk Azerbaydzhanskoy SSR, Izvestiya, Seriya Geologo-Geograficheskikh Nauk, 1961, No. 2, p. 39-50, 4 pls. (In Russian.)

1963, [Cretaceous gastropods from the Minor Caucasus and their stratigraphic significance]: Baku, Akademiya Nauk Azerbaydzhanskoy SSR, Institut Geologiya, 131 p. (In Russian.)

Allison, E. C., 1955, Middle Cretaceous Gastropoda from Punta China, Baja California, Mexico: Journal of Paleontology, v. 29, no. 3 , p. $400-432$, pls. $40-44$.

Anderson, F. M., 1902, Cretaceous deposits of the Pacific Coast: California Academy of Sciences Proceedings, ser. 3, v. 2, p. 1-54.

1938, Lower Cretaceous deposits in California and Oregon: Geological Society of America Special Paper 16, 339 p., 85 pls.

1958, Upper Cretaceous of the Pacific Coast: Geological Society of America Memoir 71, 378 p., 75 pls.

Andert, Hermann, 1934, Die Kreideablagerungen zwischen Elbe und Jeschken. Teil 3. Die Fauna der obersten Kreide in Sachsen, Böhmen und Schlesien: Preussiche Geologische Landesanstalt Abhandlungen, Neue Folge, no. 159, p. 468-477, 19 pls.

Arustamov, A. L., 1966, [On the Senonian gastropods in GaurdakKugitan region]: Akademiya Nauk Turkmenskoy SSR, Ashkabad, Izvestiya, Seriya Fiziko-Tekhnicheskikh, Khimicheskikh i Geologicheskikh Nauk, 1966, no. 1, p. 113-121, 2 pls. (In Russian.)
Bataller, J. R., 1949, Sinopsis de las especies nuevas del Cretácico de España; Pt. 8, Mollusca 2, Gasteropoda: Barcelona, Escuela de Peritos Agrícolas y de Especialidades Agropecuaries y de los Servicios Técnicos de Agricultura Anales, v. 7, p. 5-148.

Beauvais, Louise, and Beauvais, Marcel, 1974, Studies on the world distribution of the upper Cretaceous corals, in Cameron, A. M., and others, eds., Proceedings of the Second International Symposium on Coral Reefs *** 1973: Brisbane, Australia, Great Barrier Reef Committee, v. 1, p. 475-494.

Benkö-Czabalay, Lenke, 1961, Gastéropodes Crétacés de la Hongrie: Hungary, Földtani Intézet, Evkönyve, v. 49, no. 3, p. 739-743.

1964, Die obersenone Gastropodenfauna von Sümeg im südlichen Bakony: Akademie der Wissenschaften, Vienna, Mathematisch-Naturwissenschaftliche Klasse, Sitzungsbericht, Abteilung 1, v. 173, nos. 3 and 4, p. 155-188, pls. 1-2 [1965].

1965, Les gastéropodes de l'Aptien, de l'Albien et du Cénomanien de la Montagne Bakony (Massif Central Hongrois): Hungary, Földtani Intézet, Geologica Hungarica, Series Palaeontologica, no. 31 , p. 230-291, pls. 1-7.

Berryhill, H. L., and Glover, Lynn, 3d, 1960, Geology of the Cayey quadrangle, Puerto Rico: U.S. Geological Survey Miscellaneous Geologic Investigations Map I-319 [1961].

Blanckenhorn, M. L. P., 1890, Beiträge zur Geologie Syriens-Die Entwicklung des Kreidesystems in Mittel- und Nord-Syrien***: Kassel, 135 p., 11 pls.

1927, Die fossilen Gastropoden und Scaphopoden der Kreide von Syrien-Palästina: Palaeontographica, v. 69, p. 111-186, pls. 5-10.

Böhm, Georg, 1895, Beiträge zur Kentniss der Kreide in den Südalpen I. Die Schiosi- und Calloneghe-Fauna: Palaeontographica, v. 41, p. $81-148$, pls. $8-15$.

Böhm, Johannes, 1900, Über cretaceische Gastropoden vom Libanon und vom Karmel: Deutsche Geologische Gesellschaft Zeitschrift, v. 52 , p. $189-219$, pls. 5-7.

Böse, Emil, 1906, La fauna de moluscos del Senoniano de Cárdenas, San Luis Potosí: Mexico Instituto Geológico Boletín 24, 94 p., $18 \mathrm{pls}$.

1923, Algunas faunas cretácicas de Zacatecas, Durango y Guerrero: Mexico Instituo Geológico Boletín 42, 219 p., 19 pls.

Briart, Alphonse, and Cornet, F.-L., 1865, Description minéralogique, géologique et paléontologique de la Meule de Bracquegnies: Académie Royale des Sciences, des Lettres et des Beaux-Arts de Belgique, Brussels, Mémoires, v. 34, no. 2, 92 p., 8 pls.

Briggs, R. P., 1969, Changes in stratigraphic nomenclature in the Cretaceous System, east-central Puerto Rico: U.S. Geological Survey Bulletin 1274-O, p. O1-O31.

Bronn, H. G., and Römer, Ferdinand, 1851-1856, H. G. Bronn's Lethaea Geognostica: Stuttgart, E. Schweizerbart, 3 v. and atlas (124 pls.). (See v. 1 (1851-1856), 1. Übersichten: Theil I, Systematische Übersicht der Fossilien; Schlüssel-Tabellen; Register, by H. G. Bronn, 204 p.; v. 2 (1851-1852), 3. Meso-Lethaea: Theil V, Kreide-Periode, by H. G. Bronn, 412 p., pls. 11-34.)

Choffat, Paul, 1886-1902, ***Espèces nouvelles ou peu connues [de la faune crétacique du Portugal]. Première- [quatrième] série: Portugal Commissão do Servio Geologico, Recueil d'Etudes Paléontologiques sur la Faune Crétacique du Portugal, v. 1, 171 p., 56 pls.

Choffat, Paul, and Loriol, P. de, 1888, Matériaux pour l'étude stratigraphique et paléontologique de la province d'Angola: Société de Physique et d'Histoire Naturelle de Genève Mémoires, v. 30, no. 2,116 p., 8 pls.

Chubb, L. J., 1959, Upper Cretaceous of central Chiapas, Mexico: American Association of Petroleum Geologists Bulletin, v. 43, no. 4, p. $725-756$ 
Collignon, Maurice, 1972, Les gastéropodes et les serpules crétaces du bassin cotier de Tarfaya (Maroc meridional): Morocco Service Géologique Notes et Mémoires 228, p. 9-29, pls. 1-4.

Coney, P. J., Jones, D. L., and Monger, J. W. H., 1980, Cordilleran suspect terranes: Nature, v. 288, no. 5789 , p. 329-333.

Conrad, T. A., 1852, Description of the fossils of Syria, collected in the Palestine Expedition, in Lynch, W. F., Official report of the United States Expedition to Explore the Dead Sea and the River Jordan: Baltimore, John Murphy \& Co., p. [209]-235.

Coquand, Henri, 1854a, Description géologique de la province de Constantine: Société Géologique de France Mémoires, sér. 2, v. 5 , no. 1,155 p., 5 pls.

1854b, Géologie et paléontologie de la région sud de la province de Constantine: Société d'Emulation de la Provence Mémoires, v. 2, 341 p. (also pub. 1862 . Marseille, Arnaud, with atlas, 35 pls.) 1865, Monographie paléontologique de l'étage Aptien de l'Espagne: Société d'Emulation de la Provence Mémoires, v. 3, p. $191-433,28$ pls.

Cossmann, Maurice, 1895, Essais de palaéoconchologie comparée. V. 1: Paris, Presses Universitaires de France, 159 p., 41 figs., 7 pls. 1896, Observations sur quelques coquilles crétaciques recueillies en France: Association Française pour l'Avancement des Sciences Comptes Rendus, v. 25 [pt. 1?], p. 1-27. (Reprint seen.) 1897, Observations sur quelques coquilles crétaciques recueillies en France: Association Française pour l'Avancement des Sciences Comptes Rendus, v. 25 (1896), pt. 2, p. 243-269, 2 pls. 1900 , Observations sur quelques coquilles crétaciques recuillies en France: Association Française pour l'Avancement des Sciences Comptes Rendus, v. 28 (1899), pt. 2, p. 396-402, pls. 1-2. 1903 , Observations sur quelques coquilles crétaciques recueillies en France: Association Française pour l'Avancement des Sciences Comptes Rendus, v. 31 (1902), pt. 2, p. 539-557, pls. 3-4. (Also pub. as: Congrès de Montauban, 1902, art. 5, p. $1-18$.)

1909, Essais de paléoconchologie comparée, no. 8-Purpurinidae et Loxonematidae: Paris, Presses Universitaires de France, 248 p. 4 pls., 87 figs.

1916, Complément de l'étude paléontologique des gisements de Brouzet. Mollusques (Gastropodes et Pélécypodes), in Brun, P. de, Chatelet, C., and Cossmann, Maurice, Le Barrémien supérieur à faciès Urgonien de Brouzet-les-Alais (Gard) (Partie II): Société Géologique de France Mémoire 51, p. 10-35, 5 pls.

Cox, L. R., 1960, Gastropoda-General characteristics of Gastropoda, in Moore, R. E., ed., Treatise on invertebrate paleontology, Part I, Mollusca 1: New York and Lawrence, Kans., Geological Society of America and University of Kansas Press, p. I84-I169.

Czerna, G. A. de, 1956, Pelecípodos y gasteropódos de Cretácico Inferior de la région de San Juan Raya-Zapotitlán, Estado de Puebla: México Universidad Nacional Autonoma, Instituto de Geología, Paleontología Mexicana, no. 2, 47 p., 7 pls.

Dacqué, Edgar, 1903, Mittheilungen Über den Kreidecomplex von Abu Rhoash bei Kairo: Palaeontographica, v. 30, p. 337-392, pls. $34-36$.

1921, Vergleichende biologische Formenkunde der fossilen niederen Tiere: Berlin, Bornträger, 777 p., 345 figs.

Daguin, Fernand, 1927, Contribution à l'étude géologique de la région prérifaine (Maroc occidental): Morocco Service des Mines et de la Carte Géologique, Notes et Mémoires 1, 415 p., $37 \mathrm{pls}$.

Dartevelle, Edmond, and Brébion, Phillipe, 1956, Mollusques fossiles du Crétacé de la côte occidentale d'Afrique du Cameroun à Angola; I, Gastéropodes: Musée Royal Congo Belge Annales, sér. in $-8^{\circ}$, Sciences Géologiques, v. 15, 128 p., 8 pls.

Delpey, Genevieve, 1939, Les gastéropodes mésozoiques de la région Libanaise: France, Haut-Commisariat de la République France en Syrie et au Liban, Section d'Études Géologiques, Notes et Mémoires, 326 p., 11 pls, 189 figs., 4 maps [1940].

Deninger, Karl, 1905, Die Gastropoden der Sächsischen Kreideformation: Beiträge zur Paläontologie und Geologie ÖsterreichUngarns und des Orients, v. 18, 35 p., 4 pls.

Dietrich, W. O., 1914, Die Gastropoden der Tendaguruschicten de Aptstufe und der Oberkreide im sudlichen Deutsch-Östafrica: Gesellschaft naturforschender Freunde zu Berlin, Archiv für Biontologie, v. 3, p. 97-153. (Wissenschaftliche Ergebnisse du Tendaguru-Expedition 1909-1912, Teil 3.)

Djalilov [Dzhalilov], M. R., 1964, [Late Cretaceous gastropods from southwestern Darvaz], in Reiman, V. M., ed. [Paleontology of Tadzhikstan]: Dushambe, Akademiya Nauk Tadzhikskoy SSR, p. 36-66, 13 pls. (In Russian.)

1972, [Systematics of actaeonellids (Gastropoda)]: Paleontologicheskiy Zhurnal, 1972, no. 1, p. 16-23. (In Russian.)

1977, [Cretaceous gastropods from the southeastern part of Central Asia]: Dushambe, Akademiya Nauk Tadzhikskoy SSR, 202 p., 33 pls. (In Russian.)

Dommelen, Hendrik van, 1971, Ontogenetic, phylogenetic, and taxonomic studies of the American species of Pseudovaccinites and Torreites and the multiple-fold hippuritids: Amsterdam, University of Amsterdam, Ph.D. thesis, 125 p., 22 pls.

Douvillé, Henri, 1916a, Le Crétacé et l'Éocéne du Tibet central: India Geological Survey memoirs, Palaeontologia Indica, new ser., v. 5 , no. 3,84 p., 16 pls.

1916b, Les terrains secondaires dans le massif du Moghara à l'est de l'isthme de Suez***. Paléontologie: Académie des Sciences de l'Institut de France Mémoires, 2d sér., v. 54, no. 1, 184 p., 21 pls.

Drescher, R., 1863, Über die Kreide-Bildungen der Gegend von Löwenberg: Deutsche Geologische Gesellschaft Zeitschrift, v. 15, p. 291-366.

Duboul, Cristiane, 1947, La faune Saumatre du Campanien inférieur de la Basse Provence Occidentale: Muséum d'Histoire Naturelle de Marseille Bulletin, v. 7, no. 1, p. 45-63; nos. 2-3, p. 115-163; no. 4 , p. $196-252,4$ pls.

Dujardin, Félix, 1835, Mémoire sur les couches du sol en Touraine, et description des coquilles de la craie et des faluns: Société Géologique de France Mémoire, v. 2, p. 211-312.

Dvali, T. K., 1966 [Gastropoda of the Cretaceous deposits of Georgia [U.S.S.R.]]: Akademiya Nauk Gruzinskoy SSR, Geologicheskiy Institute Trudy, Novaya Seriya, no. 10, 72 p., 14 pls. (In Russian.)

Feruglio, Egidio, 1936, Nota preliminar sobre algunas nuevas especies de moluscos de Supracretáceo y Terciario de la Patagonia: La Plata, Universidad Nacional, Instituto del Museo, Notas, [Ser.] Paleontología, v. 1, no. 6, p. 277-300, pls. 1-2.

Fittipaldi, E. U., 1900, Gastropodi del Calcare turoniano di Sante Polo Matese (Campobasso): R. Accademia delle Scienze, Fisiche e Matematiche, Naples, Atti, ser. 2, v. 10, no. 5, 14 p.

Fourtau, R., 1903, Contribution à l'étude de la faune crétacique d'Egypte: Institut Égyptien Bulletin, ser. 4, no. 4, fasc. 4, p. 231349,5 pls.

Fraas, O. F. von, 1867, Aus dem Orient. V. 1, Geologische Beobachtungen am Nil, auf der Sinai-Halbinsel und in Syrien: Stuttgart, Ebner \& Seubert, p. 1-222, pls. 1-3.

1878, Geologisches [sic] aus dem Libanon: Verein für vaterländische Naturkunde in Württemberg Jahreshefte, v. 34, p. 257-391.

Fretter, Vera, and Graham, Alastair, 1954, Observations on the opisthobranch mollusc Acteon tornatilis (L.): Marine Biological Association of the United Kingdom Journal, v. 33, p. 565-585.

Frič [Fritsch], Anton, 1897, Studien im Gebiete der Böhmischen Kreideformation. Paläontologische Untersuchungen der einzel- 
nen Schichten, VI. Die chlomeker Schichten: Archiv für die naturwissenschaftlichen Landesdurchforschung von Böhmen, v. 10 , no. 4,83 p.

1911, Studien im Gebiete der Böhmischen KreideformationErgänzung zu Band I. Illustriertes Verzeichniss der Petrefacten der Cenomanen Korycaner Schichten: Archiv der naturwissenschaftlichen Landesdurchforschung von Böhmen, v. 15, no. 1, 101 p., 418 figs.

Futterer, Karl, 1892, Die oberen Kreidebildungen der Umgebung des Lago di Santa Croce in den Venetianer Alpen: Pälaontologische Abhandlungen, Neue Folge, v. 2, no. 1, p. 1-124, pls. 1-12.

Gabb, W. M., 1869, Cretaceous and Tertiary fossils, v. 2 of Paleontology [of California]: California Geological Survey, 299 p., 36 pls.

1877, Description of a collection of fossils made by Doctor Antonio Raimondi in Peru: Academy of Natural Sciences of Philadelphia Journal, 2d ser., v. 8, p. 263-336.

Gambashidze, R. A., 1967, [Some mollusks and echinoderms from the Upper Cretaceous deposits of Georgia [USSR]]: Akademiya Nauk Gruzinskoy SSR, Geologicheskiy Institut Trudy, Novaya Seriya, No. 15, p. 54-80. (In Russian.)

Geinitz, H. B., 1871-1875, Das Elbthalgebirge in Sachsen. Erster Theil-Der untere Quader. Zweiter Theil-Der mittlere und obere Quader: Paläontographica, v. 20 (in 2 pts.): pt. 1, 320 p.; pt. 2, 246 p. (See Theil 1, Sec. 8, Gasteropoden, Cephalopoden [etc.]; Theil 2, Sec. 5, Gasteropoden und Cephalopoden.)

Gerth, H., 1928, Neue Faunen der Oberen Kreide mit Hippuriten aus Nordperu: Leidsche Geologische Mededeelingen, v. 2, Aflevering 4, p. 231-241, 4 figs.

Glover, Lynn, III, 1971, Geology of the Coamo area, Puerto Rico, and its relation to the volcanic arc-trench association: U.S. Geological Survey Professional Paper 636, 102 p.

Greco, B., 1916, Fauna cretacea dell' Egitto raccolta dal Figari Bey. Part II. Pisces, Cephalopoda (Addenda) e Gastropoda: Paleontographica Italica, v. 22, p. 103-169, pls. 15-19.

Hacobjan [Akopyan], V. T., 1963, [New Late Cretaceous gastropods of the Armenian Soviet Republic]: Akademiya Nauk Armyan skoy SSR Doklady, v. 36, no. 3, p. 182-188, 2 pls. (In Russian.)

1972, [Systematics of Late Cretaceous trochactaeonids (Gastropoda)]: Paleontologicheskiy Zhurnal, 1972, no. 1, p. 3-15, pls. 1, 2. (In Russian. English translation in Päleontological Journal, v. 6 , no. 1 , p. $1-12$.)

ed., 1974, [Atlas of the fossil fauna of the Armenian SSR]: Erevan, Izd-vo Akademiya Nauk Armyanskoy SSR, 836 p., 199 pls. (In Russian.)

1976, [Late Cretaceous gastropods from the Armenian SSR] Erevan, Izd-vo Akademiya Nauk Armyanskoy SSR, 439 p., 42 pls. (In Russian.)

Herm, Dietrich, 1977, Zyklische Regressions-Sedimentation und Fossil-Vergesellschaftungen in der Gosau (Santonium) von Brandenberg/Tirol: Bayerische Staatssammlung für Paläontologie und historische Geologie Mitteilungen, no. 17, p. 257-277.

Herm, Dietrich, and Schenk, Volker, 1971, Parasitäre, Epökie von Radiolites auf Trochactaeon (Fossilvergesellschaftungen, $\mathrm{nr} .2$ ): Neues Jahrbuch für Geologie und Paläontologie Monatshefte, 1971 , no. 6, p. 324-339.

Hermannsen, A. N., 1846, Indicus generum Malacozoorum primordia***: Kassel, T. Fischer, v. 1, 637 p.

Hojnos, R., 1921, Oberkretazische Gastropoden aus dem Komitate Arad: Földtani Közlöny, v. 50 (1920), Supplement, p. 89-98, pl. 1.

Holzapfel, G. H. E., 1887-1888, Die Mollusken der Aachener Kreide: Paläontographica, v. 34 , p. 29-180, pls. 4-21.

Hamaoui, Maurice, and Raab, M., 1965, Biostratigraphy of the type Shivta and Nezer formations: Israel Geological Survey, Stratigraphic Section 2c, 12 p., 10 pls.
Imlay, R. W., 1944, Cretaceous formations of Central America and Mexico: American Association of Petroleum Geologists Bulletin, v. 28 , no. 8, p. $1077-1195$.

Jones, D. L., Sliter, W. V., and Popenoe, W. P., 1976, Mid-Cretaceous (Albian to Turonian) biostratigraphy of northern California, in International Conference on Mid-Cretaceous Events, 1st, Uppsala, 1975, Événements de la partie moyenne du Crétacé***: Museum d'Histoire Naturelle de Nice Annales, v. 4, p. XXII.1XXII.13.

Kauffman, E. G., 1966, Notes on Cretaceous Inoceramidae (Bivalvia) of Jamaica: Geological Society of Jamaica Journal, v. 8 (Jamaica Geological Survey Publication 97), p. 32-40.

1976, Middle Cretaceous bivalve zones and stage implications in the Antillean Subprovince, Caribbean Province, in International Conference on Mid-Cretaceous Events, 1st, Uppsala, 1975, Evénéments de la partie moyenne du Crétacé***: Museum d'Histoire Naturelle de Nice Annales, v. 4, p. XXX.1-XXX.11.

Kauffman, E. G., and Sohl, N. F., 1974, Structure and evolution of Antillean Cretaceous rudist frameworks: Naturforschende Gesellschaft Basel Verhandlungen, v. 84, no. 1, p. 399-467, 27 figs.

1976, Middle Cretaceous events in the Caribbean Province, in International Conference on Mid-Cretaceous Events, 1st, Uppsala, 1975, Evénéments de la partie moyenne du Crétacé***: Museum d'Histoire Naturellle de Nice Annales, v. 4, p. XXIX.1XXIX.5.

Kennedy, W. J., 1976, The middle Cretaceous of Zululand and Natal, eastern South Africa, in International Conference on MidCretaceous Events, 1st, Uppsala, 1975, Evénéments de la partie moyenne du Crétacé***: Museum d'Histoire Naturelle de Nice Annales, v. 4, p. XVIII.1-XVIII.29.

Kennedy, W. J., and Klinger, H. C., 1975, Cretaceous faunas from Zululand and Natal, South Africa; Introduction and stratigraphy: British Museum (Natural History) Bulletin, Geology, v. 25, no. $4,315 \mathrm{p}$.

Khudoley, K. M., and Meyerhoff, A. A., 1971, Paleogeography and geological history of Greater Antilles: Geological Society of America Memoir 129, 199 p.

Kner, Rudolph, 1852, Neue Beiträge zur Kenntnis der Kreideversteinerungen von Ost-Galizien: Akademie der Wissenschaften, Vienna, Mathematisch-Naturwissenschaftliche Klasse Denkschrift, v. 3, Abt. 1, p. 293-334, pls. 15-17.

Kollmann, H. A., 1964, Stratigraphie und tektonik des Gosaubeckens von Gams (Stiermark, Österreich): Austria Geologische Bundesanstalt, Jahrbuch, v. 107, p. 71-159, 4 pls.

1965, Actaeonellen (Gastropoda) aus der ostalpinen Oberkreide: Naturhistorische Museum Wien Annales, v. 68 (1964), p. 243-262, pls. 1-4.

1967, Die Gattung Trochactaeon in der ostalpinen Okerkreide; zur Phylogenie der Actaeonellidae: Naturhistorische Museum Wien Annales, v. 71 , p. 199-258, 9 pls.

1976, Gastropoden aus den Losensteiner Schichten der Umgebung von Losenstein (Oberösterreich); 1. Teil, Euthyneura und Prosobranchia 1 (Neogastropoda): Naturhistorische Museum Wien Annales, v. 80 , p. $163-206,7$ pls.

1979, Distribution patterns and evolution of gastropods around the Cretaceous-Tertiary boundary, in Christensen, W. K., and Birkelund, Tove, eds., Symposium on Cretaceous-Tertiary boundary events; II, Proceedings, Addendum: Copenhagen, Denmark, University of Copenhagen, p. 83-87.

Kollmann, H. A., and Sohl, N. F., 1980, Western Hemisphere Cretaceous Itieriidae gastropods: U.S. Geological Survey Professional Paper 1125-A, p. A1-A15 [1979].

Kollmann, H. A., and Yochelson, E. L., 1976, Survey of Paleozoic gastropods possibly belonging to the subclass Opisthobranchia: 
Naturhistorisches Museum Wien Annales, v. 80, p. 207-220.

Konovalov, V. P., and Poyarkova, Z. N., 1982, [Actaeonella beds of the Far East and their significance for a regional and interregional correlation of the Cretaceous]: Moskovskoe Obshchestvo Ispytateley Prirody Byulleten, Otdel Geologicheskiy, v. 57, no. 4, p. 65-79, 2 pls. (In Russian.)

Ladd, H. S., Newman, W. A., and Sohl, N. F., 1974, Darwin Guyot, the Pacific's oldest atoll, in Cameron, A. M., and others, eds. Proceedings of the Second International Symposium on Coral Reefs***1973: Brisbane, Australia, Great Barrier Reef Committee, v. 2, p. 513-522.

Lemche, Henning, 1956, The anatomy and histology of Cylichna (Gastropoda Tectibranchia): Spolia Zoologica Musei Hauniensis (København Universitetets Zoologiske Museum Skrifter), [v.] 16 , 278 p., 46 pls.

Levinton, J., 1973, Genetic variation in a gradient of environmental variability-Marine Bivalvia (Mollusca): Science, v. 180, p. 75-76.

Lewis, G. E., and Straczek, J. A., 1955, Geology of south-central Oriente, Cuba: U.S. Geological Survey Bulletin 975-D, p. 171336.

Leymerie, A. F. G. A., 1881, Description géologique et paléontologique des Pyrenées de la Haute-Garonne: Toulouse, E. Privat, 1010 p. (Atlas of 51 pls., dated 1878.)

Lupu, Denisa, 1965, Studiul faunei de gasteropode Cenomaniene de la Chergheş: Studii şi Cercetări de Geologie, Geofizică, Geografie, Seria Geologie, v. 10, no. 1, p. 47-60, pls. 1-4.

1966, Étude de la faune de gastéropodes Cénomaniens de Chergheş: Revue Roumaine de Géologie, Géophysique et Géographie, Série de Géologie, v. 10, no. 1, p. 115-126, pls. 1-4.

MacGillavry, H. J., 1977, Senonian rudists from Curação and BonaireA typical Antillean fauna [abs.] in Caribbean Geological Conference, 8th, Curação, 1977, Abstracts: GUA Papers of Geology, Ser. 1 , no. 9, p. 101-102.

Mahmoud, I. G. E.-d., 1955, Études paléontologiques sur la faune Crétacique du massif du Moghara (Sinai-Égypte): Institute du Désert d'Égypte Publication 8, 195 p., 19 pls.

Makarenko, D. E., 1961, [Mollusca of the Paleocene deposits in Crimea]: Akademiya Nauk Ukrainskoy SSR, Institute Geologichnykh Nauk, Trudy, Seriya Stratigrafii i Paleontologii, no. 40,111 p., 21 pls.

Maldonado-Koerdell, Manuel, 1950, Faunas del Alto Crétacico superior, del Paleoceno y del Eoceno inferior y medio de Chiapas, México: México Escuela nacional de Ciencias Biologicas Anales, v. 6 , nos. $1-4$, p. $181-220$.

Mallada, Lucas, 1887, Sinopsis de las especies fósiles que se han encontrado en Espana; v. 3, Terreno mesozóico: Madrid, M. Tello, $171 \mathrm{p} ., 64 \mathrm{pls}$.

Marlière, Réné, 1939, La transgression Albienne et Cénomanienne dans le Hainaut (études paléontologiques et stratigraphiques): Musée Royal d'Histoire Naturelle de Belgique Mémoire 89, 440 p., 8 pls.

Marincas, Valeria, 1966, Revizuirea acteonelelor din regiunea Sebes: Babes-Bolyai Universitas, Studia, Ser. Geologia-Geographia, v. 11 , no. 1 , p. 21-35, pls. 1-3. (Summaries in Russian and German.)

Matheron, P. P. E., 1842, Genre Itieria: Société Géologique de France Bulletin, Sér. 1, v. 13, p. 493-494.

Maury, C. J., 1925, Fosseis terciarios do Brasil com descripção de novas formas Cretaceas: Brazil Serviço Geologico e Mineralogico Monographia 4, 711 p., 24 pls.

1930, O Cretaceo da Parahyba do Norte: Brazil Serviço Geologico e Mineralogico Monographia 8, 305 p., 35 pls., map.

1936, O Cretaceo de Sergipe: Brazil Serviço Geologico e Mineralogico Monographia 11, 283 p., 28 pls.
Meek, F. B., 1863, Remarks on the family Actaeonidae, with descriptions of some new genera and subgenera: American Journal of Science, 2d ser., v. 35, p. 84-94.

Merriam, C. W., 1941, Fossil Turritellas from the Pacific Coast region of North America: California University Department of Geological Sciences Bulletin, v. 26, no. 1, 214 p., 19 figs., 1 map.

Mitzopoulos, M., 1959, Erster Nachweis von Gosauschichten in Greichenland: Akademie der Wissenschaften, Vienna, Mathematisch-Naturwissenschaftliche Klasse, Sitzungsberichte, Abt. I, v. 168 , no. 1 , p. $79-93,2$ pls.

Moore, D. R., 1956, Observations of predation on echinoderms by three species of Cassidae: Nautilus, v. 69, no. 3, p. 73-76.

Müller, Joseph, 1851, Monographie der Petrefacten der Aachener Kreideformation: Bonn, Henry \& Cohen, $2 \mathrm{v}$. in 1, 6 pls

1859, Monographie der Petrefacten der Aachener Kreideformation. Supplementheft: Aachen, J. A. Mayer, 32 p., 2 pls.

Münster, G. G. zu, 1844, in Goldfuss, G. A., Petrefacta Germaniae*** v. 3: Dusseldorf, Arnz, p. 1-28, pls. 166-199.

Myers, R. L., 1968, Biostratigraphy of the Cárdenas Formation (Upper Cretaceous), San Luis Potosí, México: México Universidad Nacional Autónoma, Instituto de Geología, Paleontología Mexicana, No. 24, 89 p., 16 pls.

Nuttall, C. P., 1969, Acteonella d'Orbigny, 1842 [Gastropoda]Proposed designation of a type-species under the plenary powers Z.N.(S.) 1858: Bulletin of Zoological Nomenclature, v. 25, pts. 4/5, p. $190-192$.

Nuttall, C. P., and Leong, K. M., 1972, Occurrence of Acteonella (opisthobranch gastropod) in the Cretaceous of Sabah: Malaysia Geological Survey Geological Papers, v. 1, p. 1-9, pl. 1.

Olsson, A. A., 1934, Contributions to the paleontology of northern Peru. [Pt. 6] The Cretaceous of the Amotape region: Bulletins of American Paleontology, v. 20, no. 69, 104 p., 11 pls., map.

1944, Contributions to the paleontology of northern Peru. Pt. 7, The Cretaceous of the Paita region: Bulletins of American Paleontology, v. 28, no. 111, 147 p., 17 pls.

Oppenheim, Paul, 1892, Ueber einige Brackwasser- und Binnenmollusken aus der Kreide und dem Eocän Ungarns: Deutsche geologische Gesellschaft Zeitschrift, v. 44, p. 697-819.

1906, Neue Beiträge zur Geologie und Paläontologie der Balkanhalbinsel: Deutsche geologische Gesellschaft Zeitschrift, v. 58, p. $109-180$, pl. 8 .

Orbigny, A. D. d', 1842-1847, Terrains Crétacés. V. 2, Gastéropodes: Paris, Victor Masson, 456 p., pls. 149-236. (Paléontologie Francaise. $1^{\circ}$ sér. Description des mollusques et rayonnes fossiles.)

1850, Prodrome de paléontologie statigraphique universelle des animaux mollusques et rayonnes, faisant suite au conrs élémentaire de paléontologie et de géologie stratigraphique: Paris, Victor Masson, v. 1, 392 p.

Packard, E. L., 1916, Faunal studies in the Cretaceous of the Santa Ana Mountains of southern California: California University, Department of Geology Bulletin, v. 9, no. 2, p. 137-159.

1922, New species from the Cretaceous of the Santa Ana Mountains: California University, Department of Geological Sciences Bulletin, v. 13 , no. 10, p. 413-462, 15 pls.

Parker, R. H., 1975, The study of benthic communities-A model and a review: Amsterdam, Elsevier, 279 p.

Pašić, Milena, 1951, [La fauna de gastéropodes dans la base de la couche "V" du charbon a Kukuljaš-La mine de Rtanj (la Serbie orientale)]: Geološki Anali Balkanskoga Poluostrva (Annales Géologiques de la Péninsule Balkanique), v. 19, p. 57-76, pls. 1-3. (In Serbian; summary in French.)

Pchelintsev, V. F., 1928a [Gastropoda from the Cretaceous beds of the district of Kuban]: Comité Géologique Leningrad Bulletin, v. 46, p. 1175-1193. (In Russian; summary in English.) 
1928b, [The Mesozoic Gastropoda of Transcaucasia]: Comité Géologique Leningrad Bulletin, v. 46, p. 1194-1202. (In Russian.) 1953, [Gastropod fauna of the Upper Cretaceous deposits of Transcaucasia and Central Asia]: Akademiya Nauk SSSR, Geologicheskiy Muzei, Seriya Monograficheskaya, no. 1, 391 p., 51 pls., 47 figs. (In Russian.)

1954, [Gastropods from the Upper Cretaceous beds of the Armenian SSR and from adjoining parts of Azerbaidzhanian SSR]: Akademiya Nauk SSSR, Geologicheskiy Muzei, Seriya Monograficheskaya, no. 2, 180 p. (In Russian.)

1960, [New data on the Lusitanian fauna of the Pamir Mountains]: Adademiya Nauk SSSR, Geologicheskiy Muzei Trudy, Novaya Seriya, no. 2, p. 7-18, 4 pls. (In Russian.)

1963, [Mesozoic gastropods from the Crimean mountains]: Moscow-Leningrad, Akademiya Nauk SSSR, Geologicheskiy Muzei, 131 p., 22 pls. (In Russian.)

Pchelintsev, V. F., and Korobkov, I. A., eds., 1960, MollyuskiBryukhonogie, [v. 4] of Orlov, Y. A., ed., Osnovy paleontologii, spravochnik dlya paleontologov i geologov SSSR: Moscow, Akademiya Nauk SSSR, 360 p., 28 pls.

Pejović, Desanka, 1957, [Geologie und Tektonik der weiteren Umgebung von Pócuta (Westserbien) mit besonderer Berücksichtigung der Biostratigraphie der oberkretazischen Bildungen]: Srpska Akademija Nauka, Belgrad, Posebna izdanja, Geološki Institute, Knjiga 8, 147 p., 45 pls. (In Serbian; summary in German.)

Pervinquière, Léon, 1912, Études de paléontologie tunisienne. II, Gastéropodes et lamellibranches des terrains crétacés: Paris, F. R. de Rudeval, 352 p., 23 pls.

Pessagno, E. A., Jr., 1976, Middle Cretaceous planktonic foraminiferal biostratigraphy of the Antillean-Caribbean region and eastern Mexico; notes on the ammonites of eastern Mexico, in International Conference on Mid-Cretaceous Events, 1st, Uppsala 1975, Événements de la partie moyenne du Crétacé***: Museum d'Histoire Naturelle de Nice annales, v. 4, p. XXVIII.1-XXVIII.10.

Pethö, Julius [Gyula], 1906, Die Kreide- (Hypersenon-) Fauna des Peterwardiener (Pétervárader) Gebirges (Fruska Gora): Palaeontographica, v. 52 , nos. 2-6, p. 57-331, pls. 5-26.

Philippi, R. A., 1851, Ueber Tornatella abbreviata, Otodus mitis, Otodus catticus and Myliobatis testae: Palaeontographica, v. 1, p. 23-25, pl. 2.

Pokorný, G., 1959, Die Actaeonellen der Gosauformation: Österreich Akademie der Wissenschaften, Mathematisch-Naturwissenschaftliche Klasse, Sitzungsbericht, Abt. 1, v. 168, no. 10, p. 945978, pls. 1-2, 1 fig.

Ponder, W. F., 1973, The origin and evolution of the Neogastropoda; Malacologia, v. 12 , no. 2, p. 295-338.

Popenoe, W. P., 1954, Mesozoic formations and faunas, southern California and northern Baja California [Mexico], [pt. 3], in Chap. 3 of Jahns, R. H., ed., Geology of southern California: California Division of Mines Bulletin 170, p. 15-21.

Purchon, R. D., 1968, The biology of the Mollusca: Oxford, Pergamon Press, $560 \mathrm{p}$.

Quenstedt, F. A. von, 1881-1884, Petrefactenkunde Deutschlands. V. 7, nos. 1-6, Die Gasteropoden: Leipzig, 866 p. (no. 1, 1881; nos. 2 and 3,1882 ; no. 4,1883 ; nos. 5 and 6,1884 ); atlas, pls. 185 218.

Rahman, Asisu, 1967, Die Gastropoden der Oberkreide (OberCenoman) von Hölzelsau bei Niederndorf im Tirol: Bayerische Staatsammlung für Paläontologie und Historische Geologie Mitteilungen, No. 7, p. 23-134, 7 pls.

Rehbinder, Boris von, 1902, Fauna und alter der cretaceischen Sandsteine in der Umgebung des Salzsees Baskuntschak***: Comité Géologique St. Petersbourg Mémoires, v. 17, no. 1, 84 p.
Riedel, Leonard, 1932, Die Oberkreide vom Mungofluss in Kamerun und ihre Fauna: Beiträge zur Geologischen Erforschung der deutschen Schutzgebiete, no. 16, 154 p., 32 pls.

Remane, Adolf, 1963, Biologische Kriterien zur Unterscheidung von Süss-und Salzwassersedimenten: North Rhine-Westphalia, Geologisches Landesamt Fortschritte in der Geologie von Rheinland und Westfalen, v. 10, p. 9-34.

Rennie, J. V. L., 1930, New Lamellibranchia and Gastropoda from the Upper Cretaceous of Pondoland (with an appendix on some species from the Cretaceous of Zululand): South African Museum Annals, v. 28, pt. 2, p. $159-260$, pls. $16-31$.

Repelin, Joseph, 1902, Description des faunes et des gisements du Cénomanien Saumatre ou d'eau douce du Midi de la France: Marsailles, Musée d'Histoire Naturelle Annales (Géologie), v. 7 (1901-1902), pt. 2, p. 25-112, 8 pls. (Title page for entire v. 7 bears title of work cited here, but v. 7 also contains two other reports, one preceding and one following pt. 2, by different authors and having different titles.)

Reuss, A. E., 1845-1846, Die Versteinerungen der Böhmischen Kreiderformation: Stuttgart, E. Schweizerbart, 2 v. in 1, pls. 1-51. 1853, Kritische Bemerkungen über die von Herrn Zekeli beschriebenen Gasteropoden der Gosaugebilde in den Ostalpen: Akademie der Wissenschaften, Vienna, Mathematisch-Naturwissenschaftliche Klasse, Sitzungsberichte, v. 11, p. 882-923.

Roemer, Ferdinand, 1849, Texas***: Bonn, Adolf Marcus, 464 p. 1852, Die Kreidebildungen von Texas und ihre organischen Einschlüsse: Bonn, Adolf Marcus, 100 p., 11 pls.

Roman, Frédéric, and Mazeran, Pierre, 1920, Monographie paléontologique de la faune du Turonien du Bassin d'Uchaux et de ses dépendances: Lyons Muséum d'Histoire Naturelle, Archives, v. 12 (Mémoire 2), 137 p., 11 pls.

Rose, P. R., 1972, Edwards Group, surface and subsurface, central Texas: Texas University, Bureau of Economic Geology Report of Investigations 74, 198 p., 19 pls., 35 figs.

Sayn, Gustave, 1932, Description de la faune de l'Urgonien de Barcelonne (Drôme): Lyon Université, Faculté des Sciences, Laboratoire de Géologie Travaux, pt. 18 (Mémoire 15), 70 p., 4 pls.

Schafhäutl, K. F. E. von, 1863, Sud-Bayerns Lethaea Geognostica. Der Kressenberg und die südlich von ihm gelegenen Hochalpen***: Leipzig, L. Voss, 487 p., 98 pls., 2 maps.

Schenk, Volker, 1972, Fossil-Vergesellschaftungen, Nr. 3-Zur Regressionsfazies (Biofazies und Ökologie) der mittleren Gosau (O. Kreide) von Brandenberg, Tirol: Neues Jahrbuch für Geologie un Paläontologie Monatshefte, Jahrgang 1972, no. 4, p. 236-256.

Schnarrenberger, Carl, 1901, Über die Kreideformation der Monte d'Ocre-Kette in den Aquilaner Abruzzen: Naturforschende Gesellschaft zu Freiburg i B., Berichte, v. 11, no. 3, p. 176-214, 4 pls.

Sedgwick, Adam, and Murchison, R. I., 1832, A sketch of the structure of the eastern Alps; with sections through the newer formations on the northern flanks of the chain, and through the Tertiary deposits of Styria, etc., etc.: Geological Society of London Transactions, 2 d ser., v. 3 , pt. 2 , p. 301-420, pls. 35-40. (See references to identifications by J. De C. Sowerby, p. 330, 347, 359-360, 388, 417-420; also pls. 37 and 38.)

Shuto, Tsugio, 1974, Larval ecology of prosobranch gastropods and its bearing on biogeography and paleontology: Lethaia, v. 7, no. 3, p. 239-256.

Smith, A. G., and Briden, J. C., 1977, Mesozoic and Cenozoic paleocontinental maps: Cambridge (England) and New York, Cambridge University Press, 63 p. 52 maps.

Smith, A. G., Briden, J. C., and Drewry, G. E., 1973, Phanerozoic world maps: Palaeontological Association Special Papers in Palaeontology, no. 12, p. 1-42. 
Smith, A. G., Sohl, N. F., and Yochelson, E. L., 1968, New Upper Cretaceous Amphineura (Mollusca): U.S. Geological Survey Professional Paper 593-G, 9 p., 1 pl.

Sohl, N. F., 1964, Neogastropoda, Opisthobranchia, and Basommatophora from the Ripley, Owl Creek, and Prairie Bluff formations: U.S. Geological Survey Professional Paper 331-B, p. 153344 , pls. $19-52$.

1969, The fossil record of shell boring by snails: American Zoologist, v. 9, no. 3, ed. 2, p. 725-734.

1971, North American Cretaceous biotic provinces delineated by gastropods, in Yochelson, E. L., ed., Cretaceous biogeography: North American Paleontological Convention, Chicago, 1969, Proceedings, pt. L, p. 1610-1638, 13 figs.

1977, Cenomanian mollusks from Martha's Vineyard, Massachusetts, in Geological Survey Research 1977; U.S. Geological Survey Professional Paper 1050, p. 203 [1978].

1979, Notes on middle Cretaceous macrofossils from the Greater Antilles, in International Conference on Mid-Cretaceous Events, 1st, Uppsala, 1975, Événements de la partie moyenne du Crétacé***: Museum d'Histoire Naturelle de Nice Annales, v. 4 p. XXXI.1-XXXI.6.

Sowerby, J. De C., see Sedgwick, Adam, and Murchison, R. I., 1832

Spengler, Erich, 1910, Untersuchungen über die südindische Kreideformation. Die Nautiliden und Belemniten des Trichinopoly. distriktes: Beiträge zur Paläontologie und Geologie ÖsterreichUngarns und des Orients, v. 23, no. 3, p. 125-157, pls. 11(26)14(29).

1913, Nachträge zur Oberkreidefauna des Trichinopolydistriktes in Südindien: Beiträge zur Paläontologie und Geologie Osterreich-Ungarns und des Orients, v. 26, no. 3-4, p. 213-239, pls. 14(1)-15(2).

Stanton, T. W., 1947, Studies of some Comanche pelecypods and gastropods: U.S. Geological Survey Professional Paper 211, 256 p., 67 pls.

Steinmann, Gustav, 1929, Geologie von Peru: Heidelberg, C. Winter, 448 p., 9 pls., 271 figs., 1 map.

Stewart, R. B., 1927, Gabb's California fossil type gastropods: Academy of Natural Sciences of Philadelphia Proceedings, v. 78 (1926), p. 287-447, pls. 20-32.

Stoliczka, Ferdinand, 1860, Über eine der Kreideformation angehörige Süsswasserbildung in den nordöstlichen Alpen: Akademie der Wissenschaften, Vienna, Mathematisch-Naturwissenschaftliche Klasse, Sitzungsberichte, v. 38 (Jahrg. 1859, no. 25), p. 482-496, $1 \mathrm{pl}$.

1866, Eine Revision der Gastropoden der Gosauschichten in den Ostalpen: Akademie der Wissenschaften, Vienna, MathematischNaturwissenschaftliche Klasse, Sitzungsberichte, v. 52, Abteilung 1 (Jahrg. 1865, no. 7), p. 104-223, 1 pl

1868, The Gastropoda, v. 2 of Cretaceous fauna of southern India: India Geological Survey Memoirs (Paleontologia Indica, pts. 1-10, 1867-1868), 497 p., 28 pls.

Struhsaker, J. W., 1968, Selection mechanisms associated with intraspecific shell variation in Littorina picta (Prosobranchia: Mesogastropoda): Evolution, v. 22, no. 3, p. 459-480.

Termier, Geneviève, and Termier, Henri, 1952, Classe des gastéropodes, in Traité de Paléontologie, v. 2: Paris, Masson, p. 365-460, figs. 1-214.

Thorson, Gunnar, 1965, A neotonous dwarf-form of Capulus ungaricus (L.) (Gastropoda, Prosobranchia) commensalistic on Turritella communis Risso: Ophelia, v. 2, no. 1, p. 175-210.

Todiriţă-Mihăilescu, Victoria, 1966, Studiul geologic al bazinului
Roşia: Romania Comitetul de Stat al Geologiei, Institutul Geologic, Studii Tehnice şi Economice, Ser. J., Stratigrafie, no. 3, $111 \mathrm{p} ., 62 \mathrm{pls}$

Trechmann, C. T., 1929, Fossils from the Blue Mountains of Jamaica: Geological Magazine, v. 66, no. 785, p. 481-491.

Vereshchagin, V. N., and Pchelintsev, G. F., 1960, [Finding of actaeonellids at Sikhote-Alin, eastern Siberia]: Akademiya Nauk SSR, Geologicheskiy Muzei Trudy, Novaya Seriya, no. 2, p. 40-44, 1 pl. (In Russian.)

Vidal, L. M., 1921, Contribución a la paleontologia del Cretacio de Cataluna: Academia de Ciencias y Artes, Barcelona, Memorias, Tercera Epoca, v. 17, no. 2, p. 89-107, 8 pls. (Also paged separately, p. 1-21.)

Vogel, Klaus, 1968, Zur Lebensweise des Gastropoden Nerinea: Neues Jahrbuch für Geologie und Paläontologie Monatshefte, no. 3, p. 181-184.

Weinzettl, Valentin, 1910, Gastropoda Českého Ǩrídového Útvaru: Palaeontographica Bohemiae, C. 8, 56 p., 7 pls.

White, C. A., 1888, Contributions to the paleontology of Brazil; comprising descriptions of Cretaceous invertebrate fossils, mainly from the provinces of Sergipe, Pernambuco, Para and Bahia: Rio de Janeiro, Museu Nacional Archivos, v. 7, 273 p., 28 pls.

Whiteaves, J. F., 1884, On the fossils of the coal-bearing deposits of the Queen Charlotte Islands: Canada Geological Survey, Mesozoic Fossils, v. 1, pt. 3, p. 191-262, pls. 21-32.

Whitfield, R. R., 1891, Observations on some Cretaceous fossils from the Beyruit district of Syria, in the collection of the American Museum of Natural History, with descriptions of some new species: American Museum of Natural History Bulletin, v. 3, p. 381441, pls. 4-11.

Wolff, H., 1970, Gastropodenfauna und Biotope des Oberalb (+Vraconnien) vom Tennboden (Bayerische Kalkalpen, Chiemgau): Munich, University of Munich, Ph.D. dissert., 208 p., 7 pls.

Woods, Henry, 1906, The Cretaceous fauna of Pondoland: South African Museum Annals, v. 4, p. 275-350, pls. 33-44.

Yonge, C. M., 1946, On the habits of Turritella communis Risso: Marine Biological Association of the United Kingdom Journal, v. 26 , p. $377-380$.

Young, Keith, 1972, Cretaceous paleogeography-Implications of endemic ammonite faunas: Texas University, Bureau of Economic Geology Gelogic Circular 72-2, 13 p.

Yü, Wen, 1982, [Some fossil gastropods from Xizang], in [Series of the Scientific Expedition to the Qinghai-Xizang Plateau. Paleontology of Xizang, Book 4]: Beijing, China, Science Press, p. 255-281, 10 pls. (In Chinese; abstract in English.)

Zapfe, Helmuth, 1937, Paläobiologische Untersuchungen an Hippuritenvorkommen der nordalpinen Gosauschichten: ZoologischBotanische Gesellschaft in Wien, Verhandlungen, v. 86/87, p. $73-124,2$ pls., 8 figs.

Zekeli, Friedrich, 1852, Die Gastropoden der Gosaugebilde: K.-K. Geologosche Reichsanstalt [Vienna] Abhandlung, v. 7, Abt. 2, no. 2,124 p., 24 pls.

Zeller, R. A., 1965, Stratigraphy of the Big Hatchet Mountains area, New Mexico: New Mexico Bureau of Mines and Mineral Resources Memoir 16, 128 p.

Zilch, Adolf, 1959-1960, Gastropoda, Teil 2, Euthyneura, in Schindewolf, O. H., Handbuch der Paläozoologie, v. 6: Berlin, Borntraeger, $834 \mathrm{p}$.

Zittel, K. A. von, 1881-1885, Handbuch der Paläozoologie. V. 2, Molluska und Arthropoda: Munich and Leipzig, 893 p., 1109 figs. 



\section{INDEX}

[Italic page numbers indicate major references]

\begin{tabular}{|c|c|}
\hline Page & Page \\
\hline A & $\begin{array}{l}\text { grossouvrei - } \\
\text { inconstans- }\end{array}$ \\
\hline abbreviata, Actaeonella -_- & inflata--- 73,81 \\
\hline Actaeonella (Trochactaeon) - & involuta-___ \\
\hline Nerinea-_-_-_-_ & jicarensis -_- $7,35,69,70 f, 81 ;$ pls. $19,20,22,23$ \\
\hline abbreviatus, Trochactaeon & khalılovi -_-_ 65,89 \\
\hline Trochactaeon (Neocylindrites) -_- & konstantttl -- \\
\hline absalonis, Trochactaeon-_- & 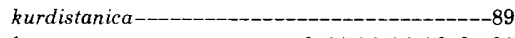 \\
\hline Trochactaeon (Neocylindrites) -_-_-_-_-_ & laevts - $9,64,70,72,79,81,90$ \\
\hline abstract-_-_-_-_ & $81,82,86$ \\
\hline acknowledgments - & 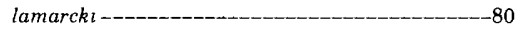 \\
\hline Actaeon---_-_-_-_ & -_-_-_-_-_-_-_-_-_-_o \\
\hline Actaeon giganteus -- & luciana --_-_- 59 \\
\hline Actaeon tornatills-_- & luciano-_-_ \\
\hline burrowing behavior -- & marchmontensıs --_--- $35,71,71 f, 72,82, \mathrm{pl} .21$ \\
\hline Actaeonell crassa --_ & mardakertensis-_- 89 \\
\hline gractls -------18 & 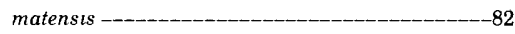 \\
\hline Actaeonella-_-_ & obliquecostata_a_ 81,82 \\
\hline abbreviata---_-- 75 & -_-_-_-_-_-_-_-_-_-_-_-_-_83 \\
\hline acuminata___ 75,76 & - \\
\hline agdjakendensts-_-_- 88 & olviaformis -_- 83 \\
\hline agricolat - -20.75 & olut formis-__- 20,83 \\
\hline anchietai-_-_-_- 88 & ortentale - \\
\hline armentca-- & _- 65,83 \\
\hline azerbatdjantca -_-_-_-_ & oeata - \\
\hline baconica - - & oviform is-_- $35,51,52,68,83 ;$ pl. 18 \\
\hline beyrichi-_-_-_ 6 & packardl \\
\hline borneensis - & 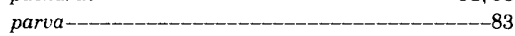 \\
\hline briartt-___ & 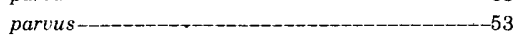 \\
\hline briggsi & patagontca -_____- 83 \\
\hline brownl-_-_-_ $24,67,67 f, 76$, pl. 18 & pchelincevi --_-_-_-_ \\
\hline caucasica-_-__- $64,76,77$ & __ \\
\hline caucasica caucastca --_-_- 76 & pecosensts \\
\hline caucasica grossouvrel -__ & -89 \\
\hline caucasica schiosensis & plantlateralts - \\
\hline caucasica styraca-_-_ & pompei - \\
\hline caucasica zouparrtensts -_-_-_-_-_ 77.87 & 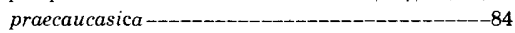 \\
\hline conformis - & praesulcata--__-_- 84 \\
\hline conica --_- 76,77 & praesupernata-_-__-_-_-_-_ \\
\hline coniformis-_- $56,57,58,62,63,85 ;$ pl. 16 & renauxiana - $-47,80,84,85$ \\
\hline coquiensts__- $35,70,70 f, 78 ;$ pls. $2,20,21$ & repeltnt _-_____ 89 \\
\hline crassa-_- $73,77,78,81,82,89$ & 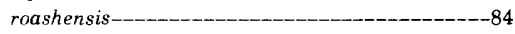 \\
\hline cretacea-_-__ & robinsont_-__- $35,65,69,72,73,84 ;$ pls. $17,22,23$ \\
\hline cubensis - $9,35,65,72,73 f, 78 ;$ pls. $17,22,23$ & 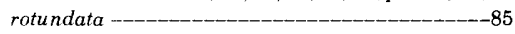 \\
\hline 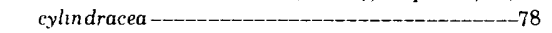 & rustica--_-_-_-_-_-_-_ $50,79,85$ \\
\hline d'Orbigny -__ & salomonis --_-_-_-_-_-_-_-_ \\
\hline decorata - $-65,78$ & Sanctae-Crucus -_-_-_ \\
\hline delgadol-_ & schtosensis - \\
\hline devit - & stlvae-______- 85 \\
\hline doltum $---1--1$ & sinalensis \\
\hline dubertrets - & subglobosa --__-_-_ \\
\hline duckettsensis -_-_-_35, 69, 69f, 72, 79; pls. 19,20 & sublaevis - \\
\hline ellipsoudes & supernata - \\
\hline elliptica-_-_- & syriaca-_-_- 81,86 \\
\hline elongata - & szontaghi \\
\hline$f a b a-1$ & tagarensts - \\
\hline frazterensis -___-_ 50,79 & tamanderensts - \\
\hline fusiform is - $-20,22,79$ & teaensis_-__ \\
\hline gagii - & tenuiflexa - _-_ \\
\hline georgtca --_-_. & 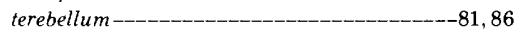 \\
\hline 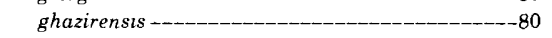 & 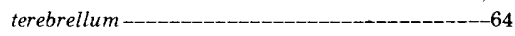 \\
\hline $79,80,85$ & - \\
\hline glandiformis - - & 86 \\
\hline goldfusst-_-_-_. & $-80,86$ \\
\hline gracilis & truncata \\
\hline grandis - & tumida \\
\hline
\end{tabular}

uchauxensis--_-_-_-_-_-_-_-_-_-_---64, 76, 81, 86

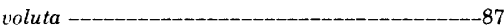
zouparriensis zumoffen 1 --_-_- 90 sp. - sp. B - sp. C spp. --_-_-_-_-_-_-_-_- 74

(Actaeonella) caucasica -_-____-_-_-_-_-_-- 77

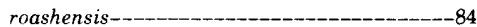

(Pchelincevella) caucasica -______-_-_ crassa -_-_-_-

delgadoi -____-_ 66,79

faba-_-_

gracilis -

grossouvrei -_-_-_ 76

pchelincevi -_-_-_-_-_-__-_-___-_-_-_-_-_

schiosensis -_-

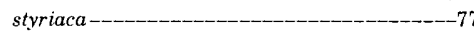

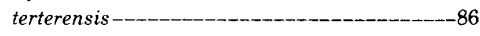

zouparriensis --__-_____

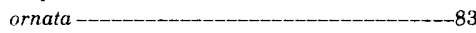

praecaucasica-_-_-_-_-_-_-_-_-_-_-_-_-_-_84

(Pchelintsevella) sublaevis _-_______________-_85

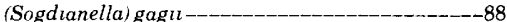

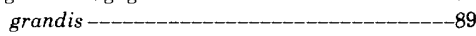

khalilovi --_-_-_-_-_-_-_-_-_-_-_-_-_-_--_89

kurdistanica-_-_-_-_-_-_-_-_-_-_._-_- 89

praesupernata--_-_-_-_---_---_-_-_--89

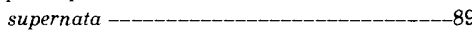

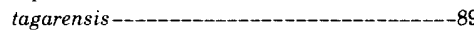

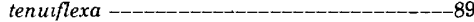

zekelit

(Trochactaeon) abbreviata --_-_-_--

acutissima-_

punctata-____________ $54,56,58,77,84$

angustata -_-_-_- 75

baylei -

brevis-_-_ $48,56,76,77$

burckhardti-______________________ $47,58,76$

collignoni -_-_-_-_-_-_-_-_-_-_-_-_

conica -

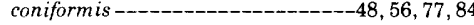

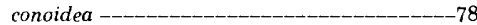

cordeiroi --_-_-_-_- 78

cylindracea ---------------_-----------52,78

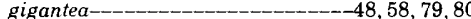

glgantea --_-_-_-_-_-_-_-_-_-_

globosa -

subglobosa --_-_-_-_-_-_-_-_-_-_-_-_

ventricosa--_-_-

goldfussi -

Humboldti-_-_-_-_-_ $58,76,81$

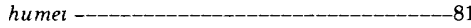

inconstans -

irregularis-____________-_ $48,56,77,81$

lamarcki--_-_-_-_-_-_-_-_-_

matensts -..-_-_-_-_-_-_-__-___-_-_-_-_

occidentalis -_____________-_ $48,56,77,83$

parva

7,83
--83
--78

parvus -

planilateralus-_-__-_-_-_4, 54, 56, 77, 78, 84

potosiana-_______-_-_ $48,56,77,84$

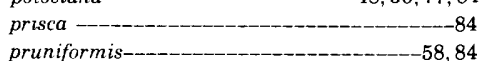

quadriplicata -___________-_ $58,76,84$ 


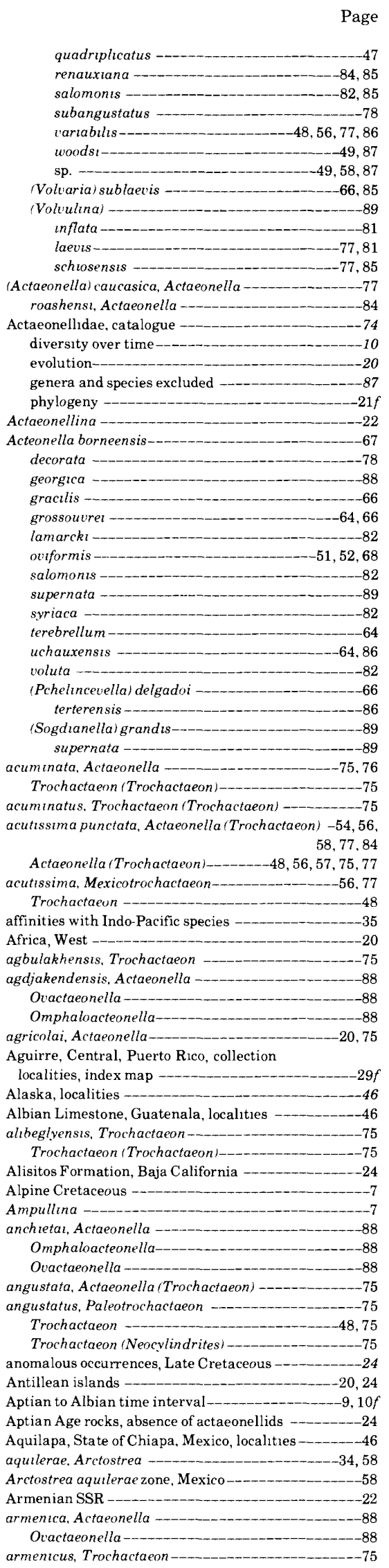

Page

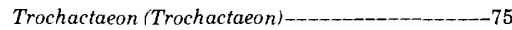
arnaudi, Mesotrochactaeon

Trochactaeon - Trochactaeon (Trochactaeon)--

Trochactaeon (Trochactaeon)-_-__-_-_-_-_-

artsachensis, Mesotrochactaeon-_-_-_-_-_

Trochactaeon (Trochactaeon)-_-_-

Assam Province, India --_-_-

asıaticus, Trochactaeon -....._-_-_-__-_

Trochactaeon (Trochactaeon)-_-_-_associations, lagoonal Astrocoenia, coral--

Austria, associations in shales

atschadjurensis, Trochactaeon --_-_ 75

Trochactaeon (Trochactaeon)_-_____-_-

autochthonous Trochactaeon-_-_-_-_-_-_- 6

azerbatdjanensts, Eotrochactaeon -_______-_

Trochactaeon -_-__-_-_

Actaeonella-_- -88

Omphaloactaeonella-_-_...-_-

Ovactaeonella -_____-_____-_

\section{B}

babkovi. Trochactaeon -_-_-_-_-_-_-_-_

Trochactaeon (Trochactaeon)-_-_-_-_baconica, Actaeonella-__

baconicus, Paleotrochactaeon -_-__-_-_

Trochactaeon -_-_-_-_(Neocylindrites) --_-_-

Baja Calıfornia-_-_- 20

Barrancas Limestone Member, Mayaguez

Foundation, Puerto Rico -

Barranquitas Quadrangle, Puerto Rico, localities $-35,36$ index map - -

Barremian time interval _-____.______ $9,10 f, 11 f$ barremicus, Trochactaeon -_-_-_Trochactaeon (Neocylindrites) ___ $20,48,54,75$

Barrettia coatsi-_-_ gigas -_______-_ monilifera-________-__-34

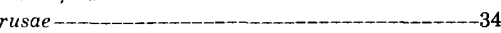
sp. C sp.

Barrettia Limestone, Stapleton Formation, Jamaica 44,71 bayler, Actaeonella (Trochactaeon) -_-_- 76

Trochactaeon (Neocylindrites) - -

belgıca, Trochactaeon-_-_-_-_-_-_-_

belgicus, Trnchactaeon (Neocylindrites) -_-_-_-_-_76

Trochactaeon (Trochactaeon)-_-_____- 77

Bella Vista District, California, localities --_-_-46

bevrichn, Actaeonella-_- 76

Purpuractaeon -____- 76

Trochactaeon (Trochactaeon) _..._- 4, 49, 50, 75, 76

bicincta, Nerinea -_-

biconicus, Trochactaeon-_-_- 76

Trochactaeon (Trochactaeon)-_-_-_-

Big Hatchet Mountain, New Mexico-___-_56

biocoenosis -_-__-

biotic realm, tropical -__-_

bivalve framework builders, rudist_________ 4,24

borneensis, Actaeonella_-_- $6,35,67,68 f, 76$; pls. 19, 20

Acteonella--_-_-_

Borneo -

Botijas Limestone Member, Pozas Formation,

Puerto Rico --

boutulliert, Trochactaeon

Trochactaeon (Neocylindrites) --_-_-_-_20, 54, 76

brandenbergensts, Trochactaeon (Trochactaeon)

lamarckl-_-__-_-_ 82,83

Brachydontes, association with Actaeonella sp. $-\ldots-24$

Brazil-_-_-_-_ 28f, 34

breils, Actaeonella (Trochactaeon)-_-_-_48, 56, 76, 77

Spiractaeon---_--_-_-_-_

briartl, Actaeonella -_-__-_- 76

Purpuractaeon -

Trochactaeon -

(Neocylindrites

briggsi, Actaeonella-_-_-35, 71, 72,72f,76; pls. 20, 21

brownt, Actaeonella -
Page

Buda Limestone, Texas, localities-____-_-_-_-_45 building corals - burckhardti, Actaeonella (Trochactaeon) - $47,58,76$ burckhardti, Actaeonella (Trochactaeon)___-_-47, 58, 76 Neotrochactaeon--.- Mexicotrochactaeon) - $34,58,59 f, 76$

Trochactaeon (Mexicotrochactaeon) $--34,58,59 f, 76$,
$80,81,82,84,85$, pls. 12,13

(Trochactaeon) - -

burrowing behavior, Actaeon and Actaeonella-_-_-_--5

\section{$\mathrm{C}$}

Cabo Rojo, Puerto Rico, collection localities --_--29f, 36 Caledonia Formation, Virgin Islands, _.____- 40

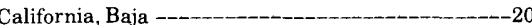

Bella Vista District -

Cenomanian distribution of Actaeonella--_-_---35

collection localities --_-_..-- $34 f, 46$ stratigraphic ranges of Western Hemisphere

species, index map - -

Callianassa-

Calliostoma - - - - -

Campanian time interval, through Maastrichtian -9, $10 f$

Caprina Limestone (Edwards Limestone), Texas ----45

Caprinuloidea rudist bivalve framework sequences,

Puerto Rico --_-_-

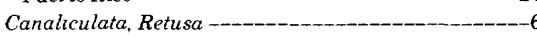

Cardenas Formation, Sar Luis Potosi, Mexico - - - 34,46

Caribbean region -_-_-_-_, 6, 10

Caribbean-Mexico region -_-_-_-_-_-_-_- 20

Cassidaria cretacea -_-_-_-_ 49,78

Cassis madagascarensis spinella-_-_-_-_-

catalogue, actaeonellid species -_-_-_-_-_- 74

caucasica, Actaeonella --_-

Actaeonella causica -_-_-_._-_

(Actaeonella)-_-_-_-_-_-_-_-_-_-_-_-_

(Pchelincevella) -

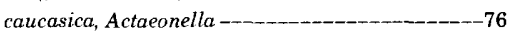

grossouvret, Actaeonella-__-_-_ $76,77,81,86$

shiosensis, Actaeonella-____-_ 77,85

styriaca, Actaeonella -_-_-_

zouparriensis, Actaeonella -_-__-_-_-_

caucasicus, Trochactaeon--_-_-_-_-_-_--

Trochactaeon (Trochactaeon) _-_________ 77

Cayey Quadrangle, Puerto Rico--_-_-_-_-_-_-29f, 35

Cenomanian distribution, Actaeonella -_-_-_-_ $9,10,35$

Central Aguirre Quadrangle, Puerto Rico-_-_-_-29f, 37

Central America, new actaeonellid finds -_-__._- 24

Central inlier, Jamaica, localities --_-_-_-_30f, 40-42

Chiapas (State of), Mexico -

choffati, Neotrochactaeon-_-_-_-_-_-_-_-_-

Trochactaeon --

(Trochactaeon) -

Coamo, Puerto Rico, localities --

abundance of Actaeonella coquiensis-_-___-35, 70 Coamo Quadrangle, Puerto Rico, localities-_-_-_-_-37 coatsı, Barrettıa - 34 collection localities, index maps -____-_-_ $29 f-34 f$ collgnoni, Actaeonella (Trochactaeon) --___-_-_--77

Trochactaeon --

Trochactaeon (Trochactaeon)-_-______- 77 columellar plaits --_-_-_-_-_-_-_-_-_ columellar retractor muscles-_____-_-_-_-_ communts, Trochactaeon

Trochactaeon (Trochactaeon)--_-_-_-_-_

Turritella -_-_-_-_-_-_-_-_-_-_-_-_-_-_-_ conform is, Actaeonella-_-_-_-__-_-_-_-_-_-_-_-_ conia, Trochactaeon Coniacian region of Mexico conica, Actaeonella Actaeonella(Trochactaeon) -_-_-_-_-_-_ 76,77 Tornata-1-_conicus, Purpuractaeon -_______ 49,77 Spiractaeon-Trochactaeon --_-_-_-_- 49,79

(Trochactaeon) -

Coniformis coniformis, Trochactaeon
(Mexicotrochactaeon) 
Actaeonella-____-_-_56, 57, 58, 62, 63, 85; pl. 16 Trochactaeon -- - $-48,56,77,84$

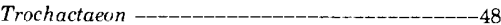
(Mexicutrochactaeon)-_-_-- $54,56,57,57 f, 58-60$ $62,75,76,81,83,84,86$ : pls. 10,1 con1formisconordea, Actaeonella Truchactaeon) -_-__-_-__-_-_-78 Mitra--_-_conotdeus, Trochactaeon (Trochactaeon)-_.......--_--78 Conus schiosensis-a coquiensis, Actaeonella --_----35, 70, 70f, 78; pls. 20, 21

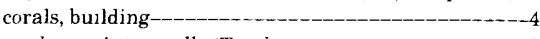
cordeiroi, Actaeunella (Trochactaeon)-_-_-_-_-_-_---78

Paleotruchactaeon --_-_-_-_-_-_-_-_-_-_-_-_--78

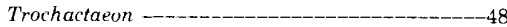

(Neocylindrttes)-_-_-_-_-_-_-_-_-_-_-_ 78.79

Corona, California, collection localities ---_-_-----46 correlations, formations--_----_-_-_-_-_-24, 25f, $26 \mathrm{f}$ Upper Cretaceous rocks---_-_-_-_-_-_-- $26 f, 27 f$ cossmanni, Trochactaeon--_-_-_-_-_-_---------80

Trochactaeon (Truchactaeon)-_-_-_-_-_-_-_-_-_--78 Cotu1 Limestone, Puerto Rico-_-_-_-26f, 34, 35, 38-39 crassa, Actaeonell--_-_-_-_-_-_-_Actaeonella -_-__._-_-_-_-_73, 77, 78, 81, 82, 89

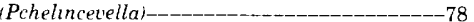
Volvaria -_-_-_-_-_-_-_-_-_-_-_-_-_-_-_-_-_--78 Volvulina ----_- 78 cretacea, Actaeunella --_-_-_-_-_-_-_-_-_-_-_--78 Cassidarta -___-_49.78

Cretaceous deposits, Caribbean Antilles and

Central America -

Cretaceous faunal assemblages, salinity ranges---_-- $8 f$ Cretaceous formations, correlation, Puerto Rico

and Texas --__-_-_-_-_-_-_-_-_-_

Cretaceous outcrop. Cuba------_-_--_-_--- $31 f$

Cretaceous rocks, correlation, Jama1ca - - - - $27 f, 30 f$ correlation, Puerto Rico --_--_-_._...-- $26 f$ Puerto Rico and Texas Cretaceous stratigraphic record -_-_-_-_-_---24 cretaceus, Purpuractaeon-----_Trochactaeon -crisminensis, Paleutrochactaeon --_-_-_-_-_-_8, 85

Trochactaeon --_-_-_-_-_-_-___-_._-_- 48,78 (Neocylindrites) --_-_-____-__-_-_ 54,78 Cuba, collection localities -----------31f, 35, 44-45 Stratigraphic ranges of Western Hemisphere

species --_-_-_-_-_-_-_-_-_-_-_-_-_- $28 \mathrm{f}$ cubensts, Actaeunella -9, 35, 65, 72,73f, 78; pls. 17, 22, 23 Cucullaea, bivalve --_-_. cumminsi, Trochactaeon -_....._-_ $53,56,78$ (Neocylindrites) $24,53,53 f, 55,56,78,83 ;$ pls. 4,9 cyclordeus, Trochactaeon-_-_-_-_-_-_ Trochactaeon (Trochactaeon)--_-_-_-_-_-_----78

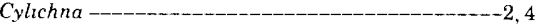

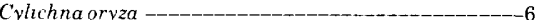

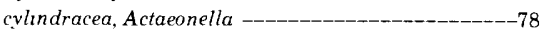
Actaeonella (Trochactaeon'--_-_-_-_-_--_---52,78 cylindraceus, Paleotrochactaeon --_-_-_-_-_-_-_

Trochactaeon --_-_-_-_-_-_-_-_-_-_-_-_-_48, 78 (Trochactaeon) --_-_-_-_-_-_-_-_-_-_ 52,78 cylindricus, Mesotrochactaeon-_-_-_-_-_-_-_-_-_ 78

Trochactaeon --_-_-_-__-_-_-_-_-_-_-_-_-_-_-78

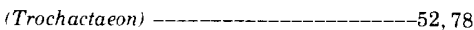

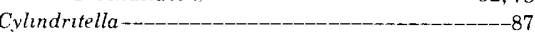
Cylindrttes, and Cretaceous Actaeonellidae---_-_---20 Cylindrites damest -_-_-__-_-__-_-_-_-_-_-_-_-_-_

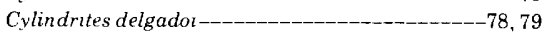

\section{D}

damesi, Cylindrites --_-_-_-_-_-_-_-_-_-_-_--

Trochactaeon -

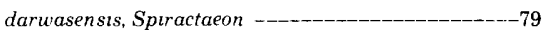

Trochactaeon --_-_-_-_-_ 83

(Trochactaeon) --_-_-_-_-_-_-_-_-_-_dating of formations, Texas vs. Antullear islands ---24 decorata, Actaeonella---------_--- 65.78

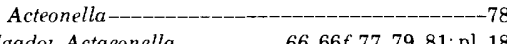

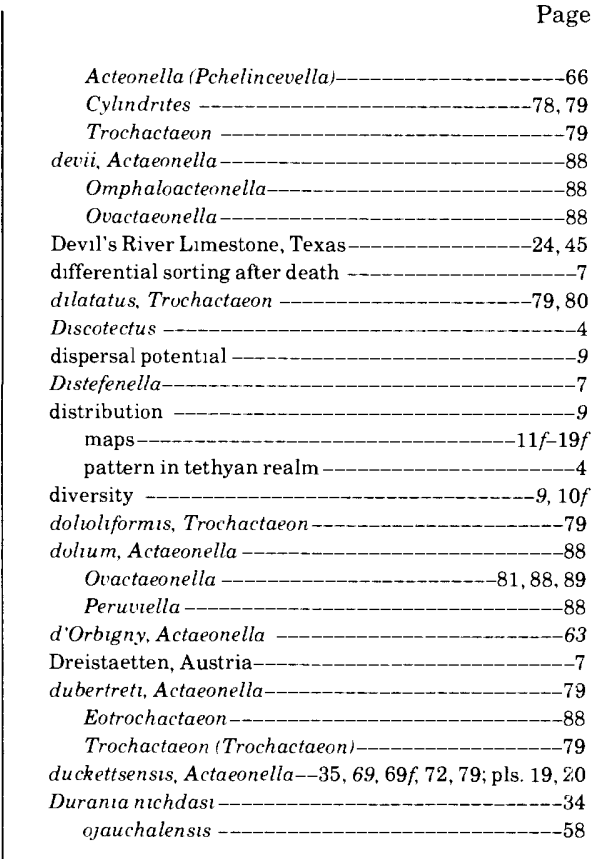

\section{E}

Early Cretaceous stratigraphic record --_-_-_-_-_-_4 early ontogeny --_--_. ecology -- Edwards Limestone (Capruna Limestone), Texas---_-45 ellipsoudes, Actaeonella --
Mesotrochactaeon Trochactaeun (Trochactaeon)-_-_-_-_-_-_-_-_-_-_79 Ellipsoscapha--_-_-_-_-_-_-_-_-_-_-_-_-_ elliptica, Actaeonella --_-_-_-_-_-_-_-_-_-_-_-_--79 ellipticus, Sptractaeon --_-_-_-_-_-_-_-_-_-_-_-79

Trochactaeon ---_-_-_-_-_--_-_-_-_-_--------79

(Trochactaeon) -_-_-__-_-_-_-__-_-_-_- 79 elongata, Actaeonella--------_--_--_-_-------70,79 El Rayo Formation, Puerto Rico --_-_-_---35, 38-40 Eotrochactaeon -_-_-_-____-_-_-_-_-_-_-_20, 85, 88 azerbaidjanensis -_-_-_-_-__-__-_-_-_ 88

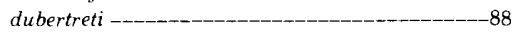

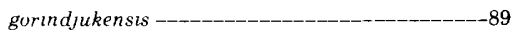
zumoffent -_-___._._._-_-_-_-_-_-_._-_ epifaunal life habit, Trochactaeon --_-_-_-_-_--_----5 Erath County, Texas -_-__-__

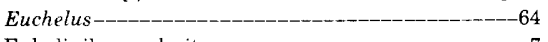

Euhalinikum salınity zone --_-_-_-_-_-_-_-_-_-_-7 evolution--_-_-_-_-_-_-_-_-_-_-_-_-_-_-_-_-_-_-_0 excelsus, Neotrochactaeon --_-_-___-_-_-_-_-_-_--79

Trochactaeon --_-_-_ 79,85

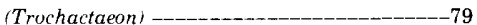

excluded genera and spec1es -_-_-_-_-_-_-_-_exhalant area ---------------------_---_-_----4 extinction --

parallels with other groups -_-____-__-__-_-_2

\section{F}

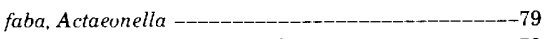
Actaeonella (Pchelincevella)_-__________-_79

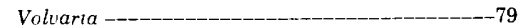
feeding habits--_-_-_-_-_-_-_-_-_-_-_-_-_-_-_-_-_ ferganica, Ovactaeonella --_-_-_-___-_-_-_-_64 ferjanica, Ovactaeunella-_-__-______-_-_-_-_-_-_-_8 Flor de Alba Limestone Lentil, Pozas Formation,

Puerto Rico - Florida Quadrangle, Puerto Rico --_-_-_---29f, 34, 37 floriformis, Tampsia -_-_-___-__-_-_-_-_-_-_----58 formations, correlations---_--_-_-_-_-----24, 25f, $26 f$ framework builders, rudist bivalve-_-_-_-_-_-_ 4,24 France, southern --_-_-_-_-_-_-_-_-_-_-_ frazterensis, Actaeonella --_-_-_-_-_-_-_-_-_ 50,79 Trochactaeon (Trochactaeon)---20,22, 50, 51, 79, 85: pl. 8

Frederıcksburg Group, Texas, localities-__fustformis, Actaeonella--_-_-_-_-_-_-_-_-_20, 22, 79

G

gagil, Actaeonella--__-_-_-_-_-_-_-_-_-_-_---88

Actaeonella (Sugdianella) --_-_-_-_-_-_-_-_88

Omphaloacteonella-_-_-_-_-_-_-_-_-__-_-_-_8

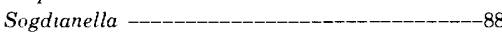

galloproutincialis, Trochactaeon (Trochactaeon) 59, 79, 80

Garumnien, of Spain --_-_-_-_-_-_-_-_-_-_-_20

genera excluded from Actaeonellidae

geographic distribution, Actaeonella and

Trochactaeon---_--_-_-_-_-_-_-_-_-19f, 20

georgica, Actaeonella --_-_-_-_-_-_-_-_-_-_-_----88 Acteonella-_-_- 88

gerthi, Peruvia --_-_-_-_--_-_-_-_-_-_--_-------88

Peruvella -_-_-_._.

ghazirensis, Actaeonella --_--_-_-_-_-_-_-_-_----80 Trochactaeon (Trochactaeon)--_-_-_-_-_-_-_-_--80 gigantea, Actaeonella-------------_-- - 79, 80, 85 Actaeonella (Trochactaeon)_-_-_--_---48, 58, 79, 80

(Trochactaeon) gigantea--_-_--_-_--_--- 80 gigantea, Actaeonella (Trochactaeon) ---_--_-----80 globusa, Actaeonella (Trochactaeon) --_---------80 Neotrochactaeon --_-_-_-_-_-_-_-_-_--80 subglobosa, Actaeonella (Trochactaeon) --_-_-----80 Tornatella--_-_-_-_-_-_-_-_-_-_-_-_-_-_---80

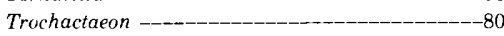
ventricosa, Actaeonella (Trochactaeon) ---_------80 giganteus, Actaenn-_-_-_-_-_-_-_-__-__-_-_-_ giganteus, Trochactaeon (Trochactaeon)-_-_-_--80 Neotrochactaeon -_-_-_-_-_-_ 79, 80 subglobosa, Trochactaeon (Trochactaeon)--------80 subglobosus, Trochactaeon (Trochactaeon) $-78,79,80$

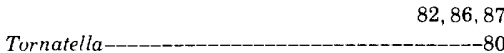
Trochactaeun --_-_-_-_-_-_-_-_-_-_-_-_----79, 80

(Trochactaeon) --_-_-_-_-_-_-_-_-_--_-_80,84

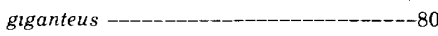
gigas, Barrettia--_-_-_-_-_-_-_-_-_-_-_-

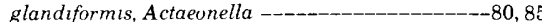

Neotrochactaeon--_-_-_-_- 80,85

Trochactaeon ---_------_--_-_-_-_-_-_-------80

(Trochactaeon) -_..._-_-_-_-_-_-_-_-_-_

Glauconia--_-_-_-_-_-_-_-_-_-_-_-_-_---_--_

Glen Rose Formation, Texas ---_-_-_-_-_-_-_-_----45

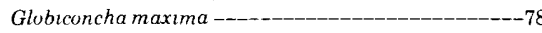

globosa, Actaeonella (Trochactaeon) gigantea--------80

goldfuss, Actaeonella -__._-_-_-_-_-_-_-_-_-_---80

Actaeonella (Trochactaeon) ------_--------80, 81

Trochactaeon --------------------- 80

(Trochactaeon)-_-_-_-_-_-_-_-- 77, 80, 81, 82, 86 gorindjukensis, Eotrochactaeon--_--_--_---_------89

Trochactaeon --_-_-_-_-_-_-_-_-_-_-_-_-_-_9

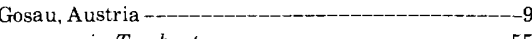

gosaunensis, Trochactaeon -...--_-_-_-_-_-----55

Trochactaeon (Nevcylindrites) --_-_-_-_-_-_--- 81 gracilts, Actaeonell--

(Pchelincevella)-_-_-_-__-_-_-_-_-_-_-_-_-_--78

Acteonella--.---_-_-

Truchactaeon -

gradatus, Trochactaeon-_-__-_-_-_-_-_

Trochactaeon (Neocylindrites)-_-_-_-_-_-_-_---81

grand $t s$. Actaeonella -_-_-_-_-_-_-_

Actaeonella (Sogdianella) --_---_--_-_------89

Acteonella (Sogdianella) --_-_-_-_-_-_-_----89

Sogdianella -___-_-_-_-_-_-_-_-_-_-_-_-_-_9 granthamensis, Trochactaeon (Mexicotrochactaeon) - -60 , $61,61 f, 63,81$; pls. 13,15

Green Island inlier, Jamaica --_-_-_ $64,76,77,79,81$

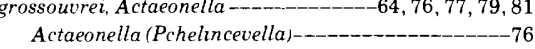

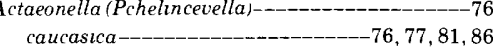

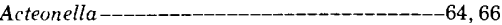




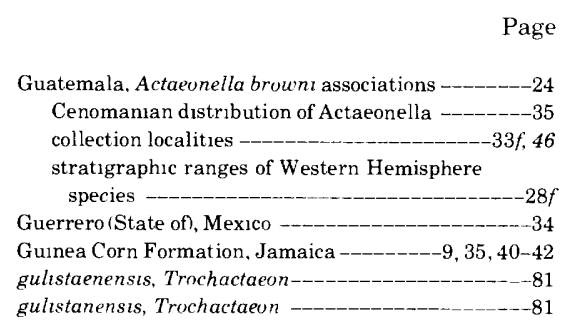

$\mathrm{H}$

Habana Formation, Cuba, localities -_-_-_-_-_-_44-45 habits, feeding --_-_-_-_-_--_-_-_-_-_-_---------6 head-foot mass, musculature ---------_Hispanola, new Actaeonellid finds ----_-_- 4 Humboldtt. Actaeonella (Trochactaeon) -_-_--58, 76,81 humel, Actaeonella (Trochactaeon) -___________-_-_ Trochactaeon (Trochactaeon)--_-_hydrocarbon resources, rudist bivalve framework structures -hypostracum crests

I

Idjevanensis. Palentrochactaeon ---------------81 Trochactaton (Trochactaeon)-------------------81 umpressus, Trochactaeon -____-_ 76,81 inconstans, Actaeonella Actaeonella ITrochactaeon)--_--_-----48, 56, 77,81

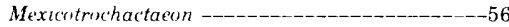

Indo-Pacific faunas, affinities with Western

Hemısphere gastropods -Inductura, partetal ---_-------------------------2

inflata. Actatinella -Actaeonella'Voliculina) --_-_-_-_-_-_-_-_-_-81 Infaunal life habit ----------_-----------_-----5 Inoceramus Shales, Jamarca --------_----_-_-_---35

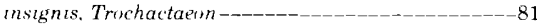
intermedius. Trochactaeon (Trochactaeoni---_------75 interplait muscle bands, function --_-_introduction trregularts. Actaemella ITrochactat'on) - $-48,56,77,81$ Mexicotrochactaeon -1somorphism, and environmental setings------------5

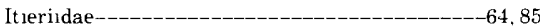

Jamarca, collection localities -__________-_-30f. 40-44 correlation of Upper Cretaceous rocks --_---27f, 30f stratıgraphic ranges, Western Hemisphere

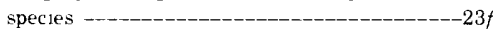
Jerusalem Mountain inlier -_-_-_-_-_-___-__-_-30f

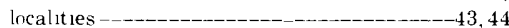

khalthin, Actaernella-_____-_-_-_-_-_-_-_-_-_-65 Actaeonella (Sogdianella) _.._........_. 89 Sogdianella -_-_-_-_-_-_-_-_-_-_-_-_-_-_-_-_89 Klamath River, Calıfornia -_-_-_-_-_-_6 kenstantiti, Actaernella - - -

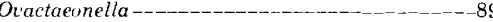

Koyokuk Rıver, Alaska --_--_-_-_-_-_-_-_-_-_-_-_---46 kuehnt, Truchactaeon (Trochactaeon) --_-_-_---80,81 kurdistanca. A ctaemella --_----_-_Actaeonella (Sigdianella) -.._-_
Page L

laevis, Actaeonella-_-_-_-_-_ 9, 64, 70, 72, 79, 81, 90 Actaeonella Volvulina) -____ laevis-.-_-_-_ $81,82,86$

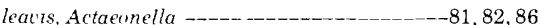
Volvarla -_-_-_-_-_-_ 84

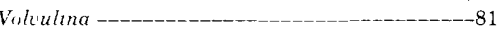
zekelu, Sugdranella -_-_-__-_-_-_-_-_-_-_-_ lagoonal associations -_-_-__-_-_-_-_-_-_-_-_-_-

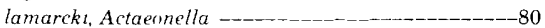
Actaemella (Truchactaeon) ....-..-----_--------82 Acternella--_-_-_--_-_-_-_-_-_-_-_-_--_82 brandenbergeasis, Truchactaeun (Truchactaeun) ---82,

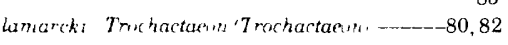
$85,86,87$ Spuractaeon-

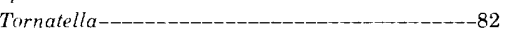
Trochactaeun --_-_-_._._. Truchactaeun)-_-_-_-_-_-_-_---80, 82, 85, 86, 87 Truchactaeon (Treshactaeon)-___________-_ 9,51 Truchactaeun +Truchactaeon) lamarckl----80, 82, 85 . 86,87 lamarcku, Turnatella-_-_-_-_ Late Cretacenus strat igraphic record --_-_-_-_-_---24 Late Cretaceous species having tubercles or nodes ---49 laticustata. S't'anella -_-_-_-_-_

Trichactaeon (Seranella)-_-_-_-__-___-_____-_-_ latus, Trichactaeon iTreichactaeon)-_-_-_-_--_----82 life mode and habits -----------------------4.5

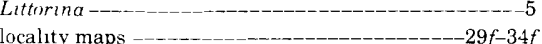
locality maps --
locality register $-\ldots-$ longa, Actaeonella --__longtsulcus. Mesotrochactaeon_.._-_-_-_-_-_82,85 Truchactaesm -

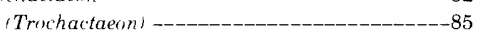
longitudinal gronves, Trochactaeon body whorl -.-..--2 Iuc'zana. Actae'snella-luctano. Actaeonella $-58,58 f .76,82$

\section{M}

Maastrichtıan species, Caribbean and middle America --_-_-_-_-_-_-_-_ 9 , 154 madagascarensıs spinella, Cassıs _-________........ 5 Magueyes Formation, Puerto Rico --_-_-_-- 24, 36 Maldon inlier, Jamaica, localitıes-_-_-_--_---_-_---44 Maldon Limestone, Jamaica, abundance of

Actaeunella coquiensis --_-_-_-_-_-_--_-_--_----70 localities --_-_-_-_- 44 occurrences of Actaeonella marchmontensis------35 mammilatus, Purpuractaeun-_-_-_-_-_-_-_-_-_-_-82 irnchactaeon (Trochactaeon) -_-_-_-_-_-_-_-_-_-_82 mantle edge, character

Maravillas Formation, Puerto Rico, localitıes $-35,37,38$ Marchmont inlier, Jamaica _-____...-9, 30f, 35, 42-43 marchmontensis, Actaeonella-- $35,71,71 f, 72,82 ; \mathrm{pl} .21$ mardakertensis. Actaeonella -----------------89 Ovactaeonella-

Martha's Vineyard. Massachussetts -- $20,24,35 ; \mathrm{pl} .22$ Massachusetts, localities-__-________________- 45 matensis, Actaeunella-Actaeonella (Trochactaeon) -_-__-_-_-_-_-_

Trochactaeon -_..._-_-_-_-_-_-_-_-_-_-_-- 79,82 (Truchactaenn)_-_..._-_-_-_22,51, 52, 79, 82 maxıma, Globiconcha--_-_-_-_-_-_-_, Mayaguez Formation, Puerto Rico --_-_- 24 Meımesohalinikum salınity zone -......-_-_-_-_-_-_- 7 melmensis, Truchactaeun (Mexicotrochactaeun) --63, 82; Melones Limestone, Puerto Rico - $\quad$ pls. 16,17 Mesutruchactaeon----_arnaudl--_-_-_-

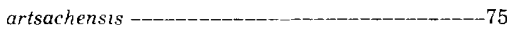
cylindricus - ellipsotdes -.._-__-__-__-__-_____-_-_ $82,83,85$
Page

longısulcus --_-_-_-_-_-_-_ 85

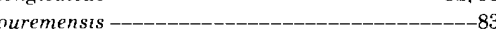
ovalts-_______._. subglobosa --_-_-_-_-_-_-_-_-_-_-_-_-------80 toousensis --_-_-_-_-_-_-_-_-_-_-_-_-_----85, 86

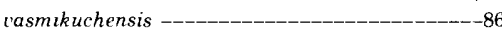
Mexico, collection localities -..._-_-_33f, 34, 35, 45-46 nerineid gastropods -_-_-_-_-_-_-_-_-_-_-_-_-_--24 new actaeonellid finds - - occurrences of Actaeonella borneensis -----------35 stratigraphic ranges, Western Hemisphere$$
\text { species }
$$

acutıssıma--_-_-_-_-_-_-_-_-_-_-_-_-_-_-_56, 77 inconstans--_-_-

irregularts-_-_-_-_-_-_-_-_-_-_-_-_-_-_-_-_56,77 planilateralis --_-_-_-_-_-_-_-_-_._-_ 77

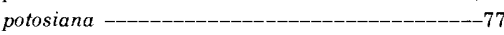
potosianusvartabults--

(Mexicotrochactaeon) burckhardt, Trochactaeon--34, 58 , $59 f, 76,80,81,82,84,85 ;$ pls. 12,13 coniformis, Trochactaeon --54,56,57,57f,58,62,75, $76,81,83,84,86$; pls. 10,11

coniformis, Trochactaeongranthamensts. Trochactaeon -_--60,61, 61f, 63,81; pls. 13,15 melenensts, Trochactaeon ______-_63, 82; pls. 16, 17 nelsoni, Trochactaeun --_-_-_-_-_-_-_-_-_-_---82 palmerl, Truchactaeun -...--60,60f, 83; pls. 11, 14 rossi, Trochactaeon ----57,60,62, 62f, 85; pls. 13.16 teaensts, Truchactaeon-_-__-_-_--60, 86; pls. 13, 14 Trochactaeon ------------------ $9,47,48,68 ; \mathrm{pl} .3$ spp. - - uright , Truchactaeon -___-_59, 59f, 60, 87; pls. 11,12 minutis, Trochactaeun (Nevcylindrites)-_-_-_-_-_-_-82 minutus, Trochactaeon ---_---_--_-_---_--_-----82 mirabilis, Trochactaeun-_-_-_-_-_-_-_-_-_----82

Trochactaeun (Trochactaeon)-_-_-_-_-_-_-_------82 Mitra conotdea --_-_-_-_-_-_-_-_-_-_-_-_ Mojado Formation, New Mexico, age -____-_-_-_--56 monll fera, Barrettia --_-_-_-_-_-_-_-_-_-----34 Morelos (State of, Mexico, localities -_-_-_-_-_-_-_-_-_46 morphology, features ------------------_---------3f interspecific variability --_--_-_--_-_-_-_--_----48 muscle bands, interplait ---------------------4 muscles, columellar retractor -_-_-_-_-__-_-_-_-_-_2 musculature, head-foot mass

Naticidae, effect on food chains ---_-_-_-_-_-_--22 nelsont, Truchactaeun (Mexicotrochactaeon)-_-_-_-_--82 Trochactaeon (Neocylindrites) -_____-20, 34, 55, 55f: pls. 8,11

Neocylindrites--_-_-_-_- 20,48 characteristic features-_-_-_-_-_-_-_-_-_-_-_-_-- 54

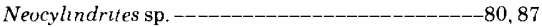

(Neocylindrites) abbreviatus, Trochactaeon --_-_-- 75 absalonts, Trochactaeon---_---_---_--------75 angustatus, Trochactaeon ------_--_------_---75 bacunicus, Trochactaeon --_-_-_-_-_-_-_-_---75 barremicus, Trochactaeon -_____-_20,48,54,75 baylet, Trochactaeon -belgicus, Trochactaeon--_-_-_-_-_-_-_-_-_-_---76 boutzllert, Trochactaeon -_-_-_-_20,54,76 briart, Trochactaeon --_-_-_-_-_-_ 54,76 curdeirol, Truchactaeon

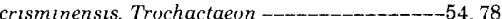
cumminsi, Trochactaeon---24, 53, 53f, 55, 56, 78, 83; pls. 4,9 gosaviensts, Trochactaeon---------__-

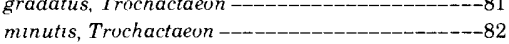
minutis, Truchactaeon-_-_---_0,
nelsoni, Truchactaeon --_---20, $35,55 f ;$ pls. 8,11 olviformts, Truchactaeon --_-_-_-_-_-_-_-_---_83 parcus, Trochactaeon--_-__-_-_-_-__-__-_-_-_54 
punctatus, Trochactaeon -_-_-_20.54,55, 58,59, 77 , 83,$84 ;$ pls. 4,9 Trochactaeon--_-_-_-_-_-_-_ 22, 34, 47 sp. - - sp. A -- sp. B --_-_-_-_-_-_-_-_-_-_-_-_-_56, 87; pl. 8 ventricosa, Trochactaeon -_________-_

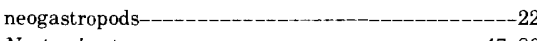

Neotrochactaeon -_-______-_ 47,80 burckhardtl --_-_-_-_-_-

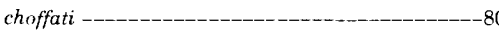

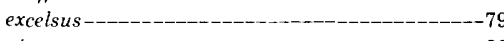

gigantea --_---_-_--_-_-_-_-_-_-_-_-_-_---_---80

giganteus ---_-_-_-_-_-_-_-_-_-_-_-_ 79,80 glandiformis - ventricosa - _ ventricosus --_-_-_-_-_-_-_-_-_-_-_-_-_-_------80

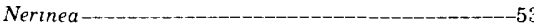

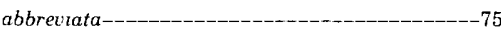
bicincta-_-_-_-_-_-_-_-_-_-_-_-_-_-_-_-_-_-_4

Nerineacea, Iteirdae-_-_-_-_-_-_______-_-_-_-_-_-_64

nerineid-dominated shale and limestone,

Puerto Rico --_-_-_-

Neritopsis, association in shales with Trochactaeon -..-7

New Mexico, collection localities -_-____-_-_-32f, 45, 56 stratigraphic ranges, Western Hemisphere

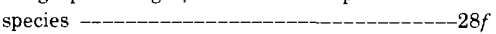

Nohatatietin, Yukon, Alaska --_-_-_-_-_-_-_-_-_-_46 nicholast, Durania -_.._-_._-_-_-_-_-_-_-_-_-_

Nuevo beds, State of Chiapas, Mexico-_-_-_-_-_-_-_-_6

\section{$\mathrm{O}$}

obesus, Trochactaeon Trochactaen (Trochactaeon)-----_-_-_-_-_------82 obliquecostata, Actaeonella -______________ 81.82 obliquepltcatus, Trochactaeon-_-_-_-_-_-_------76, 81 ubtusa, Actaeonella ---_-_-_-_-_-_-_-_-_-_--_83

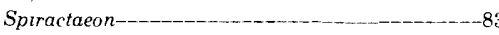
Trochactaeon (Trochactaeon)---_-_-_-_-_-_--_-83

obtusus, Spiractaeon -_-_-_-_ 89 Trochactaeon (Trochactaeon)-----_-_-_-_-_-_--63 occidentalis, Actaeonella --_----_---_-_--_--_58

Actaeonella (Trochactaeon)--_-_-_----48, 56, 77, 83 Ocuilapa, State of Chiapas, Mexıco, localities ------- 45 occurrences in Western Hemisphere--_-__-_-_-_-_-_22 ojauchalensis, Duranıa --_-_-_-_-_-_-_-_-_--_--_34 olvaeformis, Actaeonella-_-_-_-_-_-_-_-_-_-_-_-_--_83 oliviformus, Actaemnella -_._-___-_-_-_-_-_-_-_-_-20, 83

Trochactaeon --_-_-_-__-_-_-_-_-_-_..... 83 (Neocyllndrites) ---_-_--_-_-_-_-_-_-_-_-_--83

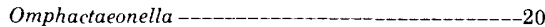

Omphacteonella ovata ----_-_--_-_-_--_-_-_-_-- 89

Omphaloactaeonella-_-_-_-_-_-_, 88

azerbaidyanica - -

Omphaloacteonella agjakendensis --_--_-_-_-_-_-_--88

anchietal-_-___-_

devu - ...

gagil -_-_..........

ovata -.--.----

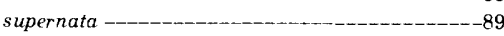

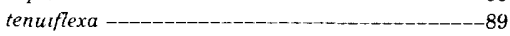

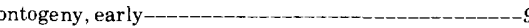

Orange County, California …............

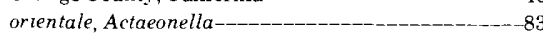

Oriente Province, Cuba, exclusive occurrences - - ----35

ornata, Actaeonella---_-------_---_-_-_-_-_-_---65, 83

Actaeonella (Pchelinsetiella)-_______________ 83

ornatus, Paleotrochactaeon ---_--_-_-_-_-_-_-_83

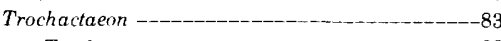

(Trochactaeon) -

Orocovis, Puerto Rico --_-_-_-_-_-_-_--29f, 34. 37-38

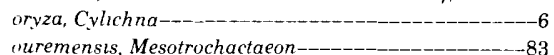
(ruremensis, Mesotrochactaeon---_--_-_-_-_-_-_-83

Ovactaeonella -___- 64,88 agdjakendensis-- -

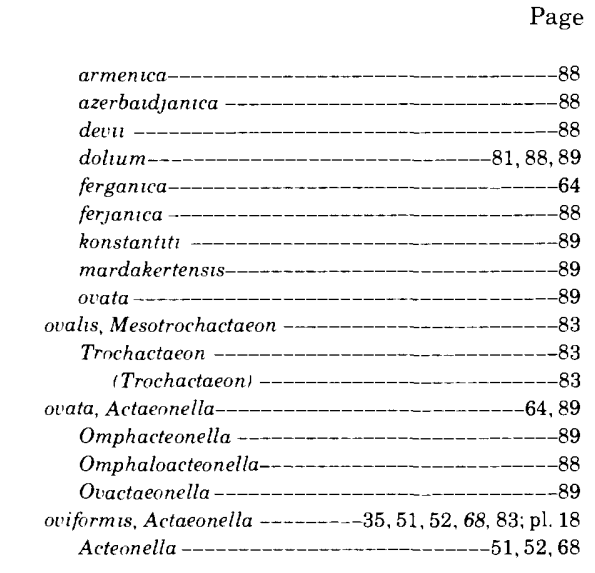

\section{$\mathrm{P}$}

packardl, Actaeonella-_-_-_-_-_-_-__-_-_-_-_-- 51, 83

Trochactaeon (Trochactaeon)-_-_-20, 22, 51,52,52f, 68,$83 ;$ pl. 8

Paleotrochactaeon -angustatus -_-_-_._._._-

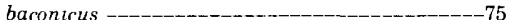

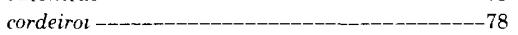

crisminensis --_--_-_-_-_-_-_-_-_-_--_-- 78,85

cylindraceus --_----_-_-_-_-_-_-_-_-_-_-_--.-----78

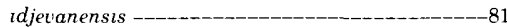

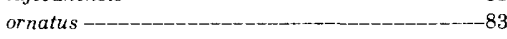

Palmarejo, Puerto Rico-_.___._.........29f, 34

palmerl, Trochactaesn (Mexicotrochactaeon)-60, 60f, 83: pls. 11,14

pamircum, Trochactaeon ---------_---------83 parietal inductura --_---_---_-_-_-_-_---_-----2

parva, Actaeonella -_-_-_-_-_-_-_-_-_-_-_-_-_-_-_-83

Actaeonella (Trochactaeon) -..._-_-_-_-_-_-_

Trochactaeon (Trochactaeon)-----_---_-_---83

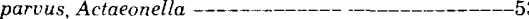

Actaeonella (Trochactaeon) --_-_-__-_-_

Trochactaeon -...---_-_-_-_-_-_-_-_-_53, 54, 83

(Neocylindrites) --------------_----------54

patagonica, Actaeonella -............_-_-_-_-_-_-_83

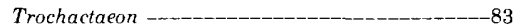

\section{Patella}

pcelinsev, Purpuractaeon ----_-_-_-_._-_-_-_-----84

pcelensev, Trochactaeon (Trochactaeon)_____49,50,84

Pchelincevella--_-_-_-_-_-_-_-_-_._-_._-_

(Pchelincevella) caucastca, Actaeonella--_-_-_-_-_-76

crassa, Actaeonella-----_----_-_-_-_--

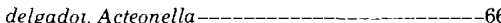

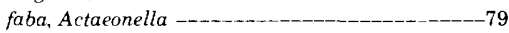

gractlss, Actaeonella-_-_-_-_-_-_-_-_-_-_-_-_-_-_8

grossouvrei, Actaeonella --_-_-_._-_-

pchelincev', Actaeonella_-_____________________-_84

schiosensts, Actaeonella-_-_-_-_-_-_-_ 77.85

styriaca, Actaeonella -_-_-_._._-_-_-_-_-_-_-_

terterensts, Actaeonella -_-_-_-_-_-_-_-_-_-_-_86

Acteonella-_-_-_- 6

zouparriensis, Actaeonella--_-_-_-_-_-_-_----77

(Pchelinsevella) ornata, Actaeonella --_-_.--_---83

praecaucasica, Actaeonella --_-_-_-__-_-_-_-_-_-84

(Pchelintsevella) sublaevis, Actaeonella-_-_-__-_--85

pchelincevi, Actaeonella-----_-_-_-_-_-_-_-_-_-_4

Actaeonella (Pchelincevella)--_-_-_-_-_-_---84

peconsensis, Actaeonella -_._-_._-_-_-_-_-_-_-35,65

pecosensts, Actaeonella------65, 65f, 66, 84; pls. 18, 20

Pedalion, bivalve --_-

Peruc'va gerthi----_-_-_-_-_-_-_-_-_-_-_-_

Sogdianella ---

Peruviella-------_.-- 88

dolum -

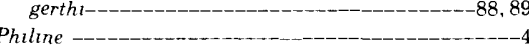

phylogeny ---_--_- $20,21 \mathrm{f}$

proposed -_-_-__n_
Page

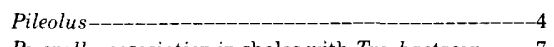

Ptrenella, association in shales with Trochactaeon ----7

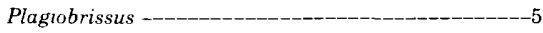

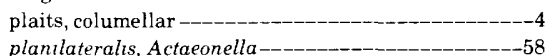

Actaeonella (Trochactaeon)-----48, 54, 56, 77, 78, 84

Mexicutrochactaeon -

Mexicutrochactaeon -
plate-tectonic theory --

Pleiomesohalinikum salınıty zone --_-_--_------

Polyhalinikum salinity zone -_-_-_-__-_-_-_-_-_-_-_-_7

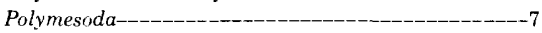

polymorphism, and environmental setings --_-_-_--5

pompet, Actaeonella--_-_-_._-_-_ 58, 58f, 59, 76, 84

Pondoland, South Africa ------_-_-_-_-_-_-_-_---20

posterior aperture margin---_-_-_-_-_-_-_-_-_

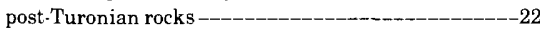

potosiana, Actaeonella (Trochactaeon)-_-_- $48,56,77,84$

Mexicotrochactaeon -

potestanus, Mexicotrochactaeon-_-_--_-_-_-_----56

Pozas Formation, Puerto Rico -_-_-_-_34, 36, 37-38

praecaucastca, Actaeonella -_-_-_-_-__-_-_-_-_-_84

Actaeonella (Pchelinsevella)-_-___-__-__-_-_-_84

praesulcata, Actaeonella --_-_-_-_-_-_-_-_--_-_-84

praesupernata, Actaeonella -_-_-______-_-_-_

Actaeonella'Sogdianella) --_-_-_-_-_-_-_ 89

Sogdıanella ---_--_-_-_-_-_-_-_-_-_

prisca, Actaeonella i Trochactaeon) --_..-_-_---_---84

projectiliformis, Trochactaeon (Trochactaeon) --_----84

protoconch character, size -...-_-_-_-_-_-_-_-_-----9

pruniformis, Actaeonella (Trochactaeon $--------58,84$

Trochactaeon--_-_-_-_ 84, 85, 86

pseudocylindraceus, Trochactaeon --_-_-_-_-_-_ 84

Trochactaeon (Trochactaeon)-_-_______-_22,52,84

Pseudomelanı-_-_-_-_-_-_-_-_-_-_-_-_-_-_-_

Ptychocylindrttes --_-_- 20

Puerto Real Quadrangle, Puerto Rico, localities--29f, 38

collection localities -___

Puerto Rico, correlations of Cretaceous rocks----25f, $26 f$

occurrences, actaeonellids -

Trochactaeon (Trochactaeon) woodst---

stratigraphic ranges, Western Hemisphere

species ----_----_----------_------------25f

punctata. Actaeonella (Trochactaeon) acutissima ----54,

$56,58,77,84$

subspecies --__-_.

punctatus, Trochactaeon (Neocyltndrites)-----20,54,55,

$58,59,77,83,84 ;$ pls. 4,9

Purpuractaeon -- -

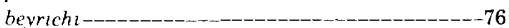

briarti--_-_._.

conicus - c.-_-_-_-_-

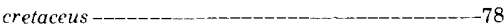

mammilatus -..--------_-

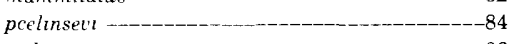

vediensts-___

\section{Q}

quadratus, Trochactaeon---_-_-_-_-_-_ 84 quadriplucata, Actaeonella (Truchactaeon) ----58, 76, 84 quadriplicatus, Actaeonella (Trochactaeon\}--_------47

$\mathrm{R}$

Radioltes-Trochactaeon group--_-_-__-__-__-_-_-6 radiolitid curvature Rancho Nuevo Beds, State of Chiapas, Mexico----35, 46 ranges, stratıgraphic, Western Hemisphere -_-_-_-_-28f Raritan Formation, Massachusetts--_-_references cited --_-_- 90 reflections of soft parts on shell --_-_--_-_-_-_-_---2 reguearts, Trochactaeon--_--_-.-_-_-_-_-_---79, 84 Trochactacon Trochactaeon/-_____________-_84 Remane's salınity zones------_-_-_-_-_-_-_----- 7 renauxiana, Actaeonella-.-_-_-_-_-_-_-_4, 80, 84, 85 Actaeunella (Tro'hactaeon) --_-_-_-_-_-_-_-_84, 85 Trochactaeon --_-_-_-_-_-_-_-_-_-_---_84 renauxianus, Trochactaeon --_-_-

Trochactaeon \{Trochactaern \}--_-_-_-______-_-84 
Page

repelint, Actaeonella--_-_-_--_-

Vernedia--

resorption phenomena -_-_-_-_-_-_._-_-_-_-_-_-_--_5

retractor muscles, columellar - _-______._.

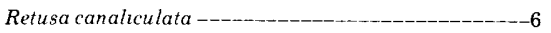

Reves Member, Pozas Formation, Puerto Rico -34, 35-36

Rimella------

Rio Bauta Member, Pozas Formation, Puerto

Rico --

Rio Descalabrado Quadrangle, Puerto Rico------29f, 38

R1o Maton Limestone Member, Robles Formation.

Puerto Rico -_-_-_-_-_-_-_-_-_-_-_-_

Rin Minho, Central inlier, Jamaica-_-

roashensts, Actaeonella--------_--_-_-_--_-_84

Actaeonella Actaeonellai-_.___-__-___-____-_84 robinsoni, Actaeonella-----35, 65, 69, 72, 73, 84; pls. 17.

22,23

Robles Formation, Puerto R1co _-_ robustus, Trochactaeon --_-_-_-_-_-_-_-_..._-_-_84 Rocky Gulch, Siskiyou County, California -_____ 46 rossi. Trochactaeon (Mexicotrochactaeon)-----57, 60, 62, $62 f, 85 ;$ pls. 13,16

rotundata, Actaeonella-_-_-_-_-_-_-__-_-_rudist bivalve framework bulders --_---_-_---- 4,24

biostratigraphy _-.... $24,25 f, 26 f$ rugosus, Trochactaeon -..-_-_-_-_-_-_-__-_-_-_-_5

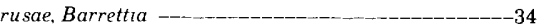
rustica, Actaeonela-___-_-_-_-_-_ 79, 85

S

Sabana Grande Formation, Puerto Rico-_-_______-_39 Sabana Hoyos Limestone Member, Maravillas

Formation, Puerto Rico-_-_-_-_-_-_-_-_----38 St. Ann's Great River inlier, Jamaica _._. $9 f$ f. 38, 39, 44 salınity ranges, Cretaceous faunal assemblages-------8f salinity tolerance----_-_---_---_---_-_-_-_-_salinity zones, Remane's -____-_-_-_-_-_-_-_-____-_salomonis, Actaeonella--_-__-_-_-_-_-_-_-_____-85 Actaeonella (Troshactaenn) --__-____ 82,85

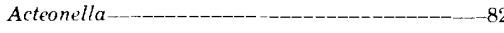

Trochactaeon --_-_-_-_-_-_-_-_-___-_-_-_-_ Truchactaeon -_-_-_-_____-_-__-_-_-___-_-_85 Sanctae-Crucis, Actaeonella --_-_-_-_-_-_-_-_- 85 sanctaecrucis, Trochactaeon (Trochactaeon) -----59, 80 ,

84,85

San German Quadrangle, Puerto Rico --_-_-----38-40 San Luis Potosı (State of), Mexico --------34, 35, 46, 58 scalata, Voluta --__-_..-_-_-_-_-_-_-_-_-_-_-_-_- 85

scalatus, Trochactaeon (Trochactaeon) --_-_-_-_--_--85 Scaphander --_-_-_-_-_schiosensts, Actaeonella--_-_-_-_-_-_-_-_-_-_-_7, 85 Actaeonella (Pchelincevella)_-_________-_77,85 (Voluulina) -_-__-__-____-_-_-_-_-_-_-_77, 85 caucasica-_-_-_-_-_-_-_-_--_-_-_--_--77,85

Conus - -

Trochactaeon --_-_-_-_-_-_-_-_ schirabadensts, Spriactaeon --_-_-_-_-_-_-_-_-_-_--85

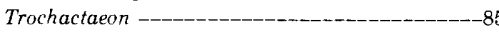
(Trochactaeon) --_-_-_-_-_-_-_-_-_-_-_-_ 85 secondary lamellae --_-_-_-_-_-_-_-_-_-_-_-_----5 sergipensis, Trochactaeon --_-_-_-_-_-_-_-_-_-_-_88, 89 Sevanella -_._-_-_._-_._-

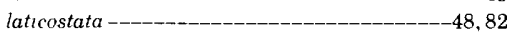
tuberculata--_-_-_-_-_-_-_-_-_-_-_-_-_----_----86

(Sevanella) laticostata, Trochactaeon --_-_-_-_-_---82 Trochactaeon---_---_-_-_-_-_-_-_20, 22,47,48 tuberculatus, Trochactaeon --_-_-_--_-_-_-_--86

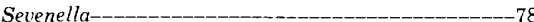

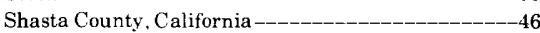
shell character, and life habit-_-_-_-_-_-_-_-_, 5 shell morphology shell, reflection of soft parts--_-_..._._._._-_-_-_-_-_-_ Sierra Rica, New Mexico --_-_-_-_-_-_-_-_-_-_--56 silvae, Actaeonella --_-_-_-_-_-_-_-_-_-_--_--_--_85 similis, Trochactaenn--_-_-_-_-_----------------85

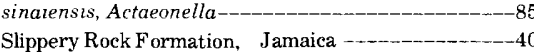

Page

soft parts, reflections on shell --_-_-_-_-_-_-_-_-_-_-

Sogdianella-_-_-_-_-_-_-_-_-_-_-_-_-_-_-_-_64, 88

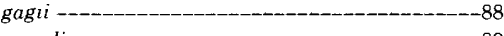

grandis -_-_-_-_-_-_-_- 89

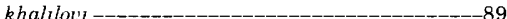

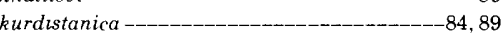

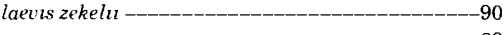

peruviana -..--_------------------_------89

praesupernata-_-_-_-_-_-_-_-_-_-_-__-_-_-_-_-_-89

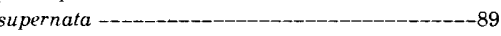

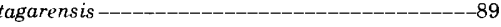

tenuiflexa -_-__-_-_-_-_-_-_-_-_-_-_-_-_-_-_-_89

(Sogdianella) gagu, Actaeonella --_-_-_-_-_-_-_---88

grandts, Actaeonella --------_-_-_-_-_-_-----89

Acteonella-_-_-_-_-_-_-_-_-_-_-_-_-_-_-_ 89

khalilov', Actaeonella-_-_-_-__-_-__-_-_-_-_---89

kurdistanica, Actaeonella --_-_-_-_-_-_-_-_-_89

praesupernata, Actaeonella --_-_-_-_-_--89

supernata, Actaeonella--_-_-----_--_---------89

Acteonella-_-_-_-_-_-_-_-_-_-_-_-_-_-_-_89

tagarensis, Actaeonella --_-_--_-_-_-_-_-_--_-89

tenuiflexa, Actaeonella-____-_-_-_-_-_-_-_-_9

zekelu. Actaeonella-_-_-_-_-_-_-_-_-_-_-_-_-_-_90

solidus, Trochactaeon --_-_-_-_-_-_-_-_-_---------85

Trochactaeon (Trochactaeon)-----------_------85

sorting, differential, after death ---_---_--_-_---_-_--7

South Fork Cow Creek. Shasta County, Californı-----46

Spain, Garumnien --_-_-_-_-_-_-_-_-_-_-_-_-20

species assigned to Actaeonellidae ---_------_---74-86

species diversity during Cretaceous-_-_-_-_- $10 f$

species excluded from Actaeonellidae-_-__-_-_-_-87-90

speciosus, Trochactaeon-_-_-_-_-_-_-_-_-_-_-_-_-_85

Trochactaeon (Trochactaeon)--_-_-_-_-_-_-_-_--85

spinella, Cassis madagascarensis --_-_-_-_-_-_----5

Sphenodiscus sp. ---_-_-_-_-_-_-_-_-_-_-_-_-_-_--34

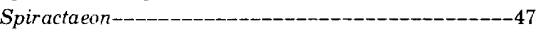

brevis --

conicus --_-_-_-_-_-_-_-_-_-_-_-_-_-_-_-_-_-_-_77

darwasensıs --_-_-_-_-_-_-_-_-_-_-_-_-_

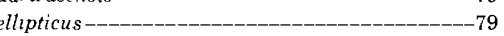

lamarcki---_--_-_-_-_-

obtusa -_-_-_-_-_-_-_-_-_-_-_-_-_-_-_-_-_-_-_83

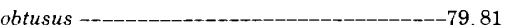

schirabadensis --_-_-_-_-_-_- 85

"ariospiralis -_._._-_-_-_-_-_-_-_-_-_-_-_-_--_86

SSR, Armenian -_-_-_-_-_-_-_-_-_-_-_-_-_-_-_---22

stabilis, Trochactaeon -_-_-_-_-_-_-_-_-_-_-_-_

Stapleton Formation, Jamaica --_-_-_--35, 44, 70

Stinking Canyon, Shasta County, California---------46

Stoliczka, Voluulina--

stratigraphy, Western Hemisphere species, ranges --28f

summary - -

styriaca, Actaeonella (Pchelincevella) -_-_---_-----77

Actaponella caucasica______ 77,81

subangustatus, Actaeonella (Trochactaeon) --_-_----78

Trochactaeon ------- 78,85

subburckhardti, Trochactaeon-------------------85

subglandiformus, Trochactaeon-_-_-_-_-_-_ 80,85

subglobosa, Actaeonella--_-_-_-_-_-_-_-_--_----80

Actaeonella (Trochactaeon) gigantea-------------80

Mesotrochactaeon-_-_....--_-_-_-_-_-_--80

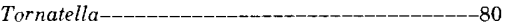

Trochactaeon (Trochactaeon) giganteus -_--_-_-_-80

subglobosus, Trochactaeon ---------------------80

Trochactaeon (Trochactaeon) giganteus ---78, 79, 80 .

$82,86,87$

sublaevis, Actaeonella -........._-_-_-_-_66, 67,85

Actaeonella (Pchelintsevella) -.--_-_-_-_

(Voltaria) -.....__ 66.85

subobtusus, Trochactaeon --_-_-_-_-_-_-_-_-_-_-_-79

subutusus, Trochactaeon --_-_-_-_-_-_-_-_-_-_-_-_-85

subovatus, Trochactaeon --_-_______- 80,85

subpruneformes, Trochactaeon--_-_-_-_-_-_-_-_---_86

Trochactaeun (Trochactaeon)-_-_-_-_-_-_-_-_-_-_86

subrenauxi, Trochactaeon ------_--_---_---------86

Trochactaeon (Truchactaeon)--_-_-_-_-_-_----_-86

substrate preference -_-_-_-_-_-_-_-_-_-_-_-_6

Sunderland inlier, Jamaica - _

supernata, Actaeonella--_-_-_-_-_ 64
Page

Actaeonella (Sogdianella) --_-----_-----------89

Acteonella--_-_-_-_-_-_-_-_-_-_-_-_-_-_-_---89

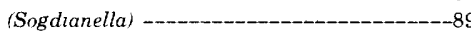

Omphaloacteonella--_-_-_-_-_-_-_-_-_-_--_---89

Sogdianella -

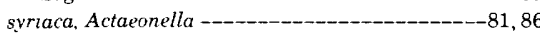

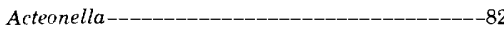

systematic paleontology --_-_-_-_-_-_-_-_-_-_-_---46

szontaghi, Actaeonella--------_-_-_-_-_-_---86

Trochactaeon (Trochactaeon)--------_--_------_86

$\mathrm{T}$

tagarensis, Actaeonella -

Actaeonella (Sogdtanella) _-______________-_-_

Sogdianella -_-__-__-_-__-_-_-__-__-_-_-_-_89

tamanderensis, Actaeonella-_-_-_-_-_-_-_-_

Tampsia floriformus zone, Mexico --_-_-_-_-_-_58

teqensis, Actaeonella --_-_-_-_-_-_-_-_-_..._-_-_68

Trochactaeon (Mexicotrochactaeon)-60, 86; pls. 13, 14

Tellina, bivalve -

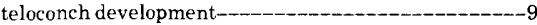

tenuflexa. Actaeonella-_-_-_-_-_-_-_-_-_-_-_-_

Actaeonella (Sogdranella) -_-_-_-_-_-__-_-_-_89

Omphaloacteonella--_-_-_-_- 89

Sogdianella --_-_--_-_-_-_-_-_-_-_-_-_-_-_---89

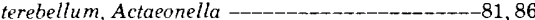

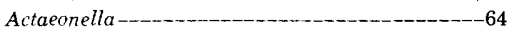

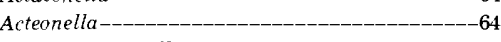

terterensis, Actaeonella -.--_-_-_-_-_-----86

Actaeonella (Pchelincevella)_-_..._-_-_-_-_-_-86

Acteonella (Pchelincevella)-_-_-_-_-_-_-_-_-_---86

Tethyan biogeographic province --_-_-_-_-

faunal associations-_-_-_-_-_-_-_-_-_-_-_-_-_-_-_4

texana, Volvulina--_--_-_-_-_-_-_-_-_-_-_-----88

Texas, Cenomanean distribution of Actaeonella -----35

collection localities ------------------- $32 f, 45$

correlation of Middle Cretaceous formations---- $25 f$

dating of formations

stratigraphic ranges, Western Hemispheric species -

Thorp Springs Limestone Member, Glen Rose

Formation, Texas -_-_-_-_-_-_-_-_-_-_-_

time intervals, occurrences of species --_---_---- 9

division of date --_--_-_--- $9,10 f$

Titannsarcoltes limestone, Jamaica --_--- 9, 35, 42-44

tolerance, salinity --_-_-_-_-_-_-_-_-_-_-_-_-_-_-_-_-7

Tornata conica --.---_-------------------------77

Tornatella conica ---_-_-_-_-_-_-_-_-_-_-_-_-- 77

gigantea --- --

giganteus --_-_-_-_-_-_-_-_-_-_-_-_-_-_-_-_-_

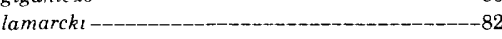

lamarckir --_--_-_-_-_-_-_-_-_-_-_ 80,82

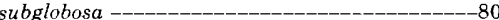

tornatilis, Actaeon --_-_-_-_-_-_-_-_-_-_-_-_-_--_2

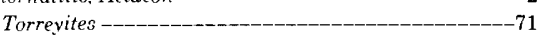

torrubial, Actaeonella -_-_-_-_-_-_-_-_-_-_-_-_-_-_86

toucasiana, Actaeonella--_-_-_-_-_-_-_-_-_-_-----80, 86

tovusensis, Mesotrochactaeon--_-_-_-_-_-_-_---85, 86

Trochactaeon (Trochactaeon)--------------79, 86

Trajanella------------------------_--_---------4, 24

- 10,20

transyltantcus, Trochactaeon --_---_--_--_------80, 86

Trichonopoly area, southern India --_-_-_-_-_--20

Trochactaeon -----_-_-_----7, 9, 46, 68, 83; pls. 3-16

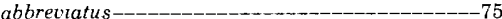
absalonts--_-_-_-_-_-_-_-_-_-_-_-_-_-_-_-_

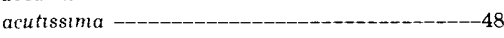

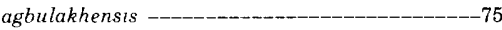

alsbeglyensis--_-_-_-_-_-_-_-_-_-__-_-_-_-- 75 angustatus --_-_-_--_-_-_-_-_-_-_-_-_-_--48,75 armenicus---_arnaudt--_-_-_-_-_-_-_-_-_-_-_-_-_-_-_----75

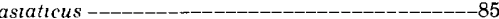
associations --_-_-_-_-_-_-_-_-_-_-_-_-_-_-_-_-6

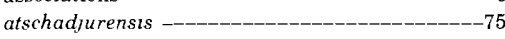
azerbatdjanensis -__......_-_-_-_-_-_-_-_ babkovt---_-_-_-_-______-_-_-_-_-_-_-_-_-_-_5 baconicus -_-_-_-___......_. 


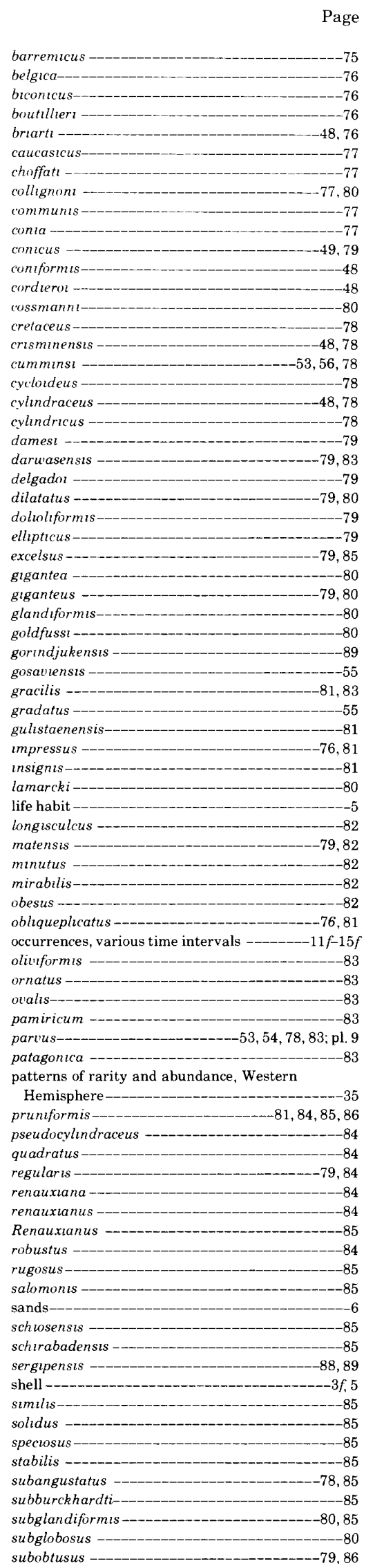

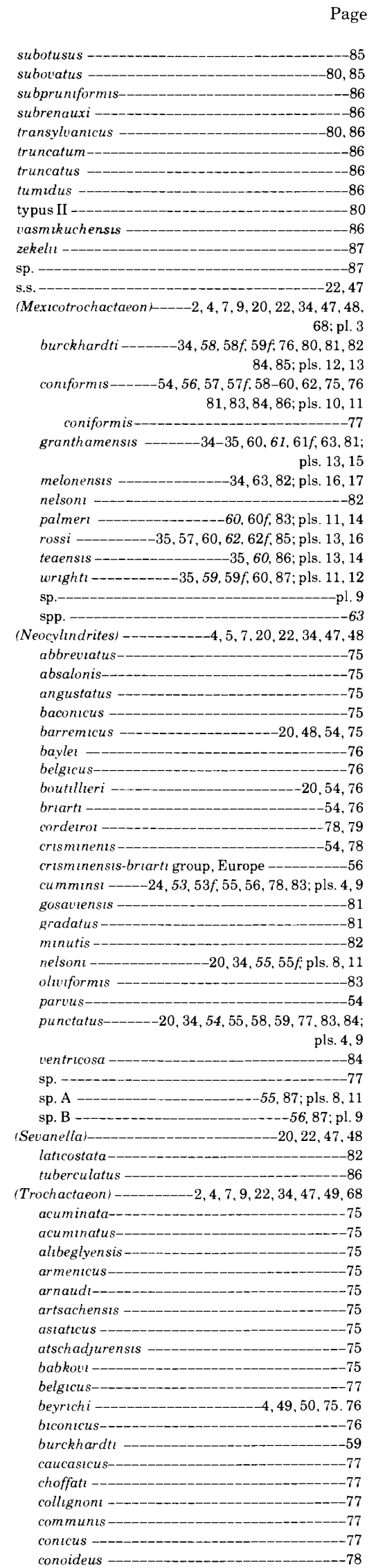

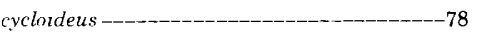

cylindraceus ---_-_-_-_-_---_-_--_-_-- 52,78

cylindricus --_-_-_-_-_-_-_-_-_-_-_-- 52,78

darwasensis --_-_-_-_-_-_-_-_-_-_-_-_--_--79

dubertrett -_-_-__-_-_-_-_-_-_-_-____- 79

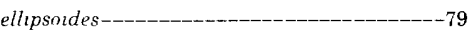

ellipticus -_-_____-_-_-_-_-_-_-_-_-_-_-_- 79

excelsus-----------------------------79

frazterensts --_-----20,22, 24, 50,51, 79,85; pl. 8 galloproc'tncialıs--.-----_-_-_-- $59,79,80$ ghaztrensis --_-_-_-_-_-_-_-_-_-_-_--- 80

giganteus -_-_-_-_-_-_-_-_-_..-_-_-_-- 80,84 giganteus -------_-_-_-_-_-_-------80 subglobosa --_-_------_---_-_-_-_-_---80

subglobosus -____-_ $78,79,80,82,86,87$ glandiformis-_-_-_-_-_-__-_-__-_-_-_-_-_ 80 goldfusst --_--_-_-_-_-_-_----77, 80, 81, 82, 86 gulsstanensts ----------_-_-_-_-_-_-_---81

humet --_--_-_-_-_-_-_-_-_-_-_-_-_-_-_-_-_---81 Idjevanensis -_-_-_-_-_-_-_-_-_-_-_-_-_-_-_-_81

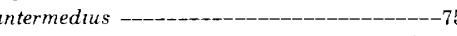
kuehni--_-_-_-_-_-_-_-_-_-_-_-_-_ 80,8

(Trochactaeon) abbreviata, Actaeonella--_-_-_-_-_--75 acuminata, Trochactaeon--_-_---_-_-_-_--- 75 acuminatus, Trochactaeon---_-_-_-_-- 75 acuttsstma punctata, Actaeonella---54, 56, 58, 77, 84

Actaeonella -_-_-_-_ altbeglyensis. Trochactaeon--_-_-_-_-_-_--- 75

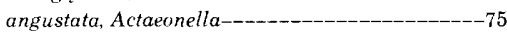
armentcus, Trochactaeon---------------------75 arnaud, Trochactaeon---------------_--------75 artsachensts, Trochactaeon--_-_-_-_-_-_-_-- 75 astaticus, Trochactaeon --_-------_-_-_-_------75 atschadjurensis, Trochactaeon --_-_-_-_-_-_--75 babkoul, Trochactaeon--_-_-_-_-_-_--_-_-_-_--75 bayler, Actaeonella-_-_-__-_-_-_-_-_-_-_ belgicus, Trochactaeon---_--_-_-_-_--------77 bevrtcht, Trochactaeon -_-_-_-_-_4, 49, 50, 75, 76 biconicus, Trochactaeon--_-_-_-_-_-_-_-_-- 76 brev's, Actaeonella-_-_ 48, 56, 76, 77 
Page

burckhardtu, Actaennella -___-_-_._-_-_47,58,76

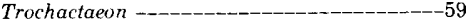

caucasicus, Trochactaeon--_-_--_-_--------77

choffatı, Trochactaeon --_-_-_-_-_-_-_-_-_-_-_- 77

collignoni, Actaeonella--_-_-_-_-_-_-_

Trochactaeon --_-_-_-_-_-_-_-_-_-_-- 77

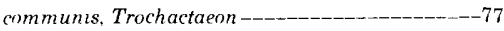

conica, Actaeonella-_-_-_-_-_-_-_-_-_-_-_6. 77

conicus, Trochactaeon -..------

coniformts, Actaeonella -------_-_--_48, 56,77,84

conoidea, Actaeunella--_-_----_---18

conoıdeus, Trochactaeon --_-_-_--_-_-_-_-_--78

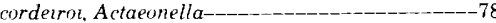

cossmanni, Trochactaeon-_-_-_-_-_-_-_-_---- 78

cyclosdeus, Trochactaeon --_-_-_-_-_-_-_-_---78

cylindracea, Actaeonella --___-_-_-_-----52, 78

cylendraceus, Trochactaeon -_-_-_-_-_--- 52.78

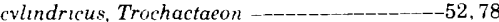

daruasensts. Trochactaeon --_-_-_-_-_-_-_-_9

dubertreti. Trochactaeon -.-_-_-_-_-_-_-_

ellipsoudes, Trochactaenn-_-_-_-_-_._-_-_-_-79

ellipticus, Trochactaeon -_-_-_-_-_-_-_-_-_-_-_ 79

excelsus, Trochactaeon---_-__-_-_-_-_-_-_-- 79

frazterensts, Trochactaeun-_--20,22, 50, 51, 79, 85 .

pl. 8

gallnprovinctalts, Trochactaern-_-_-_59, 79,80 ghaztrensts. Trochactaeon --_-_-_-__-_-_-_-_ gegantea. Actaconella -_-_-____-_ 48, 58, 79, 80 gigantea. Actaemella--_-_-_-_-_-_-_-_-_-_ 80 glubosa, Actaennella--_-_-_-_-_-_-_-_ glibosa, Actaennella-
subglobosa, Actaeonella--_--_ventricosa. Actaeonella-_-__-_-_-_-_-_-_-_- 80

giganteus giganteus. Trochactaeon -_-__-_-_- 80 subglobosa. Truchactaeon --_-__-_-_-_-----80 subglnbosus, Trochactaeon -78,79,80,82, 86, 87

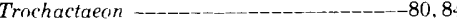

glandiformes, Trochactaeon--....-_-_-_._-_-_-

goldfussi, Actaconella ---_--_-_-_-_-___-_-_80,81

Trochactaeon-_-_-_-_ 80, 81, 82, 86 gulistanensis. Trochactaeon -__-_-_-_-_ Humboldtr, Actaeonella -_-_ 58, 76, 81 humer, Actaeonella---_--_-_-_-_-_-_..---81

Trochactaern -..-_-_-

idjevanensts, Trochactaeon -___-____-_-_-_-_

inconstans, Actaeonella

intermedius. Trochactaeon --_--_-__-_-- 75 irregularts, Actaeonella ----_-_-_---48, 56, 77,81 kuehni. Trochactaeon -_______________-_ 80,81 lamarckl, Actaeonella --_-_-_-_-_-___-_-_-_- 82

brandenbergensis. Trochactaeon-_-_._--- 82,83 lamarck?. Truchactaeon -_-_-_80, 82, 85, 86, 87 Trochactaeon --_-_-_-_-_-_-_-_-_-_. 9.51

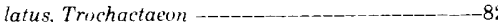
longlsulcus, Trochactaern---_-_-_-_-_-_- 85 mammilatus, Truchactaton----_-_-_--_------82 matensis, Actaernella-__.._-_-_-_-_-_-_-_-_ Trochactaem-_on-_-_-_-_-_-_22,51,52.79,82 murabults, Trichactaem --_---__-_----8 ubesus, Trochactaeon--_-_-_-_-_-_-_-_---82

-btusa, Truchactaeon -.-_-_-_-_-_-_-_-_---_83

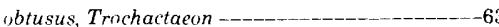
wceldentalts, Actaennella -_-_-_-__-_48, 56, 77, 83 urnatus. Trochactaeon -_-_-_-_-_-_-_-_-_-_-_ ouremensis, Trochactaenn-_-_-_____-_-__-_-_83
Page

wvalis, Trochactaeon-

$-83$

packardl, Trochactaeon _-_-_-_20,22, 51,52,52f, 68 ,

$83 ; \mathrm{pl} .8$

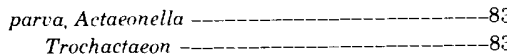

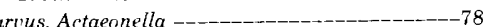

pcelinsevi, Trochactaeon-_-_-_-______-_49,50,84

planilateralss, Actaennella -----48, 54, 56, 77, 78.84

potosiana, Actaeonella -_-_-_-_-_-_48,56,77,84

prisca, Actaeonella --_-_-_-_-_-_-_-_-_-- 84

projectiliformis. Trochactaeon-_-_-_--_-_-_---84

pruniform is. Actaeonella --_-_-_-_-_ 58,84

pseudncylindraceus, Trochactaeon -------22, 52, 84

quadriplicata. Actaconella--_-_-_-_-_58, 76, 84

quadriplicatus. Actaeonella---_-_-_-_-_-_-----47

regularts, Trochactaeon--_--_-_-_-_-_-_-_-_-_4

renauxiana. Actaeonella--_-_..--_-_-_-----84, 85

renauxianus, Trochactaeon ---_-_-_-_-_-_-_--84

salomonis, Actaeonella-_______-_-_ 82.85

Trochactaeon --_-_-_-_-_-_-_-_-_-_-_-_-85

sanctaecructs, Trochactaeon--_-_-_-- $59,80,84,85$

scalatus. Trochactaeun-_-_-_---_-_-_-_-_-----85

schirabadensis, Trochactaeon --_-_-_-_--- 75,85

solidus, Trochactaeon --

specwsus, Trochactaeon--_-_-_-_-_--

subangustatus, Actaeonella-____.._-...._-___._-_-_78

subpruniformes, Trochactacon-_-_-_-_-_-__-_-86

subrenauxi, Trochactaeon --------------------86

szontaghi. Trochactaeon --_-_-_-_-_-_-_-_---86

Tovusensis, Trochactaeon -_-_-_-_-_-_-_-_-_-79, 86

Trochactaeon-_-___ 22, 47,68

truncatus, Trochactaeon --_-_-__-__-_____-_86

tubercles, in Late Cretaceous Trochactaeon

species -1

tumidus, Trochactaeon -----_variabilts, Actaeonella -_-_-__-_ 48, 56, 77, 86 'arıspiralıs, Trochactaeon--_-_-_-_.--_-_-_---86 rasmikuchensts. Trochactaeon -_-_-_-_-_-_---86 'ediensis, Trochactaeon-_-_-_-_-_-_-_-----86 uoodst, Actaeonella --_-_-_-_-_-_-_-_-_-_49,87

Trochactaeon 4, 20, 22, 34, 47, 49, 49f, 87; pls. 4-7 zekelu, Trochactacon --_-_-_-_-_-__. Actaeonella, sp.-_-__-_-_-_-___-_-_ 58.87 tropical brotic realm--_--_-_-_---_-_-_truncata. Actaeonella-_-_-_-_-_-_-_-_-_-_-_-_-_--86 truncatum, Trochactaenn-_-_-_--_-_-_-_-_-_-_-_-86 truncatus, Trochactaeon --_-_-_-_-_-__-_-_-_---86

Trochactaeun (Trochactaeon)-_...._-_-_-_-_-_--86 tuberculata, Sevanella - - ---tuberculatus, Truchactaeon (Sevanella)---_-_-_-_---86 tumida. Actaeonella-------_-_-----_-_------86 tumidus. Trochactaeon -_-_-_-_-__-_-_-_-_-_-_--86 Truchactaeon (Trochactaeon)-_-____________-_86 Turonıan tıme interval-_-_-_._-_-_-_-_-----9.10f Turritella --_--_-_-_-_-_-_-_-_-_-_-_

cummunts---_-_-

U

uchauxensis, Actaeonella--__-_._-_-_----64, 76, 81, 86 Actennella--_-_- 64.86

Upper Cretaceous rocks, correlations -_-_-_-_---26f, $27 f$
Page

variabilıs, Actaeonella (Trochactaeon)-----48,56,77,86 Mexicotrochactaeon - --_-------_-_-_---_56,77

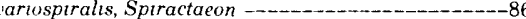
Trochactaeon (Trochactaeon)_________________-86 t'asmikuchensts, Mesotrochactaeon--_-_-_-_-_-_--_86

Trochactaeon --_-_(Trochactaeon) --_-_-_-_-_-_-_-_-_-_-_-_-_-_86

Vaughansfield Limestone, Jamaica -_-_-_-_-_-_--_--44 vediensis, Purpuractaenn-_-_-_-_-_-_-_-_-_-_-_--_86

Trochactaeon (Trochactaeon)-_-_-_--_--_---_--86

ventricosa, Actaeonella (Trochactaeon) gigantea--_-_-80

Neotrochactaeon--_-_- 80,87

Trochactaeon (Neocylindrites) -_-_-_-_-_-_-_-_84

ventricosus, Neotrochactaeon-_-_-_-_-_-_-_-_-

Verned ta gastropods affinity with Indo-Pacific faunas-_-_-_____-_-_35

Vernedia repelint-_-_-_-_-_-__-__-__-_-_-_-_

Virgin Islands, locality --_---_-_-_-_-_-_-_-_-_-_--40

Vuluta scalata--------------2-10

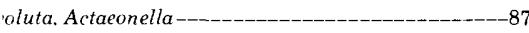

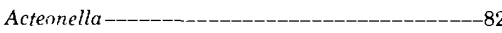

Volvarıa crassa----_-_-_-_-_--_-_-_-_-_--_--_- 78

faba-n.......--

laevis-_--_-_-_-_-_--_-_-_-_-_--_-_-_--63-64.81

(Volvarla) sublaevis, Actaeonella-...--_-_----66.85

Volvulina crassa--_-_-_-_-_-_-_-_-_-_-_------78

laev's-_-_-_-_-_-_-_-_-_-_-_-_-_-_-_-_-_-_81

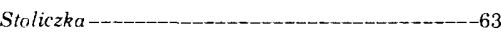

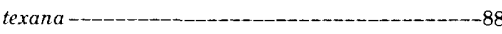

(Volvulina) inflata, Actaeonella--_-_-_-_-_-_------81

laevis, Actaennella --_-_-_-_-_-_-_-_-_-_-_--77,81

schtosensts, Actaeonella--------_---_------77, 85

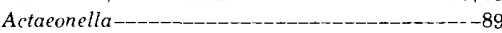

Vorderstoder, Austria --_-_-_-_-_-_-_-_-_-_-_-_-_--- 7

Washita Group, Texas, localities----_-_...--

West Africa---_-_-_.........-_-_-_-_-_-_-_-_-_---20

Western Hemisphere stratıgraphic ranges --_-.--22, $28 f$

Woodland Shale, Jamaica -

Woodman Creek. Shasta County. California --------46

Woods Hole, Mass.

woodst. Actaeonella iTrochactaeon--__

Trechactaeon (Trochactaeon)-_-_-_-4, 20, 22,34, 47, 49. $49 f, 87$; pls $4-7$

uright, Trochactaeon (Mexicotrochactaeon) $-59,59 f, 60$

87 ; pls. 11,12

Yukon Ruver, Alaska --_-_--_-_-_-_-_-_-_- 46

zekelu, Actaeonella Sogdianellat _-__________._90

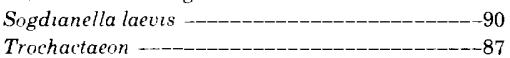

(Trochactaeon) --_-_-_-_-_-_-_-_-_-_

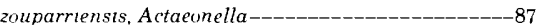

Actaeonella caucastca--_-_-_-_-_-_-_-_-_-_-_77,87

(Pchelincevella)-_-_-

zumoffent, Actaeonella-_-_-_---_-_-_-_-_-_---90

Eotrochactaeon-_-_-_-__-___-___-_ 90 
PLATES 1-23

Contact photographs of the plates in this report are available, at cost, from U.S.

Geological Survey Library, Federal Center, Denver, CO 80225. 


\section{PLATE 1}

Polished section $(\times 1)$ of oriented rock surface from roadcut immediately northwest of Morgan Mill, Erath County, Tex. USNM 305995 . Arrow " $A$ " points to some of the specimens of Actaeonella sp. in presumed life position, as discussed in text section on life mode. Note also overlying interval (arrow " $B$ ") containing transported specimens of Actaeonella primarily oriented with axes parallel to bedding but with the apertures unoriented. Note also the geopetal filling of the fossils. 


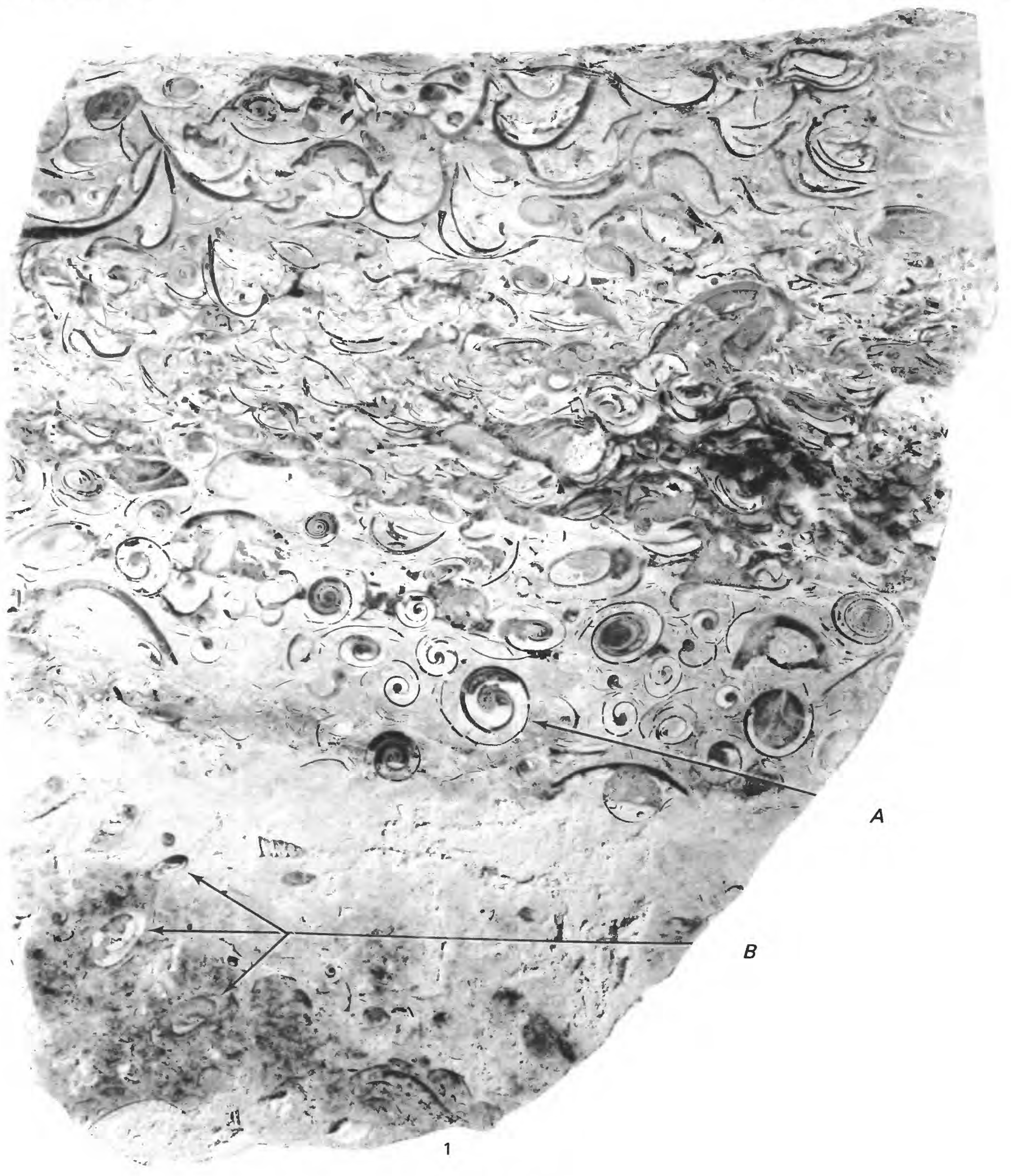




\section{PLATE 2}

Figures 1, 2. Trochactaeon (Mexicotrochactaeon) sp. (p. 9).

1. Aperture view $(\times 50)$ of a specimen, showing heterostrophic protoconch and early development of shell. Guinea Corn Formation, Central inlier, Jamaica, at locality 61. USGS 29972, USNM 305996.

2. Aperture view $(\times 50)$ of a specimen, showing both heterostrophic protoconch and the proportionally rapid increase in whorl diameter compared with height of early growth stages. Guinea Corn Formation, Central inlier, Jamaica, at locality 61. USGS 29972; USNM 305997.

3. Actaeonella sp. (p. 9)

Aperture view $(\times 30)$ of a specimen, showing heterostrophic protoconch and initial stage of envelopment. "Titanosarcolites limestone," Marchmont inlier, Jamaica, at locality 97. USGS 30026; USNM 305998.

4. Actaeonella sp. (p. 9)

Aperture view of a juvenile specimen $(\times 45)$, showing heterostrophic protoconch and early developmental stage. "Titanosarcolites limestone," Marchmont inlier, Jamaica, at locality 97. USGS 30026; USNM 305999.

5. Actaeonella sp. C. (p. 74).

Apertural view $(\times 1)$ of a specimen from along the Yukon River, Alaska, at locality 170. USGS 2179; USNM 306203.

6. Actaeonella cf. A. coquiensis Sohl and Kollmann (p. 71).

Polished section $(\times 1)$ of a specimen of Melones Limestone from the Puerto Real Quadrangle, Puerto Rico, at locality 31, that shows a concentration of Actaeonella. USGS 27014; USNM 305600. 

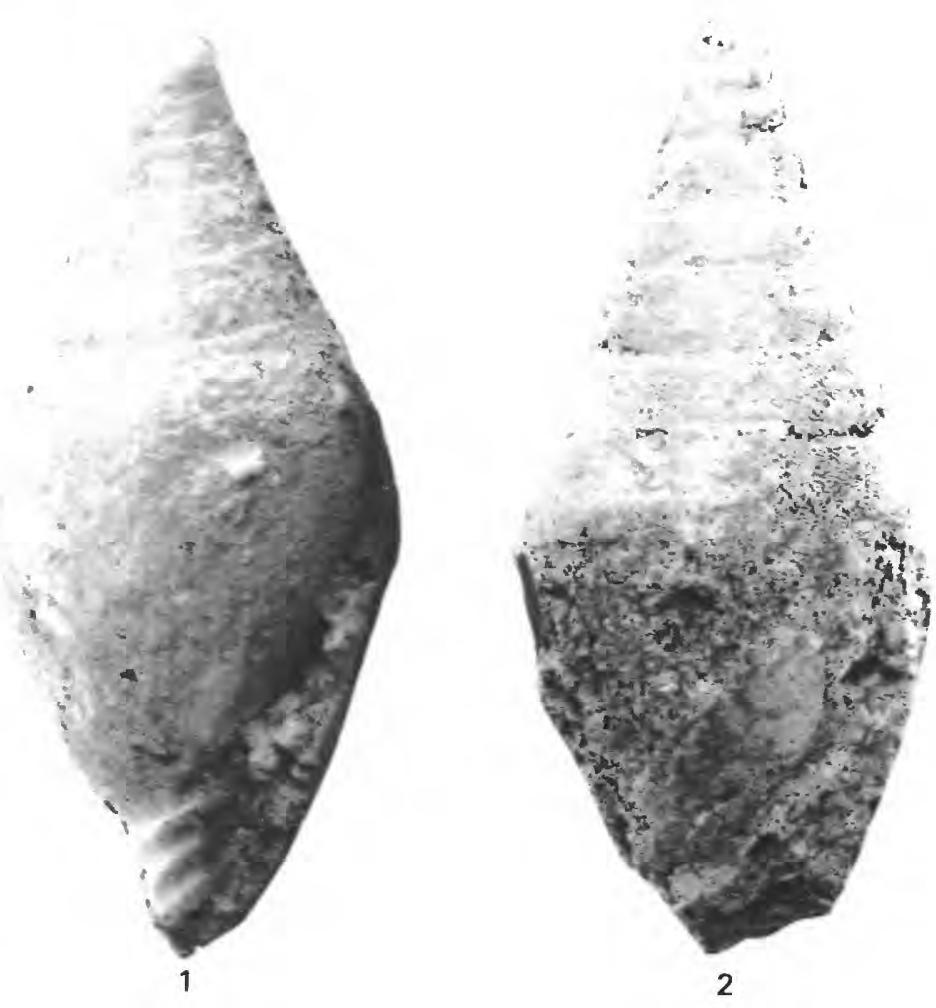

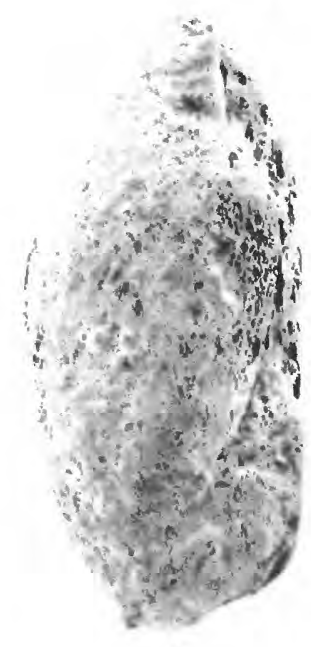

3
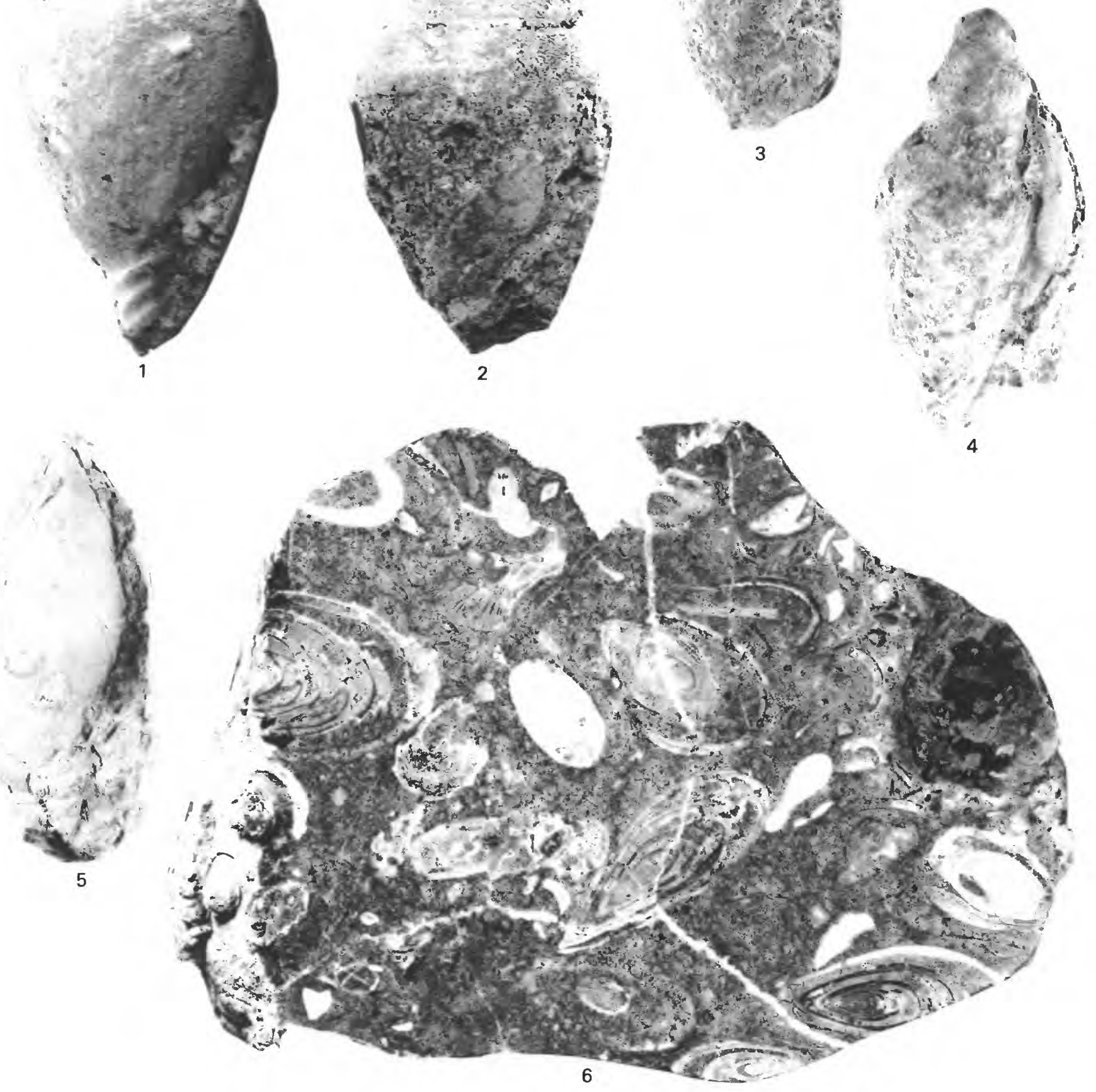

TROCHACTAEON (MEXICOTROCHACTAEON) AND ACTAEONELLA 
PLATE 3

FiguRES 1-4. Views of the heterostrophic protoconch $(\times 350)$ of a specimen of Trochactaeon (Mexicotrochactaeon) (p. 9) from the Guinea Corn Formation, Central inlier, Jamaica, at locality 61. USGS 29972; USNM 306202. 

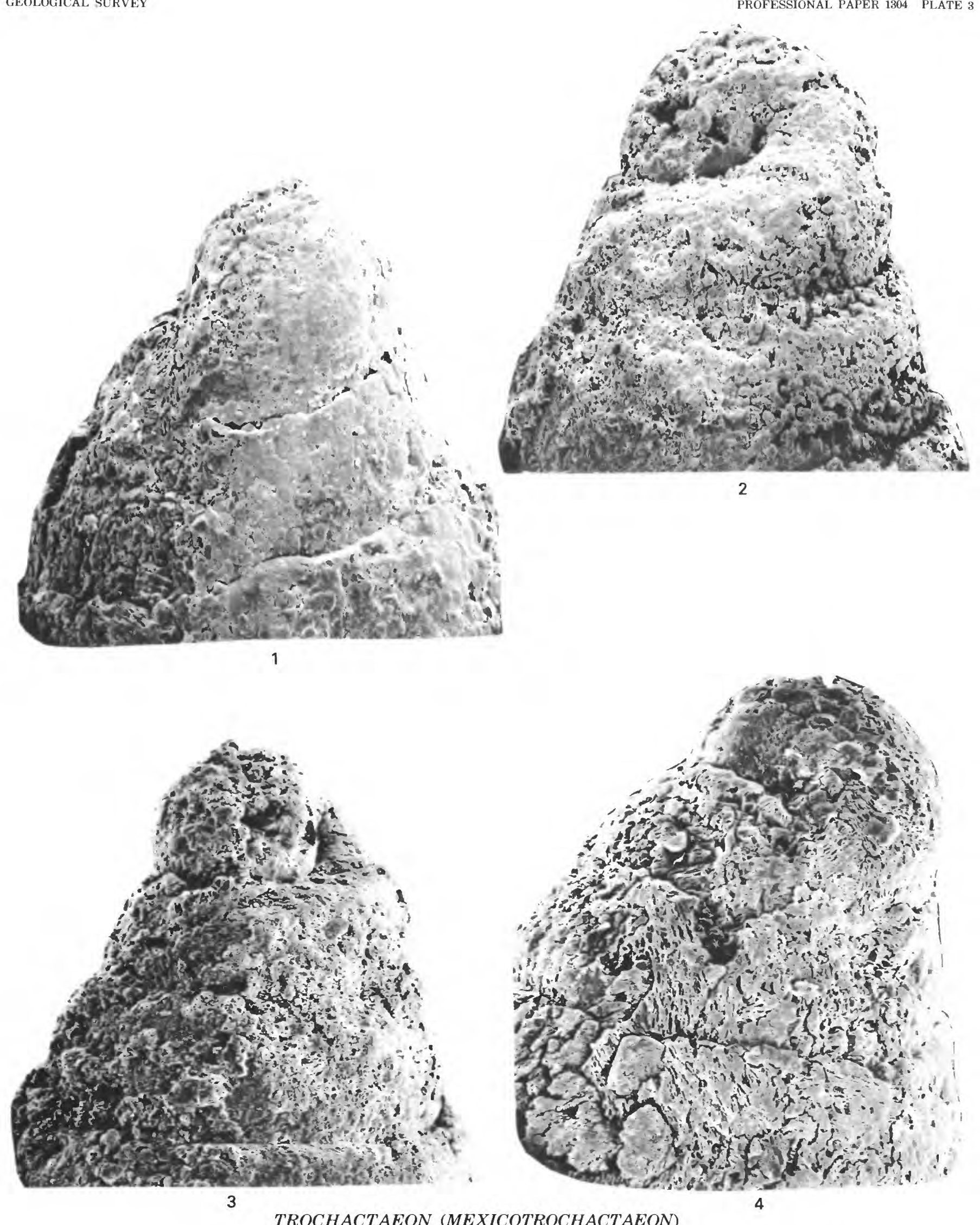

TROCHACTAEON (MEXICOTROCHACTAEON) 


\section{PLATE 4}

Figures 1-4. Trochactaeon (Neocylindrites) cumminsi Stanton (p. 53).

1. Camera lucida drawing ( $\times 1.5$ ) of an axial section though a specimen from the Washita Group, Texas, at locality 136. USGS 11853; USNM 306001.

2, 3, 4. Camera lucida drawings ( $\times 1$ ) of transverse sections through specimens from the Devils River Limestone, Texas, at locality 134. USGS 1941; USNM 306002-306004.

5. Trochactaeon (Neocylindrites) punctatus (Maldonado-Koerdell) (p. 54).

Camera lucida drawing $(\times 1)$ of an axial section through a specimen from the State of Chiapas, Mexico, at locality 151. USGS 11467; USNM 306005.

6-8, 12. Trochactaeon (Trochactaeon) woodsi (Rennie) (p. 49).

6-8. Camera lucida drawings $(\times 0.5)$ of axial sections through specimens from the Cotui Limestone, San German Quadrangle, Puerto Rico, at locality 39. USGS 30512; USNM 306006, 306016, 306017.

12. Camera lucida drawing $(\times 0.75)$ of axial section through a specimen from the Cotui Limestone, San German Quadrangle, Puerto Rico, at locality 39. USGS 30512; USNM 306007.

9-11. Trochactaeon (Trochactaeon) cf. T. (Trochactaeon) woodsi (Rennie) (p. 50).

Camera lucida drawings $(\times 0.5)$ of axial sections of specimens from the Pozas Formation, Orocovis Quadrangle, Puerto Rico, at localities 25 and 26. USGS 29099 and 30532; USNM 306008-306010. 

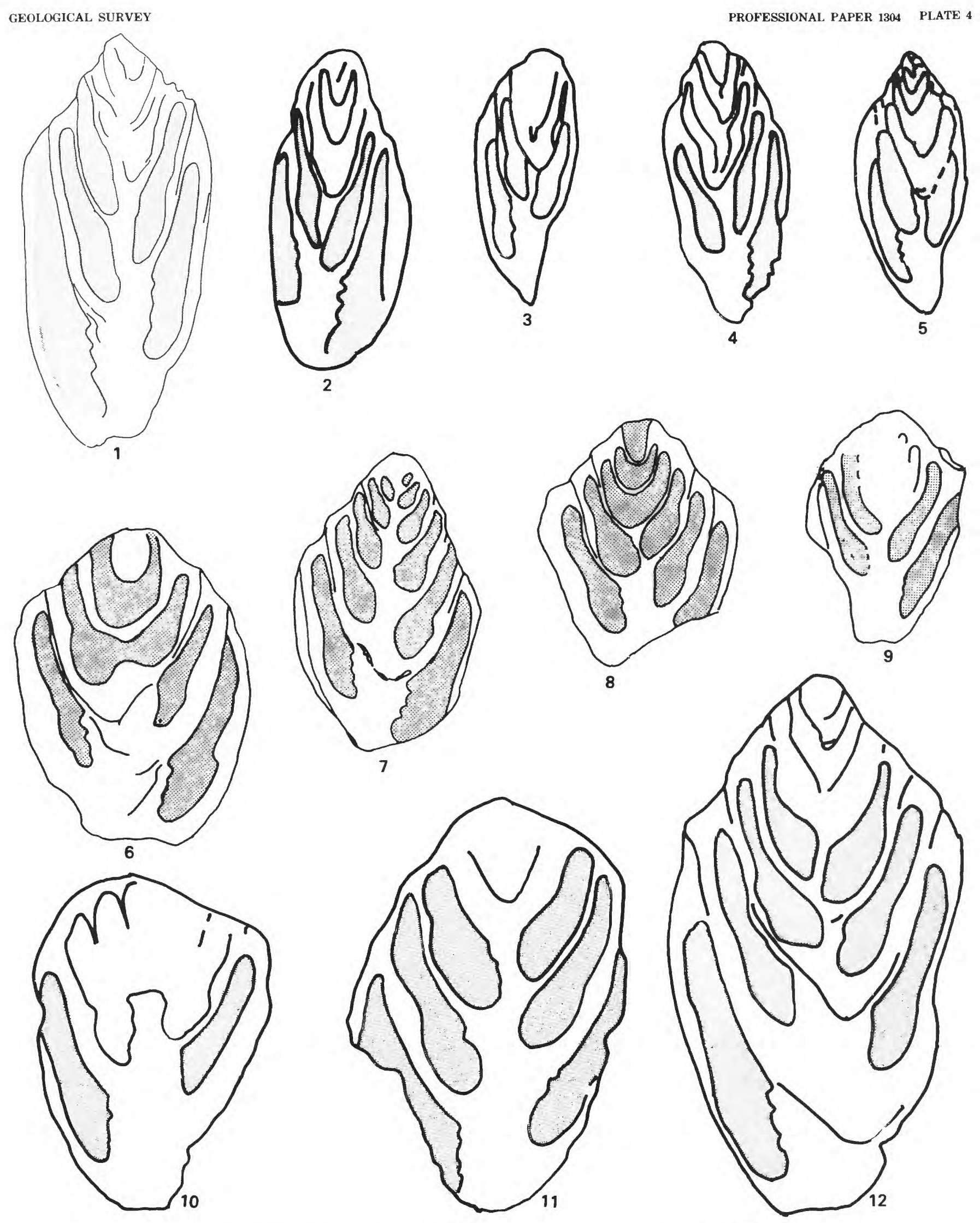

TROCHACTAEON (NEOCYLINDRITES) AND T. (TROCHACTAEON) 
PLATE 5

Figures 1-5. Trochactaeon (Trochactaeon) woodsi (Rennie) (p. 49).

1, 3. Back and aperture views ( $\times 1.5$ ) of a specimen from the Sabana Grande Formation, San German Quadrangle, Puerto Rico, at locality 43, which shows raised strong sinused growth-line lamellae at the shoulder nodes. USGS 30343; USNM 306011.

2. Aperture view $(\times 1)$ of a specimen from the Cotui Limestone, San German Quadrangle, Puerto Rico, at locality 39. USGS 30512; USNM 306012.

4. Aperture view $(\times 1)$ of a specimen from the same locality. USGS 30512; USNM 306013.

5. Polished axial-section view $(\times 1)$ of a specimen from the same locality. USGS 30512; USNM 306007 . 

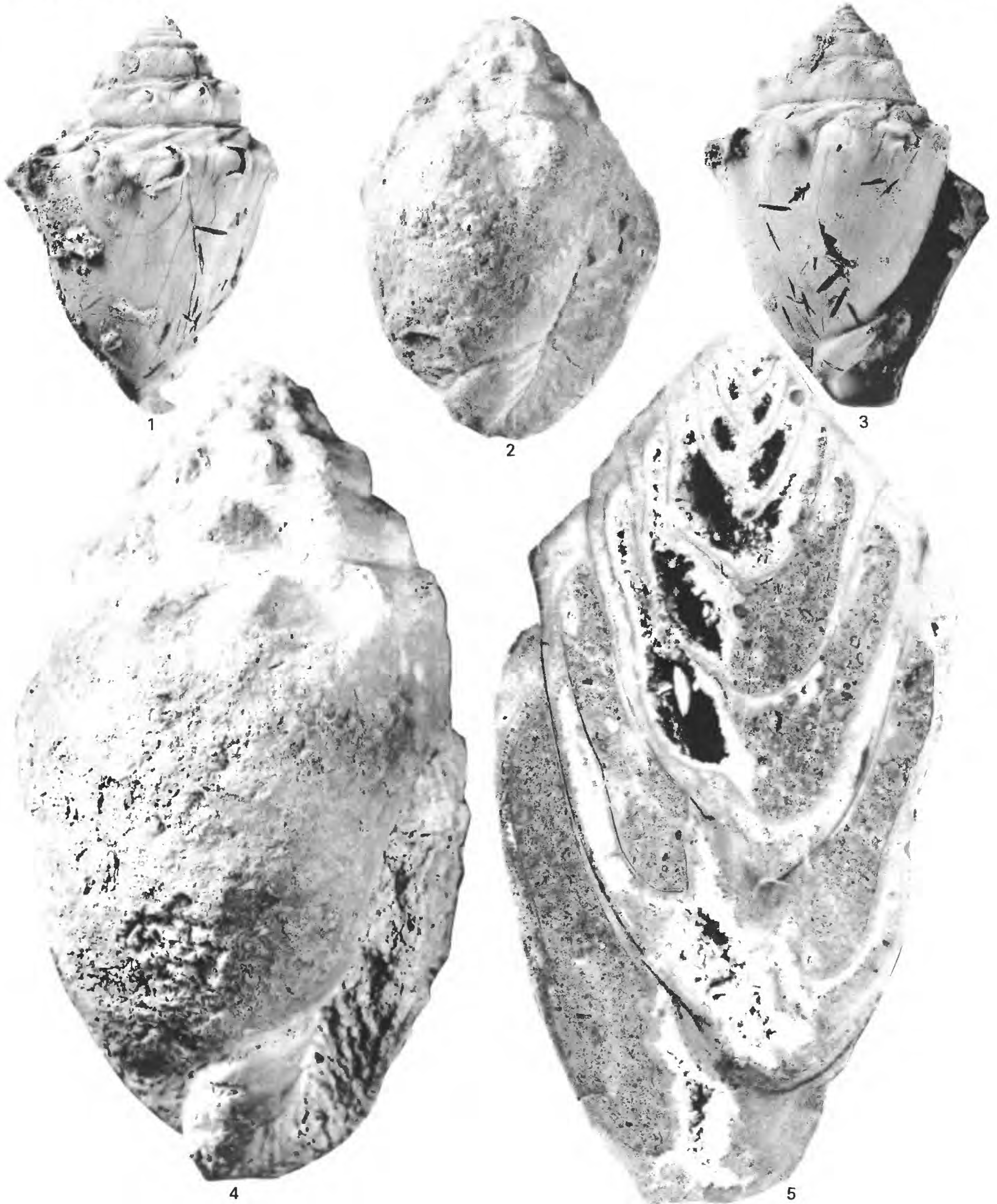

TROCHACTAEON (TROCHACTAEON) 


\section{PLATE 6}

Figures 1, 2, 4, 5. Trochactaeon (Trochactaeon) woodsi (Rennie) (p. 49).

1. Aperture view $(\times 1)$ of a specimen from the Pozas Formation, Barranquitas Quadrangle, Puerto Rico, at locality 5. USGS 29364; USNM 306014

2. Back view $(\times 1)$ of a specimen from the Cotui Limestone, San German Quadrangle, Puerto Rico, at locality 39. USGS 30512; USNM 306015.

4. View of polished axial section $(\times 1)$ from the same locality. USGS 30512; USNM 306016.

5. Back view $(\times 1)$ of a specimen from the same locality. USGS 30512; USNM 306018.

3. Trochactaeon (Trochactaeon) cf. T. (Trochactaeon) woodsi (Rennie) (p. 50).

Back view $(\times 1)$ of a small specimen from the Pozas Formation, Orocovis Quadrangle, Puerto Rico, at locality 26. USGS 30532; USNM 306019. 


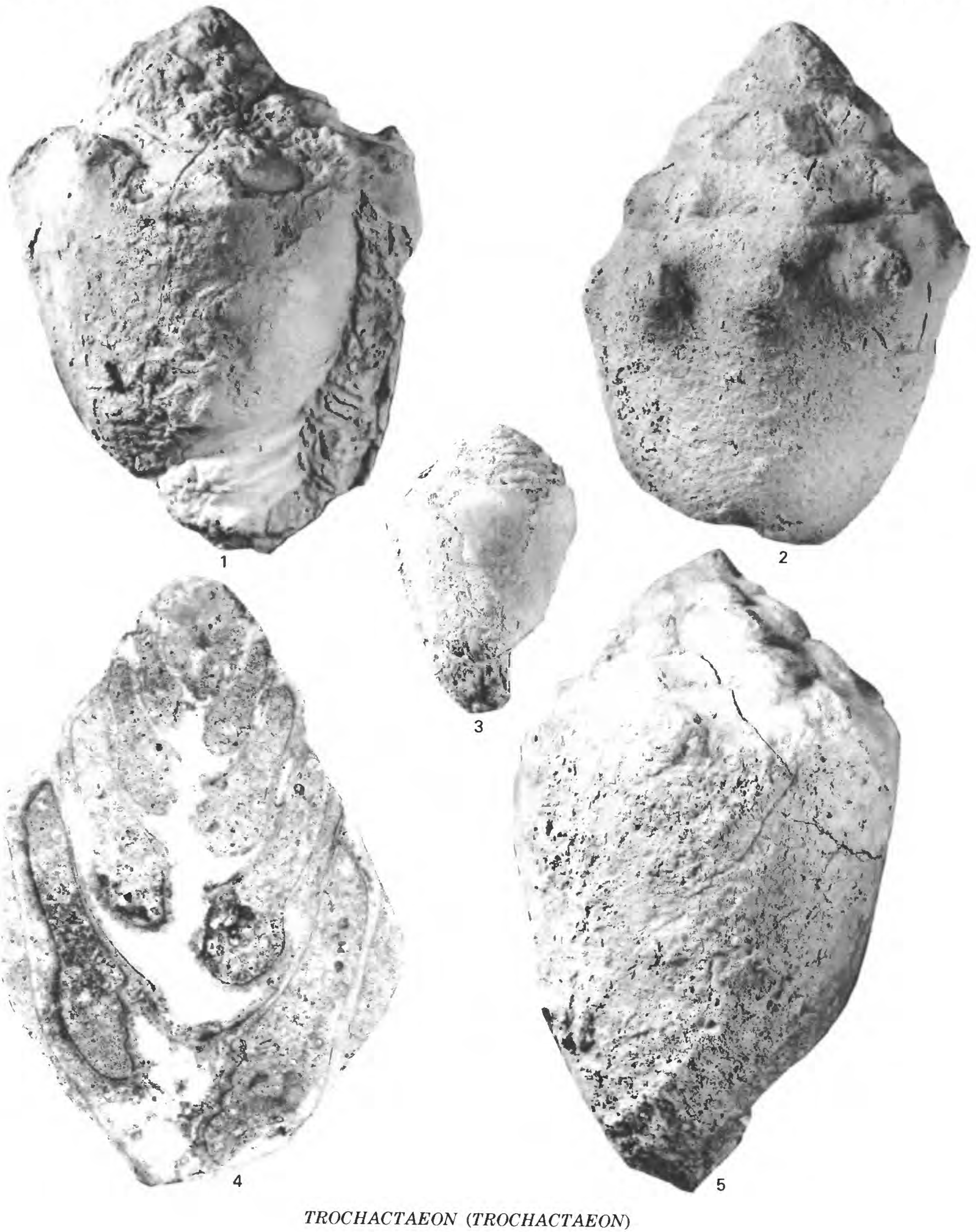




\section{PLATE 7}

Figures 1-3. Trochactaeon (Trochactaeon) cf. T. (Trochactaeon) woodsi (Rennie) (p. 50),

1, 3. Aperture and back views $(\times 1)$ of a specimen from the Pozas Formation, Orocovis Quadrangle, Puerto Rico, at locality 25. USGS 29099, USNM 306020.

2. Cut and polished axial section $(\times 1)$ of a specimen from the same locality. USGS 29099; USNM 306009.

4, 5. Trochactaeon (Trochactaeon) woodsi (Rennie) (p. 49).

4. Aperture view $(\times 1)$ of a specimen from the Cotui Limestone, San German Quadrangle, Puerto Rico, at locality 39 . USGS 30512; USNM 306021.

5. Aperture view $(\times 1)$ of a specimen from the Cotui Limestone, San German Quadrangle, Puerto Rico, at locality 29. Arrow points to attachment scar of a Requienia sp., a rudist bivalve. USGS 30512; USNM 306022. 

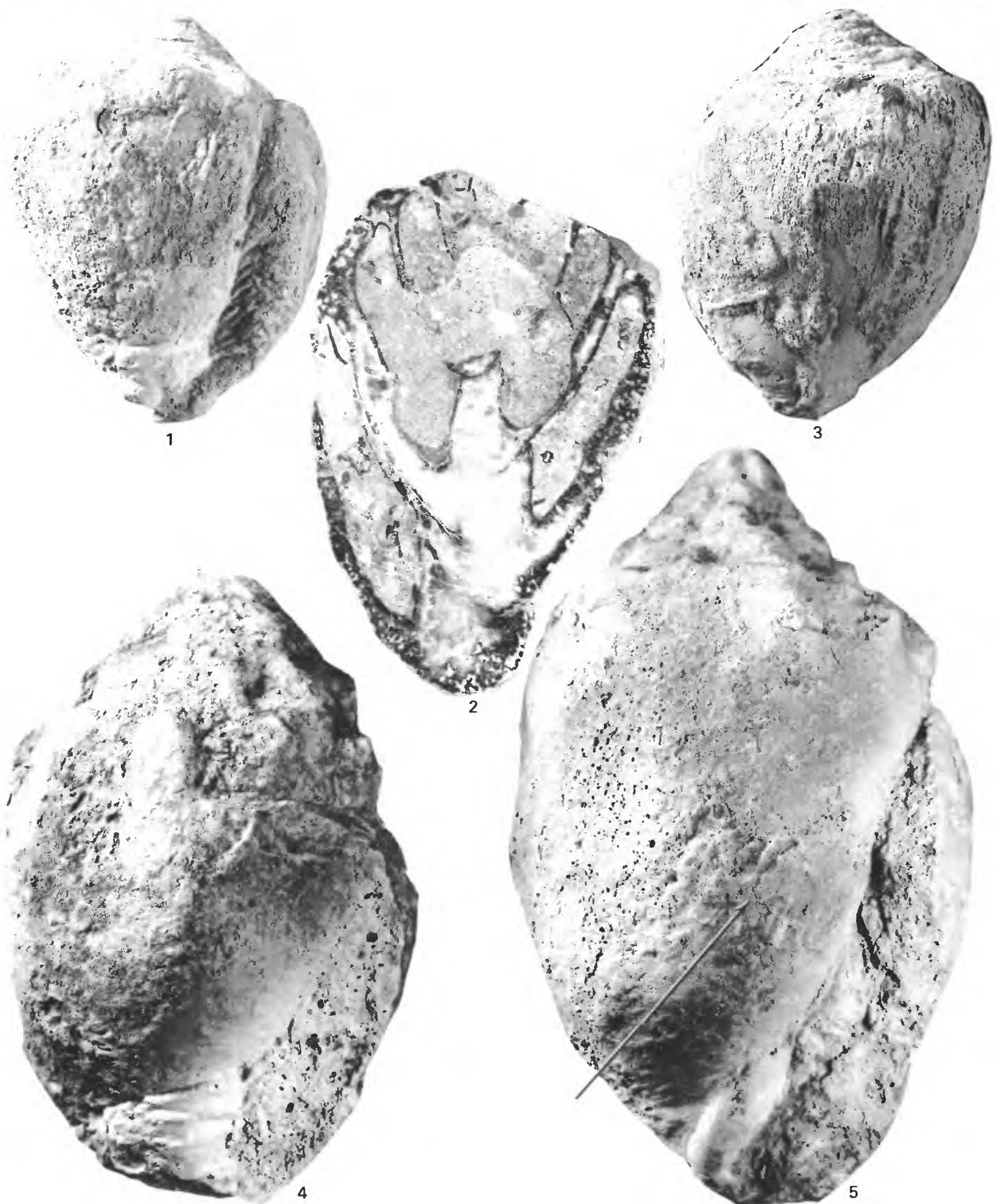


\section{PLATE 8}

Figures 1-5. Trochactaeon (Trochactaeon) frazierensis (Anderson) (p. 50).

1. Aperture view $(\times 1)$ of the holotype from the Turonian of Shasta County, Calif., at locality 162. CAS 10664.

2. Aperture view $(\times 1)$ of the holotype of Actaeonella rustica Anderson from the Turonian of Shasta County, Calif., at locality 162. CAS 10666.

3. Aperture view $(\times 1)$ of a specimen from the Turonian of Shasta County, Calif., at locality 165. CAS 53169.

4. Aperture view $(\times 1)$ of the paratype from the Turonian of Shasta County, Calif., at locality 162. CAS 10665.

5. Aperture view $(\times 1)$ of a specimen from the Turonian of Shasta County, Calif., at locality 165. CAS 53169. 6, 7, 8. Trochactaeon (Neocylindrites) sp. A. (p. 55).

6 , 8. Back and aperture views $\left(\times 2\right.$ and $\left.\times 1 \frac{1}{12}\right)$ of a specimen from the El Rayo Formation, Sabana Grande Quadrangle, Puerto Rico, at locality 36 . USGS 29075; USNM 306023.

7. Aperture view $(\times 1.5)$ of a specimen from the same locality. USGS 29075; USNM 306084.

9-14, 18, 19. Trochactaeon (Neocylindrites) nelsoni Sohl and Kollmann, n. sp. (p. 55).

9. Aperture view $(\times 4)$ of a paratype from the Pozas Formation, Orocovis Quadrangle, Puerto Rico, at locality 28. USGS 30534; USNM 306024.

10. Aperture view $(\times 4)$ of a paratype from the same locality. USGS 30534 ; USNM 306025 .

11. Aperture view $(\times 4)$ of a paratype from the same locality. USGS 30534 ; USNM 306026.

12. Aperture view $\left(\times 1 \frac{112}{2}\right)$ of a paratype from the Pozas Formation, Florida Quadrangle, Puerto Rico, at locality 23. USGS 28742; USNM 306027.

13. Aperture view $(\times 4)$ of the holotype from the Pozas Formation, Orocovis Quadrangle, Puerto Rico, at locality 28. USGS 30534; USNM 306028.

14. Aperture view $(\times 4)$ of a paratype from the Pozas Formation, Florida Quadrangle, Puerto Rico, at locality 24. USGS 29372; USNM 306029.

18,19 . Back and aperture view $(\times 1)$ of a paratype from the same locality. USGS 29372; USNM 306030.

15-17. Trochactaeon (Trochactaeon) packardi (Anderson) (p. 51).

15, 16. Aperture and back view ( $\times 1)$ of the holotype from the Turonian of Siskiyou County, Calif., at locality 163. CAS 10663.

17. Cut and polished axial section $(\times 1)$ of a specimen from the Turonian of Orange County, Calif., at locality 167. CAS 733. 

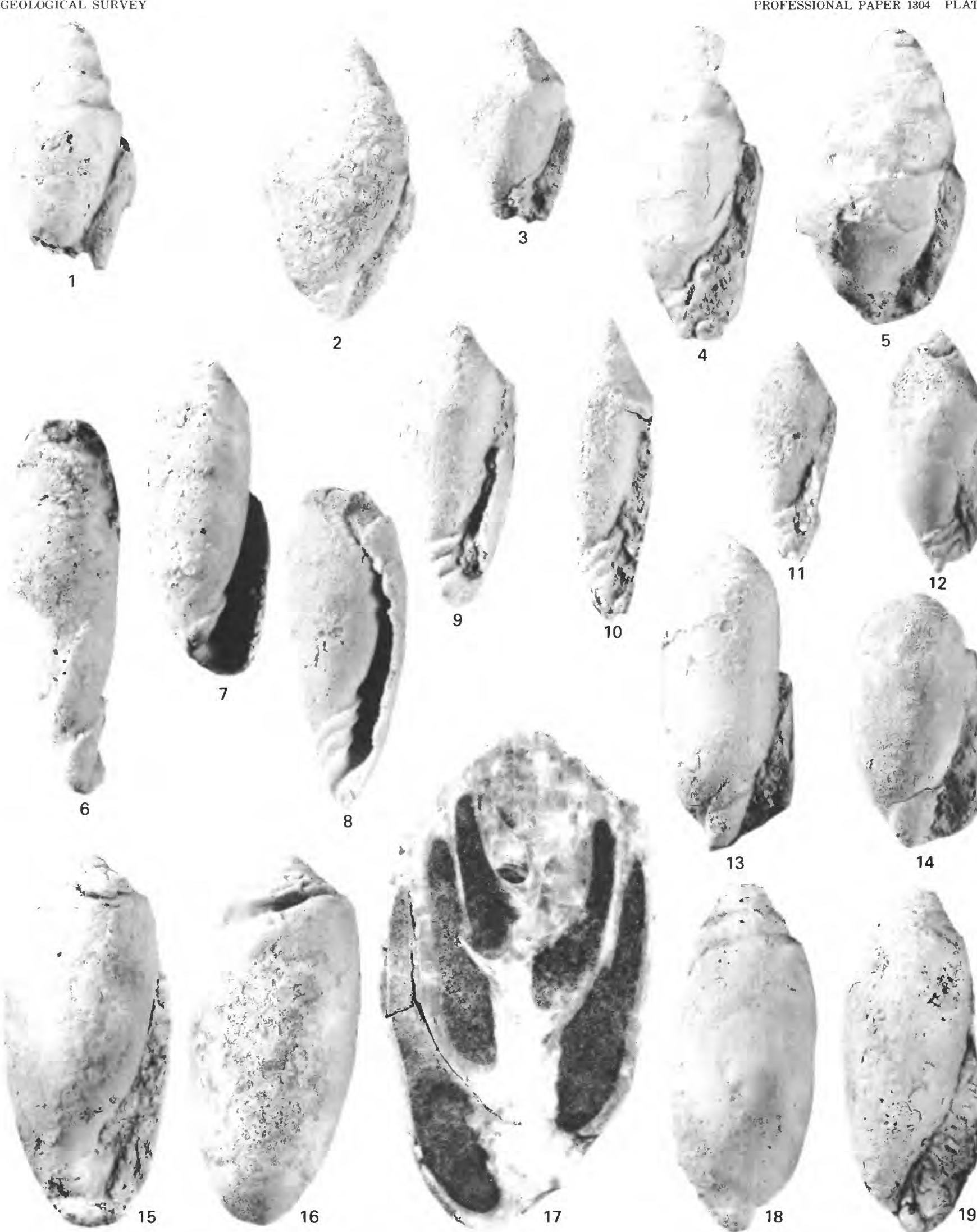


\section{PLATE 9}

Figures 1-6. Trochactaeon (Neocylindrites) punctatus (Maldonado-Koerdell) (p. 54).

1. Back view of a specimen $(\times 2)$ from limestones near Ocuilapa, State of Chiapas, Mexico, at locality 148. USGS 11467; USNM 306031.

2. Aperture view of a specimen $(\times 1)$ from the same locality. USGS 11467; USNM 306032.

3. Polished axial section of a specimen $(\times 1.5)$ from the same locality. USGS 11467; USNM 306033.

4. Aperture view of a specimen $(\times 1)$ from the same locality. USGS 11467; USNM 306034.

5 , 6. Aperture and back views $(\times 2)$ of a specimen from the same locality. USGS 11467; USNM 306035.

7, 8. Trochactaeon (Neocylindrites) sp. B. (p. 56).

7. Latex cast of an incomplete specimens ( $\times 1.5$ ) from the Mojado Formation, Hidalgo County, N. Mex., at locality 147. USGS 1694; USNM 306036.

8. Latex cast of a specimen ( $\times 1.5$ ) from the same locality. USGS 1694; USNM 306037.

9-19. Trochactaeon (Neocylindrites) cumminsi Stanton (p. 53).

9. Aperture view (× 1.5) of a syntype from the Devils River Limestone, Val Verde County, Tex., at locality 134. USGS 1941: USNM 306038.

10, 11. Back and aperture views of a specimen $(\times 2)$ from the same locality. USGS 1941; USNM 306039

12. Aperture view $(\times 1)$ of a syntype $(\times 1)$ from the same locality. USGS 1941; USNM 306040 .

13, 14. Aperture views $(\times 4)$ of the cotypes of Trochactaeon parvus Stanton from Edwards Limestone at the mouth of Bartons Creek near Austin, Tex. USNM 103123a, b.

15. Back view of a syntype ( $\times 1$ ) from the Devils River Limestone, Val Verde County, Tex., at locality 134. USGS 1941; USNM 306041.

16. Front view of the lectotype ( $\times 1$ ) from the same locality. USGS 1941; USNM 306042.

17. Polished axial section of a specimen $(\times 1.5)$ from the Washita Group near Big Lake, Reagan County, Tex., at locality 136. USGS 11853; USNM 306001.

18. Back view of a syntype $(\times 1.5)$ from the Devils River Limestone, Vale Verde County, Tex., at locality 134. USGS 1941; USNM 306043.

19. Aperture view of a syntype ( $\times 1$ ) from the same locality. USGS 1941; USNM 306044. 
GEOLOGICAL SURVEY

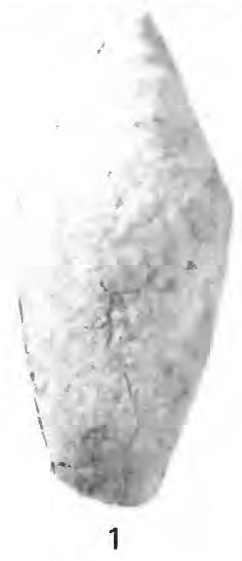

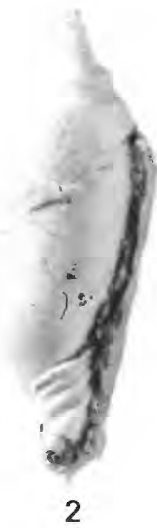
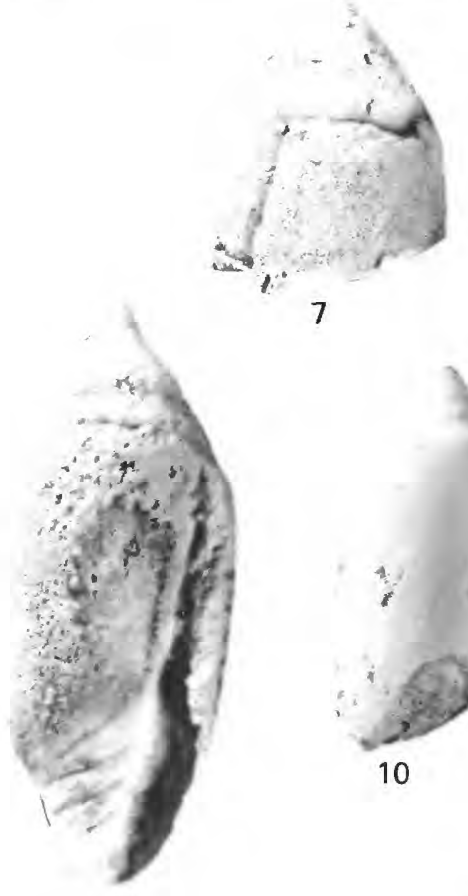

9

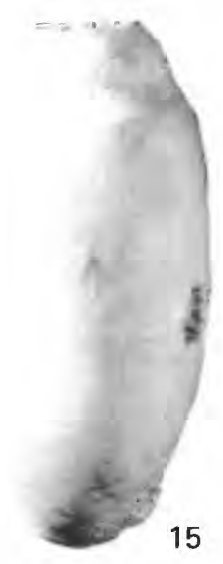

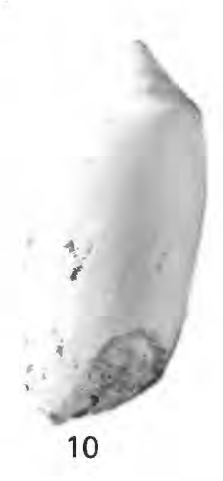

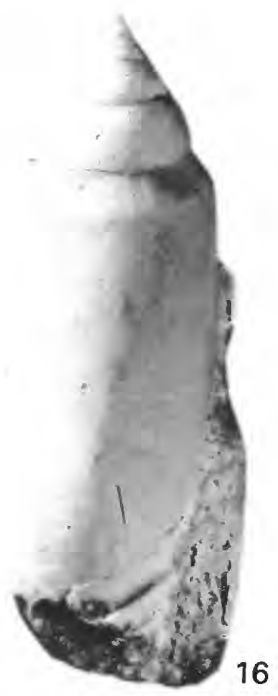

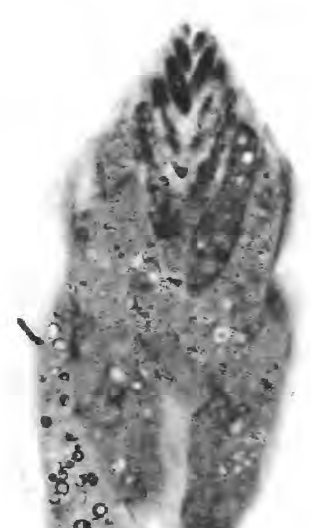

n.

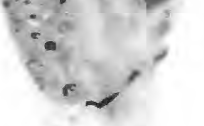

3
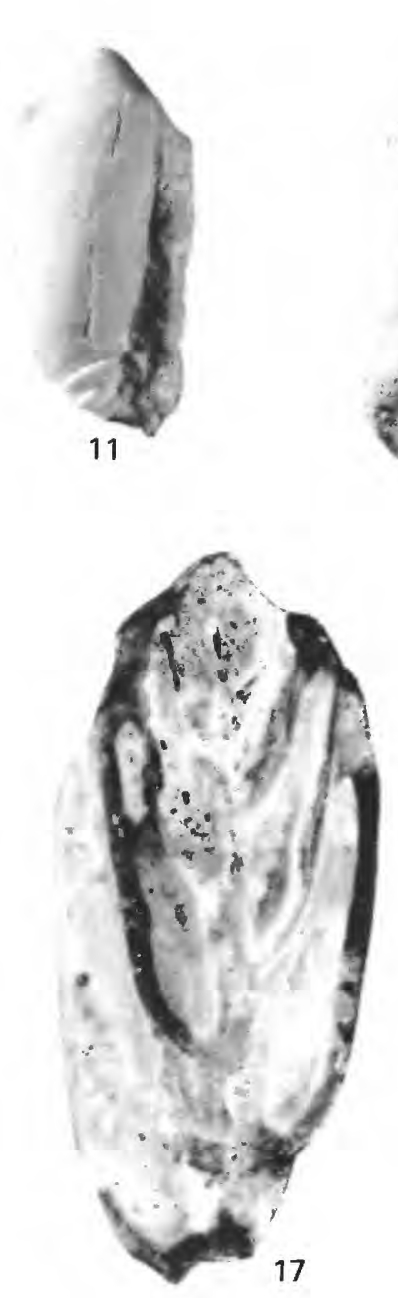

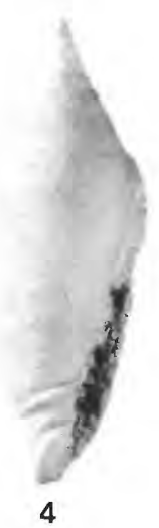

PROFESSIONAL PAPER 1304 PLATE 9
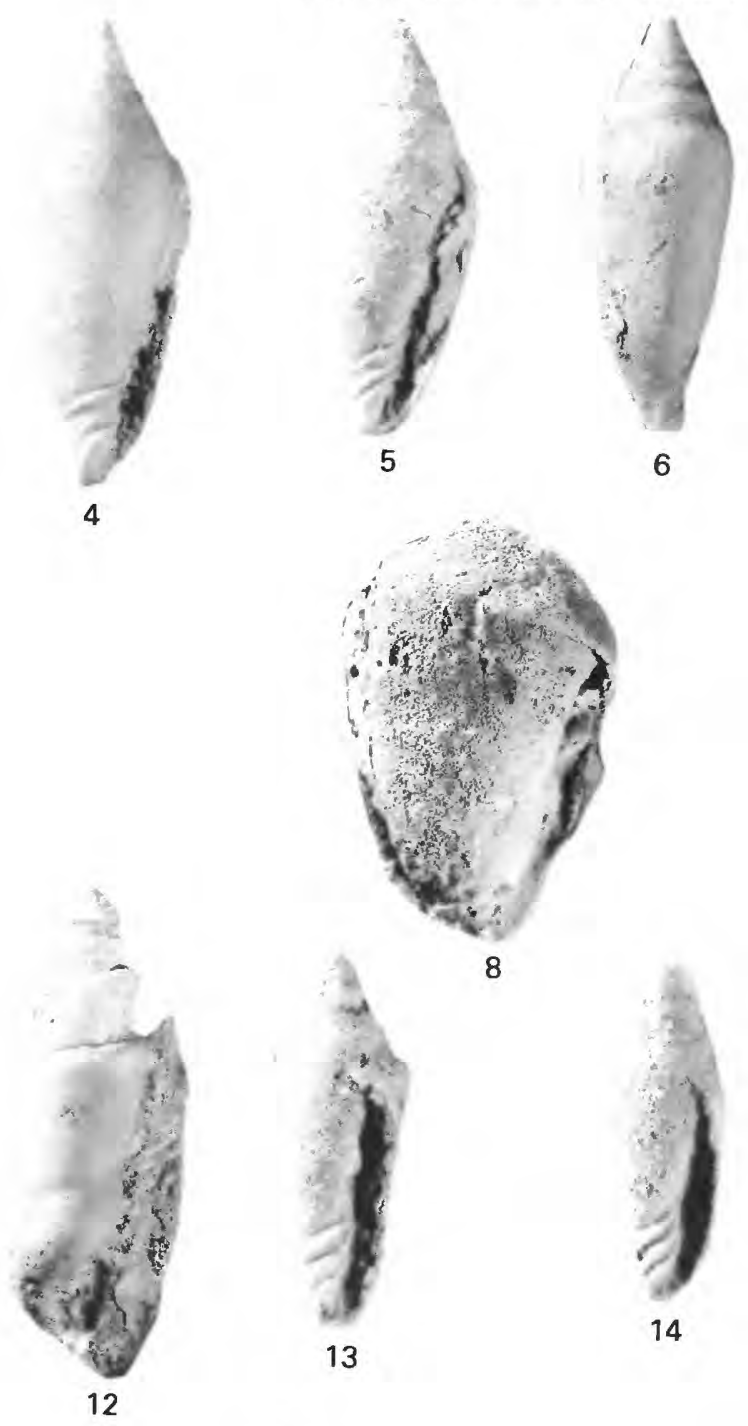

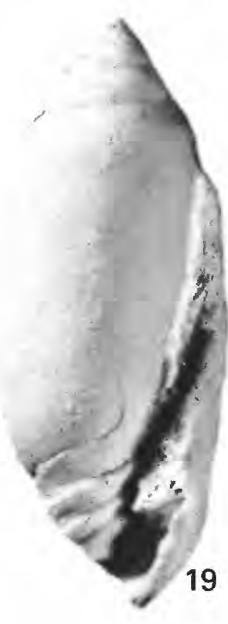

TROCHACTAEON (NEOCYLINDRITES) 


\section{PLATE 10}

Figures 1-17. Trochactaeon (Mexicotrochactaeon) coniformis (Böse) (p. 56).

1. Aperture view $(\times 3)$ of a specimen from the Cardenas Formation, State of San Luis Potosi, Mexico, at locality 157. USGS 28216; USNM 306045.

2. Aperture view $(\times 1.5)$ of a specimen from the same locality. USGS 28216 ; USNM 306046.

3. Aperture view $(\times 3)$ of a specimen from the same locality. USGS 28216; USNM 306047.

4, 5. Aperture and back views $(\times 2)$ of a specimen from the same locality. USGS 28216; USNM 306048.

6. Aperture view $(\times 1.5)$ of a specimen from the same locality. USGS 28216 ; USNM 306049 .

7. View $(\times 1.5)$ of an incomplete specimen from the same locality, showing form of columellar plaits. USGS 28216; USNM 306050.

8. Aperture view $(\times 1.5)$ of a specimen from the same locality. USGS 28216; USNM 306051.

9. View $(\times 1.5)$ of an incomplete specimen from the same locality, showing development of columellar plaits. USGS 28216; USNM 306052.

10. Aperture view $(\times 1.5)$ of a specimen from the same locality. USGS 28216; USNM 306053 .

11. Aperture view $(\times 1)$ of an especially large specimen figured by Myers (1968, pl. 7, fig. 3 ) from the Cardenas Formation, State of San Luis Potosi, Mexico. UT (WSA) 155 54a.

12. Aperture view $(\times 1.5)$ of a specimen from the Cardenas Formation, State of San Luis Potosi, Mexico, at locality 157. USGS 28216; USNM 306054.

13. Axial section $(\times 3)$ of a specimen from the same locality. USGS 28216 ; USNM 306055 .

14. Axial section $(\times 2)$ of a specimen from the same locality. USGS 28216; USNM 306056 .

15. Axial section $(\times 2)$ of a specimen from the same locality. USGS 28216; USNM 306057.

16. Axial section $(\times 3)$ of a specimen from the same locality. USGS 28216 ; USNM 306058 .

17. Aperture view $(\times 3)$ of a specimen from the same locality. USGS 28216 ; USNM 306059 . 
GEULOGICAL SURVEY

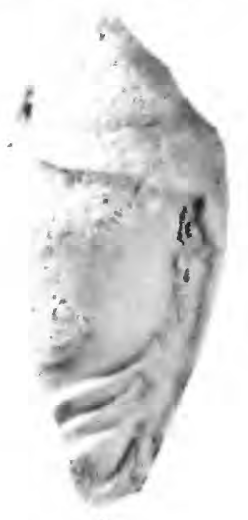

1
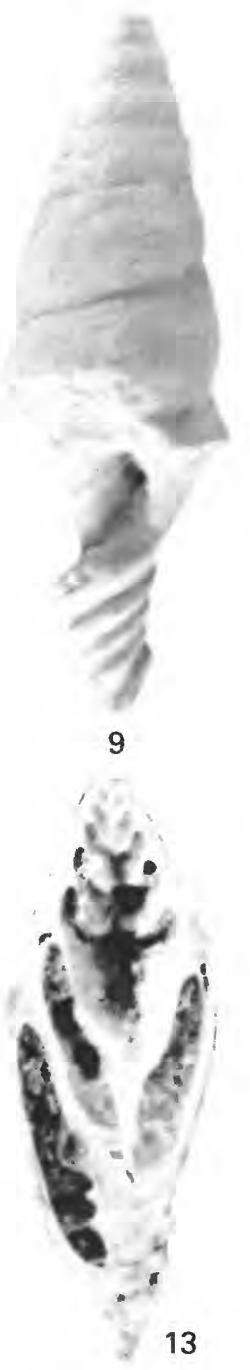
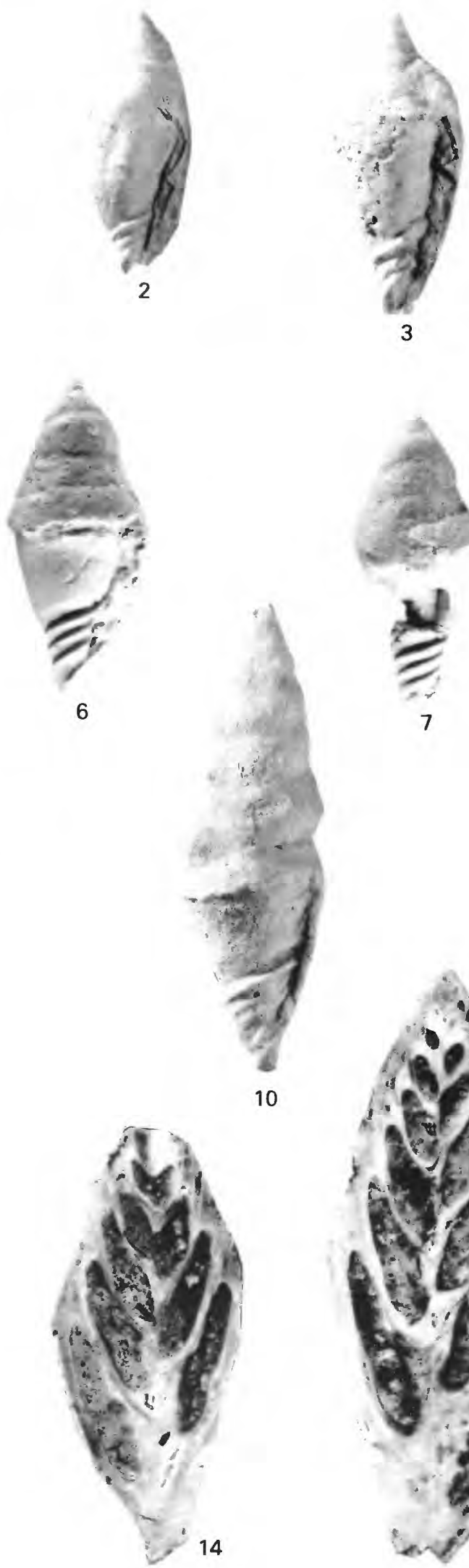

10
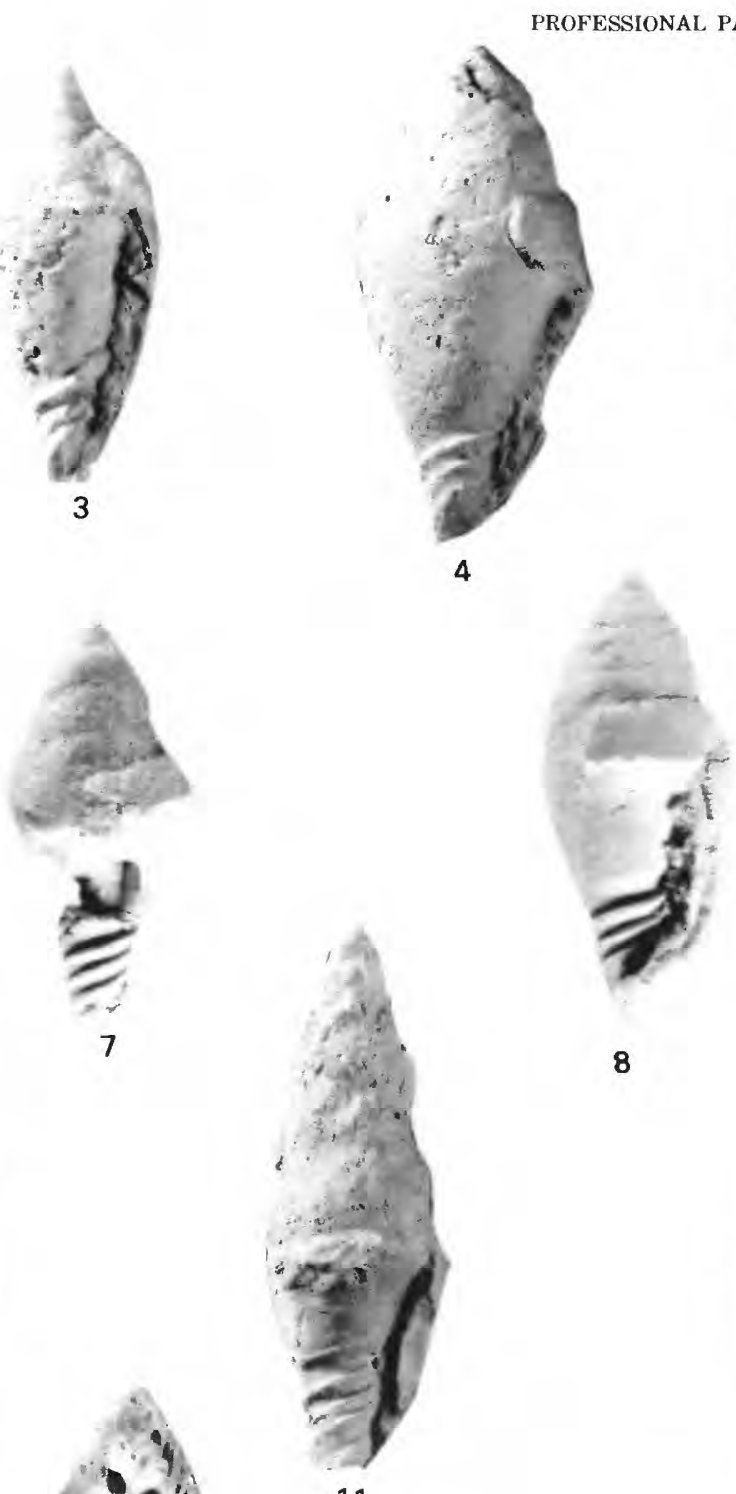

11
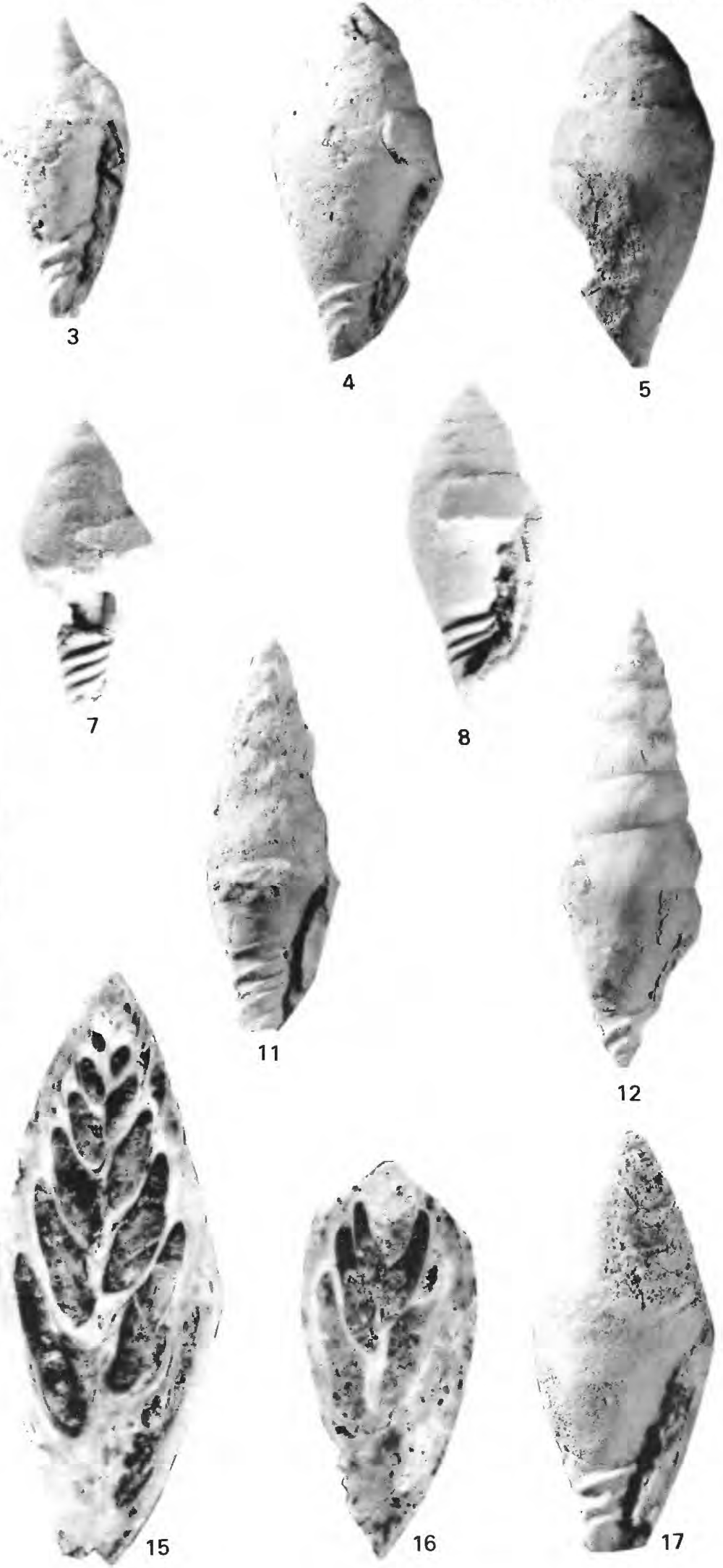

TROCHACTAEON (MEXICOTROCHACTAEON) 
PLATE 11

Figures 1-4. Trochactaeon (Mexicotrochactaeon) coniformis (Bos̈e) (p. 56).

1. Axial section $(\times 2)$ of a specimen from the Cardenas Formation, State of San Luis Potosi, Mexico, at locality 157. USGS 28213; USNM 306060 .

2. Axial section $(\times 2.5)$ of a specimen from the same locality. USGS 28216 ; USNM 306061 .

3. Axial section $(\times 2.5)$ of a specimen from the same locality. USGS 28216 ; USNM 306062 .

4. Axial section $(\times 2.5)$ of a specimen from the same locality. USGS 28216 ; USNM 306057.

5. Trochactaeon (Mexicotrochactaeon) palmeri Sohl and Kollmann, n. sp. (p. 60).

Axial section $(\times 1.5)$ of a paratype from the "Titanosarcolites limestone" of the Jerusalem Mountain inlier, Jamaica, at locality 111. USGS 29466; USNM 306063.

6, 7, 10. Trochactaeon (Neocylindrites) nelsoni Sohl and Kollmann, n. sp. (p. 55).

6. Axial section $(\times 4)$ of a paratype from the Pozas Formation, Orocovis Quadrangle, Puerto Rico, at locality 28 . USGS 30534; USNM 306064.

7. Axial section $(\times 4)$ of a specimen from the Cotui Limestone, San German Quadrangle, Puerto Rico, at locality 40 . USGS 30347; USNM 306065.

10. Axial section $(\times 2)$ of a paratype from the Flor de Alba Limestone Lentil of Pozas Formation, Florida Quadrangle, Puerto Rico, at locality 22. USGS 28629; USNM 306066.

8, 9. Trochactaeon (Mexicotrochactaeon) wrighti Sohl and Kollmann, n. sp. (p. 59).

8. Axial section ( $\times 1.5$ ) of a paratype from the Cardenas Formation, State of San Luis Potosi, Mexico, at locality 152. USGS 24392; USNM 306067.

9. Axial section $(\times 2.5)$ of a paratype from the same locality. USGS 24392 ; USNM 306068.

11. Trochactaeon (Neocylindrites) sp. A. (p. 55).

Axial section $(\times 2.5)$ of a specimen from the El Rayo Formation, Sabana Grande Quadrangle, Puerto Rico, at locality 36. USGS 29075; USNM 306069. 


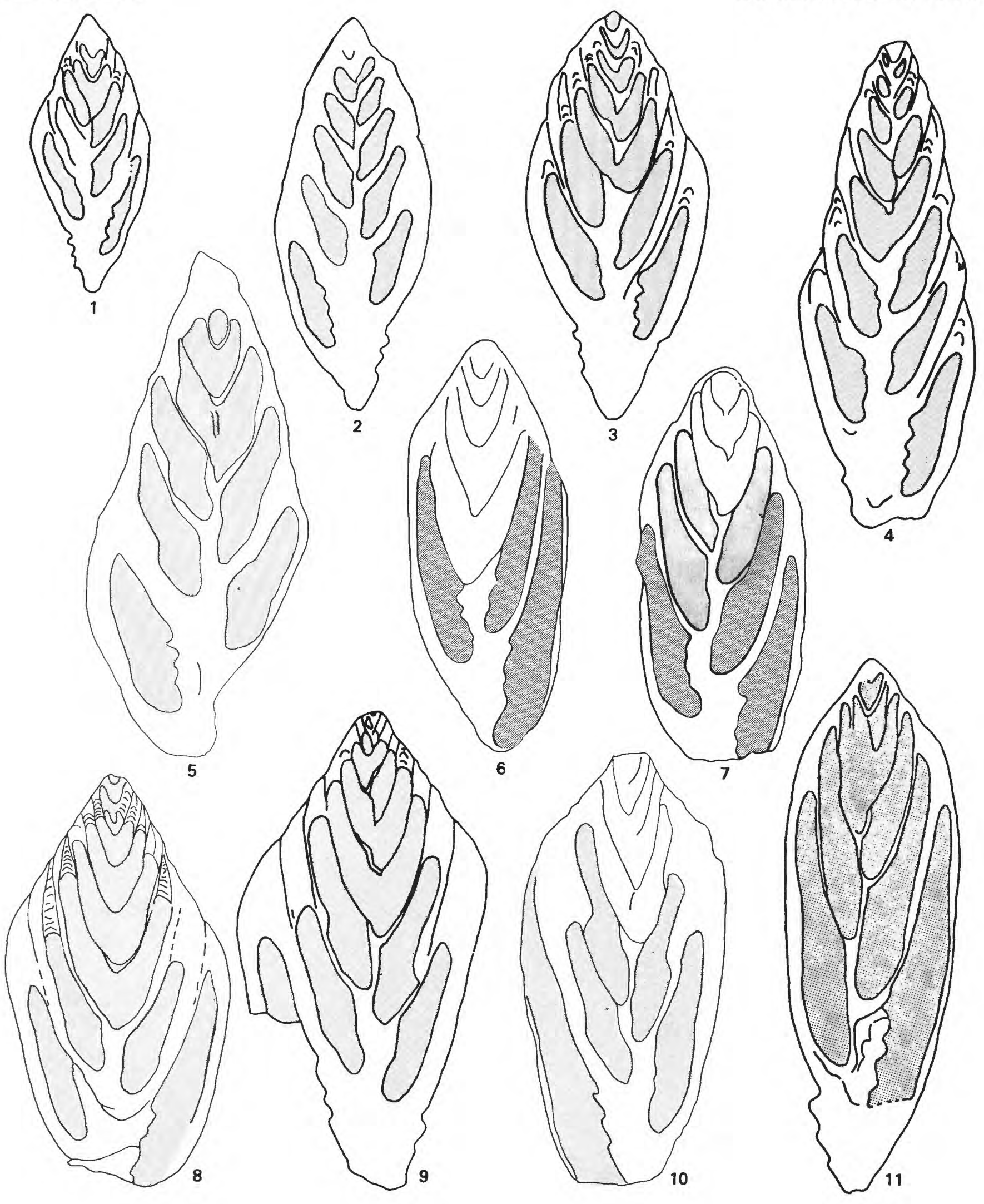

TROCHACTAEON (MEXICOTROCHACTAEON) AND T. (NEOCYLINDRITES) 


\section{PLATE 12}

Figures 1-6, 10. Trochactaeon (Mexicotrochactaeon) wrighti Sohl and Kollmann, n. sp. (p. 59).

1. Aperture view $(\times 1.5)$ of a paratype from the Cardenas Formation, State of San Luis Potosi, Mexico, at locality 152. USGS 24392; USNM 306070.

2. Aperture view $(\times 1)$ of a paratype from the same locality. USGS 24392; USNM 306071.

3. Axial section $(\times 1)$ of a paratype, showing (arrow) fold of palatal wall. Same locality. USGS 24392; USNM 306072.

4, 5. Back and aperture views $\left(\times 1 \frac{112}{2}\right)$ of the holotype from the same locality. USGS 24392; USNM 306073.

6. Axial section $\left(\times 1 \frac{1}{1} 2\right)$ of a paratype from the same locality. USGS 24392 ; USNM 306074 .

10. Aperture view $(\times 1)$ of a paratype from the "Titanosarcolites limestone," Marchmont inlier, Jamaica, at locality 99. USGS 30462; USNM 306075.

7-9, 11-13. Trochactaeon (Mexicotrochactaeon) burckhardti Böse (p. 58).

7, 9. Aperture and back views ( $\times 1$ ) of a specimen from the Maldon Limeston, Maldon inlier, Jamaica, at locality 119. USGS 29955; USNM 306076.

8. Axial section $(\times 1)$ of a specimen from the Guinea Corn Formation, Central inlier, Jamaica, at locality 64. USGS 29978; USNM 306077.

11. Back view $(\times 1)$ of a specimen from the Maldon Limestone, Maldon inlier, Jamaica, at locality 119. USGS 30018; USNM 306078.

12. Aperture view $(\times 1)$ of a specimen from the Guinea Corn Formation, Central inlier, Jamaica, at locality 67 . USGS 29981; USNM 306079.

13. Aperture view ( $\times 1$ ) of a specimen from the Maldon Limestone, Maldon inlier, Jamaica, at locality 119. USGS 30018; USNM 306080. 

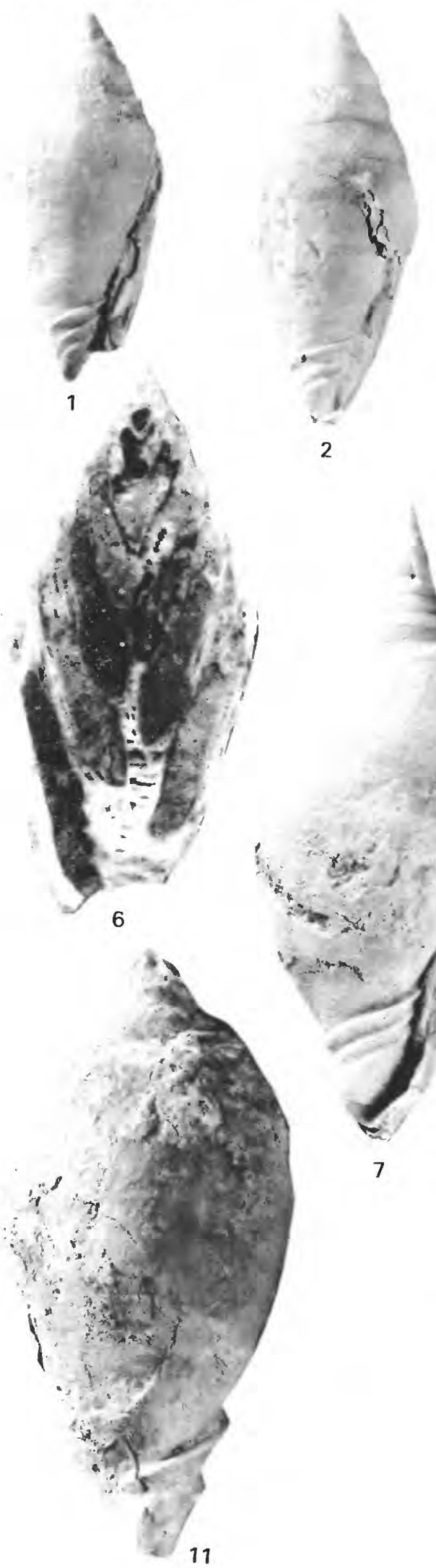

7
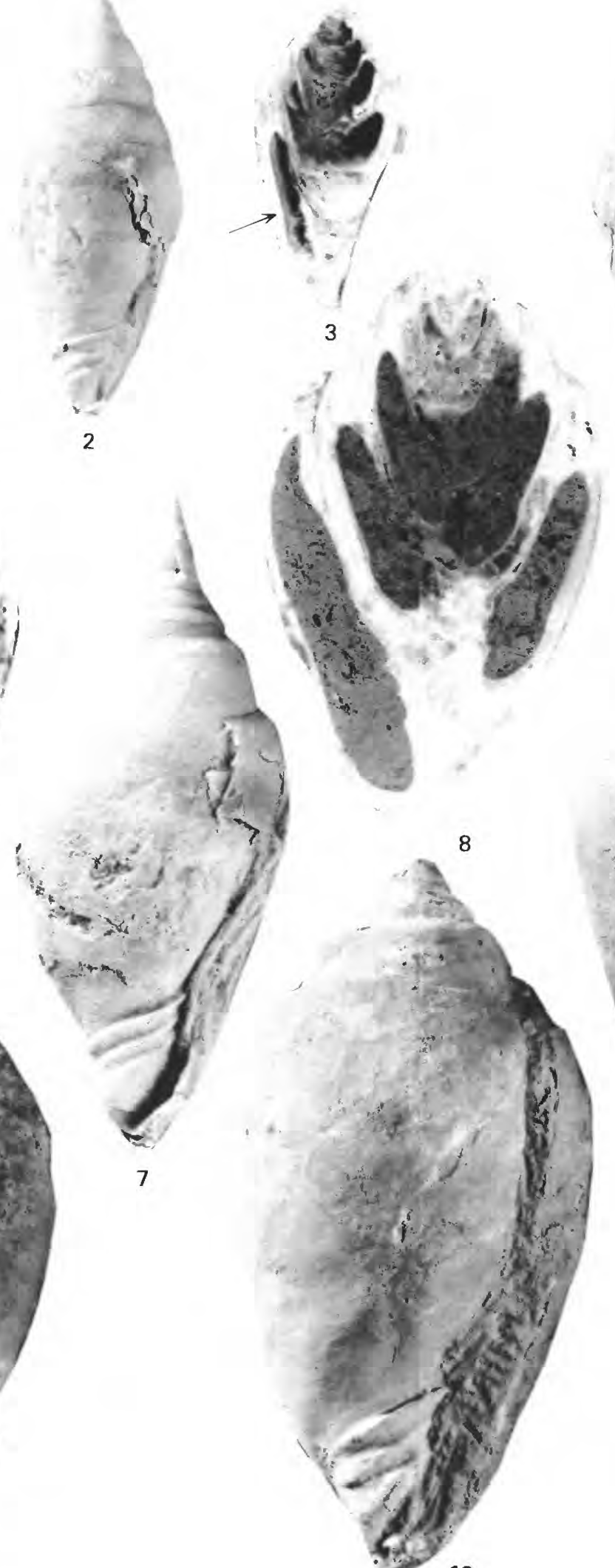


\section{PLATE 13}

FigURES 1-3, 6, 14. Trochactaeon (Mexicotrochactaeon) teaenis Sohl and Kollmann, n. sp. (p. 60).

1. Axial section $(\times 1)$ of a paratype from the Cardenas Formation, State of San Luis Potosi, Mexico, at locality 155. USGS 28187; USNM 306081.

2. Axial section $(\times 1)$ of a paratype from the Cardenas Formation, State of San Luis Potosi, Mexico, at locality 156. USGS 28218; USNM 306082.

3. Axial section $(\times 1)$ of a paratype from the "Titanosarcolites limestone," Jerusalem Mountain inlier, Jamaica, at locality 109. USGS 30011; USNM 306083.

6. Axial section $(\times 1)$ of a paratype from the same locality. USGS 30422 ; USNM 306084.

14. Axial section ( $\times 1.5$ ) of a paratype from the El Rayo Formation, San German Quadrangle, Puerto Rico, at locality 48. USGS 30354; USNM 306085.

4, 5. Trochactaeon (Mexicotrochactaeon) rossi Sohl and Kollmann, n. sp. (p. 62).

4. Axial section $(\times 1)$ of a paratype from the Guinea Corn Formation, Central inlier, Jamaica, locality 55. USGS 29454; USNM 306086.

5. Axial section $(\times 1)$ of a paratype from the "Titanosarcolites limestone," Marchmont inlier, Jamaica, at locality 99. USGS 30462; USNM 306087.

7-9. Trochactaeon (Mexicotrochactaeon) burckhardti Böse (p. 58).

7. Axial section $(\times 1)$ of a specimen from the Guinea Corn Formation, Central inlier, Jamaica, at locality 64 . USGS 29978; USNM 306088.

8. Axial section $(\times 1)$ of a specimen from the Maldon Limestone, Maldon inlier, Jamaica, at locality 119. USGS 29955; USNM 306089.

9. Axial section $(\times 1)$ of a specimen from the Guinea Corn Formation, Central inlier, Jamaica, at locality 58 . USGS 31487; USNM 306090.

10-13. Trochactaeon (Mexicotrochactaeon) granthamensis Sohl and Kollmann, n. sp. (p. 61).

10. Axial section $(\times 1)$ of a paratype from the Guinea Corn Formation, Central inlier, Jamaica, at locality 64, USGS 30044; USNM 306091.

11. Axial section $(\times 1)$ of a paratype from the Guinea Corn Formation, Central inlier, Jamaica, at locality 60 a. USGS 30043; USNM 306092.

12. Axial section $(\times 1)$ of a paratype from the Guinea Corn Formation, Central inlier, Jamaica, at locality 68. USGS 29982; USNM 306093.

13. Axial section $(\times 1)$ of a paratype from the Guinea Corn Formation, Central inlier, Jamaica, at locality 69 . USGS 29987; USNM 306094. 

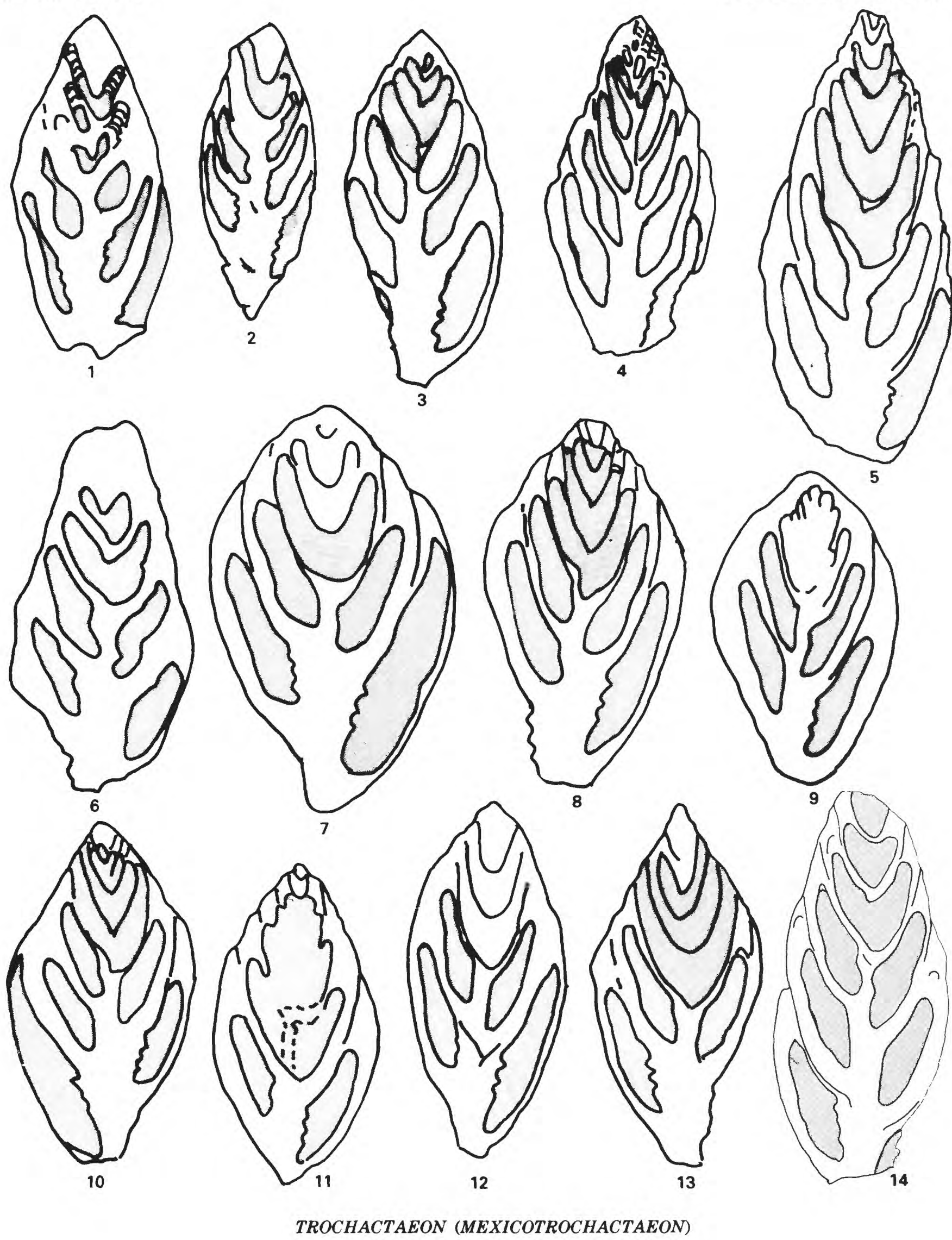


\section{PLATE 14}

Figures 1-5, 8. Trochactaeon (Mexicotrochactaeon) palmeri Sohl and Kollmann, n. sp. (p. 60).

1. Aperture view $(\times 1)$ of a paratype from the "Titanosarcolites limestone," Jerusalem Mountain inlier, Jamaica, at locality 108. USGS 30421; USNM 306095.

2. Back view $(\times 1)$ of a paratype from the same locality. USGS 30421 ; USNM 306096.

3. Aperture view $(\times 1)$ of a paratype from the Habana Formation, Santa Clara Province, Cuba, at locality 129. USGS 27278; USNM 306097.

4. Aperture view $(\times 1)$ of the holotype from the Guinea Corn Formation, Central inlier, Jamaica, at locality 65. USGS 29979; USNM 306098.

5. Aperture view $(\times 1)$ of a specimen from the Habana Formation, Santa Clara Province, Cuba, at locality 129. USGS 27278; USNM 306099.

8. Axial section $(\times 2)$ of a paratype from the El Rayo Formation, San German Quadrangle, Puerto Rico, at locality 42. USGS 31488; USNM 306100.

6, 7, 9-16. Trochactaeon (Mexicotrochactaeon) teaensis Sohl and Kollmann, n. sp. (p. 60).

6, 7. Back and front views $(\times 1)$ of a paratype from the El Rayo Formation, San German Quadrangle, Puerto Rico, at locality 48. USGS 30354; USNM 306101.

9, 10. Aperture and back views $(\times 1)$ of a paratype from the same locality. USGS 30354; USNM 306102.

11. Back view $(\times 1)$ of a paratype from the same locality. USGS 30354 ; USNM 306103.

12. Axial section $(\times 1.5)$ of a paratype from the same locality. USGS 30354; USNM 306104.

13. Aperture view $(\times 1.5)$ of the holotype from the same locality, USGS 30354; USNM 306105 .

14. Axial section $(\times 1)$ of a paratype from the "Titanosarcolites limestone," Jerusalem Mountain inlier, Jamaica, at locality 109. USGS 30422; USNM 306106.

15. Aperture view $(\times 1)$ of a paratype from the Cardenas Formation, State of San Luis Potosi, Mexico, at locality 156. USGS 28218; USNM 306107.

16. Aperture view $(\times 1)$ of a paratype from the "Titanosarcolites limestone," Jerusalem Mountain inlier, Jamaica, at locality 109. USGS 30011; USNM 306108. 

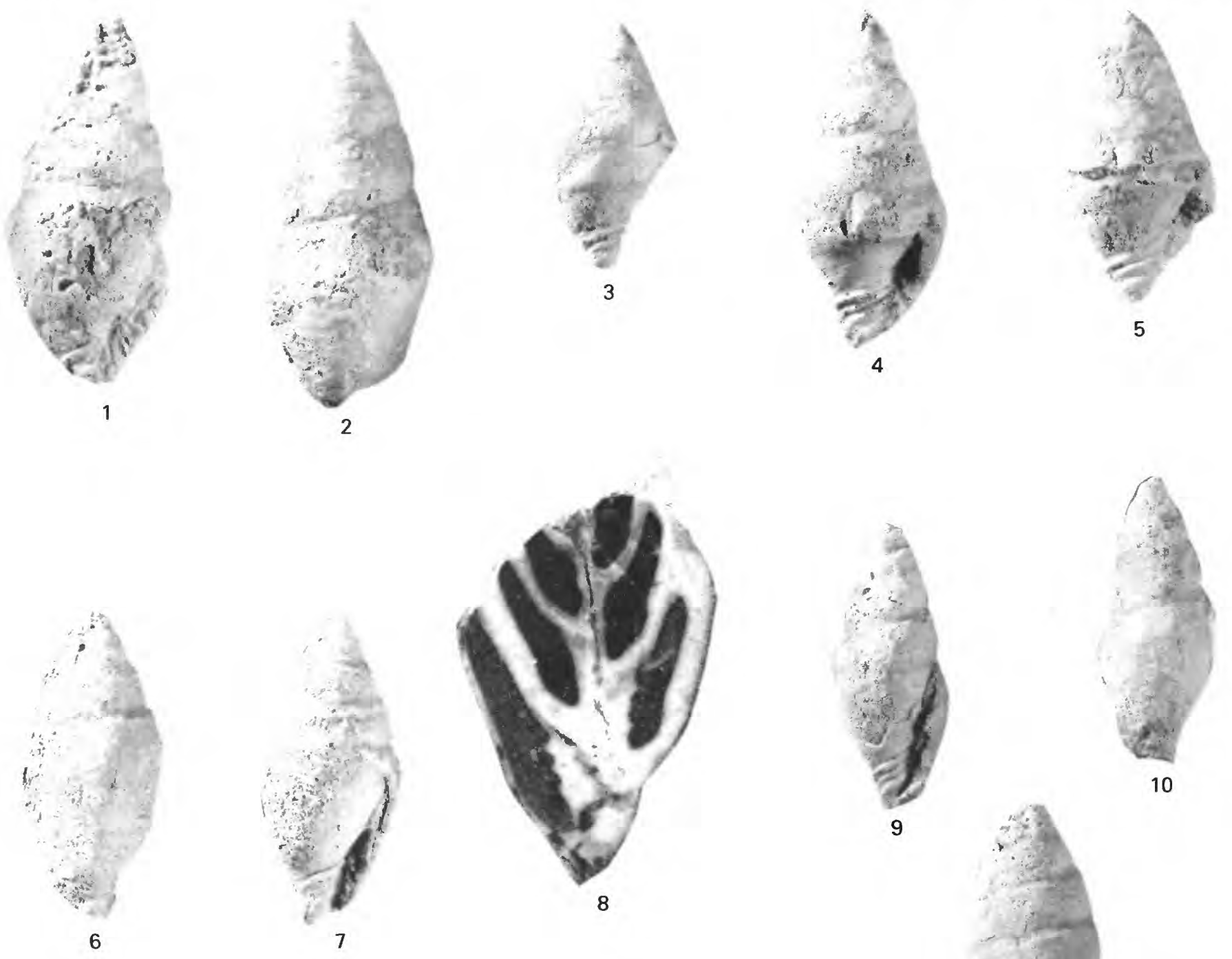

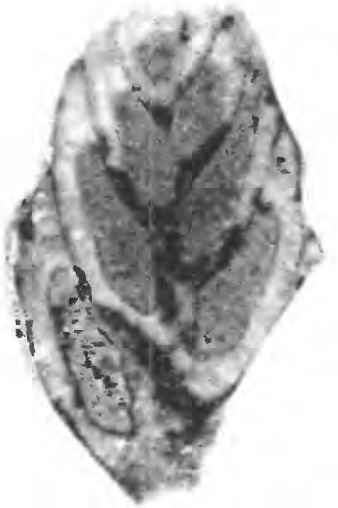

12

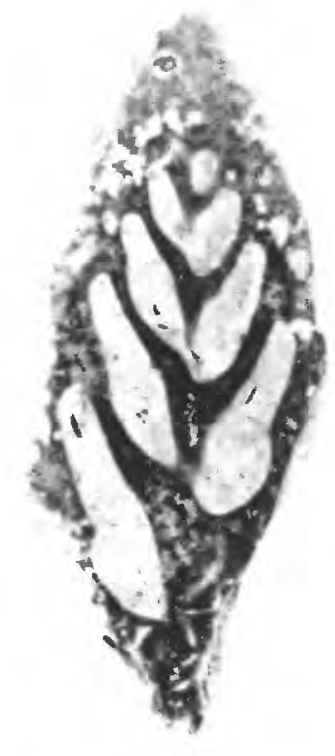

14
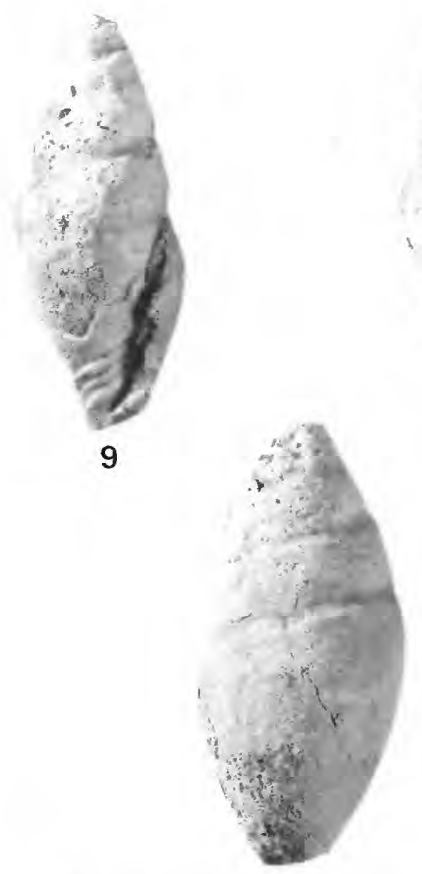

11

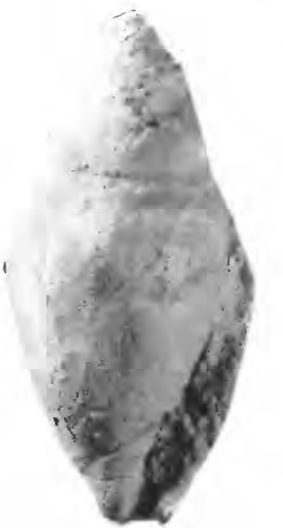

15

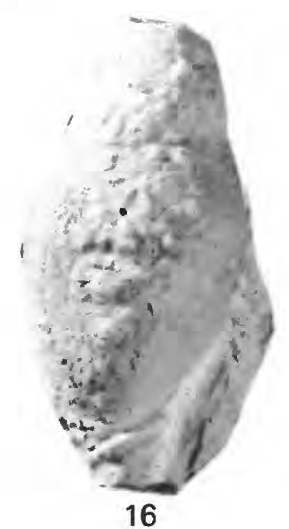

TROCHACTAEON (MEXICOTROCHACTAEON) 


\section{PLATE 15}

Figures 1-11. Trochactaeon (Mexicotrochactaeon) granthamensis Sohl and Kollmann, n. sp. (p. 61).

1. Axial section $(\times 1)$ of a paratype from the Guinea Corn Formation, Central inlier, Jamaica, at locality 64 . USGS 30044; USNM 306091.

2. Aperture view $(\times 1)$ of a paratype from the same locality, showing the nature of the inner lip callus. USGS 30044; USNM 306108.

3. Aperture view $(\times 1)$ of a small paratype from the same locality. USGS 30044; USNM 306109 .

4. Aperture view $(\times 1)$ of a paratype from the same locality, which has a proportionally low spire. USGS 30044; USNM 306110.

5. Back view $(\times 1)$ of a paratype from the same locality. USGS 30044; USNM 306111

6, 7. Front and back views $(\times 1)$ of a paratype from the Guinea Corn Formation, Central inlier, Jamaica, at locality 68a. USGS 29985; USNM 306112.

8. Side view $(\times 1)$ of a paratype, showing repair of a shell breakage. Guinea Corn Formation, Central inlier, Jamaica, at locality 64. USGS 30044; USNM 306113.

9. Axial section $(\times 1)$ of a specimen from the same locality. USGS 30044; USNM 306114.

10,11 . Aperture and side view $(\times 1)$ of the holotype from the same locality. USGS 30044; USNM 306115. 

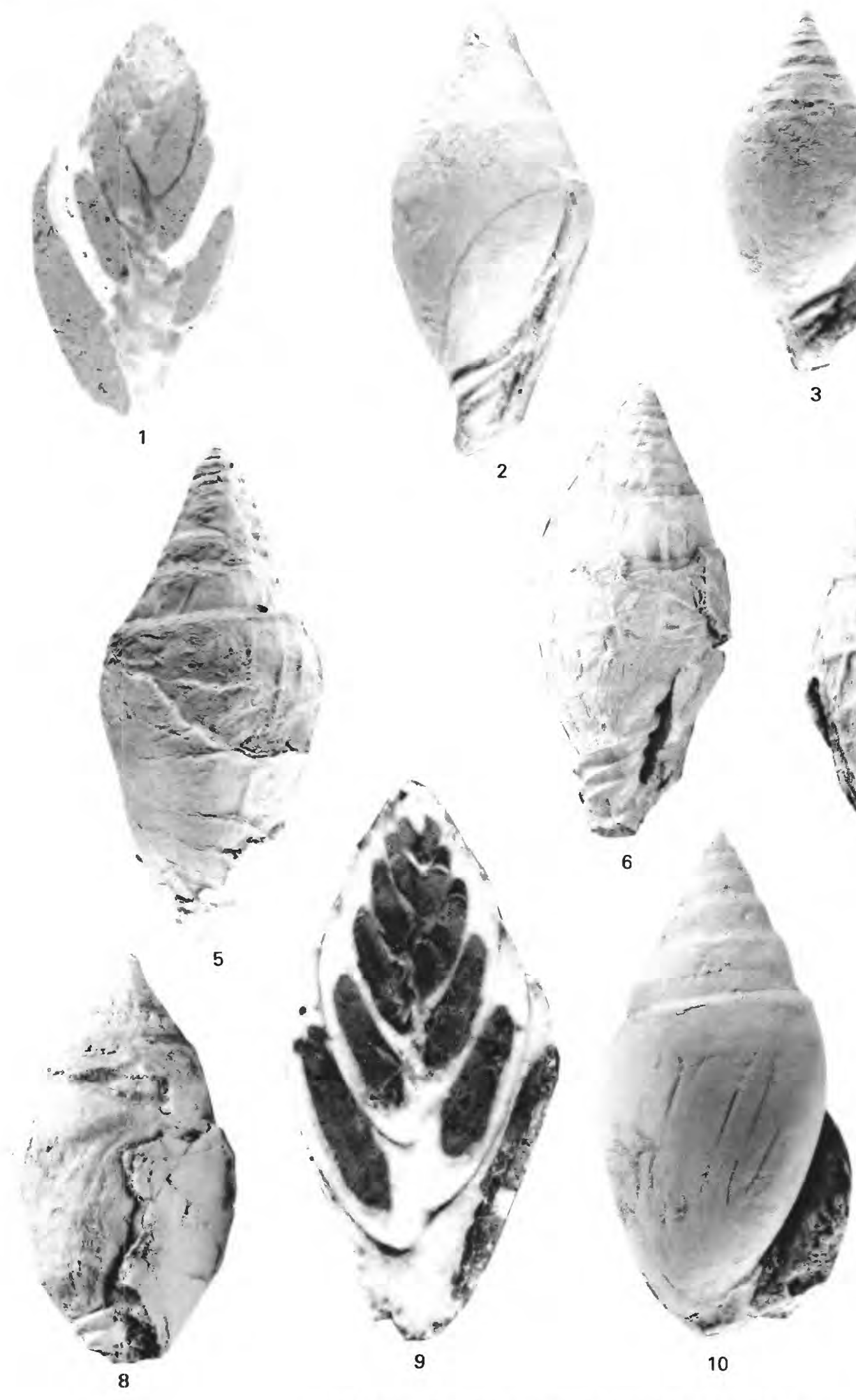

10

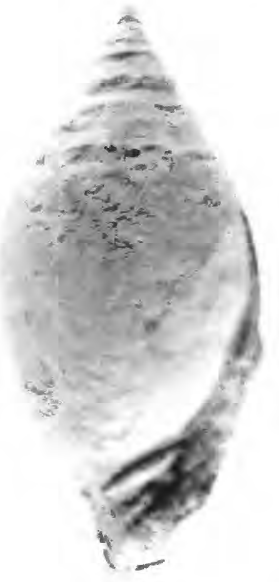

3
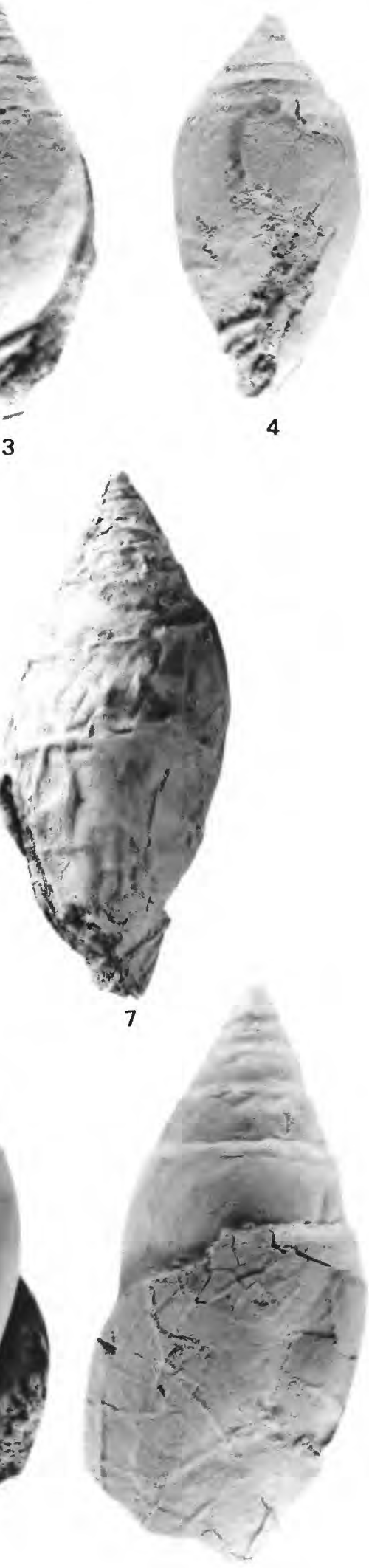

11

TROCHACTAEON (MEXICOTROCHACTAEON) 


\section{PLATE 16}

Figures 1-9. Trochactaeon (Mexicotrochactaeon) rossi Sohl and Kollmann, n. sp. (p. 62).

1, 2. Back and aperture views $(\times 1)$ of a specimen figured by Myers (1968, pl. 7, fig. 4) as Actaeonella coniformis Böse. UT (WSA) 15585.

3. Aperture view $(\times 1)$ of a paratype from the "Titanosarcolites limestone," Marchmont inlier, Jamaica, at locality 99. USGS 30462; USNM 306116.

4, 5. Back and aperture views $(\times 1)$ of a paratype from the same locality. USGS 30462; USNM 306117.

6. Axial section $(\times 1)$ of a paratype from the same locality. USGS 30462; USNM 306118.

7. Aperture view $(\times 1)$ of a paratype from the Guinea Corn Formation, Central inlier, Jamaica, at locality 78 . USGS 30141; USNM 306119

8, 9. Back and front views $(\times 1)$ of the holotype from the "Titanosarcolites limestone," Marchmont inlier, Jamaica, at locality 99. USGS 30462; USNM 306120.

10-13. Trochactaeon (Mexicotrochactaeon) melonensis Sohl and Kollmann, n. sp. (p. 63)

10, 11. Back and front views ( $\times 1$ ) of a paratype from the Melones Limestone, Cabo Rojo Quadrangle, Puerto Rico, at locality 13. USGS 30565; USNM 306121.

12. Axial section $(\times 1.5)$ of a paratype from the Melones Limestone, Puerto Real Quadrangle, Puerto Rico, at locality 33. USGS 29354; USNM 306122.

13. Aperture view of the holotype $(\times 1)$ from the Melones Limestone, Cabo Rojo Quadrangle, Puerto Rico, at locality 13. USGS 30565; USNM 306123. 


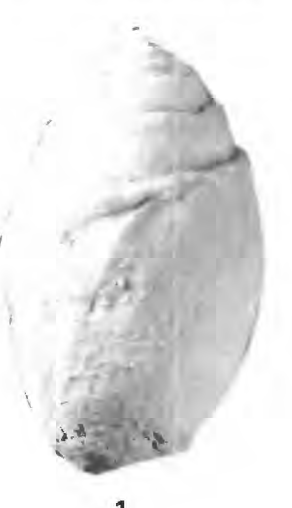

1
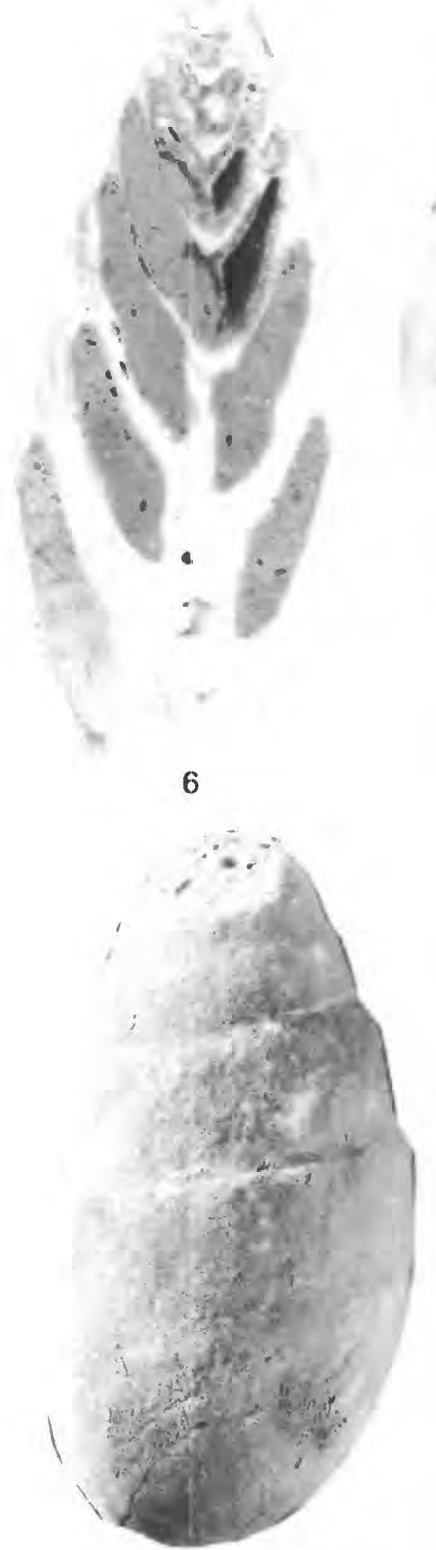

10
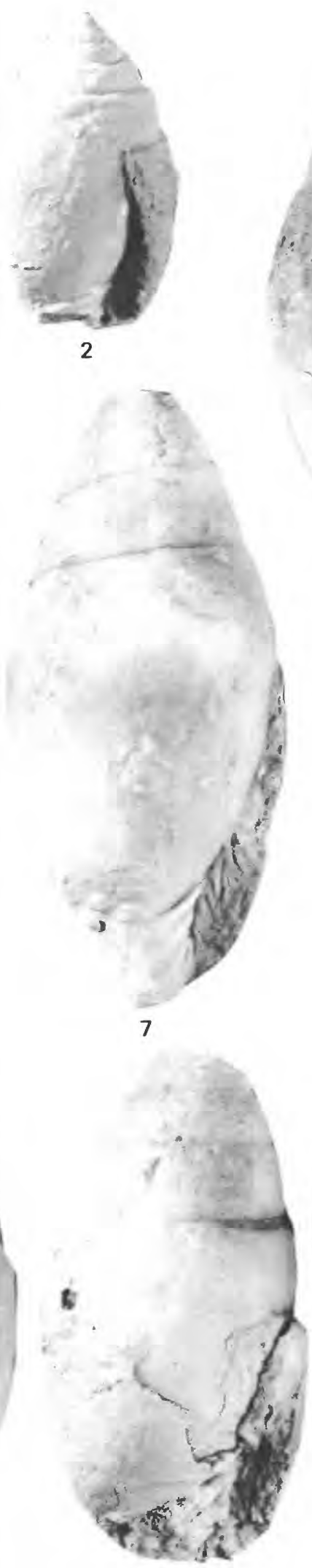

11
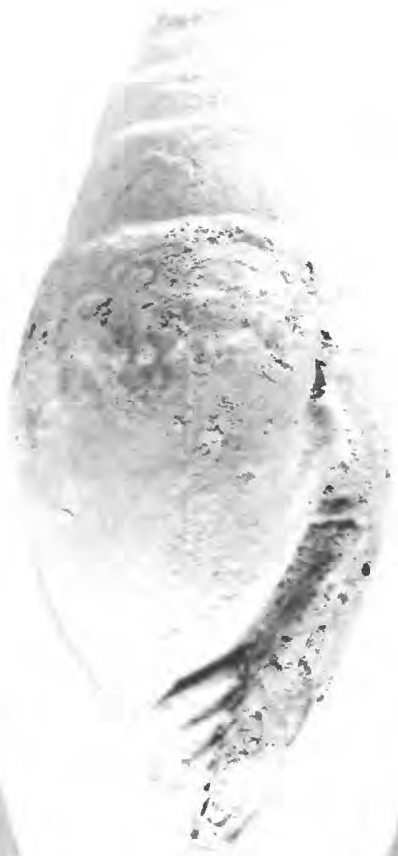

3
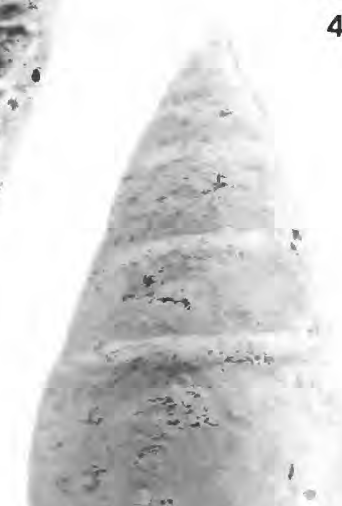

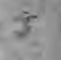
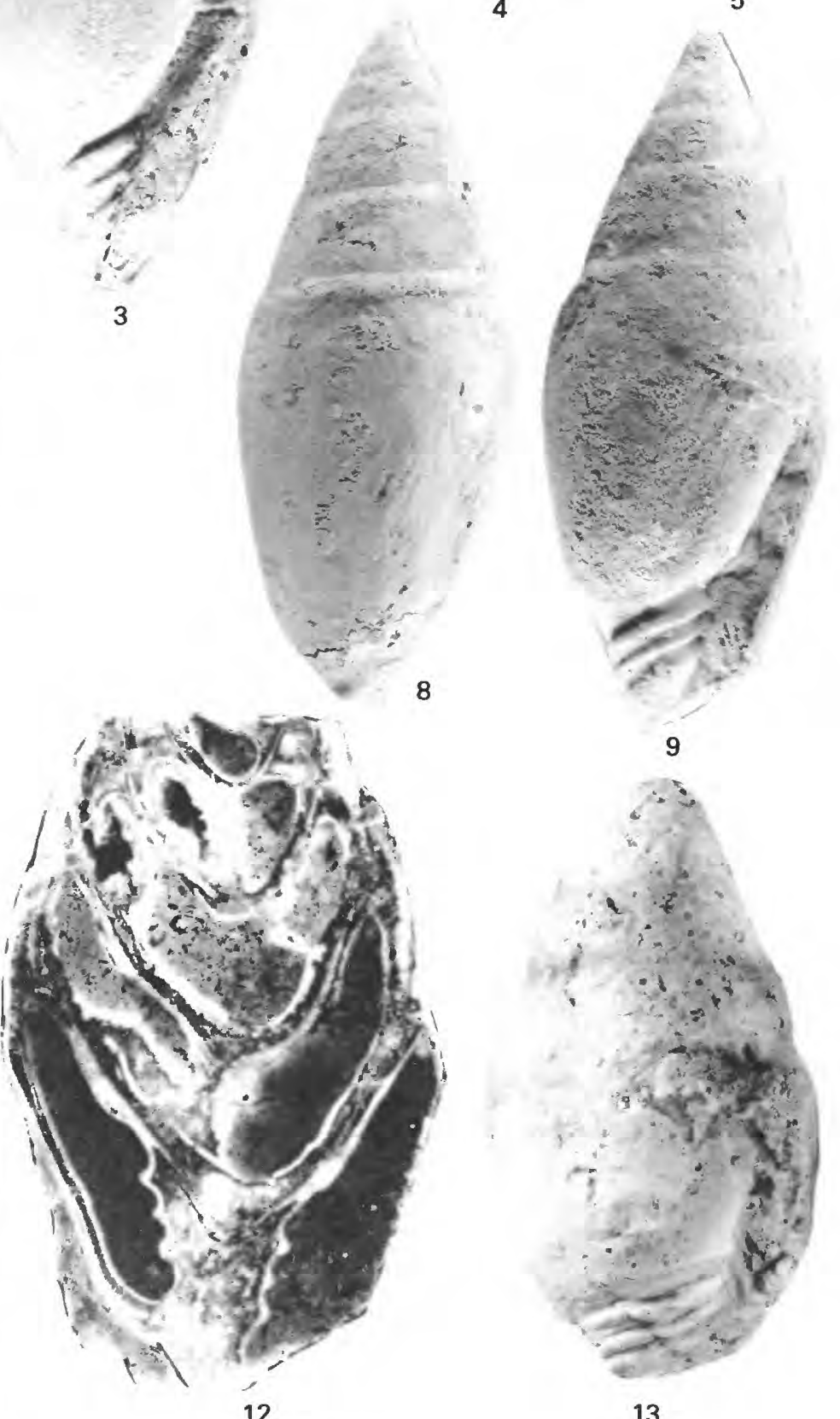

12

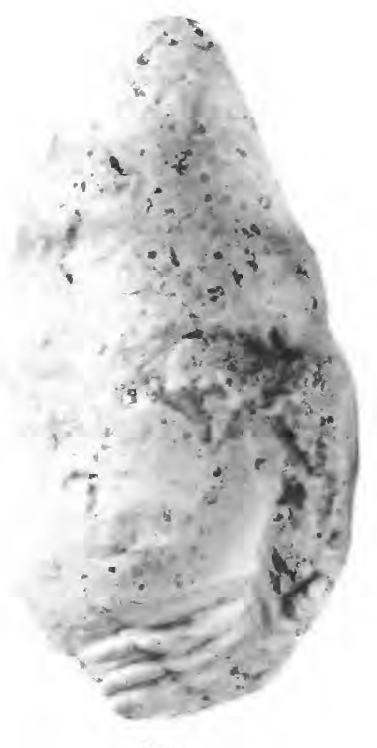

13

TROCHACTAEON (MEXICOTROCHACTAEON) 
PLATE 17

Figures 1, 4, 5. Actaeonella robinsoni Sohl and Kollmann, n. sp. (p. 73).

1. Axial section $\left(\times 1 \frac{1}{2}\right)$ of a paratype from the Guinea Corn Formation, Central inlier, Jamaica, at locality 69 . USGS 29987; USNM 306124.

4. Axial section $\left(\times 1 \frac{1 / 2}{2}\right)$ of a paratype from the same locality. USGS 29987 ; USNM 306125.

5. Axial section $(\times 2)$ of a paratype from the same locality. USGS 29987 ; USNM 306126.

2. Actaeonella cubensis Kollmann and Sohl, n. sp. (p. 72).

Axial section $(\times 3)$ of a paratype from the Habana(?) Formation, Oriente Province, Cuba, at locality 125. USGS 19465. USNM 306127 .

3. Actaeonella n. sp. A. (p. 73).

Axial section $(\times 1 / 2)$ of a specimen from the Maravillas Formation, Coamo Quadrangle, Puerto Rico, at locality 19. USGS 26834; USNM 306128.

6-8. Trochactaeon (Mexicotrochactaeon) melonensis Sohl and Kollmann, n. sp. (p. 63).

6. Axial section ( $\times 1 \frac{11 / 2}{2}$ of a paratype from the Melones Limestone, Cabo Rojo Quadrangle, Puerto Rico, at locality 13. USGS 30565; USNM 306122.

7. Axial section ( $\times 11^{1 / 2}$ ) of a paratype from the same locality. USGS 30565; USNM 306129.

8. Axial section $\left(\times 1 \frac{1 / 2}{2}\right)$ of a paratype from the same locality. USGS 30565; USNM 306130. 


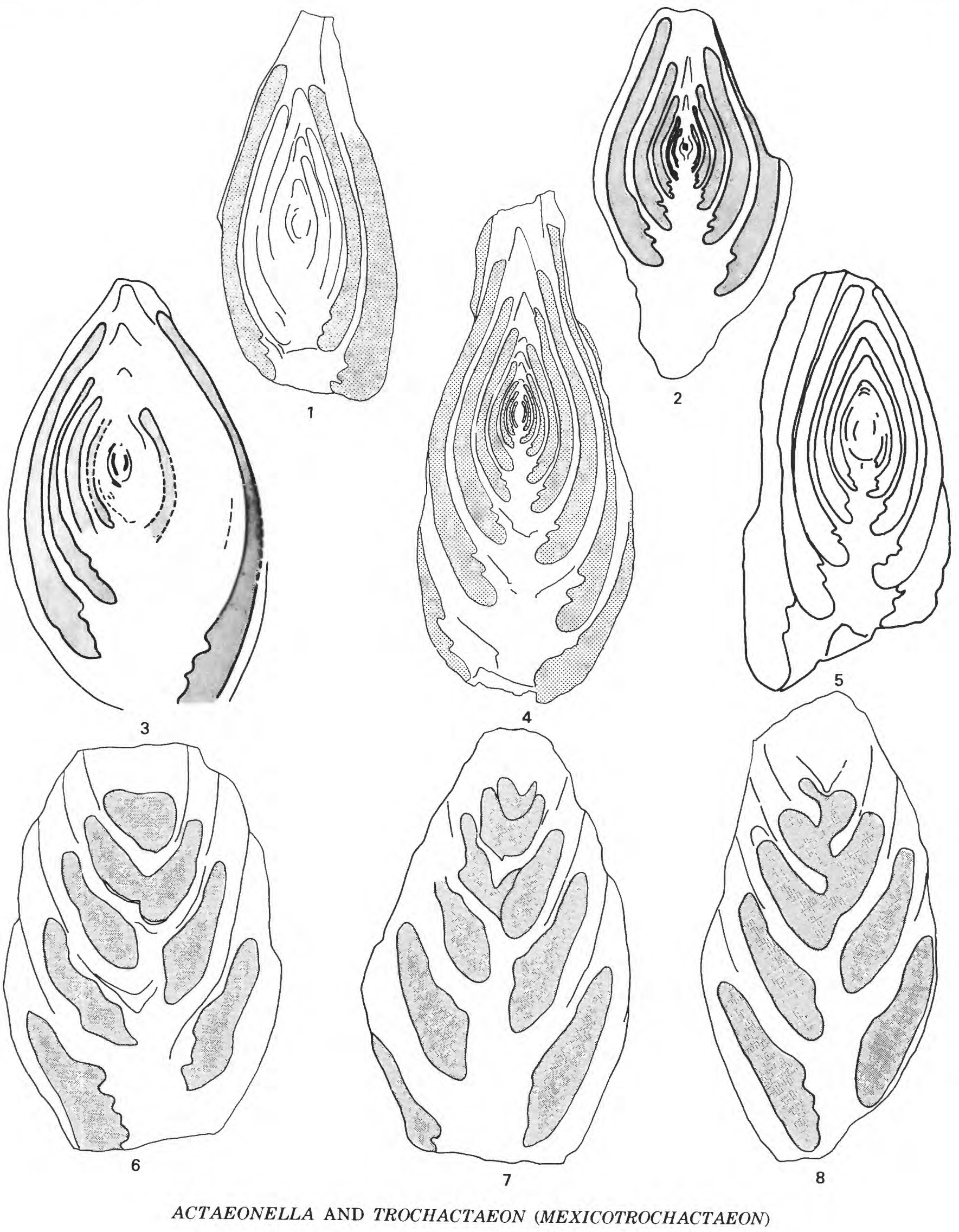




\section{PLATE 18}

Figures 1-8. Actaeonella browni Sohl and Kollmann, n. sp. (p. 67).

1, 2. Back and aperture views $(\times 2)$ of the holotype from Albian Limestone, Peten, Guatemala, at locality 160. USGS 28327; USNM 306131.

3. Back view $(\times 2)$ of a paratype from the same locality. USGS 28327 ; USNM 306132.

4. Aperture view $(\times 2)$ of an incomplete paratype from the same locality. USGS 28327 ; USNM 306133.

5. Back view $(\times 1)$ of a paratype from the same locality. USGS 28327 ; USNM 306134.

6. Aperture view $(\times 2)$ of a paratype from the same locality. USGS 28327; USNM 306135.

7. Aperture view $(\times 2)$ of a paratype from the same locality. USGS 28327; USNM 306136.

8. Aperture view $(\times 2)$ of a paratype from the same locality. USGS 28327 ; USNM 306137.

9-14. Actaeonella pecosensis Stanton (p. 65).

9. Aperture view $(\times 6)$ of a small specimen from the Edwards Limestone of Williamson County, Tex., at locality 146. 146. UT 1036TX6.

10. Back view ( $\times 1$ ) of a paratype from the Devils River Limestone, Kinney County, Tex., locality 139. USGS 11885; USNM 77561a.

11. Back view $(\times 2)$ of a specimen from the Devils River Limestone, Val Verde County, Tex., at locality 134. USGS 1941; USNM 306138.

12 13. Back and aperture views $\left(\times 1 \frac{11}{2}\right)$ of the holotype from the same locality. USGS 1941; USNM 77560.

14. Axial section $\left(\times 1 \frac{112}{2}\right)$ of specimen from the same locality. USGS 1941 ; USNM 306139.

15, 16. Actaeonella oviformis Gabb (p. 68).

Back and aperture views $(\times 1)$ of the holotype from Cottonwood Creek, Shasta County, Calif. ANSP 4323.

17-20. Actaeonella delgadoi (Choffat) (p. 66).

17-20. Aperture views $(\times 2)$ of specimens from the Walnut Formation at unspecified localities in Texas. Renfro collection. USNM 306140, 306141, 306142, 306143.

21, 22. Actaeonella cf. A. sublaevis Briart and Cornet (p. 66).

21. Aperture view $(\times 1)$ of a specimen near Kent, Culberson County, Tex., at locality 133. USGS 1926; USNM 306144.

22. Back view $(\times 1)$ of an incomplete specimen from the Edwards Limestone of Williamson County, Tex., at locality 146. UT 1036 TX5. 

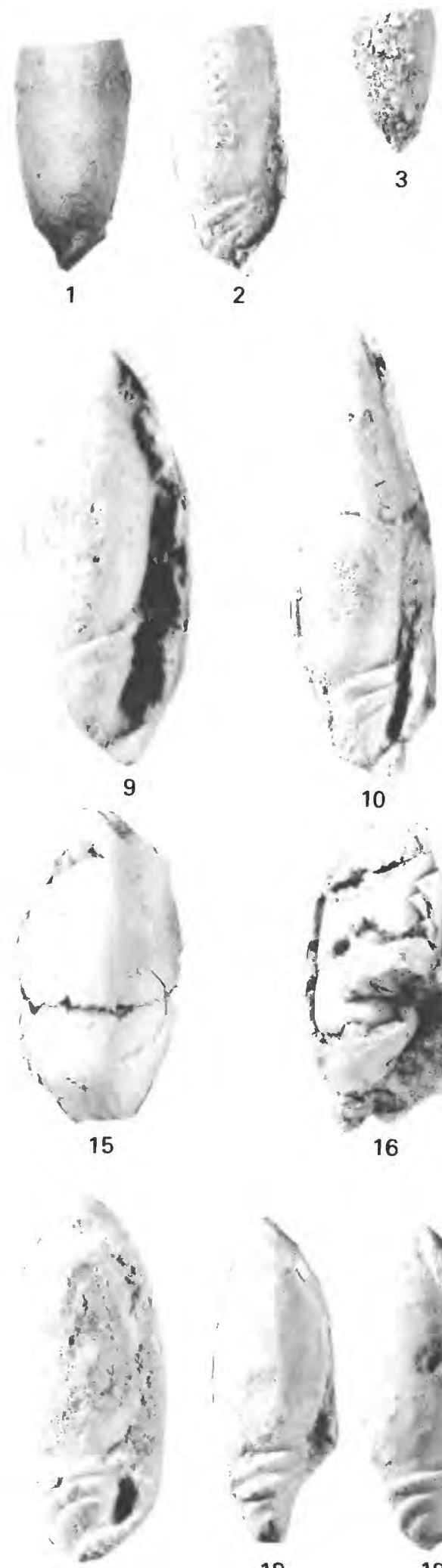

17
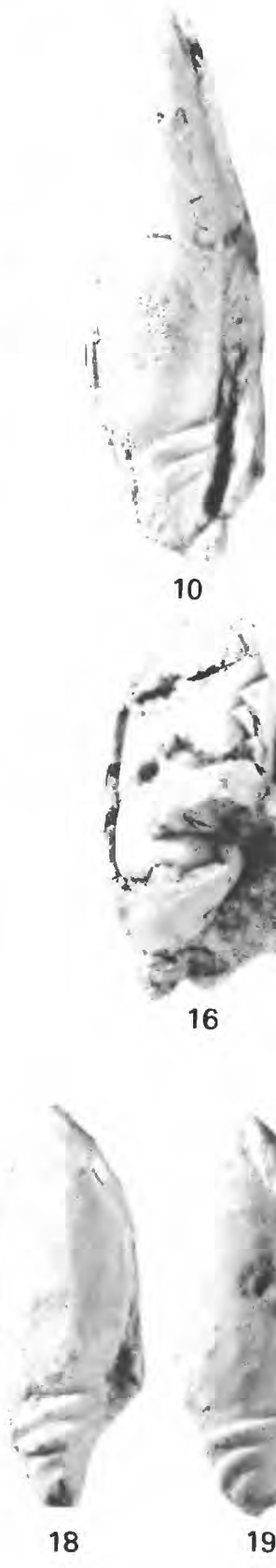
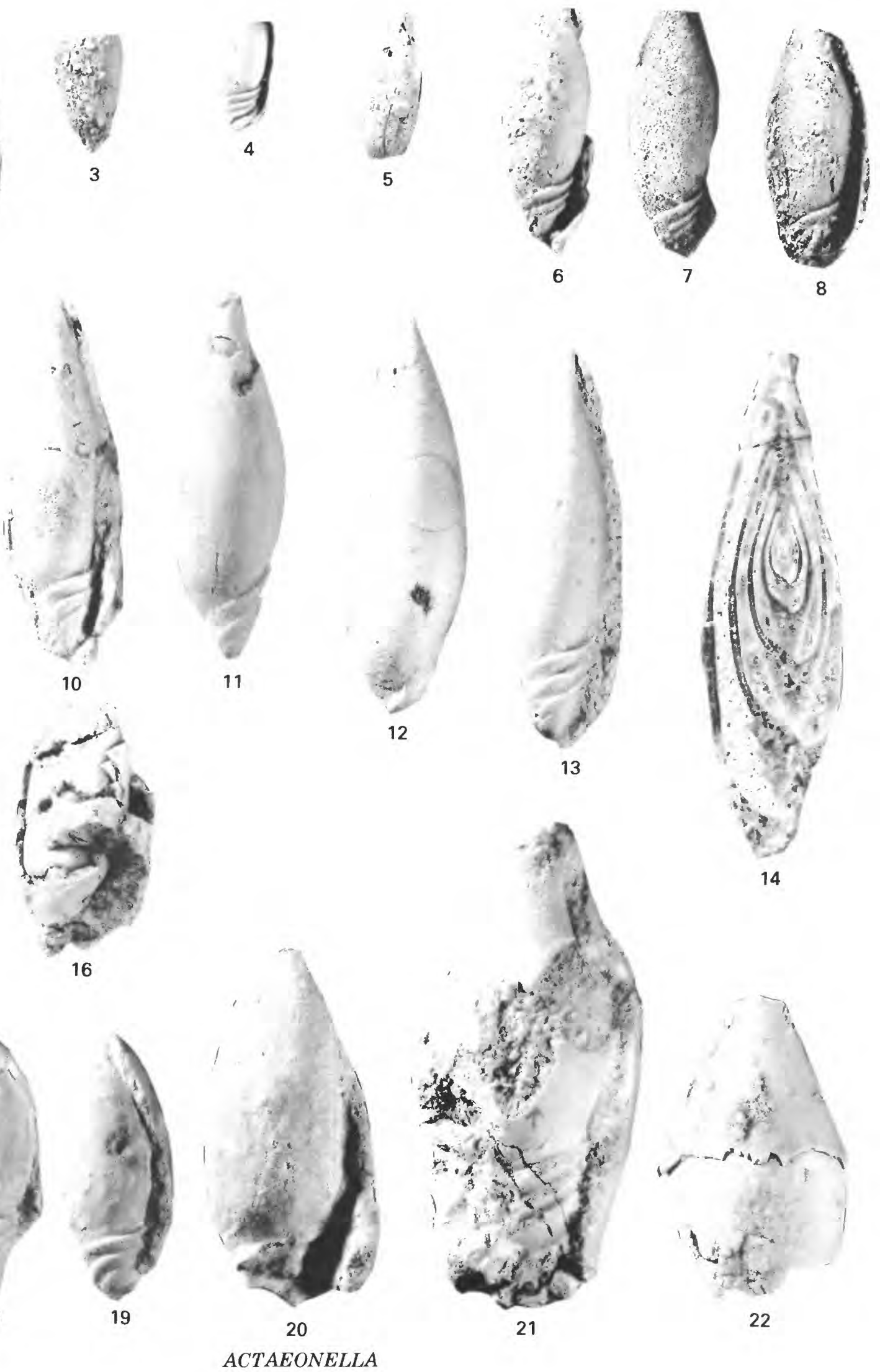

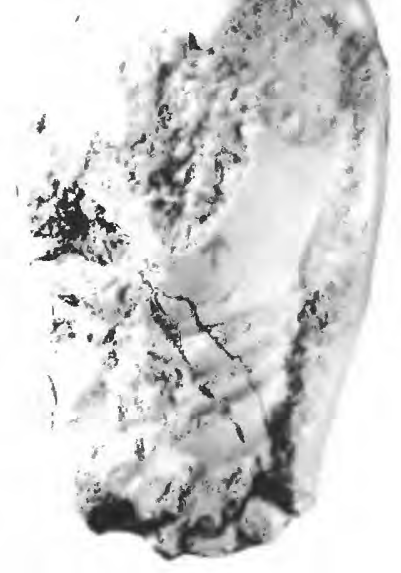

21

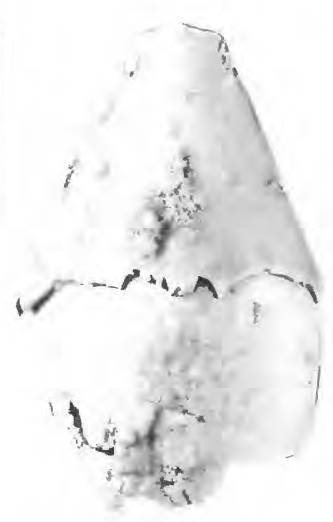

22 


\section{PLATE 19}

Figures 1-8. Actaeonella duckettsensis Sohl and Kollmann, n. sp. (p. 69).

1. View $(\times 1)$ of incomplete paratype from the Guinea Corn Formation, Central inlier, Jamaica, at locality 62 . USGS 29973; USNM 306145.

2. Axial section ( $\times 1 \frac{112}{2}$ ) of a paratype from the "Barrettia Limestone," Green island inlier, Jamaica, at locality 121. USGS 30007; USNM 306146 .

3. Aperture view $\left(\times 1 \frac{1}{2}\right)$ of a compressed paratype from the "Titanosarcolites limestone," Marchmont inlier, Jamaica, at locality 97. USGS 30026; USNM 306147.

4. Aperture view $\left(\times 1 \frac{1}{2}\right)$ of a paratype from the same locality. USGS 30026 ; USNM 306148.

5. Aperture view $(\times 1)$ of a paratype from the same locality. USGS 30026 ; USNM 306149.

6, 7, 8. Aperture, back, and basal view $\left(\times 1^{1 / 1}\right)$ of the holotype from the "Titanosarcolites limestone," Marchmont inlier, Jamaica, at locality 106. USGS 30455; USNM 306150.

9-15. Actaeonella jicarensis Sohl and Kollmann, n. sp. (p. 69).

9, 10. Back and aperture views $(\times 2)$ of a paratype from the El Rayo Formation, Sabana Grande Quadrangle, Puerto Rico, at locality 36 . USGS 28664; USNM 306151.

11. Back view $(\times 2)$ of a paratype from the same locality. USGS 28664 ; USNM 306152.

12, 13. Aperture and front views $(\times 3)$ of a paratype from the same locality. USGS 28664; USNM 306153.

14. Aperture view $(\times 2)$ of the holotype from the same locality. USGS 28664 ; USNM 306154 .

15. Axial section $(\times 3)$ of a paratype from the same locality. USGS 28664 ; USNM 306155.

16-21. Actaeonella borneensis Nuttall and Leong (p. 67).

16. Axial section $(\times 1)$ of a specimen from near Ocozocuautla, State of Chiapas, Mexico, at locality 150. USNM 306156.

17. Aperture view $(\times 1)$ of a specimen from near Ocozocuautla, State of Chiapas, Mexico, at locality 149. USNM 306157.

18. Aperture view $(\times 1)$ of a specimen from the same locality. USNM 306158.

19. Axial section $(\times 1)$ of a specimen from Santa Clara Province, Cuba, at locality 130. USGS 27295; USNM 306159.

20. View $(\times 1)$ of an incomplete specimen from near Ocozocuatla, State of Chiapas, Mexico, at locality 149. USNM 306160.

21. Axial section $(\times 1)$ of a specimen from the same locality. USNM 306161 . 
GEOLOGICAL SURVEY

PROFESSIONAL PAPER 1304 PLATE 19
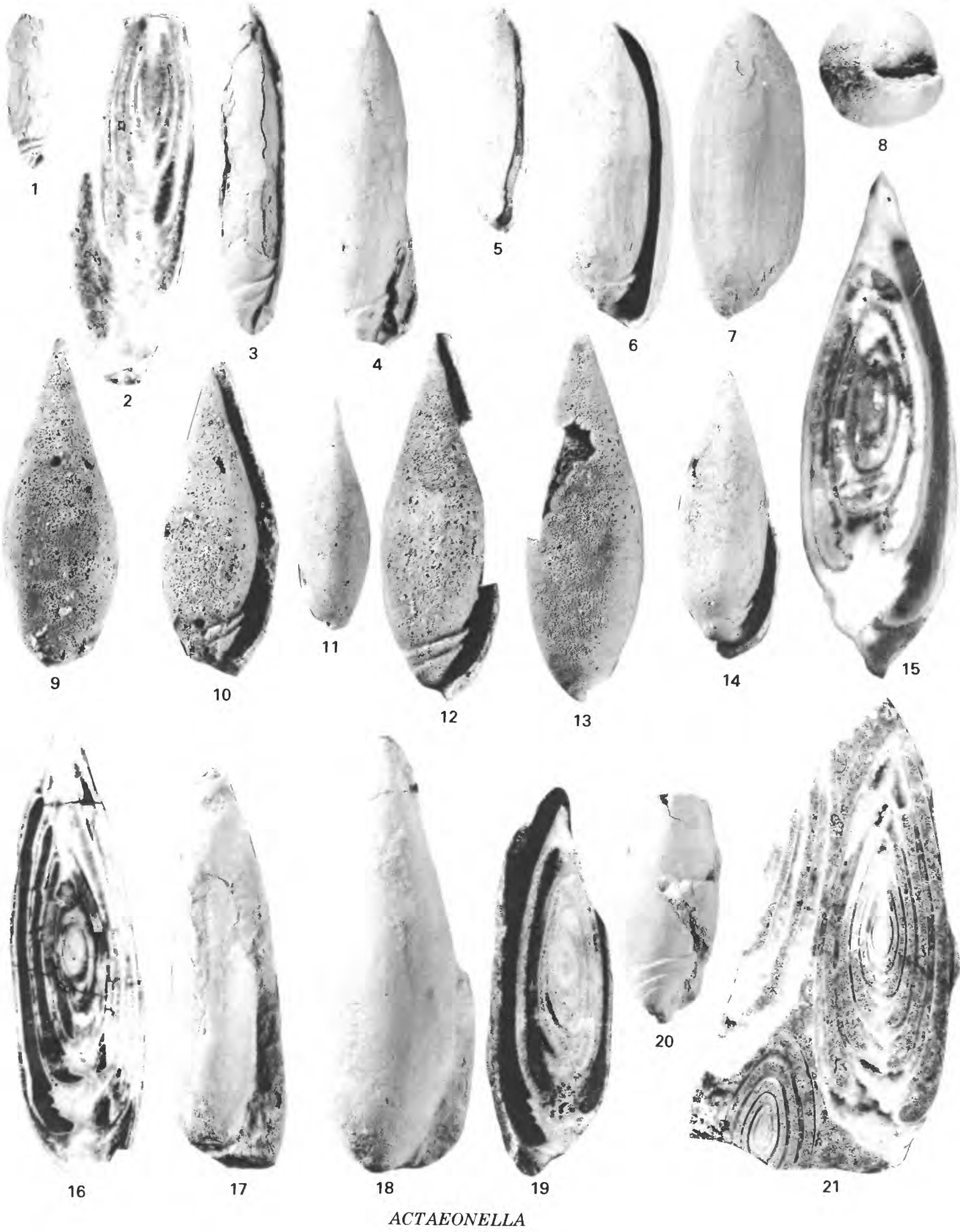


\section{PLATE 20}

Figures 1, 2, 5, 8. Actaeonella coquiensis Sohl and Kollmann, n. sp. (p. 70).

1. Axial section $(\times 4)$ of a paratype from the Coamo Formation of Berryhill and Glover (1960), Central Aguirre Quadrangle, Puerto Rico, at locality 16. USGS 29090; USNM 306162.

2. Axial section $(\times 3)$ of a paratype from the same locality. USGS 29090 ; USNM 306163.

5. Axial section $\left(\times 2 \frac{1}{1 / 2}\right)$ of a paratype from the Stapleton Formation, Sunderland inlier, Jamaica, at locality 122. USGS 30014; USNM 306164.

8. Axial section $\left(\times 2 \frac{1}{2}\right)$ of a paratype from Coamo Formation of Berryhill and Glover (1960), Central Aguirre Quadrangle, Puerto Rico, at locality 16. USGS 29090; USNM 306204.

3, 6. Actaeonella duckettsensis Sohl and Kollmann, n. sp. (p. 69).

3. Axial view of a paratype $\left(\times 1 \frac{112}{2}\right)$ from the "Barrettia Limestone," Green Island inlier, Jamaica, at locality 121 . USGS 30007; USNM 306146.

6. Axial view of a paratype $(\times 4)$ from the Slippery Rock Formation, Central inlier, Jamaica, at locality 53. USGS 30032; USNM 306165

4. Actaeonella briggsi Sohl and Kollmann, n. sp. (p. 72).

Axial view of a specimen from the Pozas Formation, Barranquitas Quadrangle, Puerto Rico, at locality 4. USGS 29365; USNM 306166.

7. Actaeonella jicarensis Sohl and Kollmann, n. sp. (p. 69).

Axial view $(\times 3)$ of a paratype from the El Rayo Formation, Sabana Grande Quadrangle, Puerto Rico, at locality 36. USGS 28664; USNM 306155.

9. Actaeonella cf. A. coquiensis Sohl and Kollmann (p. 71).

Axial view of a specimen ( $\times 1.25$ ) from the Melones Limestone, Puerto Real Quadrangle, Puerto Rico, at locality 32. USGS 30537; USNM 306167.

10. Actaeonella pecosensis Stanton (p. 65).

Axial view $\left(\times 1 \frac{1}{2}\right)$ of a specimen from the Devils River Limestone, Val Verde County, Tex., at locality 134. USGS 1941; USNM 306139.

11. Actaeonella borneensis Nuttall and Leong (p. 67).

Axial section $(\times 1.25)$ of a specimen from the upper Rancho Nuevo Beds, State of Chiapas, Mexico, at locality 149. USNM 306161. 


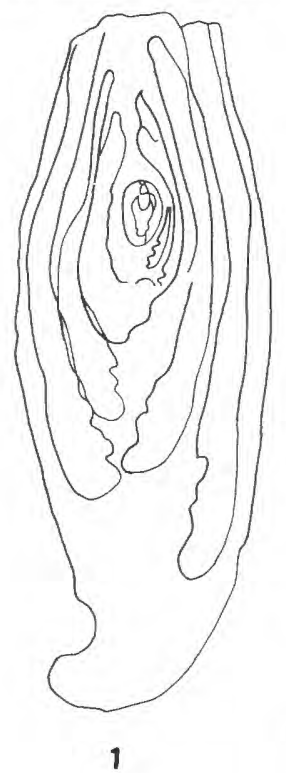

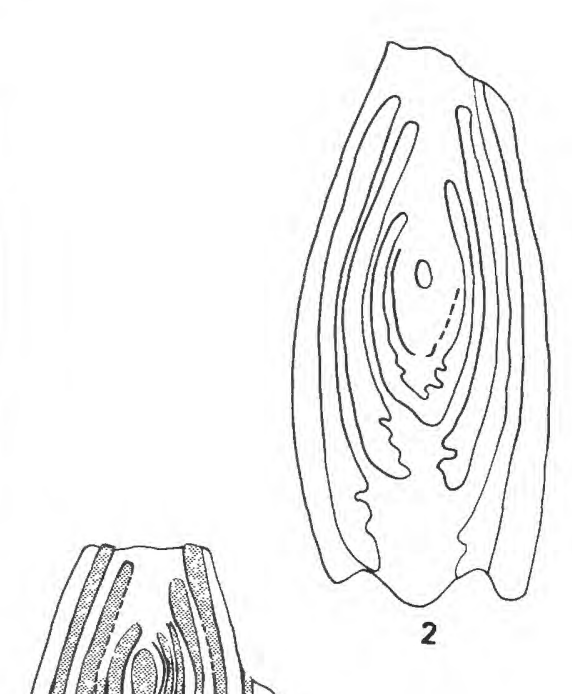
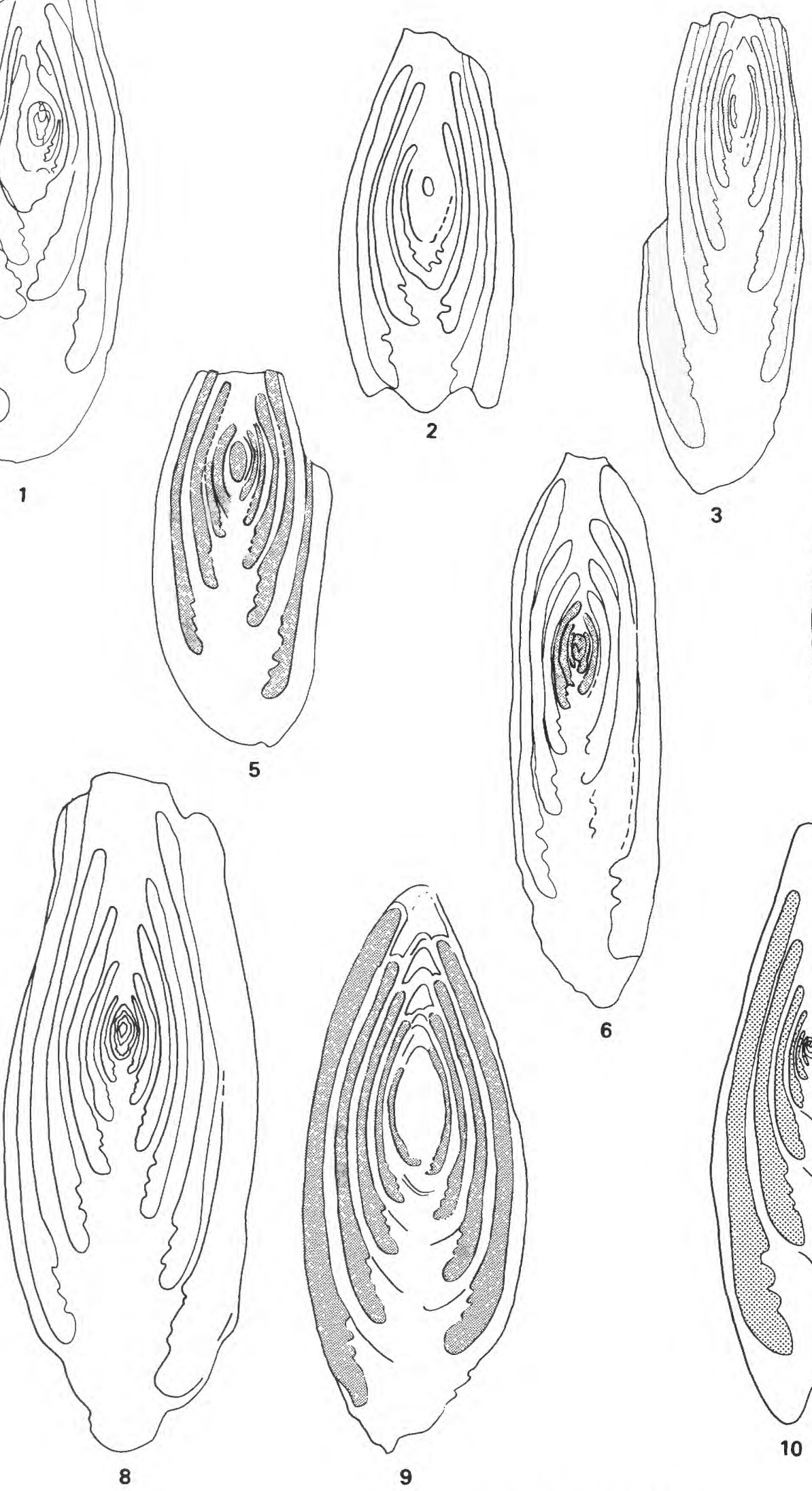


\section{PLATE 21}

Figures 1-6. Actaeonella marchmontensis Sohl and Kollmann, n. sp. (p. 71).

1. Aperture view $(\times 6)$ of a paratype from the "Titanosarcolites limestone," Marchmont inlier, Jamaica, at locality 97. USGS 30026; USNM 130668.

2. Aperture view $(\times 6)$ of a paratype from the same locality. USGS 30026; USNM 130669.

3. Aperture view $(\times 4)$ of a paratype from the same locality. USGS 30026; USNM 130670.

4. Aperture view $(\times 4)$ of the holotype from the same locality. USGS 30026; USNM 130671.

5. Aperture view $(\times 4)$ of a paratype from the Guinea Corn Formation, Central inlier, Jamaica, at locality 64 . USGS 30044; USNM 130672.

6. Aperture view $(\times 4)$ of a paratype from the "Titanosarcolites Limestone," Marchmont inlier, Jamaica, at locality 97. USGS 30026; USNM 130673.

7-12, 15. Actaeonella coquiensis Sohl and Kollmann, n. sp. (p. 70).

7. Aperture view $(\times 3)$ of a paratype from the Coamo Formation of Berryhill and Glover (1960), Central Aquirre Quadrangle, Puerto Rico, at locality 16. USGS 30358; USNM 306186.

8. Aperture view $(\times 2)$ of a paratype from the same locality. USGS 30358; USNM 306187.

9. Aperture view $(\times 2)$ of the holotype from the same locality. USGS 30358; USNM 306188 .

10. Aperture view $(\times 4)$ of a paratype from the same locality. USGS 30358; USNM 306189.

11. Aperture view $(\times 2)$ of a paratype from the same locality. USGS 30358 ; USNM 306190.

12. Aperture view $(\times 5)$ of a paratype from the same locality. USGS 30358 ; USNM 306191 .

15. Back view $(\times 5)$ of a paratype from the Coamo Formation of Berryhill and Glover (1960), which shows borings in shell. Central Aguirre Quadrangle, Puerto Rico, at locality 18. USGS 30541; USNM 306192.

13, 19-23. Actaeonella cf. A. coquiensis Sohl and Kollmann (p. 71).

13. Back view $(\times 1)$ of an incomplete specimen from the Melones Limestone, Puerto Real Quadrangle, Puerto Rico, at locality 32. USGS 30537; USNM 306193.

19. Axial section $\left(\times 1 \frac{112}{2}\right)$ of a specimen from near central Soledad, Santa Clara Province, Cuba, at locality 127. USGS 27266; USNM 306194.

20. Axial section $\left(\times 1 \frac{112}{2}\right)$ of a specimen from the same locality. USGS 27266; USNM 306195.

21-23. Axial sections $(\times 1)$ of specimens from the Melones Limestone, Puerto Real Quadrangle, Puerto Rico, at locality 32. USGS 30537; USNM 306196-306198.

14, 16-18. Actaeonella briggsi Sohl and Kollmann, n. sp. (p. 72).

14. Aperture view $(\times 3)$ of a paratype from Pozas Formation, Barranquitas Quadrangle, Puerto Rico, at locality 4. USGS 29365; USNM 306199.

16, 17. Aperture and back view $(\times 2)$ of a paratype from El Rayo Formation, San German Quadrangle, Puerto Rico, at locality 48. USGS 30354; USNM 306200.

18. Aperture view $(\times 2)$ of the holotype from the Pozas Formation, Barranquitas Quadrangle, Puerto Rico, at locality 4. USGS 29365; USNM 306201. 
GEOLOGICAL SURVEY
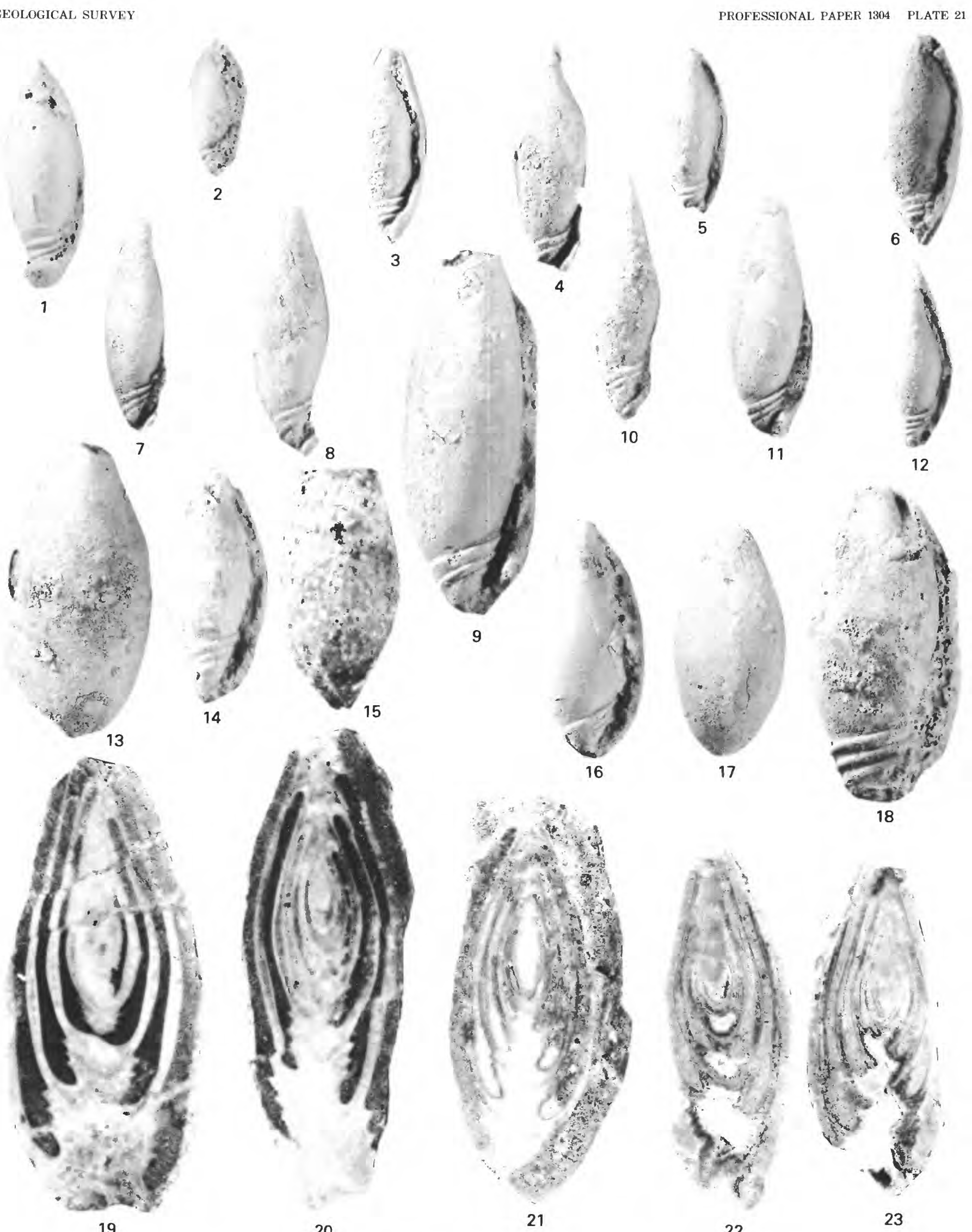

20
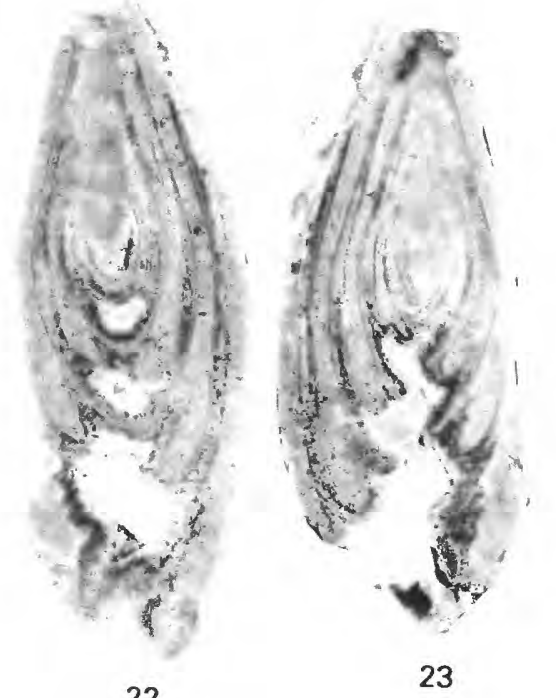

ACTAEONELLA 


\section{PLATE 22}

Figures 1, 2, 5. Actaeonella robinsoni Sohl and Kollmann, n. sp. (p. 73).

1. Aperture view $\left(\times 1 \frac{112}{2}\right)$ of a paratype from the Cardenas Formation, State of San Luis Potosi, Mexico, at locality 158. USGS 28219; USNM 306174.

2. Axial section $(\times 1)$ of a paratype from the Guinea Corn Formation, Central inlier, Jamaica, at locality 70. USGS 29988; USNM 306175 .

5. Axial section $(\times 1)$ of the holotype from the Guinea Corn Formation, Central inlier, Jamaica, at locality 69 . USGS 29987; USNM 306176.

3, 4. Actaeonella n. sp. A. (p. 73).

Axial section and aperture view $(\times 1)$ of a specimen from the Maravillas Formation, Coamo Quadrangle, Puerto Rico, at locality 19. USGS 26834; USNM 306177.

6. Actaeonella sp. (p. 74).

Axial section $\left(\times 1 \frac{1 / 2}{2}\right)$ of a specimen from the Barrancas Limestone Member of the Magueyes Formation, Barranquitas Quadrangle, Puerto Rico, at locality 12. USGS 31363; USNM 360178.

7. Actaeonella sp. $B$ (p. 74).

Aperture view $(\times 4)$ of a specimen from glacial erratic cobbles of sideritic ironstone concretions on Martha's Vineyard, Mass., at locality 131. USGS 9568; USNM 360179. 


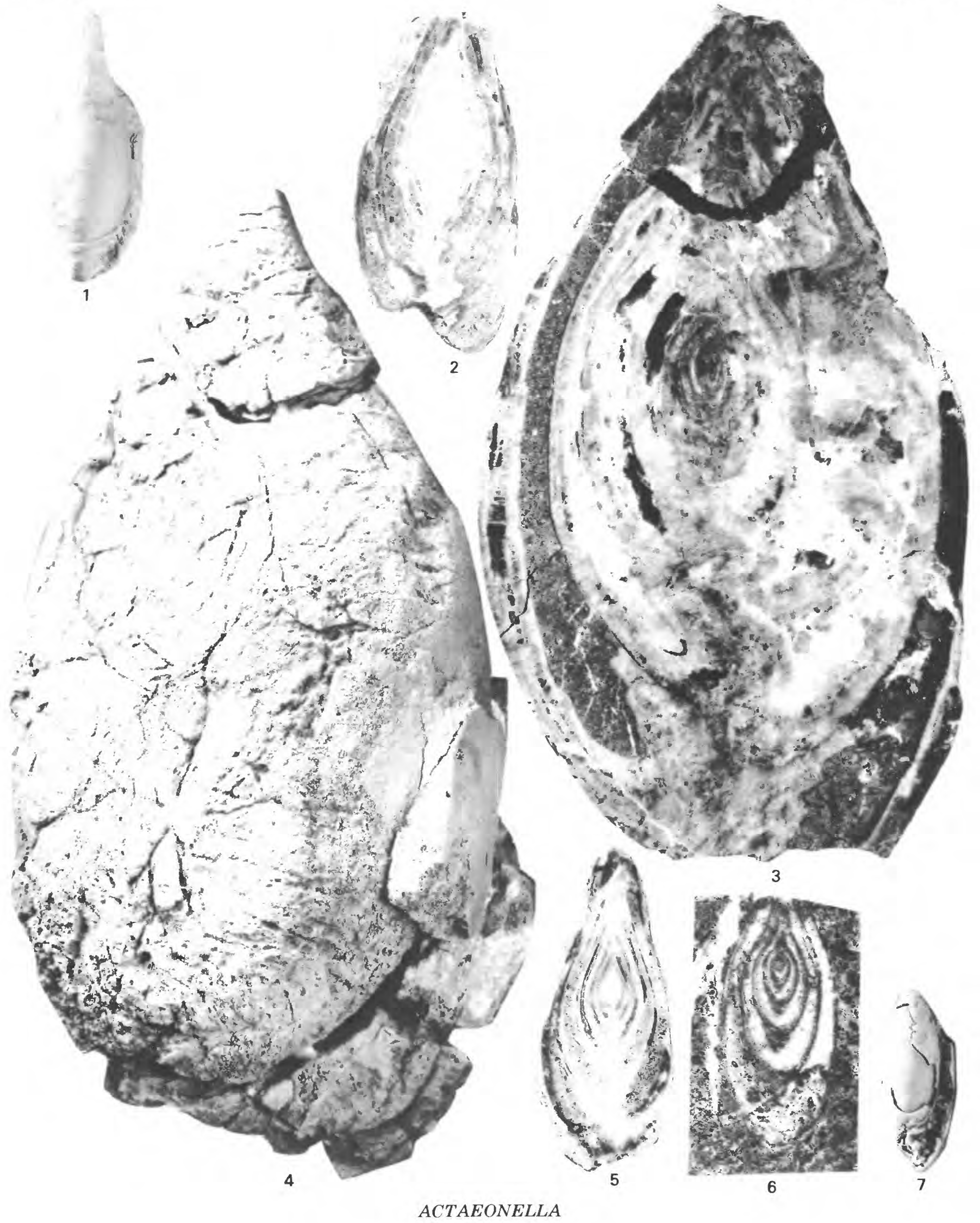




\section{PLATE 23}

Figures 1, 6. Actaeonella n. sp. A. (p. 73).

1. Axial section $(\times 1)$ of a specimen from the Maravillas Formation, Coamo Quadrangle, Puerto Rico, at locality 19. USGS 26834; USNM 306180.

6. Axial section $(\times 1)$ of a specimen from the Pozas Formation, Orocovis Quadrangle, Puerto Rico, at locality 26. USGS 30532; USNM 306181.

2-5, 7, 8. Actaeonella cubensis Sohl and Kollmann, n. sp. (p. 72).

2. Aperture view $\left(\times 1 \frac{112}{2}\right)$ of a paratype from the Habana(?) Formation, Oriente Province, Cuba, at approximately locality 125. USGS 19464; USNM 306182.

3. Aperture view $\left(\times 1 \frac{1 / 2}{2}\right)$ of the holotype from Habana(?) Formation, Oriente Province, Cuba, at locality 125 . USGS 19465; USNM 306183.

4, 5. Axial sections $(\times 3$ and $\times 6$ ) of a paratype from the same locality. USGS 19465; USNM 306184 .

7. Aperture view $(\times 2)$ of a paratype from the same locality. USGS 19465 ; USNM 306185 .

8. Aperture view $(\times 2)$ of a paratype from the same locality. USGS 19465 ; USNM 306186 . 


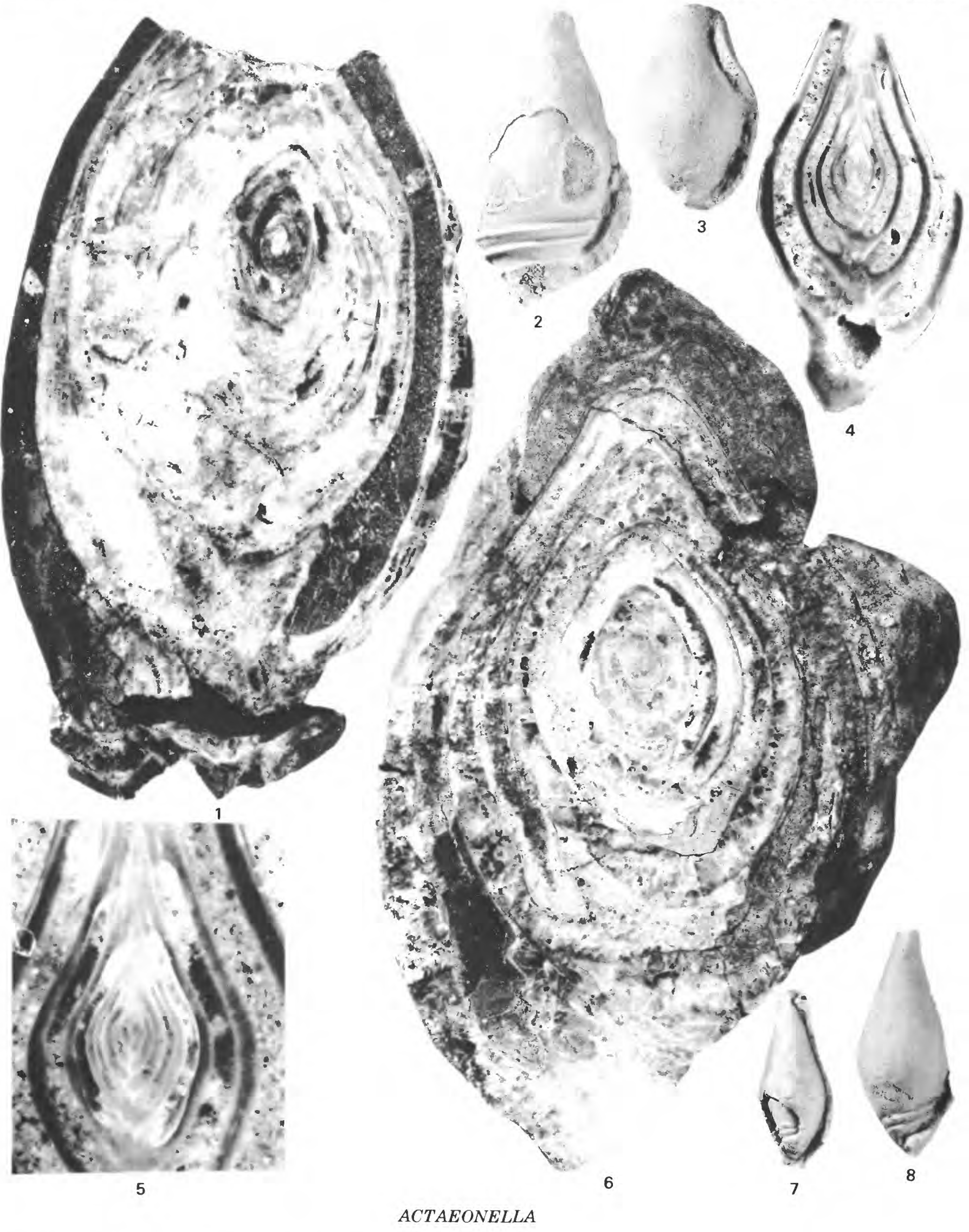

